RODRIGO MARTINS REIS

\title{
COMPORTAMENTO TENSÃO-DEFORMAÇÃO DE DOIS HORIZONTES DE UM SOLO RESIDUAL DE GNAISSE
}

Tese apresentada à Escola de Engenharia de São Carlos, da Universidade de São Paulo, como parte dos requisitos para obtenção do Título de Doutor em Geotecnia.

Orientador: Prof. Titular Orencio Monje Vilar

São Carlos

2004 
Ficha catalográfica preparada pela Seçăo de Tratamento

da Informaçăo do Serviço de Biblioteca - EESC/USP

Reis, Rodrigo Martins

Comportamento Tensão-Deformação de dois Horizontes de um

R375C Solo Residual de Gnaisse / Rodrigo Martins Reis. -

São Carlos, 2004

Tese (Doutorado)-Escola de.Engenharia de Săo

Carlos-Universidade de São Paulo, 2004

Área: Geotecnia

Orientador: Prof. Dr. Orencio Monje Vilar

1. Solos residuais. 2. Resistência ao cisalhamento. 3. Anisotropia. 4. Solos não Saturados. 5. Curva de Plastificação. I. Título. 
Candidato: Engenheiro RODRIGO MARTINS REIS

Tese defendida e julgada em 06-08-2004 perante a Comissão Julgadora:

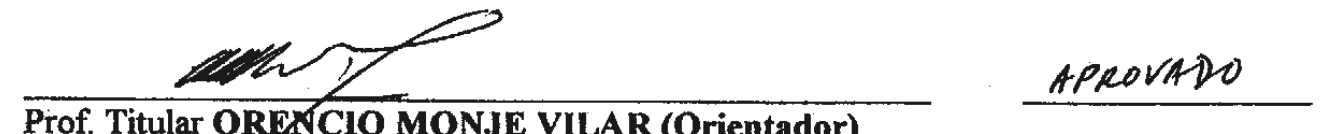

(Escola de Engenharia de São Carlos/USP)

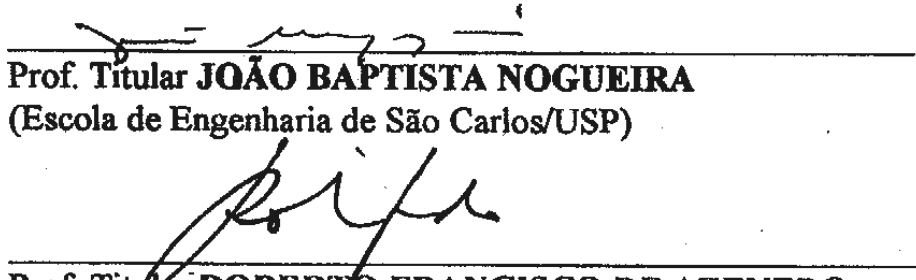

$4 \rightarrow 20 \times x+0$

Prof. Tit thar ROBERT6 FRANCISCO DE AZEVEDO

(Universidade Federal de Viçosa/UFV)

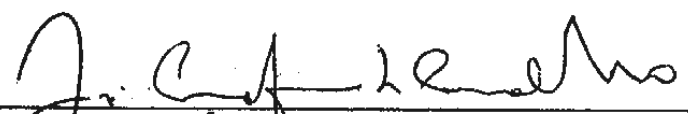

Prof/Titular JOSÉ CA MAPUM DE CARVALHO

(Upiverpidade de Brasilia/UnB)

\section{Alux BParwixa}

Amovato

\section{Prof. Associado ALEXANDRE BENETTI PARREIRA}

(Escola de Engenharia de São Carlos/USP)

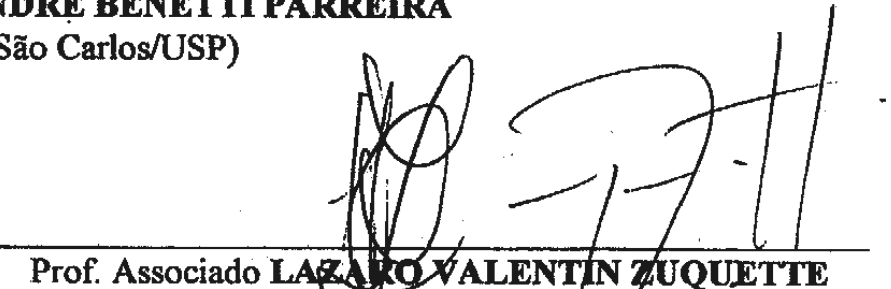

Coordenador do Programg de Pós-Graquaqão em Geotecnia

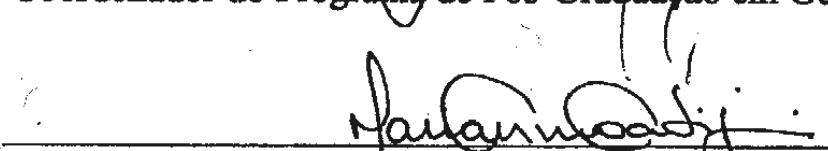

Profa. Titular MARIA DO CARMO CALIJURI

Presidente da Comissão de Pós-Graduação da EESC 
Aos meus pais e à minha esposa, pela paciência e pelo amor. 


\section{AGRADECIMENTOS}

Um Sincero e especial agradecimento ao orientador deste trabalho, Prof. Dr. Orencio Monje Vilar, sem a colaboração de quem fatalmente não teria sido possível realizar esta pesquisa. Pela colaboração, pela amizade, pelo empenho, pelo constante estímulo e pela paciência na realização deste trabalho, o meu muito obrigado.

A todos os professores do Departamento de Geotecnia da Escola de Engenharia de São Carlos (EESC) pelos conhecimentos transmitidos e pela amizade.

Ao coordenador do Curso de Pós-Graduação em Geotecnia Lázaro Valentim Zuquette, por sua dedicação aos assuntos da pós-graduação e por sempre estar disposto a ajudar.

Aos técnicos do Departamento de Geotecnia da EESC - USP, em especial a José Luís e Oscar.

A todos os colegas de pós-graduação, pela amizade e pelos momentos de descontração.

A CAPES pelo apoio financeiro.

Aos Professores Carlos Ernesto Schaffer e Maurício Paulo Ferreira Fontes, do Departamento de Solos da Universidade Federal de Viçosa, pela valiosa colaboração, respectivamente, nas análises de caracterização microestrutural e mineralógica das amostras de solos utilizadas neste trabalho.

Ao Professor Roberto Francisco de Azevedo, do Departamento de Engenharia Civil da Universidade Federal de Viçosa, pela amizade e constante apoio e estímulo nesta minha caminhada.

Aos meus pais, Múcio Silva Reis e Silvia Maria Martins Reis, aos meus irmãos, pelo grande amor e pelo apoio irrestrito.

A minha esposa, Nora, pelo amor, apoio e paciência. 


\section{SUMÁRIO}

LISTA DE FIGURAS i

LISTA DE TABELAS ix

LISTA DE SÍMBOLOS - xi

RESUMO Xiii

ABSTRACT xiv

1 INTRODUÇÃO 1

2 REVISÃO BIBLIOGRÁFICA 4

2.1 Gênese de solos residuais $\quad 4$

2.1.1 Generalidades 4

2.1.2 Processos intempéricos 7

2.1.3 Produtos do intemperismo 8

2.1.4 Intemperismo tropical 9

2.1.5 Perfis de alterações de solos residuais 13

2.1.5.1 Introdução 13

2.1.5.2 Classificações para o perfil de Alteração 15

2.1.5.3 Perfis típicos de alteração 18

2.1.5.4 Caracterização dos horizontes do perfil de Alteração 20

2.2. Fatores que interferem no comportamento tensão-deformação e resistência de solos residuais $\quad 22$

2.2.1 Introdução 22

2.2.2 Estrutura cimentada 25

2.2.2.1 Introdução 25

2.2.2.2 Aspectos de reologia dos solos estruturados 28

2.2.2.3 Identificação da estrutura cimentada 36 
2.2.2.4 Fatores que pertubam a estrutura cimentada

2.2.3 Anisotropia

2.2.3.1 Introdução 42

2.2.3.2 Alguns trabalhos realizados $\quad 43$

2.2.4 Condição não Saturada

2.2.4.1 Potencial de água no solo $\quad 53$

2.2.4.1.1 Introdução 53

2.2.4.1.2 Conceituação geral 53

2.2.4.1.3 Potencial da Água dos solos não saturados 55

2.2.4.2 Curva de Retenção da água do solo 58

2.2.4.3 Características de tensão versus deformação 60

2.2.4.3.1 Cisalhamento 60

$\begin{array}{ll}\text { 2.2.4.3.2 Adensamento } & 61\end{array}$

2.2.4.3.3 Análise de solos não saturados com base nas
variáveis de estado

2.2.4.4 Resistência 65

2.2.4.4.1 Introdução $\quad 65$

2.2.4.4.2 Resistência ao cisalhamento não saturada 65

2.2.4.4.3 Técnica de Translação de eixos (HILF, 1956) 69

2.2.5 Alguns trabalhos desenvolvidos ao longo de um perfil de solo residual

2.3 Curvas de plastificação de Modelos baseados na teoria dos Estados Críticos

2.3.1 Critérios para a identificação da Tensão de Escoamento 73

2.3.2 Modelo Cam-Clay $\quad 75$

$\begin{array}{ll}\text { 2.3.3 } \text { Modelo de Alonso et al (1990) } & 77\end{array}$

\section{MATERIAIS E MÉTODOS}

3.1 Características gerais da região de Viçosa 80

$\begin{array}{ll}3.1 .1 \text { Localização geográfica } & 80\end{array}$

$\begin{array}{ll}\text { 3.1.2 Dados climatológicos } & 80\end{array}$

3.1.3 Geologia 81

3.1.4 Geomorfologia 82

3.1.5 Pedologia 83 
3.1.5.1 Latossolo Vermelho-Amarelo (LV)

3.1.5.2 Latossolo Vermelho-Amarelo Variação Uma (LVU) 84

3.1.5.3 Cambissolo (CL) 84

3.1.5.4 Podzólico Vermelho-Amarelo (PV) 85

3.1.5.5 Podzólico Vermelho-Amarelo com B Bruno micáceo $\begin{array}{ll}\text { (PVB) } & 85\end{array}$

3.1.5.6 Cambissolo Latossólico (CL) 85

3.1.5.7 Solos Hidromórficos (HI) 86

3.2 Perfil de solo escolhido 86

3.2.1 Latossolo Vermelho-Amarelo 88

$\begin{array}{ll}\text { 3.2.2 Solo sprolítico (residual jovem) } & 89\end{array}$

$\begin{array}{ll}3.3 \text { Métodos } & 90\end{array}$

$\begin{array}{ll}\text { 3.3.1 Metodologia de campo } & 90\end{array}$

3.3.2 Metodologia de Laboratório 91

3.3.2.1 Ensaios de caracterização $\quad 91$

3.3.2.1.1 Caracterização Geotécnica $\quad 91$

3.3.2.1.2 Análise Mineralógica $\quad 91$

3.3.2.1.3 Caracterização MCT (Miniatura, Compactado,

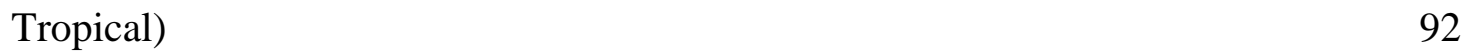

3.3.2.1.4 Análise Porosimétrica $\quad 92$

3.3.2.1.5 Análise Micromorfológica $\quad 92$

3.3.2.2 Ensaios triaxiais 93

3.3.2.2.1 Ensaios em amostras saturadas 93

3.3.2.2.2 Ensaios em amostras não saturadas 98

4 RESULTADOS 100

$\begin{array}{ll}\text { 4.1 Ensaios de Caracterização } & 100\end{array}$

$\begin{array}{ll}\text { 4.1.1 Caracterização Geotécnica } & 100\end{array}$

$\begin{array}{ll}\text { 4.1.2 Ensaios de Caracterização Mineralógica } & 101\end{array}$

4.1.3 Ensaios de Porosimetria 103

4.1.4 Classificação MCT 105

$\begin{array}{ll}\text { 4.1.5 Curva Característica } & 107\end{array}$

$\begin{array}{ll}\text { 4.1.6 Lâminas Delgadas } & 108\end{array}$ 
4.2.1 Ensaios drenados em amostras saturadas por contrapressão

4.2.2 Ensaios em amostras não saturadas

4.2.2.1 Ensaios com sucção matricial controlada

4.2.2.2 Amostras não saturadas secas ao ar

5 ANÁLISES DOS RESULTADOS

5.1 Ensaios de caracterização

5.1.1 Classificação MCT (Miniatura, Compactado, Tropical)

5.1.2 Caracterização Mineralógica

5.1.3 Caracterização Micromorfológica

5.1.3.1 Solo Maduro (Latossolo Vermelho - Amarelo)

5.1.3.2 Solo Jovem (solo saprolítico)

5.1.3.3 Comparação entre os dois solo

5.2.1 Discussão das Curvas Tensão deformação obtidas dos ensaios realizados

5.2.1.1 Amostras saturadas

5.2.1.2 Amostras não saturadas com controle de sucção

5.2.2 Análise da resistência e deformabilidade em condições saturadas

5.2.2.1 Análise da resistência

5.2.2.2 Análise da deformabilidade

5.2.3 Análise da resistência em condições não saturadas com imposição e controle de sucção

5.2.4 Curva de plastificação

5.2.4.1 Determinação do Ponto de Cedência (escoamento) 163

5.2.4.2 Definição dos parâmetros elásticos 164

5.2.4.3 Parâmetro de encruamento 165

$\begin{array}{ll}\text { 5.2.4.4 Solo jovem (saturado) } & 168\end{array}$

$\begin{array}{ll}\text { 5.2.4.5 Solo não saturado com sucção controlada } & 170\end{array}$ 
6 CONCLUSÕES

7 REFERÊNCIAS

179

8 NORMAS TÉCNICAS

193

9 ANEXOS 


\section{LISTA DE FIGURAS}

\section{Capítulo 2}

Figura 2.1 Formação dos solos (Esquemático, modificado), (NOGUEIRA, 1988).

Figura 2.2 Perfil possível de solos tropicais (CRUZ, 1987).

Figura 2.3 Modelos Estruturais (CRUZ, 1987).

Figura 2.4 Diagrama esquemático de um perfil típico de solo residual (LITTLE 1969).

Figura 2.5 Mudanças ocorrentes no perfil de intemperismo (BLIGHT, 1997).

Figura 2.6 Curvas típicas obtidas de ensaios oedométricos em solos brasileiros (VARGAS, 1953).

Figura 2.7 Tensão aparente de pré-adensamento (VARGAS, 1973); a) Observada em oedômetro; (b) influência na resistência drenada em cisalhamento direto.

Figura 2.8 Testes triaxiais drenados em solo residual de basalto (VAUGHAN, 1988).

Figura 2.9 Curva de compressão confinada para uma argila sedimentar cimentada (SANGREY, 1972).

Figura 2.10 Curva de compressão triaxial executada em argilas sedimentares cimentadas (SANGREY, 1972).

Figura 2.11 Curva q versus $\mathrm{p}$ de testes de compressão triaxial, mostrando a cedência (SANGREY, 1972).

Figura 2.12 Superfície de escoamento obtidas a partir de ensaios triaxiais em amostras indeformadas de argila. a) Superfícies de escoamento no espaço q; p' e b) Superfícies de escoamento normalizadas pela tensão vertical de campo (GRANHAN et al, 1983).

Figura 2.13 Cedência (escoamento) observada em ensaios triaxiais realizados com solos residuais: a) solo residual de gnaisse (SANDRONI, 1981); b) Solo residual de basalto (VAUGHAN et al, 1988).

Figura 2.14 Curvas de escoamento para solos estruturados: (a) anisotropia em argilas e (b) isotropia em algumas rochas moles e solos residuais (LEROUEIL \& VAUGHAN, 1990).

Figura 2.15 Curva de compressão oedométrica de um solo residual de basalto a partir do estado inicial mais fofo possível (solo desestruturado) 
relacionada ao índice de vazios in - situ (VAUGHAN, 1985).

Figura 2.16 Resultados de testes oedométricos numa argila vermelha nos estados indeformado e remoldado (WESLEY, 1990).

Figura 2.17 Relação entre pressão de terra e pressão virtual de préadensamento num solo residual de diabásico (MACCARINI, 1989).

Figura 2.18 Resultados dos ensaios de cisalhamento direto em solo gnáissico (COSTA FILHO \& DE CAMPOS, 1991).

Figura 2.19 Resultados dos ensaios triaxiais em amostras saturadas de solo gnáissico (COSTA FILHO \& DE CAMPOS, 1991).

Figura 2.20 Resultados dos ensaios oedométricos feitos em amostras submersas de solo gnáissico (COSTA FILHO \& DE CAMPOS, 1991).

Figura 2.21 Gráfico pxq, na ruptura, dos ensaios realizados (REIS \& AZEVEDO, 1998).

Figura 2.22 Esquema ilustrativo da definição de potencial total da água no solo.

Figura 2.23 Água de um solo não saturado sujeita à capilaridade e adsorção, que combinados produzem um potencial matricial (HILLEL, 1971).

Figura 2.24 Esquema ilustrativo da definição de sucção: corresponde $\mathrm{a}_{\mathrm{a}}-\mathrm{u}_{\mathrm{w}}$ de sorte a não haver fluxo através da membrana semi-permeável.

Figura 2.25 Representação dos conceitos de sucção matricial, osmótica e total. 57

Figura 2.26 Curva característica (FREDLUND et al., 1994).

Figura 2.27 Curva ilustrando a tensão versus deformação em função da sucção.

Figura 2.28 Gráfico ilustrando o comportamento índice de vazios versus tensão aplicada em função da sucção.

Figura 2.29 Comportamento de solo não-saturado, mostrando inchamento e colapso (GENS, 1995).

Figura 2.30 Estado de tensões para as partículas sólidas e a membrana contrátil de um elemento de solo não saturado (FREDLUND \& MORGENSTERN, 1977).

Figura 2.31 Tensores representantes do estado de tensões do solo 
Figura 2.32 (a) Trajetórias de tensões no espaço q; p’, (b) teste de compressão isotrópica (1), (c) teste de compressão confinada (2) e (d) teste de compressão triaxial não drenado (3), (WOOD, 1992).

Figura 2.33 (a) Caminhos de tensões para carregamento $\mathrm{P}$ e sucção (S): constante; (b) Superfície de escoamento SI e LC (ALONSO et al., 1987).

Figura 2.34 Superfícies de escoamento nos espaços: (a) (p, q) e (b) (p, s), (ALONSO et al.,1990).

\section{Capítulo 3}

Figura 3.1 Esquema de conformação típica da vertente de Viçosa-MG, assinalando-se seus segmentos (Resende, 1971).

Figura 3.2 Perfil de solo estudado

Figura 3.3 (a e b) Croquis da vista frontal e lateral do perfil.

Figura 3.4 Latossolo Vermelho-Amarelo estudado

Figura 3.5 Solo saprolítico estudado

Figura 3.6 Equipamento triaxial convencional utilizado para os ensaios saturados.

Figura 3.7 Direções adotadas, em relação ao bandamento, na moldagem dos corpos de prova para o solo residual jovem.

Figura 3.8 Disposição geral dos componentes da prensa triaxial do tipo Bishop Wesley servo controlada.

Figura 3.9 Transdutores de deslocamento de efeito Hall: (a) Desmontados; (b) Montados sobre o corpo de prova.

Figura 3.10 Representação esquemática da prensa Bishop Wesley utilizada.

Figura 3.11 Trajetória de tensões adotadas nos ensaios com tensão controlada realizados na célula do tipo Bishop Wesley.

Figura 3.12 Câmaras para instalação da sucção matricial nos ensaios com sucção controlada.

\section{Capítulo 4}

Figura 4.1 Curvas granulométricas dos solos estudados. 
Figura 4.2 Difratogramas do solo residual maduro.

Figura 4.3 Difratograma expandido da fração argila do solo maduro.

Figura 4.4 Difratograma do solo residual jovem.

Figura 4.5 Difratograma expandido da fração argila do solo jovem.

Figura 4.6 Pressão de mercúrio (psi) versus volume acumulado de mercúrio (ml/g), (solo maduro)

Figura 4.7 Diâmetro dos proros (micrometro) versus volume acumulado de mercúrio (ml/g), (solo maduro).

Figura 4.8 Diâmetro dos poros versus log diferencial do volume de mercúrio (ml/g), (solo maduro).

Figura 4.9 Pressão de mercúrio (Psi) versus volume acumulado de mercúrio (ml/g), (solo jovem).

Figura 4.10 Diâmetro dos poros (micrometro) versus volume acumulado de mercúrio (ml/g), (solo jovem).

Figura 4.11 Diâmetro dos poros versus log diferencial do volume de mercúrio (ml/g) (solo jovem).

Figura 4.12 Curvas de Afundamento (mm) em função do número de golpes (determinação de c').

Figura 4.13 Curvas de compactação com o número de golpes para cada teor de umidade (determinação de d').

Figura 4.14 Curva de Perda de Massa por Imersão em função do mini-MCV (determinação de PI).

Figura 4.15 Curvas de Afundamento (mm) em função do número de golpes (determinação de c').

Figura 4.16 Curvas de compactação com o número de golpes para cada teor de umidade (determinação de d').

Figura 4.17 Curva de perda de massa por imersão em função do Mini-MCV (determinação de PI).

Figura 4.18 Classificação MCT para os dois solos

Figura 4.19 Curva característica obtida para os dois solos 
Figura 4.20 Amostras indeformada do solo maduro observada ao microscópio ótico.

Figura 4.21 Lâmina Delgada do solo maduro revelando forte microestruturação granular, tonalidades vermelho-amarelas, abundantes carvões, nódulos ferruginosos e vazios interligados. Os teores de ferro cimentante são elevados.

Figura 4.22 Amostra do solo maduro evidenciando certa soldagem (coalescência) dos microagregados de forma ovóide, na parte mais compacta da amostra.

Figura 4.23 Fotomicrografia da amostra do solo maduro mostrando a ligação entre os diversos blocos de microagregados.

Figura 4.24 Figura do solo saprolítico (jovem) mostrando detalhes da organização estrutural dos pseudomorfos de biotita orientados em relação ao plano horizontal (Luz plana).

Figura 4.25 Figura do solo saprolítico (jovem) mostrando detalhes da organização estrutural dos pseudomorfos de biotita (Luz polarizada).

Figura 4.26 Resultados dos ensaios CIDsat, solo jovem, para a direção vertical: (a) $\left(\sigma_{1}-\sigma_{3}\right) \times \varepsilon_{\text {axial }}$, (b) $\varepsilon_{\mathrm{v}} \mathrm{x} \varepsilon_{\text {axial }}$.

Figura 4.27 Resultados dos ensaios CIDsat, solo jovem, para a direção paralela ao bandamento: (a) $\left(\sigma_{1}-\sigma_{3}\right) \times \varepsilon_{\text {axial }}$, (b) $\varepsilon_{\mathrm{v}} \times \varepsilon_{\text {axial }}$.

Figura 4.28 Resultados dos ensaios CIDsat, solo jovem, para a direção perpendicular ao bandamento: (a) $\left(\sigma_{1}-\sigma_{3}\right) \times \varepsilon_{\text {axial }}$, (b) $\varepsilon_{\mathrm{v}} \times \varepsilon_{\text {axial }}$.

Figura 4.29 Resultados dos ensaios CIDsat, solo maduro, para a direção vertical: (a) $\left(\sigma_{1}-\sigma_{3}\right) \times \varepsilon_{\text {axial }}$, (b) $\varepsilon_{\mathrm{v}} \times \varepsilon_{\text {axial }}$.

Figura 4.30 Resultados dos ensaios CIDsat, solo maduro, para a direção horizontal: (a) $\left(\sigma_{1}-\sigma_{3}\right) \times \varepsilon_{\text {axial }}$, (b) $\varepsilon_{\mathrm{v}} \times \varepsilon_{\text {axial }}$

Figura 4.31 Resultados dos ensaios CIDsat, solo maduro, para a direção de $45^{0}$ : (a) $\left(\sigma_{1}-\sigma_{3}\right) \times \varepsilon_{\text {axial }}$, (b) $\varepsilon_{\mathrm{v}} \times \varepsilon_{\text {axial }}$.

Figura 4.32 Resultados dos ensaios em trajetórias diferentes da convencional, realizados na célula Bishop Wesley, para o solo jovem: (a) $\left(\sigma_{1^{-}}\right.$ $\left.\sigma_{3}\right) \times \varepsilon_{\text {axial }}$, (b) $\varepsilon_{\mathrm{v}} \times \varepsilon_{\text {axial }}$.

Figura 4.33 Resultado dos ensaios de compressão hidrostática realizados no solo jovem.

Figura 4.34 Resultados dos ensaios de compressão hidrostática realizados no 
solo maduro

Figura 4.35 Resultados dos ensaios CID, solo jovem, para $\mathrm{u}_{\mathrm{a}}-\mathrm{u}_{\mathrm{w}}=40 \mathrm{kPa}$ : (a) 119 $\left(\sigma_{1}-\sigma_{3}\right) \times \varepsilon_{\text {axial }},(\mathrm{b}) \varepsilon_{\mathrm{v}} \times \varepsilon_{\text {axial }}$.

Figura 4.36 Resultados dos ensaios CID, solo jovem, para $\mathrm{u}_{\mathrm{a}}-\mathrm{u}_{\mathrm{w}}=80 \mathrm{kPa}$ : (a) $\left(\sigma_{1}-\sigma_{3}\right) \times \varepsilon_{\text {axial }},(\mathrm{b}) \varepsilon_{\mathrm{v}} \times \varepsilon_{\text {axial }}$.

Figura 4.37 Resultados dos ensaios CID, solo jovem, para $\mathrm{u}_{\mathrm{a}}-\mathrm{u}_{\mathrm{w}}=160 \mathrm{kPa}$ : (a) $\left(\sigma_{1}-\sigma_{3}\right) \times \varepsilon_{\text {axial }}$, (b) $\varepsilon_{\mathrm{v}} \times \varepsilon_{\text {axial. }}$.

Figura 4.38 Resultados dos ensaios CID, solo jovem, para $\mathrm{u}_{\mathrm{a}}-\mathrm{u}_{\mathrm{w}}=320 \mathrm{kPa}$ : (a) $\left(\sigma_{1}-\sigma_{3}\right) \times \varepsilon_{\text {axial }}$, (b) $\varepsilon_{\mathrm{v}} \times \varepsilon_{\text {axial }}$.

Figura 4.39 Resultados dos ensaios CID, solo maduro, para $\mathrm{u}_{\mathrm{a}}-\mathrm{u}_{\mathrm{w}}=40 \mathrm{kPa}$ :

(a) $\left(\sigma_{1}-\sigma_{3}\right) \times \varepsilon_{\text {axial }}$, (b) $\varepsilon_{\mathrm{v}} \times \varepsilon_{\text {axial }}$.

Figura 4.40 Resultados dos ensaios CID, solo maduro, para $\mathrm{u}_{\mathrm{a}}-\mathrm{u}_{\mathrm{w}}=80 \mathrm{kPa}$ : (a) $\left(\sigma_{1}-\sigma_{3}\right) \times \varepsilon_{\text {axial }}$, (b) $\varepsilon_{\mathrm{v}} \times \varepsilon_{\text {axial }}$.

Figura 4.41 Resultados dos ensaios CID, solo maduro, para $\mathrm{u}_{\mathrm{a}}-\mathrm{u}_{\mathrm{w}}=160 \mathrm{kPa}$ : (a) $\left(\sigma_{1}-\sigma_{3}\right) \times \varepsilon_{\text {axial }}$, (b) $\varepsilon_{\mathrm{v}} \times \varepsilon_{\text {axial }}$.

Figura 4.42 Resultados dos ensaios CID, solo maduro, para $\mathrm{u}_{\mathrm{a}}-\mathrm{u}_{\mathrm{w}}=320 \mathrm{kPa}$ : (a) $\left(\sigma_{1}-\sigma_{3}\right) \times \varepsilon_{\text {axial }},(\mathrm{b}) \varepsilon_{\mathrm{v}} \times \varepsilon_{\text {axial }}$.

Figura 4.43 Resultados dos ensaios de compressão hidrostática, para diferentes sucções, realizadas no solo jovem.

Figura 4.44 Resultados dos ensaios de compressão hidrostática, para 127 diferentes sucções, realizadas no solo maduro.

Figura 4.45 Resultados dos ensaios CID, solo jovem, para amostras secas ao 128 ar: (a) $\left(\sigma_{1}-\sigma_{3}\right) \times \varepsilon_{\text {axial }}$, (b) $\varepsilon_{\mathrm{v}} \times \varepsilon_{\text {axial }}$.

\section{Capítulo 5}

Figura 5.1 Efeito da cimentação: (a) curvas tensão-deformação; (b) curvas de 138 cedência.

Figura 5.2 Efeito da sucção na curva tensão versus deformação e deformação axial versus volumétrica, solo jovem, para tensão confinante igual a $50 \mathrm{kPa}$.

Figura 5.3 Efeito da sucção na curva tensão versus deformação e deformação axial versus volumétrica, solo jovem, para tensão confinante igual a $200 \mathrm{kPa}$.

Figura 5.4 Efeito da sucção na curva tensão versus deformação e deformação 
axial versus volumétrica, solo maduro, para tensão confinante igual a $50 \mathrm{kPa}$.

Figura 5.5 Efeito da sucção na curva tensão versus deformação e deformação axial versus volumétrica, solo maduro, para tensão confinante igual a $200 \mathrm{kPa}$.

Figura 5.6 Envoltória de ruptura do solo maduro considerando o efeito da direção de carregamento.

Figura 5.7 Envoltória de ruptura do solo jovem, considerando o efeito da direção de carregamento.

Figura 5.8 Envoltória de resistência para diferentes níveis de deformação (direção vertical).

Figura 5.9 Envoltória de resistência para diferentes níveis de deformação (direção paralela).

Figura 5.10 Variação do ângulo de atrito e da coesão em função do nível de deformação, para duas direções de carregamento.

Figura 5.11 Variação do módulo de elasticidade com a deformação axial, para diferentes tensões confinantes (jovem - direção vertical).

Figura 5.12 Variação de $\mathrm{E} / \sigma_{3}$ com a deformação axial, para diferentes tensões confinantes (jovem - direção vertical).

Figura 5.13 Variação do módulo de elasticidade com a deformação axial, para diferentes tensões confinantes (jovem - direção paralela).

Figura 5.14 Variação de $\mathrm{E} / \sigma_{3}$ com a deformação axial, para diferentes tensões confinantes (jovem - direção paralela).

Figura 5.15 Variação do módulo de elasticidade com a deformação axial, para diferentes tensões confinantes (jovem - direção perpendicular).

Figura 5.16 Variação de $\mathrm{E} / \sigma_{3}$ com a deformação axial, para diferentes tensões confinantes (jovem - direção perpendicular).

Figura 5.17 Envoltórias de resistência obtidas para as sucções ensaiadas (solo jovem).

Figura 5.18 Envoltórias de resistência obtidas para as sucções ensaiadas (solo maduro).

Figura 5.19 Variação da coesão em função da sucção matricial (solo jovem).

Figura 5.20 Variação da coesão em função da sucção matricial (solo maduro). 
Figura 5.21 Relação hiperbólica entre sucção $\left(\psi=\mathrm{u}_{\mathrm{a}}-\mathrm{u}_{\mathrm{w}}\right)$ e coesão, utilizada para a obtenção dos parâmetros, a e b da previsão.

Figura 5.22 Previsão da variação da coesão em função da sucção para o solo residual jovem.

Figura 5.23 Previsão da variação da coesão em função da sucção para o solo 161 residual maduro.

Figura 5.24 Previsão da envoltória de resistência não saturada através de 162 corpos de provas saturados e secos ao ar.

Figura 5.25 Definição do ponto de escoamento do ensaio de compressão hidrostática, segundo Pacheco Silva.

Figura 5.26 Definição do ponto de escoamento do ensaio de compressão hidrostática, segundo o procedimento de Grahan et al. (1983).

Figura 5.27 Definição das deformações axiais, elásticas e plásticas, ao longo da curva tensão deformação.

Figura 5.28 Tipos possíveis de deformações volumétricas, plásticas encontradas nos ensaios realizados: a) compressão; b) expansão.

Figura 5.29 Ajuste da equação 2.12 (Cam Clay modificado), aos dados experimentais.

Figura 5.30 Contornos de trabalho plásticos obtidos em ensaios realizados em amostras saturadas.

Figura 5.31 Pontos de escoamento obtidos e ajustados pela equação 2.14, para os ensaios realizados com sucção igual a $80 \mathrm{kPa}$.

Figura 5.32 Variação da curva de plastificação com a sucção.

Figura 5.33 Superfície $\mathrm{P}_{\mathrm{s}}$ (s) prevista e experimental juntamente com a superfície LC. 
LISTA DE TABELAS

\section{Capítulo 2}

Tabela 2.1 Variações típicas no índice de vazios in-situ em solos residuais brasileiros (SANDRONI, 1985).

Tabela 2.2 Espessuras de Perfis de Alteração (SOWERS, 1963).

Tabela 2.3 Índice de vazios inicial, coesão e ângulo de atrito (MACCARINI, 1980).

Tabela 2.4 Parâmetros de resistência ao cisalhamento de solos residuais jovens derivados de rochas metamórficas (COSTA FILHO ET AL, 1989).

Tabela 2.5 Valores de módulo de Young para carregamento nas direções x, y e z (REIS \& AZEVEDO, 1998).

Tabela 2.6 Resultados de ensaios do tipo convencional realizados no triaxial cúbico (ALEIXO, 1998).

\section{Capítulo 4}

Tabela 4.1 Resultados dos ensaios de caracterização geotécnica realizados.

\section{Capítulo 5}

Tabela 5.1 Índices classificatórios e classes MCT.

Tabela 5.2 Parâmetros de resistência efetivos dos solos ensaiados (triaxial convencional).

Tabela 5.3 Valores de coesão e ângulo de atrito, para diferentes níveis de deformação axial (direção vertical).

Tabela 5.4 Valores de coesão e ângulo de atrito para diferentes níveis de deformação axial (direção paralela).

Tabela 5.5 Efeito da direção de carregamento na deformabilidade.

Tabela 5.6 Módulos de elasticidade para diferentes direções de carregamento e tensões confinantes, em diferentes níveis de deformação axial. 
Tabela 5.7 Valores de c e $\varnothing$ para as diferentes sucções adotadas nos ensaios.

Tabela 5.8 Valores adotados no ajuste da função hiperbólica aos dados experimentais.

Tabela 5.9 Valores adotados na previsão da envoltória da sucção versus coesão.

Tabela 5.10 Valores das constantes usadas na previsão da envoltória de resistência não saturada.

Tabela 5.11 Valores de $\mathrm{p}_{\mathrm{s}}$ e de $\mathrm{p}_{\mathrm{o}}$ obtidos, conforme a Figura 5.29, através do ajuste da equação 2.14 aos dados experimentais.

Tabela 5.12 Valores de $\mathrm{p}_{\mathrm{s}}$ previstos pela equação 5.21 . 


\section{LISTA DE SÍMBOLOS}

\section{Símbolos do alfabeto latino}

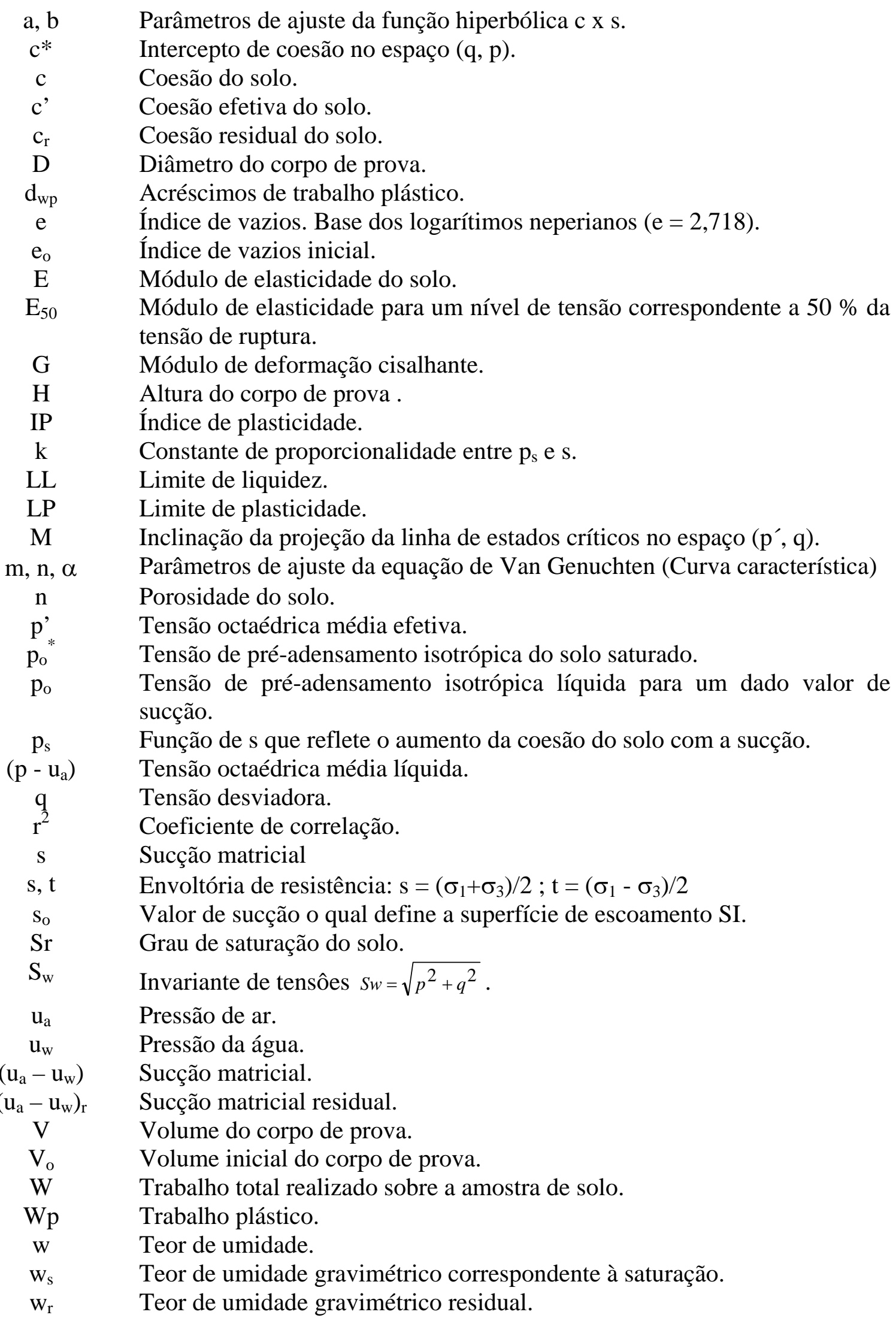




\section{Símbolos do alfabeto Grego}

$\chi \quad$ Parâmetro que depende do grau de saturação do solo, utilizado na equação de Tensão efetiva de Bishop et al. (1960).

$\varepsilon_{\mathrm{a}}$
$\varepsilon_{1}{ }^{\mathrm{t}}, \varepsilon_{1}{ }^{\mathrm{e}}, \varepsilon_{1}{ }^{\mathrm{p}}$
$\varepsilon_{3}{ }^{\mathrm{t}}, \varepsilon_{3}{ }^{\mathrm{e}}, \varepsilon_{3}{ }^{\mathrm{p}}$
$\mathrm{d} \varepsilon_{1}{ }^{\mathrm{t}}, \mathrm{d} \varepsilon_{1}{ }^{\mathrm{e}}, \mathrm{d} \varepsilon_{1}{ }^{\mathrm{p}}$
$\mathrm{d} \varepsilon_{3}{ }^{\mathrm{t}}, \mathrm{d} \varepsilon_{3}{ }^{\mathrm{e}}, \mathrm{d} \varepsilon_{3}{ }^{\mathrm{p}}$
$\varepsilon_{\mathrm{v}}{ }^{\mathrm{t}}, \varepsilon_{\mathrm{v}}{ }^{\mathrm{e}}, \varepsilon_{\mathrm{v}}{ }^{\mathrm{p}}$
$\phi^{\mathrm{b}}{ }^{\mathrm{b}}$
$\phi$
$\gamma$
$\gamma_{\mathrm{s}}$
$\gamma_{\mathrm{d}}$
$\mathrm{k}$
$\mathrm{k}_{\mathrm{s}}$
$\lambda$
$\sigma$
$\sigma_{\mathrm{a}}$

$\sigma 1, \sigma 2, \sigma 3$

$\sigma_{1}^{\prime}, \sigma_{2}^{\prime}, \sigma_{3}$

$\sigma_{\mathrm{x}}, \sigma_{\mathrm{y}}, \sigma_{\mathrm{z}}$

$\sigma_{\mathrm{v}}$

$\sigma_{1}-\sigma_{3}$

$\sigma_{\mathrm{c}}-\mathrm{u}_{\mathrm{a}}$

$\sigma_{\mathrm{v}}-\mathrm{u}_{\mathrm{a}}$

$\sigma-\mathrm{u}_{\mathrm{a}}$

u

$\mathrm{U}_{50}$

$\psi$

$\psi_{\mathrm{p}}$

$\psi_{\mathrm{m}}$

$\psi_{\mathrm{o}}$

$\psi_{\mathrm{z}}$
Deformação axial.

Deformação axial (principal maior) total, elástica e plástica.

Deformação radial (principal menor) total, elástica e plástica.

Acréscimo de deformação axial total, elática e plástica.

Acréscimo de deformação radial total, elástica e plástica.

Deformação Volumétrica total, elástica e plástica.

Ângulo de atrito do solo em relação à sucção.

Ângulo de atrito efetivo do solo.

Peso específico do solo.

Peso específico das partículas sólidas.

Peso específico seco.

Índice de recompressão isotrópica do solo.

Índice de recompressão do solo em relação a sucção.

Índice de compressão isotrópica do solo.

Tensão normal total.

Tensão axial.

Tensões principais totais maior, intermediária, e menor.

Tensões principais efetivas maior, intermediária, e menor.

Tensões normais nas direções x, y e z.

Tensão vertical total.

Tensão desviadora.

Tensão confinante líquida.

Tensão vertical líquida.

Tensão normal líquida.

Coeficiente de Poisson.

Coeficiente de Poisson para um nível de tensão correspondente a 50 \% da tensão de ruptura.

Potencial total da água no solo.

Potencial pneumático.

Potencial matricial

Potencial osmótico

Potencial gravitacional 


\section{RESUMO}

REIS, R. M. “Comportamento Tensão-Deformação de dois Horizontes de um Solo Residual de Gnaisse”. São Carlos, 2004. Tese (Doutorado) - Escola de Engenharia de São Carlos, Universidade de São Paulo, São Carlos, 2004.

Neste trabalho estuda-se o comportamento tensão-deformação de dois horizontes de um solo residual de gnaisse, pertencentes a um perfil típico da cidade de ViçosaMinas Gerais, na condição saturada e sob diferentes valores de sucção. O estudo apóiase em ensaios de caracterização física e mineralógica, em ensaios destinados às análises porosimétricas e morfológicas (lâminas delgadas), e em ensaios de compressão triaxial realizados em corpos de prova não saturados e saturados, estes sujeitos a diferentes direções de cisalhamento, em ambos solos, e distintas trajetórias de tensão, no solo jovem. Nos ensaios triaxiais saturados mostra-se que a resistência dos dois solos foi independente da direção de cisalhamento e que a deformabilidade revelou-se mais anisotrópica no solo maduro, que no solo jovem, este visualmente mais heterogêneo. Mostra-se, que o intercepto de coesão cresce com a sucção numa relação que pode ser bem representada por uma função hiperbólica e que o ângulo de atrito interno praticamente não apresentou variação com a sucção matricial. Apresenta-se uma alternativa de previsão da envoltória de resistência, baseada nos parâmetros de resistência do solo saturado e nos resultados de ensaio correspondente a uma sucção conhecida. A curva de plastificação do solo jovem pôde ser representada razoavelmente bem pela curva adotada nos modelos derivados da mecânica dos solos dos estados críticos (Cam-Clay modificado). A curva é centrada no eixo hidrostático e sua forma não apresenta mudança marcante durante o encruamento do solo, o qual foi obtido através da união de pontos com o mesmo trabalho plástico.

Palavras-chave: Solos residuais, resistência ao cisalhamento, anisotropia, solos não saturados, curva de plastificação. 


\section{ABSTRACT}

REIS, R. M. (2004). Stress-Strain Behavior of Two Horizons of a Residual Soil from Gneiss. São Carlos, 2004. Tese (Doutorado) - Escola de Engenharia de São Carlos, Universidade de São Paulo, São Carlos, 2004.

This thesis deals with the stress-strain behavior of a mature soil and a young soil from a typical residual soil of gneiss, as found in Viçosa-MG. This behavior is analyzed under saturated and non saturated conditions. The study rests on physical and mineralogical characterization tests, on porosimetric and morphological analyses (thin section) and on triaxial compression tests performed with saturated and non saturated soil. Saturated young and mature specimens were sheared according to different directions and saturated young soil was also sheared following various stress path. It is shown that the shear strength of saturated soil, both mature and young is independent of shearing direction. However, the visually more homogeneous mature soil showed to be more anisotropic, regarding the deformability, than the young residual soil that visually seems to be heterogeneous. The cohesion intercept tends to increase with soil suction according to a non linear relationship that can be adjusted through a hyperbolic function, while the angle of shearing stress was not influenced by soil suction. An alternative to forecast unsaturated shear strength envelope based on results of saturated soil and on tests performed at a known suction is also presented. The yielding curve of young soil was found to be fairly predicted using modified Cam-Clay model. The yield curve is centered along the hydrostatic axis of stress and its shape didn't change during soil strain hardening that was obtained by joining the points to that exhibited the same plastic work.

Key Words: Residual soils, shear strength, anisotropy, unsaturated soils, yielding curve. 


\section{INTRODUÇÃO}

Os solos residuais mostram estruturas peculiares determinadas pelos processos de alteração que os formaram. Em função do grau de alteração, alguns materiais formados não mantêm características da rocha matriz, enquanto outros são muito influenciados pelas estruturas reliquiares herdadas. Os processos de alteração causam perda de minerais, redução de rigidez e o alívio de tensões atuantes na rocha de origem. Alguns vínculos são enfraquecidos ou mesmo destruídos e o índice de vazios e a densidade resultante não estão associados diretamente ao histórico de tensões, como é comum em solos argilosos saturados, de natureza sedimentar.

Em regiões de clima tropical úmido onde as condições climáticas são favoráveis para a ocorrência de solos residuais, como é o caso do Brasil, o conhecimento do comportamento destes solos torna-se importante, uma vez que camadas de solos residuais, na maioria das vezes, apresentam-se com espessuras consideráveis constituindo fator de grande relevância na estabilidade de encostas e outras obras de engenharia.

Ao se trabalhar com solos residuais, dois pontos básicos devem ser destacados: comportamento diferenciado, em relação aos solos sedimentares para os quais a mecânica dos solos clássica foi desenvolvida, proporcionado pelo seu processo de formação (intemperismo) e o fato de que na maioria das vezes eles encontram-se em condições não saturadas. O não reconhecimento destas particularidades tem apresentado um alto custo para as obras geotécnicas, como por exemplo, danos causados por solos expansivos e colapsíveis, conforme relatos na literatura especializada. Dentre os tipos de danos mais comuns causados por estes solos, onde a mineralogia é variada, tem-se, por exemplo, a expansão de solos sob estrutura de pequeno porte e aterros rodoviários, a instabilização ou ruptura de taludes ou obras de contenção em presença de solo expansivo e recalques de estruturas causados pelo colapso de solos de fundação. 
Neste trabalho estuda-se o comportamento tensão-deformação de dois horizontes de um solo residual de gnaisse, compreendendo o solo maduro e o solo saprolítico, pertencentes a um perfil típico da cidade de Viçosa-Minas Gerais, na condição saturada e sob diferentes valores de sucção. O estudo apóia-se em ensaios de caracterização física e mineralógica e em ensaios destinados às análises porosimétricas e morfológicas (lâminas delgadas). A avaliação do comportamento mecânico dos solos maduro e saprolítico é feita através de ensaios de compressão triaxial em amostras saturadas e não saturadas, variando-se as direções de cisalhamento, em ambos solos, e as trajetórias de tensão aplicadas aos corpos de prova, no solo jovem.

Nesse contexto, procurou-se verificar a influência da direção de carregamento (anisotropia) na resistência e na deformabilidade, em amostras saturadas, obter a forma de variação da resistência ao cisalhamento com a sucção e obter as curvas de plastificação, no solo jovem, na condição saturada e em diferentes valores de sucção.

A tese inicia-se com uma revisão bibliográfica (Capítulo 2) onde se procura abordar aspectos importantes referentes ao comportamento de solos residuais, que serão apresentados e discutidos no decorrer do trabalho. Comenta-se sobre a gênese de solos residuais, os fatores que interferem no comportamento tensão versus deformação, tais como a estrutura cimentada, a anisotropia e a condição não saturada, e, por último, as curvas de plastificação de modelos baseados na teoria dos estados críticos. Neste último item aborda-se a curva de plastificação do modelo dos estados críticos (Cam Clay modificado), elaborado para solos saturados, e a curva de plastificação para solos não saturados proposta por Alonso et al. (1990).

No capítulo 3, são apresentados os materiais e os métodos utilizados na realização dos diversos ensaios, cujos resultados são mostrados neste trabalho. Inicia-se abordando características gerais da área de estudo, tais como: localização geográfica, dados climatológicos, geologia, geomorfologia e pedologia. Em seguida aborda-se o perfil de solo escolhido para estudo, onde são apresentados os horizontes B (Latossolo Vermelho-Amarelo) e C (Solo Saprolítico). Por último são descritos os procedimentos adotados na realização dos ensaios, que compreenderam os ensaios de caracterização geotécnica, de caracterização mineralógica, de análises porosimétricas e micromorfológicas, e de ensaios de compressão triaxial.

No capítulo 4 apresentam-se os resultados obtidos dos ensaios comentados anteriormente e nos capítulos subseqüentes estão apresentadas as análises e conclusões obtidas através dos ensaios realizados, para os dois horizontes, envolvendo: os 
resultados dos ensaios de mineralogia, porosimetria, lâminas delgadas, as curvas tensão versus deformação, a influência da direção de carregamento (anisotropia) na resistência e na deformabilidade, a variação da resistência com a sucção, e as curvas de plastificação, no solo jovem, na condição saturada e sob diferentes valores de sucção. 


\section{REVISÃO BIBIOGRÁFICA}

Este capítulo é dividido da seguinte maneira. Em primeiro lugar, aborda-se a gênese dos solos residuais, comentando-se sobre os processos intempéricos, os produtos do intemperismo, o intemperismo tropical e também sobre o perfil de alteração de um solo residual. Em segundo lugar, comenta-se sobre os fatores que interferem no comportamento tensão-deformação e resistência de solos residuais, tais como a estrutura cimentada, anisotropia, condição não saturada e, também são abordados alguns trabalhos que tiveram como objetivo o estudo da resistência e deformabilidade ao longo de um perfil de solo residual. Por último são abordadas as curvas de plastificação do modelo dos estados críticos (Cam-Clay modificado), elaborado para solos saturados, e a curva de plastificação para solos não saturados proposta por Alonso et al. (1990).

\subsection{Gênese de solos residuais}

\subsubsection{Generalidades}

A partir do momento da exposição das rochas à superfície ou próximo desta, diversos agentes do intemperismo, bastante diferenciados entre si, tanto no tipo como na agressividade, motivam progressivas transformações nos minerais originais até que, em último estágio, seja produzido sua total desintegração.

A intemperização das rochas modifica os minerais originais, conferindo-lhes novas propriedades físicas e químicas e transformando, ao final do processo, a antiga rocha em um material totalmente incoerente, designado por solo, sob o ponto de vista geológico-geotécnico.

A intemperização das rochas ocorre predominantemente no sentido da superfície ao interior do maciço rochoso, descrevendo uma série de horizontes com diversificados níveis de intemperização. Aos materiais originados pela intemperização in situ e sem ocorrência de transporte atribuímos o nome de residuais. 
A Figura 2.1 mostra esquematicamente as etapas até a formação dos solos, a partir da intemperização da rocha de origem.

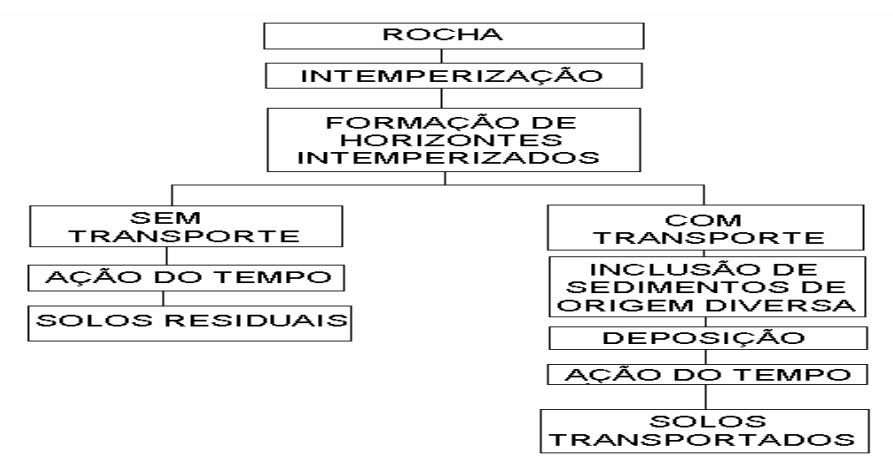

Figura 2.1 - Esquema de formação dos solos.

Segundo Blight (1997) solo residual pode ser definido razoavelmente cono sendo todo o solo formado a partir da decomposição das rochas (ígneas, metamórficas ou sedimentares) pelo intemperismo químico, físico e biológico, que permanece no local onde foi formado sem sofrer qualquer tipo de transporte.

O intemperismo é um processo que modifica a estrutura e as propriedades do solo independente de sua história de tensões. A gênese dos solos residuais apresenta, desta forma, um problema particular em relacionar a estrutura do solo e sua história de tensões, pois ambos mudam continuamente.

A estrutura resulta diretamente dos processos físicos e químicos no campo que alteram uma dada rocha matriz para formação do solo residual. As mudanças geoquímicas envolvidas na transformação da rocha em solo residual têm sido estudadas extensivamente. De acordo com Vaughan \& Kwan (1984) elas podem envolver:

a) enfraquecimento da rocha por alteração e remoção de material, acompanhado por perdas de massa, resistência e rigidez e por um aumento de porosidade;

b) aumento de volume sob tensão efetiva constante, caso o intemperismo produza minerais argílicos expansivos, e caso a perda de massa durante o intemperismo não venha a equilibrar a expansão destes minerais argílicos;

c) efeitos não químicos devido a mudanças na tensão efetiva, provenientes de ressecamento e inchamento, que podem ser cíclicos.

Quanto a história de tensão, de acordo com Vaughan \& Kwan (1984), deve ocorrer um descarregamento vertical durante o intemperismo, decorrente da perda de peso e devido a erosão superficial. Como o solo é continuamente modificado pelo 
intemperismo durante este descarregamento, o efeito de tensões prévias em sua estrutura deve ser minimizado ou removido. Deve-se resaltar que a estrutura atual de um solo residual está em equilíbrio e é associada ao seu atual estado de tensão, e que o efeito de tensões anteriores, às quais ele foi submetido durante sua evolução, será pequeno.

As partículas sólidas presentes devido ao processo de intemperismo serão grãos minerais individuais ou aglomerados de grãos originados da rocha matriz, com vários graus de alteração e enfraquecimento, como também grãos ou aglomerados criados pelo processo de intemperismo.

Os solos residuais podem apresentar uma ampla faixa de porosidade, mesmo quando derivados de uma mesma rocha matriz. Na Tabela 2.1, estão reproduzidos valores típicos de densidade de grãos e índice de vazios de solos residuais encontrados no Brasil (Sandroni, 1985).

Tabela 2.1 - Variações típicas no índice de vazios in-situ em Solos Residuais Brasileiros (Sandroni, 1985).

\begin{tabular}{|c|c|c|}
\hline Rocha Matriz & Densidade dos Grãos & Índice de Vazios \\
\hline Gnaisse & $2,6-2,8$ & $0,3-1,1$ \\
\hline Quartzito & $2,65-2,75$ & $0,5-0,9$ \\
\hline Xisto & $2,7-2,9$ & $0,6-1,2$ \\
\hline Filito e Ardósia & $2,75-2,9$ & $0,9-1,3$ \\
\hline Basalto & $2,8-3,2$ & $1,2-2,1$ \\
\hline
\end{tabular}

Vários pesquisadores (Leroueil \& Vaughan, 1990; Costa Filho et al., 1989; Maccarini, 1989; Vaughan, 1985; Vaughan et al., 1988) consideram a presença de uma estrutura fracamente cimentada, independente do histórico de tensões, como feição dominante em solos residuais, a qual contribui para a resistência e rigidez destes solos.

Estas cimentações podem ser quebradas pela deformação do solo durante o carregamento. Uma vez quebradas estas ligações são irrecuperáveis, exceto pela escala de tempo dos processos geológicos que as criaram. A resistência dessas ligações é análoga, mas diferente da componente coesiva da resistência presente em argilas, em virtude das forças de atração entre suas partículas. Esta última componente pode ser recuperada pelo menos parcialmente, se a densidade e o arranjo das partículas forem recuperados.

Vaughan et al. (1988) sugerem que as principais características de engenharia dos solos residuais que surgem de sua origem geológica, são as seguintes: 
a) Uma componente da resistência e rigidez devida às ligações entre partículas, que se desenvolveram progressivamente com a evolução do solo, e que estão em equilíbrio com atual estado de tensões in-situ;

b) Um pequeno efeito da história de tensão que acompanhou sua evolução na atual estrutura do solo;

c) Variada mineralogia e resistência dos grãos;

d) Ampla faixa de porosidade.

\subsubsection{Processos Intempéricos}

Basicamente, o processo de intemperização das rochas pode ser resumido em três fases principais:

a) desintegração das rochas por fenômenos físicos ou mecânicos;

b) decomposição química das rochas; e

c) processo evolutivo, que acaba por transformar a rocha coerente em solo.

A terceira e última fase, chamada de processo evolutivo consiste na ação combinada dos efeitos da desintegração física e, mais pronunciadamente, as reações nos minerais, produzidas pela decomposição química.

O intemperismo físico atua no sentido de alterar o tamanho das partículas, quebrando o material de origem, sem variação significante na composição. Processa-se, principalmente, pelos seguintes efeitos: expansão diferencial por alívio de tensões (proporcionada pela erosão das camadas superiores), crescimento de cristais estranho à rocha, fenômenos de contração e expansão por variações de temperatura e efeitos mecânicos produzidos pelo crescimento das raízes (cunha).

São processos físicos, por exemplo, alívio de tensões pela erosão, deformação por variação de temperatura e congelamento, e pressões de cristalização de sais depositados em fraturas, os responsáveis pelo intemperismo mecânico, que tem como conseqüências modificações nas dimensões dos indivíduos mineralógicos das rochas e na área e no volume por eles ocupado. Os processos físicos atuam, de tal maneira que não provocam qualquer alteração sensível na composição mineralógica das rochas. Os processos físicos fragmentam a rocha, expondo novas superfícies para o ataque químico, e em conseqüência, a permeabilidade do material é aumentada para a percolação de fluidos quimicamente reativos. 
O intemperismo químico é um processo caracterizado pela ocorrência de reações químicas entre os minerais constituintes da rocha e soluções aquosas de diferentes composições, que modificam os minerais originais das rochas transformando suas características químicas e físicas.

Segundo Mitchell (1976) processos químicos, principalmente hidrólise e oxidação, alteram os minerais da rocha original para formar argilo-minerais mais estáveis.

Quanto aos processos químicos do intemperismo:

a) provocam modificações complexas das propriedades físicas e químicas das rochas;

a) originam novos minerais, porque destroem as estruturas cristaloquímicas dos minerais endógenos, libertando os seus íons que se recombinam, ou emigram, uma vez libertados; e

b) aumentam o volume global das rochas que se intemperizam, porque os novos minerais são menos densos.

O intemperismo biológico inclui ambos, ação física (por exemplo, fendilhamento pela penetração da raiz) e ação química (por exemplo, oxidação bacteriológica, redução de ferro e compostos sulfúricos, conforme sugerido por Pings (1968)). Os processos biológicos resultantes da ação dos seres vivos, animais ou plantas, tanto podem ser de natureza física ou química pois podem não só provocar a desagregação, mas também modificações nas composições mineralógica e química das rochas.

Solos residuais formam-se a partir de rochas ígneas, metamórficas e sedimentares. Processos químicos tendem a predominar em intemperismo de rochas ígneas, ao passo que processos físicos dominam o intemperismo de rochas metamórficas e sedimentares. Porém, intemperismo químico e físico são tão intimamente interrelacionados que um processo não procede sem alguma contribuição do outro.

\subsubsection{Produtos do Intemperismo}

Os produtos do intemperismo podem ser solúveis, colóides ou residuais. 
Os produtos solúveis e colóides são removidos do complexo de intemperismo, pelas águas que atravessam (sulfatos, cloretos, carbonatos, etc.), e os produtos residuais acumulam-se nos locais, em que ocorre o intemperismo.

Entre os produtos residuais do intemperismo, incluem-se minerais insolúveis ou pouco solúveis, como quartzo, opala, calcedônia, minerais das argilas (caulinitas, montmorilonitas, ilita, etc), micas, óxidos e hidróxidos de alumínio e de ferro (gibsita, goethita, etc), minerais, praticamente, inalteráveis, como o zircão, a turmalina, etc, e minérios, como o ouro, a platina, a cassiterita, etc.

\subsubsection{Intemperismo tropical}

A análise da geoquímica do intemperismo (meteorização), em climas quentes e pluviosos, segundo Guimarães (1998), conduz às seguintes conclusões:

a) O clima quente e pluvioso, faz com que os silicatos das rochas, como uma conseqüência da grande quantidade de água das chuvas abundantes, que as atravessam, e da temperatura elevada, sofram uma hidrólise acentuada, e o resultado será a libertação dos íons das estruturas dos silicatos $\left(\mathrm{Si}^{4+}, \mathrm{Al}^{3+}, \mathrm{Fe}^{2+}, \mathrm{Ca}^{2+}, \mathrm{K}^{+}, \mathrm{Na}^{+}\right.$, etc).

b) Os íons libertados têm destinos diferentes.

c) Os íons $\mathrm{Na}^{+}, \mathrm{K}^{+}, \mathrm{Ca}^{2+}$ e $\mathrm{Mg}^{2+}$ são eliminados do complexo de meteorização, pelas águas das chuvas que o atravessam.

d) $\mathrm{O}$ íon $\mathrm{Si}^{4+}$ pode ser eliminado do complexo de meteorização ou ser, parcialmente, retido.

e) Os íons $\mathrm{Al}^{3+}$ e $\mathrm{Fe}^{2+}$ permanecem, em grande parte, dentro do complexo de meteorização, originando neoformações, como a gibsita, a hematita e a goethita. $\mathrm{O} \mathrm{Si}^{+4}$, que não for eliminado, associa-se ao $\mathrm{Al}^{3+}$ para originar a caulinita.

f) A gênese dos minerais indicados depende da intensidade da lixiviação, ligada à maior, ou à menor facilidade, com que ocorre a drenagem da água do complexo de meteorização, ou dos perfis dos solos, que lhe estão associados.

Três casos podem ser considerados:

a) Nos meios bem drenados (lixiviação acentuada), os íons $\mathrm{Si}^{4+}$ dissolvidos são eliminados do complexo de intemperismo, e as soluções com os produtos, derivados da 
hidrólise dos silicatos, formam a gibsita e a goethita, sobretudo quando a rocha é pobre em íons $\mathrm{Si}^{4+}$.

b) Nos meios bem drenados, mas com o lençol freático permanente (lixiviação moderada), ou se a rocha é rica em íons $\mathrm{Si}^{4+}$, nem todos esses íons são eliminados. Nestas condições, partes dos óxidos de alumínio formados são ressilificados, pelos íons não-eliminados, para darem origem à caulinita.

c) Nos meios sem drenagem, ou mal drenados (lixiviação nula, ou fraca), todos os cátions libertados por hidrólise, entre eles o $\mathrm{Si}^{4+}$, tornam-se abundantes no complexo de meteorização, e forma-se a montmorilonita, silicato que é definitivo nos solos calcimorfos (argilas negras tropicais)

O que foi descrito para os meios bem drenados das regiões tropicais quentes e pluviosas corresponde a um processo pedogenético, que se designa por ferratilização e, muitas vezes, designado por “latolização”, ou meteorização “laterítica”.

O que foi exposto, principalmente no que diz respeito às condições de drenagem como uma das responsáveis pelo tipo de mineral presente no solo, é muito importante pois estes minerais influenciam de maneira decisiva no comportamento do solo, cada um tendo uma influência diferente, e assim determinando aos solos comportamentos diferentes (colapso, expansão, etc).

Novais Ferreira (1985) comenta a dificuldade de identificação e classificação dos solos tropicais, saprolíticos e lateríticos e apresenta um perfil de alteração básico para as regiões tropicais, com a indicação dos principais compostos normalmente presentes em cada horizonte:

a) Rocha mãe, intacta, sã;

b) Rocha parcialmente alterada;

c) Rocha alterada, zona de transição;

d) Saprolito (estruturas reliquiares da rocha de origem presentes, porém com características de solo quando removidos, distribuições granulométricas variando entre silte e areia, muitas vezes micáceo);

e) Solo (provavelmente rico em haloisita, caulinita, gibsita e outros minerais oriundos da rocha mãe em adiantado estado de intemperização ou totalmente alterados);

f) Zona Variegada (provavelmente rica em gibsita, goethita, caulinita e hematita) 
g) Zonas Concrecionadas (com predominância de ferro e alumínio);

h) Horizonte A pedológico, solo.

A Figura 2.2 ilustra um possível perfil de solos tropicais idealizado por Cruz (1987). Esse perfil é resultante de uma intemperização, principalmente química, associada à lixiviação e laterização. Na Figura 2.3, Cruz (1987) idealiza modelos teóricos de estruturas possíveis para os horizontes identificados no perfil de alteração da Figura 2.2.

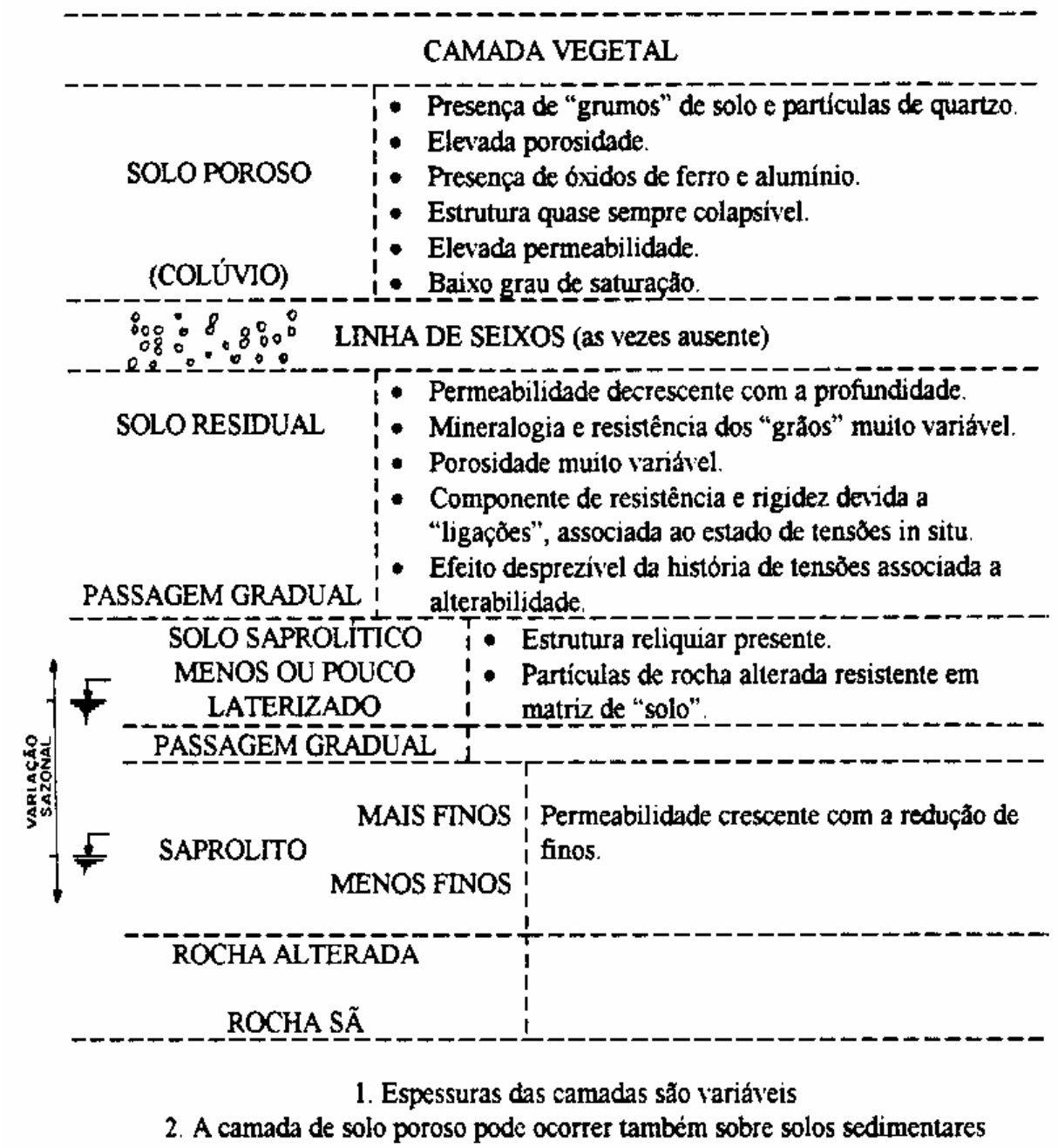

Figura 2.2 - Perfil Possível de Solos Tropicais (Cruz, 1987). 

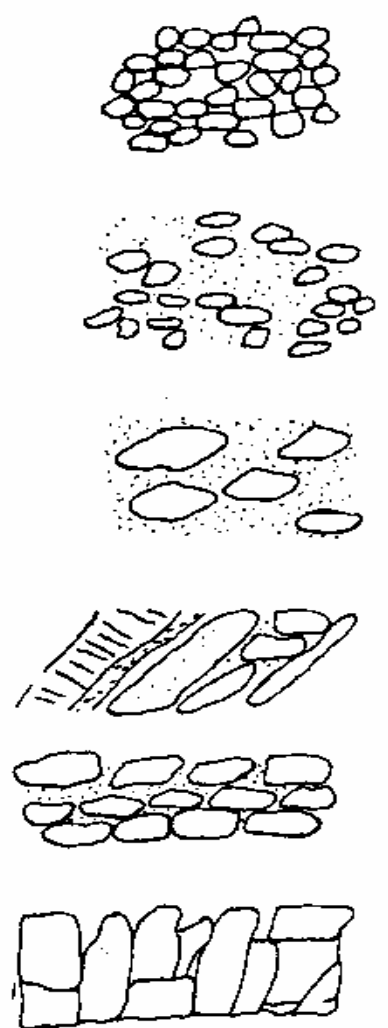

SOLO POROSO - "grumos de particulas de solo" cimentados por óxidos de ferro e alumínio - particulas de quartzo resistentes - macro-poros - permeabilidade elevada - solo colapsivel

SOLO RESIDUAL - "grumos de solo" - particulas de laterita e/ou quartzo - macro e micro-poros - permeabilidade variável solo colapsivel, ou estável solo laterítico

SOLO SAPROLFTICO - lateraçăo menor, ou pouco significativa - presença de partículas, grãos de rocha alterada - matriz de solo pouco resistente

SOLO SAPROLITITICO ORIGINÁRIO DE ROCHA BANDEADA - estrutura reliquiar manifesta

SAPROLITO COM FINOS - "blocos de rocha alterada" com preenchimento de vazios com solo - permeabilidade "baixa"

SAPROLITOS SEM FINOS - vazios pouco preenchidos por solo - camada "permeável" - fluxo pelas fraturas não preenchidas por solo

Figura 2.3 - Modelos Estruturais (Cruz, 1987).

As condições requeridas para a formação dos horizontes de solos lateríticos ou concrecionados são basicamente as seguintes:

a) Rocha que dá origem ao perfil de alteração deve ser rica em minerais de ferro ou alumínio;

b) Perfil deve ser permeável, permitindo boa circulação de água;

c) Clima tropical com estações chuvosas e secas e elevada umidade;

d) Elevadas temperaturas;

e) Topografia favorável;

f) Flutuação do nível freático;

g) Vegetação da floresta tropical ou savana.

No item seguinte será tratado com mais detalhe os perfis de alteração, tendo aqui o objetivo meramente ilustrativo de apresentar, teoricamente, a existência e disposição dos horizontes que o compõem. 


\subsubsection{Perfis de alterações de solos residuais}

\subsubsection{Introdução}

Deere \& Patton (1971) definem como perfil de intemperização (alteração) a seqüência de camadas, com diferentes propriedades físicas, desenvolvidas no mesmo local da rocha não intemperizada.

De Mello (1972) estabelece a definição de um perfil de alteração como um elemento que deve traduzir, como implicação básica, o fato de que existe um contínuo absoluto de transição gradual dos parâmetros geotécnicos médios em função, principalmente, do incremento da profundidade. Salienta porém, que os horizontes distintos que compõem o perfil de alteração, se misturam e suas dimensões variam na ordem métrica de maneira errática, tanto na vertical como horizontalmente. Desta forma, em um âmbito mais específico, poder-se-ia dizer que esses horizontes distintos não existem.

De Mello (1972) explica que esses horizontes distintos existem em aparência, porém os graus de precisão segundo os quais os mesmos poderão ser estabelecidos ou utilizados para indicar comportamentos distintos dos solos, são demasiado pequenos para que possam ser empregados como dado de entrada para o projeto final ou para tomada de decisões sobre processos construtivos.

O perfil de intemperização pode ser formado, conforme comentado anteriormente, por intemperização mecânica, desintegração da estrutura original da massa rochosa, ou por intemperização química. No entanto a desintegração mecânica poderia se apresentar acelerando a decomposição química.

O perfil de intemperização pode variar consideravelmente de lugar a lugar devido as variações locais do tipo de rocha, estrutura rochosa, topografia, nível de erosão e condições da água subterrânea, e também pelas variações do clima, particularmente as precipitações.

O intemperismo e o seu grau de intensidade, assim, como os minerais, que constituem o complexo de intemperismo, dependem dos seguintes fatores:

a) da natureza da rocha, dependente sobretudo da sua composição mineralógica, a qual terá influência sobre a resistência da rocha ao intemperismo; 
b) do tipo de clima condicionado, pela temperatura, pela pluviosidade e pela umidade;

c) do relevo da região que favorece, ou dificulta, a circulação da água, por meio do complexo de intemperismo;

d) da duração dos processos de intemperismo;

e) da ação dos seres vivos, sobretudo vegetais e microorganismos; e

f) da dinâmica do meio, em que ocorre o intemperismo, que corresponde à relação entre a velocidade do intemperismo e a velocidade de remoção dos produtos, originados pelos processos de intemperismo (intervenção da intensidade da drenagem da água, que atravessa o meio em intemperismo).

\section{A GEOLOGICAL SOCIETY ENGINEERING GROUP WORKING PARTY}

REPORTS (1990) sintetiza, de forma generalizada, as condições ótimas para formação de perfis de alteração profundos:

a) Clima equatorial úmido ou de monções com precipitações de 2000 a 5000 mm/ano e histórico de sazonalidade moderada durante o Quaternário (últimos 10000 anos) e latitude tropical ao longo do Mesozóico e Cenozóico;

b) Superfícies de margens passivas que recobrem rochas cristalinas máficas a intermediárias ou sedimentos acroseanos, sob a influência de soerguimentos dômicos, falhas e fraturamento, atividade ígnea extrusiva e possivelmente hidrotermalismo;

c) Locais como divisores de água ou platôs, com declividades inferiores a $15^{\circ}$ que não apresentam ravinamento ou remoção do perfil durante o Quaternário.

Por outro lado, citam-se como condições adversas à formação de perfis de alteração profundos as seguintes situações:

a) Longos períodos de climas áridos ou semi-áridos;

b) Terrenos de cinturões móveis e terrenos sujeitos a dobramento, falhamento e soerguimento, constituídos por rochas cristalinas félsicas ou rochas sedimentares quartzosas;

c) Encostas de forte declividade ou locais de cristais abruptas;

d) Interflúvios com pouca cobertura vegetal. 
A Tabela 2.2 apresenta algumas espessuras típicas de perfis de alteração reportadas por Sowers (1963).

Tabela 2.2 - Espessuras de Pefis de Alteração (Sowers, 1963).

\begin{tabular}{|c|c|}
\hline REGIÃO & ESPESSURA (metros) \\
\hline $\begin{array}{c}\text { Piedmont, Southeastern } \\
\text { USA }\end{array}$ & 6 a 15 \\
\hline Angola, África & 8 \\
\hline Sul da Índia & 8 a 15 \\
\hline Sul da África & 9 a 18 \\
\hline Leste da África & 10 a 20 \\
\hline Brasil & 10 a 25 \\
\hline
\end{tabular}

\subsubsection{Classificações para o perfil de Alteração}

Vários estudos foram realizados tendo como objetivo o entendimento do perfil de intemperização de um solo residual. A seguir são apresentados alguns trabalhos dentre os vários trabalhos existentes sobre perfil de intemperização.

Vargas (1953) apresentou a primeira classificação genética dos solos tropicais brasileiros, distiguindo três horizontes: solo residual maduro, argiloso e poroso, solo residual jovem, silto-arenoso, com a presença de estruturas reliquiares e rocha alterada, cuja remoção obrigava ao uso de explosivos. Nesse trabalho, Vargas apresenta dois perfis de intemperização na região sudeste do Brasil, um em São Paulo e outro no Rio de Janeiro, mostrando a decomposição de rochas gnáissicas.

Vaz (1969) apresenta uma classificação baseada em perfil de intemperismo, com cinco horizontes, dois de solo e três de rocha: solo superficial, homogêneo e isotrópico; solo de alteração, heterogêneo e anisotrópico; rocha alterada mole, escavável à picareta e rocha alterada dura e sã, estas últimas escaváveis somente com explosivos.

Deere \& Patton (1971) realizaram extenso estudo sobre perfis de intemperismo em regiões de clima tropical, inclusive no Brasil, propondo três horizontes com subdivisões, resultando em três horizontes de solo e três de rocha: horizonte I, de solo residual, com subdivisões de solo orgânico (IA), solo laterítico (IB) e saprolito, com estruturas reliqueares da rocha matriz (IC); horizonte II, de rocha alterada, com subdivisões de transição com a presença de matacões (IIA) e rocha alterada (IIB) e horizonte III, de rocha sã. 
Vargas (1974) adere à classificação baseada em perfis de intemperismo e apresenta cinco horizontes, três de solo e dois de rocha: horizonte I, de solo residual maduro; horizonte II, de solo com vestígios eventuais das estruturas reliqueares da rocha; horizonte III, de solo com estruturas e matacões (saprolíto); horizonte IV, de rocha alterada com zonas decompostas e horizonte $\mathrm{V}$, de rocha sã.

Vargas (1985) apresenta uma classificação baseada em propriedades e comportamentos, identificando dois tipos de solos tropicais: residual, derivado do intemperismo intenso e profundo da rocha subjacente e solos superficiais, derivados da evolução pedogenética de solos residuais e transportados. Para os solos residuais admite um horizonte inferior, com estruturas reliqueares da rocha matriz (saprolito) subdividido em dois níveis: um superior, chamado de saprolito fino, com poucos fragmentos da rocha matriz e outro inferior, com blocos e camadas de rocha.

Wolle et al. (1985) reconhecem seis horizontes de intemperismo, três de solo, um de transição e dois de rocha: solo superficial que, quanto a origem, pode ser residual, coluvionar ou sedimentar; solo residual maduro, solo residual jovem ou solo saprolítico, com estruturas da rocha matriz; saprolito, constituindo uma zona de transição entre solo e rocha, com matacões; rocha alterada ou decomposta e rocha fresca.

Pastore (1992) segue a tendência de perfis de intemperismo e estabelece seis horizontes, dois de solo, um com predominância de processos pedológicos (solo laterítico) e outro com estruturas reliquiares da rocha (solo saprolítico); um de transição solo/rocha (saprolito) e três de rocha (muito alterada, alterada e sã).

Vaz (1996) apresenta uma classificação com cinco horizontes: dois de solo e três de rocha. Os horizontes de solo são divididos em solo eluvial, chamado por alguns autores de solo maduro, homogêneo e isotrópico, sujeito aos processos pedogenéticos e solo de alteração ou saprolito, caracterizando um material que ainda sofre processo de alteração intempérica e que guarda eventuais estruturas da rocha e é heterogêneo e anisotrópico. Os horizontes de rocha são divididos em rocha mole, rocha alterada mole, rocha alterada dura e rocha sã.

Vários outros autores também contribuiram para o estudo dos solos tropicais, destacando-se Kiersh \& Treasher (1955), Moye (1955), Ruxton \& Berry (1957), Sowers (1953, 1963), Knill \& Jones (1965), Vargas, et al. (1965), Sowers 1967, Nogami (1967), Barata (1969), Little (1967/1970), Saunders et al. (1970), De Mello (1972), Mori et al. (1978), Sardinha et al. (1981). 
A partir de 1981 parece existir uma tendência internacional (IAEG, 1981; ISRM,1981) de utilização de classificações subdivididas em seis classes de intemperização, normalmente designadas da seguinte forma:
I Rocha Sã
II Rocha pouco alterada
III Rocha moderamente alterada
IV Rocha Altamente alterada
V Rocha completamente alterada
VI Solo Residual

Segundo estas classificações (IAEG, 1981; ISRM,1981), as quais são muito parecidas:

- Na Classe VI (solo residual), todo o material rochoso está convertido em solo. Não existem mais vestígios de estruturação original. Ocorrem significativas alterações em termos de volume. O material representante desta porção do perfil não sofreu significante transporte.

- Na Classe V (Rocha Completamente Alterada) todo o material rochoso está decomposto e convertido em solo. A estrutura herdada da rocha original está praticamente intacta.

- Na Classe IV ( Rocha altamente alterada) mais de 35\% a 50\% do material rochoso está decomposto e convertido em solo. Rocha sã ou alterada está presente sob a forma de blocos isolados.

- Na Classe III ( Rocha Moderamente Alterada) menos que 35\% a 50\% do material rochoso está decomposto e convertido em solo. Rocha sã ou alterada está presente sob a forma de blocos isolados.

- Na Classe II ( Rocha Pouco Alterada ) existem apenas marcas de intemperização ao longo das descontinuidades existentes no maciço.

- Na Classe I (Rocha Sã ) não são visíveis sinais de intemperização no material rochoso, pode ocorrer um suave ataque nas maiores descontinuidades existentes. 


\subsubsection{Perfis típicos de alteração}

A Figura 2.4 apresenta um diagrama esquemático de um perfil de alteração (Little, 1970).

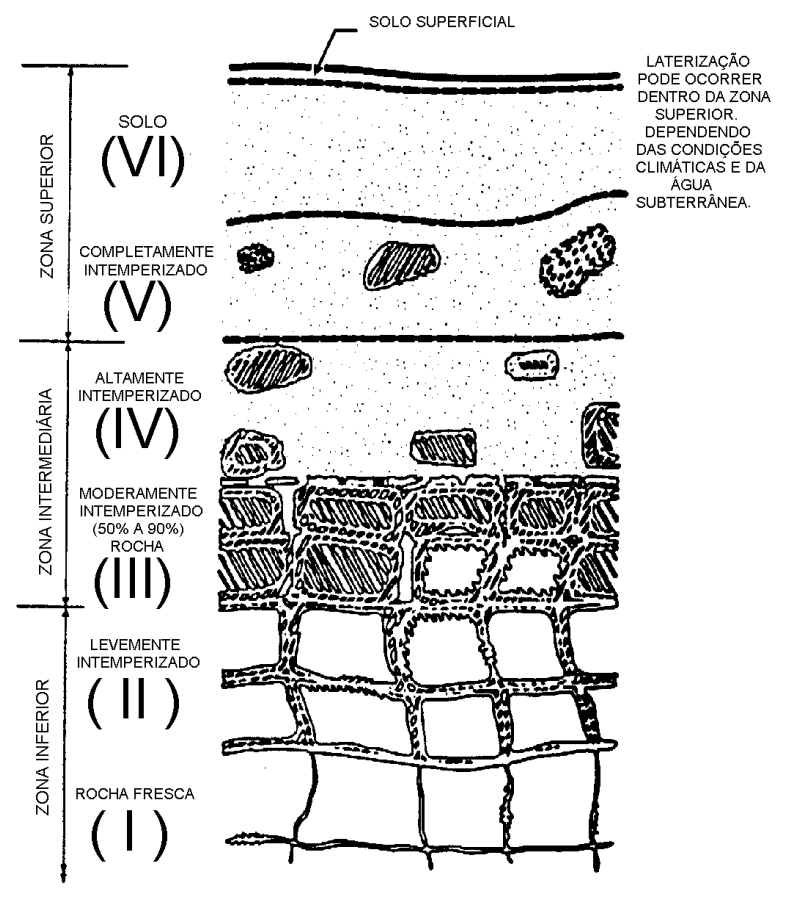

Figura 2.4 - Diagrama esquemático de um perfil típico de solo residual (Little, 1970).

Observa-se desta figura que a rocha vai sendo decomposta gradualmente pelo intemperismo no sentido da superfície ao interior do maciço rochoso, descrevendo uma série de horizontes com diversificados níveis de intemperização. Ainda na Figura 2.4, as zonas (I, II, III) tendem a se comportar como rocha, enquanto as zonas (IV, V, VI) como solo. As zonas IV e V, considerando as diversas classificações nacionais, geralmente pode-se chamar de solo de alteração ou saprolito ou ainda solo residual jovem, pois estes solos guardam características estruturais da rocha matriz. O solo da zona VI pode-se chamar de solo residual maduro, pois é o solo que não guarda nenhuma característica da rocha matriz. Baseado no exposto anteriormente, espera-se que o solo residual maduro seja homogêneo e isotrópico e o solo residual jovem seja heterogêneo e anisotrópico.

Uma definição que merece destaque é a de Laterização, a qual, segundo Barata (1981), pode ser definida como um fenômeno de intemperismo característico das 
regiões de clima quente e úmido (correspondente ao de regiões intertropicais atuais), em que o terreno sofreu (ou sofre) uma acumulação relativa de sesquióxidos de ferro e alumínio, isto é, enriquecimento dos teores de ferro e alumínio, à custa da lixiviação dos componentes mais solúveis, inclusive da sílica. A laterização (ou ferratilização) pode se processar tanto em terrenos sedentários (residuais ou coluviais), quanto em terrenos transportados (sedimentares, principalmente). No caso de solos (sedentários ou transportados) o processo pode atingir graus os mais diversos, de tal modo que o produto resultante poderá variar desde o solo laterítico até a rocha laterítica ou laterita, propriamente dita. Desai (1985) define o grau de laterização em termos da razão sílica e alumínio; Solos não laterizados possuem $\mathrm{S}_{\mathrm{i}} \mathrm{O}_{2} / \mathrm{Al}_{2} \mathrm{O}_{3}$ maior que 2, solos laterizados possuem $\mathrm{S}_{\mathrm{i}} \mathrm{O}_{2} / \mathrm{Al}_{2} \mathrm{O}_{3}$ entre 1,3 e 2 e laterita ou rocha laterítica possuem $\mathrm{S}_{\mathrm{i}} \mathrm{O}_{2} / \mathrm{Al}_{2} \mathrm{O}_{3}$ menor que 1,3 .

A Figura 2.5 mostra algumas mudanças que podem ocorrer no perfil de intemperismo em relação ao índice de vazios, compressibilidade, resistência e concentração de sexquióxidos.

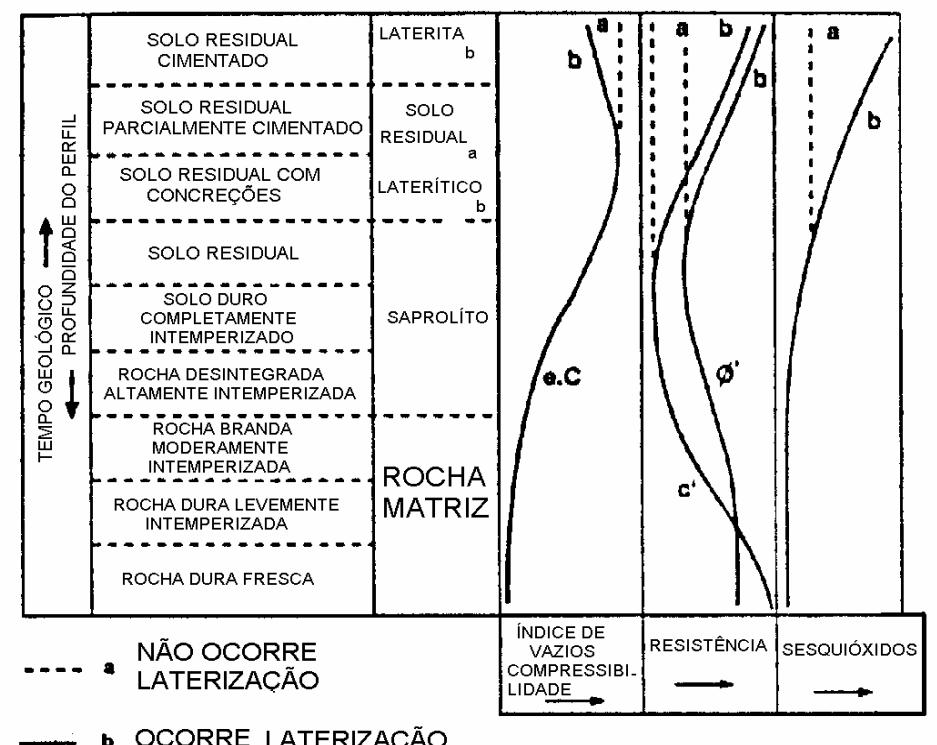

Figura 2.5 - Mudanças ocorrentes no perfil de intemperismo (Blight, 1997).

Quanto ao índice de vazios e a compressibilidade observa-se que quando o material começa a comportar como solo há um aumento em seus valores e que quando ocorre a laterização, por causa da cimentação gerada, há uma diminuição. Quanto a resistência, quando o material comporta como solo há uma diminuição em seu valor e 
quando ocorre a laterização, pelo mesmo motivo anterior, há um aumento em seu valor. Quanto a formação de sesquióxidos, observa-se que eles são formados durante a laterização do solo. A laterização pode ocorrer dentro da zona superior dependendo do clima e das condições de água subterrânea.

\subsubsection{Caracterização dos horizontes do perfil de Alteração}

A seguir são apresentados critérios, qualitativos e quantitativos, que tentam descrever os horizontes componentes do perfil de intemperização, com base nas características usualmente encontradas na definição dos diversos horizontes do perfil típico de intemperização, com base, principalmente, nas classificações apresentadas anterriormente e em outros trabalhos, como por exemplo GEOLOGICAL SOCIETY ENGINEERING GROUP WORKING PARTY REPORTS (1990), IAEG (1991) e ISRM (1991). As descrições dos horizontes que seguem adaptam-se à maioria dos casos e devem ser encaradas como conceituais. As denominações dos horizontes do perfil de alteração estão primeiramente indicadas pelos termos mais correntes e utilizados na bibliografia nacional, entre parênteses estão indicados os termos utilizados internacionalmente (IAEG e ISRM).

\section{- Solo residual maduro - VI (Solo Residual)}

Esta denominação coincide com a utilizada por Vargas (1953), Barata (1969) e Mori et al. (1978). De Mello (1972) utiliza a terminologia Solo Maduro, excluindo a redundância do termo residual. Pode-se de uma maneira geral, utilizar o termo solo, isoladamente, como aparece nas classificações de Moye (1955), Knill \& Jones (1965) e Nogami (1967). Este horizonte corresponde ao último estágio de alteração in situ da rocha-máter que, devido ao estado avançado de intemperização, não mais apresenta vestígios da estrutura da rocha de origem. Todo o material está reduzido a solo. Esta zona corresponde ao horizonte B pedológico.

- Solo de alteração, saprolito ou solo residual jovem - V (Rocha Completamente Alterada)

Nas classificações de Vargas (1953, 1969) e Barata (1969) é chamado de solo residual jovem e na classificação de Vaz (1996) é chamado de solo de alteração ou saprolito. Este horizonte corresponde ao horizonte C pedológico e é facilmente reconhecido por evidenciar a estrutura reliquear da rocha de origem, embora componha 
um estado bastante adiantado de alteração de rocha. Apresenta uma percentagem de blocos de rocha extremamente alterados, que desagregam facilmente com a pressão dos dedos. O caráter de elevada alteração dos minerais que compõem este horizonte, proporciona uma composição essencialmente terrosa. Este material é facilmente amostrado por sondagens a trado, e pode, no geral, ser perfeitamente caracterizado pelos ensaios rotineiros de Mecânica dos solos. Embora, por vezes, ainda exista uma estruturação significativa em determinadas regiões do perfil, que apesar de não caracterizarem mais blocos de rocha alterada, ainda exibem sensível resistência e comportamento diferenciado dos grumos formados pelos solos superficiais. Este horizonte tem seus mecanismos de comportamento mais voltados para o lado da Mecânica dos Solos , em dependência do grau de alteração que confere uma maior ou menor resistência ao conjunto de grãos estruturados pelo arranjo da rocha original. Em seu estado compactado, apresenta-se como excelente material de construção para barragens de terra homogêneas, apresentando resultados bastante satisfatórios inclusive quando utilizados na construção de núcleos relativamente delgados impermeáveis para barragens de enrocamento.

\section{- Saprolito Brando ou Saprolito Fino - IV (Rocha Altamente Alterada)}

Esta denominação coincide com a utilizada por Sardinha et al. (1981). Vargas (1969) utiliza a denominação rocha alterada, Barata (1969) a denominação solo residual jovem e De Mello (1972) a denominação saprolito.

Estágio relativamente adiantado de alteração de rocha. Apresenta blocos com dimensões centi a decimétricas, normalmente originadas a partir do sistema de fraturamento original do maciço. Tais blocos são de difícil desagregação pela pressão dos dedos, porém quebram suas bordas com facilidade quando submetidos a esforços de flexão. Este material, devido a presença, por vezes numerosa, de blocos alterados, ou pela forte estruturação herdada da rocha de origem, não é perfeitamente caracterizado pelos ensaios da Mecânica dos Solos Convencional. Os blocos estruturados já apresentam certa resistência à desintegração quando imersos em água, podendo originar blocos menores que se mantém inalterados. Pela ação manual formam fragmentos menores.

\section{- Saprolito Duro ou Saprolito Grosso - III (Rocha Moderamente Alterada)}

Em comparação com o horizonte anterior, apresenta uma maior presença de blocos rochosos substancialmente mais resistentes que os primeiros, ou seja, em menor 
grau de alteração. A matriz de finos apresenta-se, no geral, sob forma de fração arenosa bem graduada, com eventual presença de silte e ausência de fração de argila. Neste material a matriz de finos não necessariamente envolve totalmente os blocos alterados. Blocos imersos em água permanecem, geralmente, inalterados. Resultados de RQD situam-se em uma faixa variável de 0 a 50 \%. Fragmentos são dificilmente quebrados pela ação manual. Quando compactados os saprolitos duros dão origem a maciços bastante permeáveis, uma vez que o manuseio mecânico deste material conduz a uma composição granulométrica predominantemente pedregulhosa, que apresenta um comportamento semelhante aos enrocamentos compactados.

\section{- Rocha Dura, Pouco a Mediamente Alterada - II (Rocha Pouco Alterada)}

Sob o horizonte de saprolito aparece a rocha com pequeno grau de alteração, resumindo-se, praticamente, a uma intemperização ao longo das fraturas existentes no maciço. Para sua utilização torna-se necessário, normalmente, recorrer-se a desmontes com explosivos.

Resultados de RQD indicam, normalmente, uma variação entre 50 e 75 \%. Fragmentos não são mais quebrados em suas bordas pela ação manual.

\section{- Rocha SÃ - (I)}

Parte final do perfil. Rocha sã que praticamente não apresenta intemperização, estando totalmente preservada. Esporadicamente pode-se notar pequenas intemperizações ao longo das maiores fraturas e fissuras. RQD normalmente superior a $75 \%$, valores médios da ordem de $90 \%$.

\subsection{Fatores que interferem no comportamento tensão-deformação e resistência de solos residuais}

\subsubsection{Introdução}

Há claras diferenças entre os fatores que influenciam o comportamento dos solos residuais e dos solos transportados. Nos solos transportados as partículas são pré formadas, transportadas por algum agente de transporte e depositadas de uma certa maneira. O solo é então submetido a um aumento de tensão efetiva devido ao aumento de tensão normal (vertical) e, algumas vezes, submetido a um subseqüente decréscimo devido a remoção do solo sobrejacente (pré - adensamento). Em um caso especial de argilas depositadas em suspensão em água, esta história de tensão determina totalmente 
a porosidade e o acondicionamento da partícula. A mecânica dos solos clássica tem sido desenvolvida para materiais particulares com propriedades totalmente originadas da porosidade inicial e subsequente do histórico de tensões, como são os solos sedimentares. O histórico de tensões nos solos sedimentares é muito importante pois modifica o condicionamento inicial do grão, causando o efeito de pré-adensamento.

A situação do solo residual, desenvolvido em situ sem transporte, é muito diferente. As partículas e seu arranjo evoluem progressivamente como uma consequência do intemperismo químico, com ampla variedade mineralógica e índices de vazios. Conforme Vaughan (1988), já comentado no capítulo anterior, o efeito de tensões prévias para o qual estes solos foram submetidos durante a sua formação será pequeno.

Pelo fato de os princípios da mecânica dos solos terem sido desenvolvidos para solos sedimentares, eles são freqüentemente inapropriados para solos residuais e causam resultados confusos quando eles são aplicados para estes materiais. Os solos residuais exibem propriedades e características especiais as quais diferem daquelas encontradas em solos sedimentares como um resultado do papel predominante do intemperismo na genesis do solo. Assim elas são aplicáveis para todo o perfil de intemperismo, não simplesmente para camadas superiores completamente intemperizadas. Serão abordadas algumas características que afetam o comportamento tensão versus deformação dos solos residuais, através de trabalhos que investigam a influência destas características no comportamento do solo. Serão relatados alguns trabalhos que procuram, através de ensaios de laboratório, entender um perfil de solo residual (maduro e jovem) tanto do ponto de vista de resistência quanto de deformabilidade.

Brener et al. (1997) lista as características especiais encontradas em solos residuais responsáveis pela diferença no comportamento tensão-deformação e na resistência em comparação com solos transportados. Segundo este autor estas características são: histórico de tensões, resistência do grão ou partícula, união ou vínculo entre as partículas (cimentação), estrutura reliquear e descontinuidades, anisotropia, indice de vazios e densidade, condição não saturada. A seguir será feita uma comparação baseada em Brener et al. (1997), a respeito da influência de cada uma destas características tanto no comportamento de um solo residual, como no comportamento de um solo transportado.

Quanto o histórico de tensões, conforme comentado anteriormente, percebe-se que sua influência no comportamento de solos residuais, desde que após sua formação 
ele não receba nenhum tipo de carregamento, é insignificante por causa do processo de formação destes solos (intemperismo). Vaughan (1988) afirma que o efeito de tensões prévias as quais os solos residuais tinham sido sujeitos durante sua formação será pequeno. Segundo este autor haverá um descarregamento vertical menor que o descarregamento horizontal, e durante o intemperismo estes descarregamentos anulam qualquer efeito de tensões prévias, estando a atual estrutura do solo residual em equilíbrio e associada ao seu atual estado de tensões. Nos solos transportados a sua influência já é muito grande pois ele modifica o condicionamento do grão, e causa o efeito de pré-adensamento.

A resistência do grão ou das partículas é muito variável nos solos residuais devido ao intemperismo que produz grãos ou aglomerados de grãos com vários graus de enfraquecimento e variada mineralogia. Nos solos sedimentares a resistência destas particulas ou grãos é mais uniforme e poucos grãos enfraquecidos são encontrados, porque as partículas fracas tendem a serem eliminadas durante o transporte.

A união ou vínculo entre partículas (cimentação), nos solos residuais é uma importante componente da resistência devido ao vínculo ou cimentação que é estabelecido entre partículas. Esta união, que pode ser facilmente destruída pela pertubação, causa intercepto de coesão e resulta em uma tensão de cedência. Nos solos sedimentares (transportados), com idade geológica, verifica-se o mesmo efeito. No item adiante será dada uma ênfase maior a este assunto (Estrutura cimentada) onde se explica sua influência no comportamento tensão-deformação e resistência de solos residuais.

Estrutura reliquear e descontinuidades em solos residuais desenvolvem-se da estrutura pré-existente ou das características estruturais da rocha matriz, incluindo estratificação, juntas, superfície polida e estriada resultante do atrito desenvolvido ao longo de um plano de falha, etc. Nos solos sedimentares estas são desenvolvidas pela deposição cíclica e a partir do histórico de tensões, sendo que superfícies polidas e estriadas resultante do atrito desenvolvido ao longo de um plano de falha podem estar presente (Blight, 1997).

Anisotropia em solos residuais geralmente é derivada do arranjo estrutural da rocha matriz, como exemplo tem-se as estratificações que na maioria das vezes aparecem nos solos residuais saprolíticos. Esta característica será abordada posteriormente através de alguns trabalhos realizados que mostram a relevância de se considerar a influência desta característica nas propriedades de resistência e 
deformabilidade de solos residuais derivados de gnaisse. Em solos sedimentares esta característica é derivada da deposição e do histórico de tensões.

Índice de vazios ou densidade em solos residuais depende do estado alcançado pelo processo de intemperismo e independem da história de tensões. Nos solos sedimentares os índices de vazios ou densidade são dependentes diretamente do histórico de tensões.

Outra característica importante em solos residuais, é que na maioria das vezes eles se encontram em condições parcialmente saturadas, onde o principal fator para que isto ocorra são as condições climáticas às quais estes solos são submetidos. No item solos não saturados será abordado este assunto, onde serão apresentados os principais conceitos e alguns trabalhos sobre resistência e deformabilidade de solos nestas condições.

\subsubsection{Estrutura cimentada}

\subsubsection{Introdução}

A estrutura de um solo residual é em grande parte o resultado do processo de intemperismo pelo qual o solo é formado. A estrutura freqüentemente envolve uma ampla faixa de tamanho de poros, alguns sendo tão grandes que normalmente seriam associados com o tamanho dos grãos do solo.

Um importante fator de influência no comportamento geotécnico dos solos residuais seria a presença de uma estrutura fracamente cimentada, descrita por Vaughan (1985, 1988) como: “uma componente da resistência e rigidez que é independente da tensão efetiva e porosidade e que se comporta como se fosse devida à conexões físicas entre partículas”.

Segundo Newill (1961) e Wallace (1973), em solos com moderados graus de intemperismo, alguma cimentação pode ser herdada da rocha mãe, mas em solos residuais completamente intemperizados ela é mais comum de ser devido a efeitos de cristalização, alteração mineral e a precipitação de material cimentante durante o intemperismo.

Segundo Vaughan (1988), as possíveis causas de vínculo entre partículas são:

a) Cimentação através da deposição de carbonatos, hidróxidos, matéria orgânica, etc; 
b) Solução e re-precipitação de agentes cimentantes, tais como silicatos;

c) Crescimento desta união durante a alteração química dos minerais.

Diversos pesquisadores, Costa Filho et al. (1989), Lerouel \& Vaughan (1990), Maccarinni et al. (1989), Vaughan (1985) e Vaughan et al. (1988) consideram a cimentação entre partículas como uma componente importante na resistência destes solos.

Segundo Vaughan (1985) a presença de cimentação pode revelar ao solo as seguintes características:

a) A presença do intercepto de coesão, c’, ( e alguma resistência drenada não confinada) em solos residuais saturados;

b) A presença de uma “pressão aparente de pré-adensamento” (Vargas, 1953) não relacionada com a história de tensões ou densidade; e

c) Resposta rígida a baixas tensões confinantes e comportamento mais plástico, a maiores tensões, caracterizando uma superfície de plastificação.

No entanto Wesley (1990) diz ser questionável se um valor real da coesão efetiva está necessariamente relacionado com a presença de ligações ou cimentações entre partículas. Amostras de solos residuais testadas pelo referido autor mostraram significantes valores de c', tanto no estado indeformado como no desestruturado. Aspectos de comportamento de campo desses materiais, quando usados na construção de terraços nos campos de arroz da Indonésia, reforçam esta hipótese. Estes terraços são formados parte por solo indeformado e parte por solo recompactado. Sua retro-análise mostrou a necessidade de um valor significativo de c’ para assegurar a estabilidade. É improvável que haja alguma contribuição da sucção, devido ao seu estado permanentemente saturado.

Estas cimentações no entanto podem ser perdidas devido a pertubação, tanto devido a amostragem como na própria execução dos testes em laboratório. O que vem se tornando cada vez mais aparente é que esta conexão física entre partículas é comum a muitos solos naturais in-situ de idade geológica, e tem sido identificada em argilas moles, argilas rijas, areias e solos residuais por diversos pesquisadores (Mitchell \& Solymar, 1984; Daramola, 1980; Vargas, 1953; Vaughan, 1985; Leroueil \& Vaughan, 1990). 
Vaughan (1985) relata que os solos residuais lateríticos e saprolíticos em particular apresentam um comportamento determinado principalmente pela estrutura formada pelo processo de intemperismo. Apesar destes solos serem de natureza bastante diversa, estes apresentam algumas características similares, dentre as quais, alta permeabilidade, uma envoltória de resistência apresentando um significante intercepto de coesão e uma tensão de escoamento (ou cedência) separando um comportamento mais rígido de um mais compressível.

A seguir são relacionadas algumas propriedades similares apresentadas por alguns solos residuais derivados de sua estrutura (Vaughan, 1985).

a) Permeabilidade - A permeabilidade dos solos residuais é tipicamente alta, resultado das agregações de partículas elementares de argila e de outras características microestruturais. Com efeito, o processo de intemperismo destes solos reúne em fortes vínculos partículas elementares de argila (de pequeno diâmetro), de modo que estas passam a se comportar como grãos de silte ou areia, gerando os macro-poros (espaços existentes dentro das agregações) destes solos. Por conta das agregações de partículas elementares, Vilar et al. (1985) relatam valores de coeficiente de permeabilidade de cerca de $10^{-4} \mathrm{~cm} / \mathrm{s}$ para um solo coluvionar laterizado, apesar da fração argila existente neste solo ser superior a $15 \%$. A permeabilidade apresentada por estes solos deve diminuir com a compressão do mesmo, contudo, esta redução não é significativa para a faixa de sobrecargas geralmente imposta por obras correntes de engenharia.

b) Resistência e compressibilidade - As envoltórias de resistência dos solos residuais apresentam geralmente um alto intercepto de coesão, a despeito de seu peso específico. Este elevado intercepto de coesão pode originar-se na sucção matricial do solo em campo, já que devido à sua alta permeabilidade estes se encontram geralmente não saturados, ou devido a cimentações geradas durante o processo de intemperismo ou laterização.

Os solos residuais apresentam uma pressão de pré-adensamento virtual (independente de sua história de tensões) quando carregados em oedômetro, de uma maneira similar aos solos sedimentares pré-adensados. Estes exibem um comportamento 
rígido quando submetidos a valores de pressão menores do que a pressão de adensamento virtual, apresentando alta compressibilidade para valores maiores.

Existe praticamente um consenso na afirmação de que a existência de um alto valor de intercepto de coesão e da pressão de pré-adensamento virtual é devida à gênese destes solos, aliada à sua condição não saturada, ou seja, devida às ligações existentes entre as partículas, geradas durante o processo de intemperismo e fortalecidas pela sucção matricial.

\subsubsection{Aspectos da reologia dos Solos Estruturados}

Vargas (1953) apresentou um trabalho pioneiro sobre o comportamento de solos residuais. A Figura 2.6 mostra curvas típicas obtidas de ensaios oedométricos em solos residuais brasileiros.

Este autor observou que a curva e $\mathrm{x} \log \sigma_{\mathrm{v}}$ de uma amostra indeformada de solo residual guarda certa semelhança com a conhecida curva de compressão das argilas sedimentares sobre - adensadas, no sentido de que se compõe basicamente de dois trechos, nos quais a deformabilidade do material é nitidamente distinta. Ao passar do primeiro para o segundo trecho, o solo perde rigidez, sofrendo cedência. Mas os comportamentos similares desses solos possui origens diferentes. Nas argilas sedimentares, está associado ao fenômeno do sobre-adensamento, ou seja, a tensão na qual se observa cedência corresponde à máxima tensão efetiva vertical a que esteve submetido esse solo ao longo de sua história geológica. Nos solos residuais isso não acontece, porque as tensões de cedência não se relacionam com as tensões de peso próprio atuais ou antigas, pelo menos até certa profundidade. Foram denominadas por Vargas de pressão de pré-adensamento virtual. A cedência, nos solos residuais, está associada à quebra da estrutura cimentada (Vaughan, 1985). 


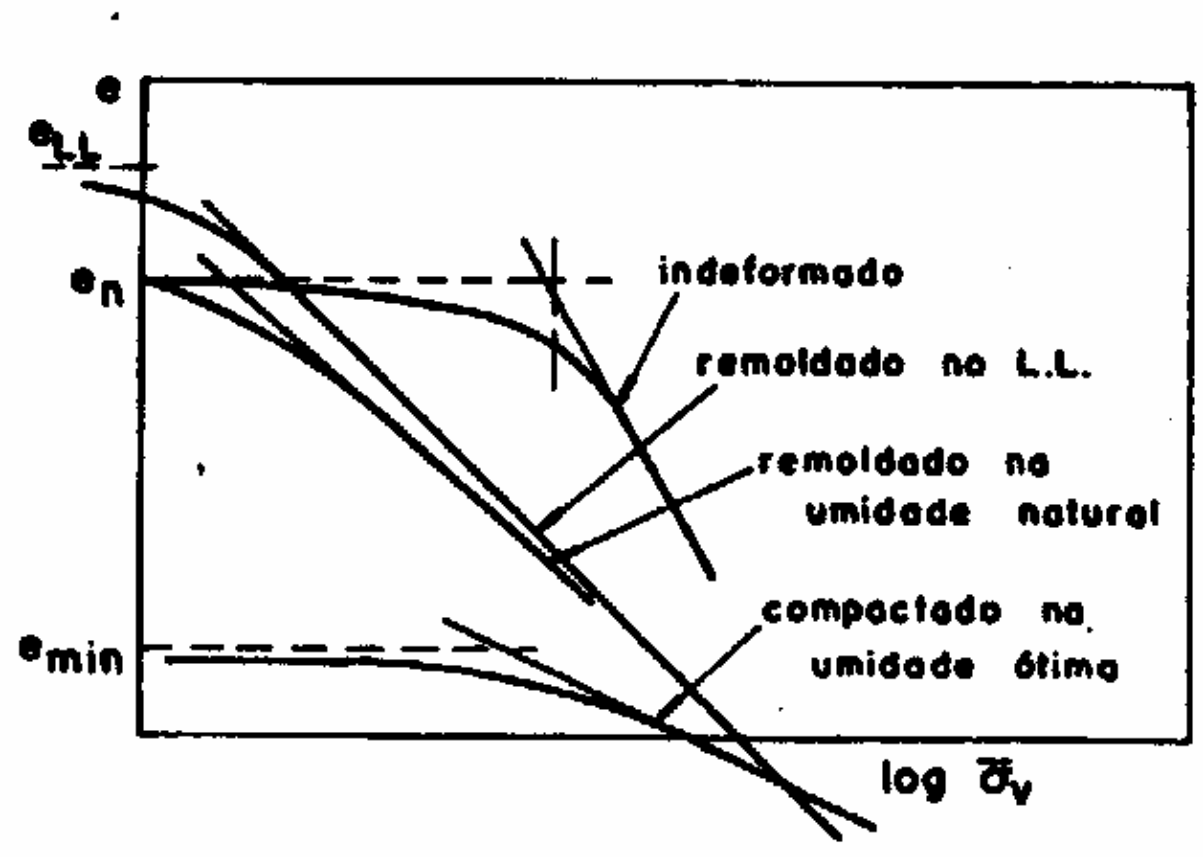

Figura 2.6 - Curvas típicas, obtidas de ensaios oedométricos em solos brasileiros (VARGAS, 1953).

Sendo as cimentações dos solos residuais relativamente fracas, suas propriedades são ditadas em equivalente grau por sua natureza particulada e sua estrutura cimentada (Vaughan, 1985), colocando-se, assim, entre dois extremos os solos não estruturados e as rochas mais duras. Por outro lado, isto os aproxima dos solos sedimentares estruturados e de algumas rochas brandas conforme mostraram Leroueil \& Vaughan (1990). Estes autores destacaram a forte similaridade existente no comportamento mecânico desses materiais.

A Figura 2.7 mostra a conexão entre cedência e resistência para ensaios oedométricos e triaxiais (Vargas, 1973).

Um exemplo da resistência como função da cimentação ao invés da densidade ou dilatação é mostrado na Figura 2.8; Segundo Vaughan (1988) em baixas pressões de confinamento a resistência de pico é alcançada enquanto a amostra está ainda contraindo, não no ponto onde a taxa de dilatação é máxima, como teria sido o caso com solo não cimentado ou com uma areia compacta. 


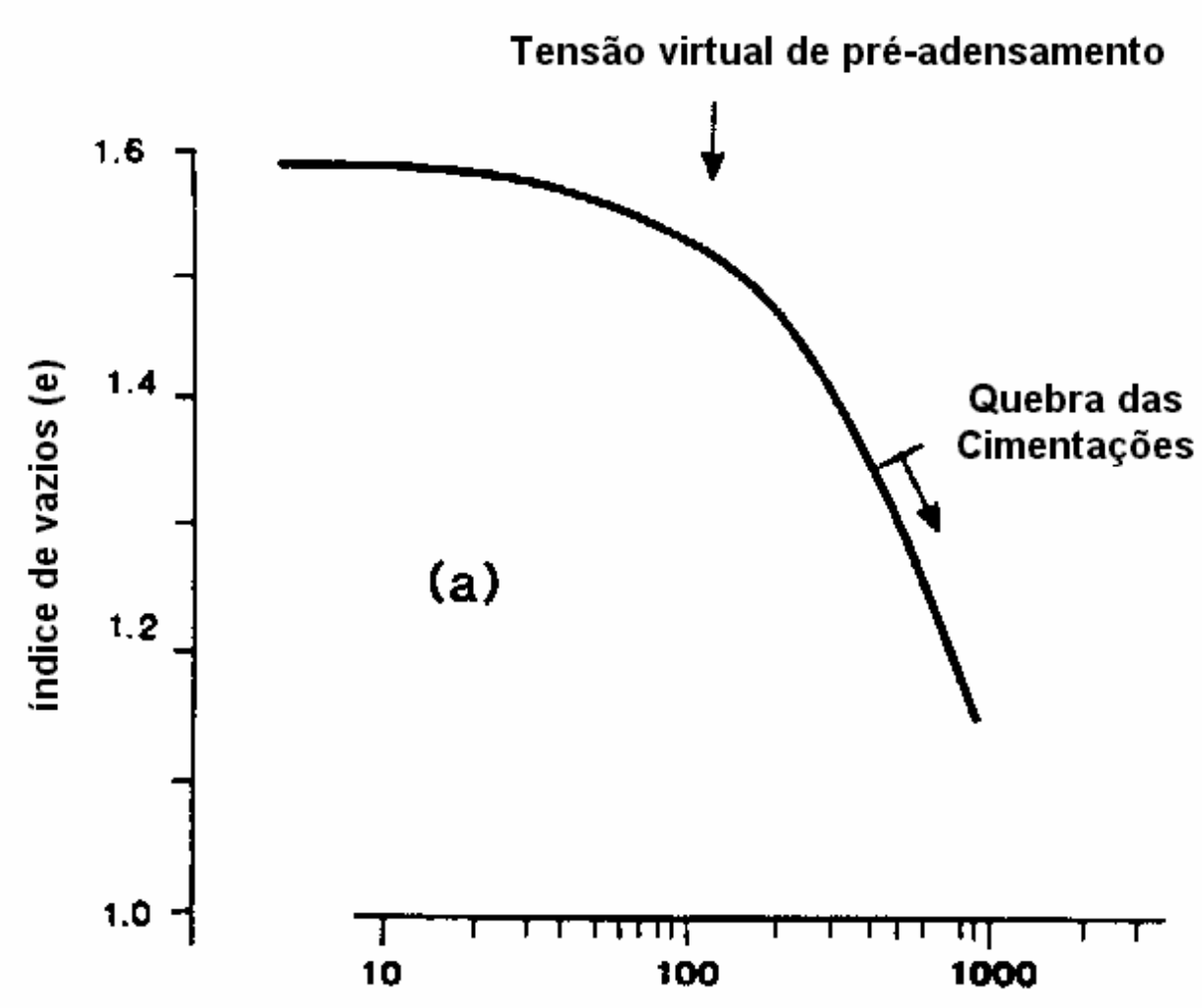

Tensão Vertical $\sigma_{\mathrm{v}}(\mathrm{kPa})$

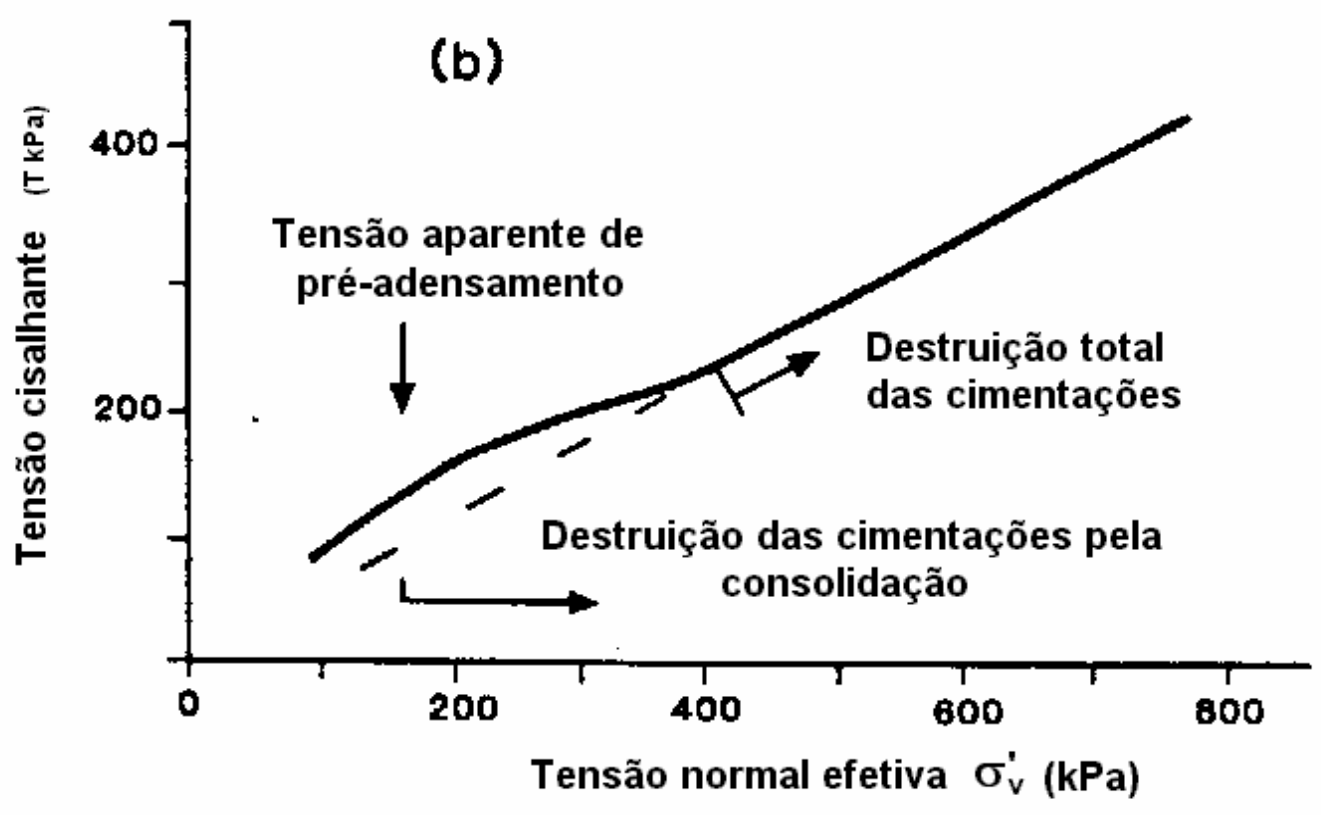

Figura 2.7 - Tensão aparente de pré - adensamento (Vargas 1973): a) Observada em oedômetro; (b) influência na resistência drenada em cisalhamento direto. 

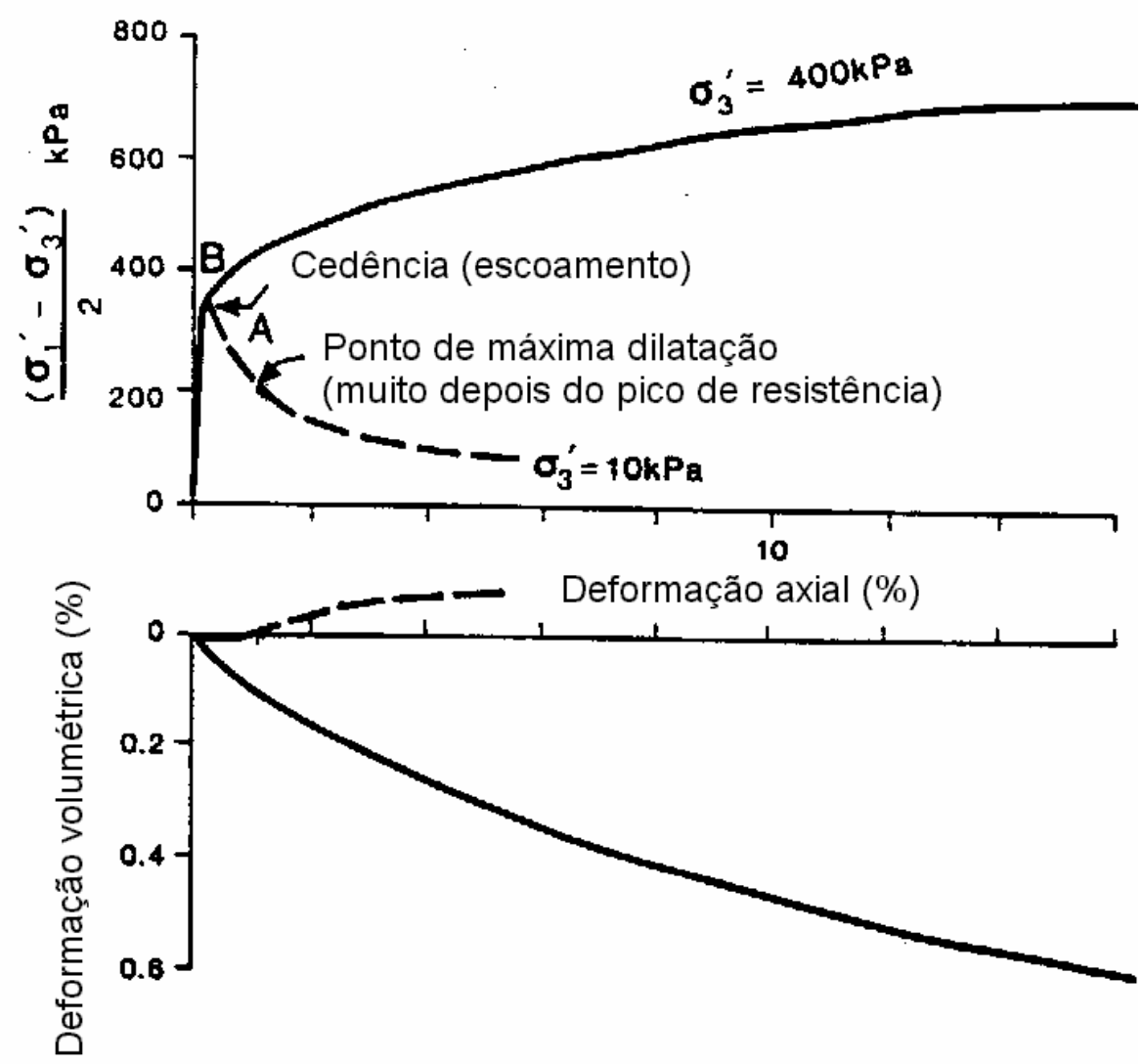

Figura 2.8 - Testes triaxiais drenados em solo residual de basalto (Vaughan, 1988).

O padrão de comportamento dos solos residuais idealizado por Vaughan e colaboradores teve influência do trabalho de Sangrey (1972) sobre argilas sedimentares cimentadas do Canadá que será comentado a seguir.

A Figura 2.9 mostra a curva obtida em ensaio oedométrico na argila de Mattagami Mines (Sangrey, 1972). O comportamento é típico de solos sensitivos. Há uma brusca queda do índice de vazios (cedência) quando a tensão aplicada ultrapassa 1 $\mathrm{kgf} / \mathrm{cm}^{2}$ (tensão de cedência) e este não se relaciona com a pressão de préadensamento $(\mathrm{Pa})$ que é bem menor. Em seguida a curva tende à de solo desestruturado. O que se percebe é que a cedência está associada a quebra das cimentações. 


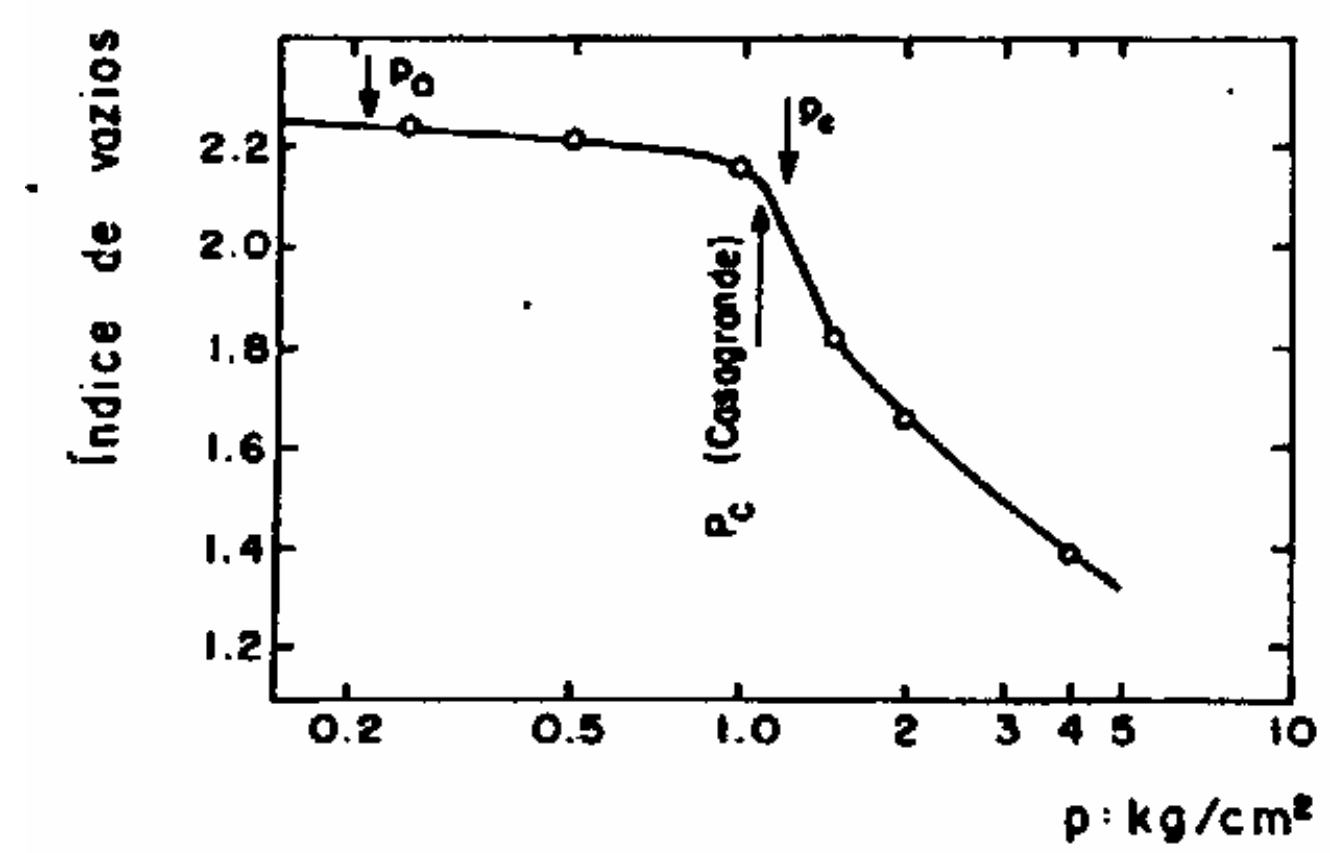

Figura 2.9 - Curva de compressão confinada para uma argila sedimentar cimentada (Sangrey, 1972).

Sangrey (1972) executou também ensaios triaxiais com amostras de argila do Labrador que forneceram a base para seu modelo. A Figura 2.10 se refere a dois ensaios, em que as pressões de adensamento isotrópico foram de 1,05 Kgf / $\mathrm{cm}^{2}$ e 2,11 Kgf / $\mathrm{cm}^{2}$, para os corpos de prova LA7 e LA8, respectivamente. Ambas sendo menores que as tensões de cedência determinadas em ensaios oedométricos. As curvas tensão desviatória versus deformação revelam as respostas bem diferenciadas das duas amostras. Esse comportamento foi explicado anteriormente por Conlon (1966) e se resume no seguinte: as cimentações governam o comportamento do material quando as tensões confinantes são baixas (LA7). Após o pico de resistência (a), associado à destruição das cimentações, a resistência por atrito não é suficiente para permitir o aumento de tensão desviatória e têm-se a queda da curva. No caso da amostra LA8, a tensão confinante, sendo mais alta, é capaz de prover resistência por atrito, após a cedência das cimentações (c), suficiente para que a tensão desviatória continue a crescer até a ruptura. A Figura 2.11 mostra os pontos de cedência obtidos em diversos ensaios triaxiais na argila de Labrador, os quais formam a curva de cedência e também as trajetórias de tensões dos ensaios comentados. Observa-se que os pontos b e d correspondentes às resistências pós-cedência das amostras LA7 e LA8, respectivamente se alinham com a origem dos eixos, constituindo a envoltória de resistência do material desestruturado (Townsend et al., 1969). 

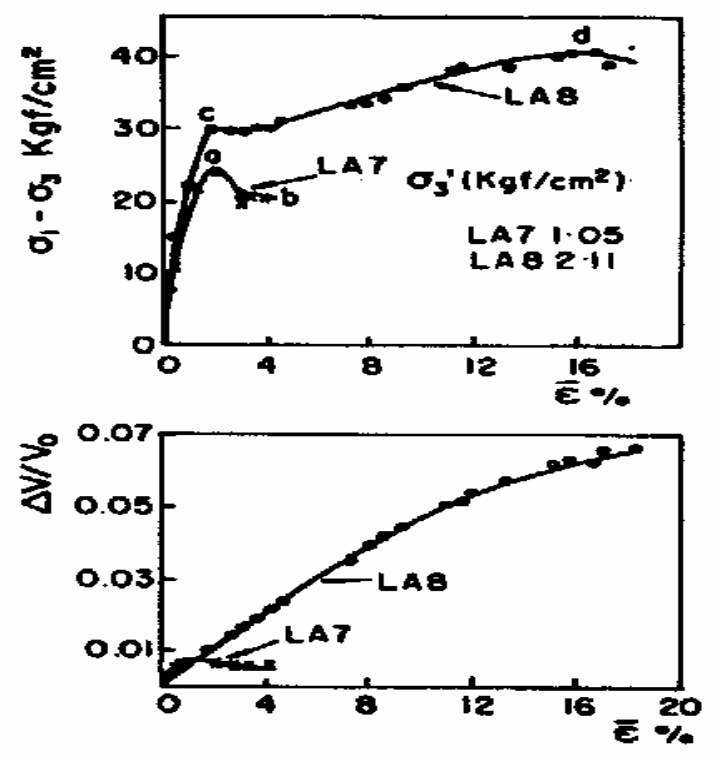

Figura 2.10 - Curva de Compressão triaxial executados em argilas sedimentares cimentadas ( Sangrey, 1972).

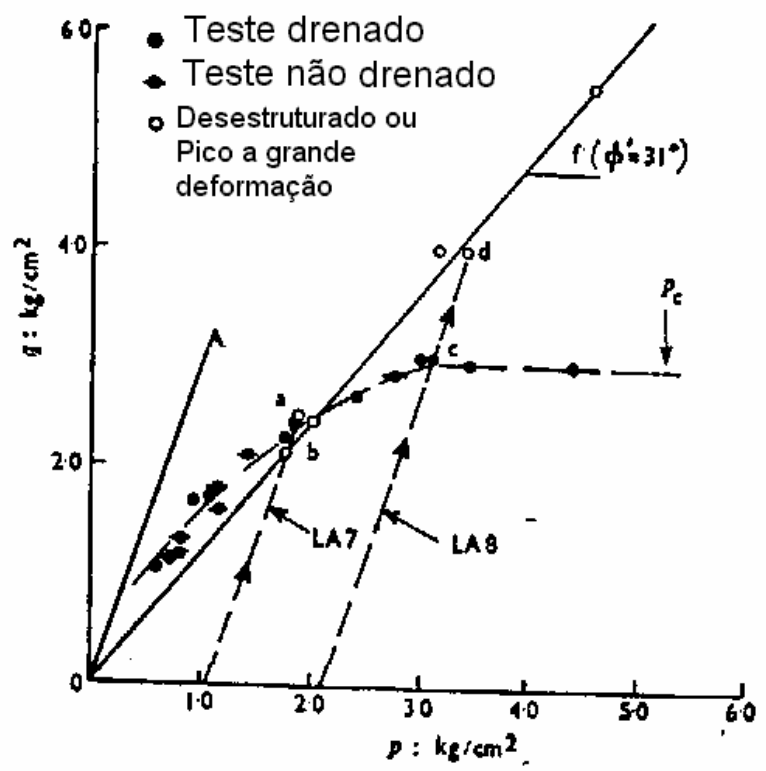

Figura 2.11 - Curva q versus p de testes de compressão triaxial, mostrando a cedência (Sangrey, 1972).

De acordo com o apresentado anteriormente, pode-se notar que se a cedência ocorrer durante a fase de compressão isotrópica de um ensaio triaxial (quando a tensão confinante supera a de cedência), durante o carregamento axial o comportamento será de material desestruturado. 
Leroueil \& Vaughan (1990) apresentam um resumo dos principais fatores afetando a forma da superfície de escoamento inicial de solos naturais. É mostrado que, para alguns solos, o efeito estrutura é tão importante na determinação do comportamento do solo quanto o seu índice de vazios inicial e a sua história de tensões. São apresentados os modos de como a compressão secundária e a cimentação podem afetar a forma e o tamanho das superfícies de plastificação de solos moles. Além disto, mostra-se que as superfícies de escoamento obtidas para as argilas naturais são mais ou menos centradas sobre a linha de compressão confinada (Figura 2.12), devido a sua estrutura anisotrópica. As argilas fortemente pré-adensadas tendem a exibir uma forma de superfície de plastificação semelhante. A estrutura destas argilas assim como a eventual presença de agente cimentante tende a elevar o valor da pressão de préadensamento. Conforme comentado anteriormente, por serem o produto da decomposição in situ da rocha mãe, os solos residuais sofrem uma menor influência do seu histórico de tensões em campo; Contudo tanto a cristalização associada com a formação de novos minerais quanto a precipitação de sais minerais acabam por promover vínculos inter-partículas que interferem no comportamento destes solos. Quanto às superfícies de escoamento obtidas para solos residuais, nota-se que elas tendem a ser centradas sobre a linha de compressão isotrópica (eixo p’) e não sobre a linha de compressão confinada (Figura 2.13). Apesar de que a estrutura dos solo em campo poderem se originar de diferentes causas, seus efeitos no comportamento do solo são similares. Deste modo o efeito da estrutura do solo em seu comportamento pode ser tratado em um único contexto, largamente independente da origem desta estrutura. A Figura 2.14 compara as superfícies de plastificação para argilas e solos residuais. 

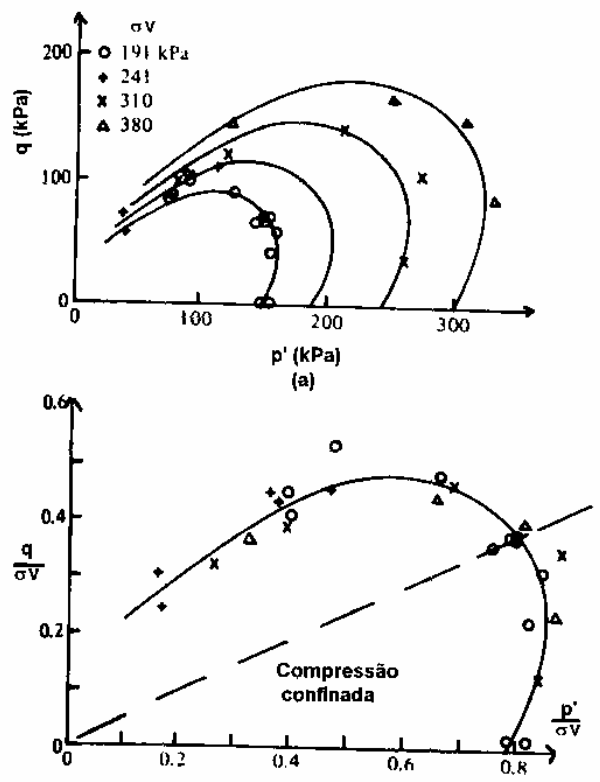

Figura 2.12 - Superfícies de escoamento obtidas a partir de ensaios triaxiais em amostras indeformadas de argila. (a) superfícies de escoamento no espaço q; p’ e (b) superfícies de escoamento normalizadas pela tensão vertical de campo. (Granhan et al., 1983).
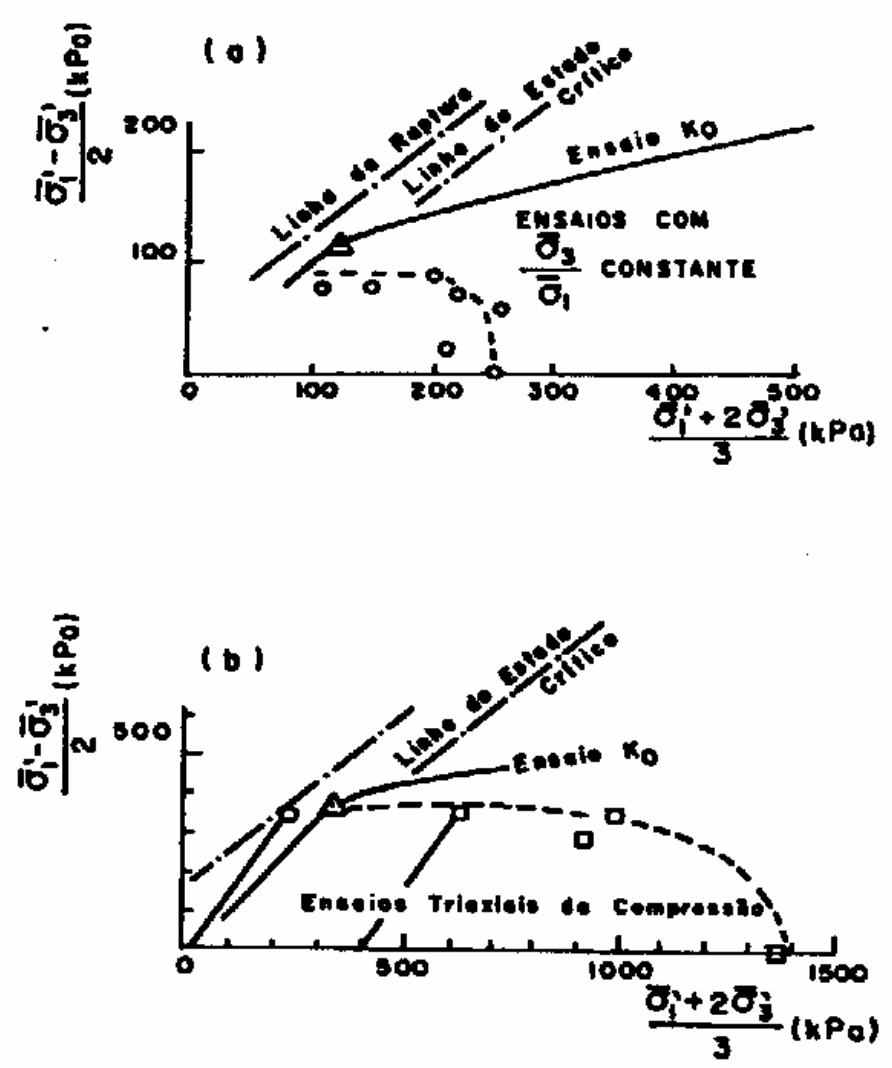

Figura 2.13 - Cedência (escoamento) observado em ensaios triaxiais realizados com solos residuais: a) Solo residual de gneisse (SANDRONI e MACCARINI, 1981); b) solo residual de basalto (Vaughan et al., 1988). 


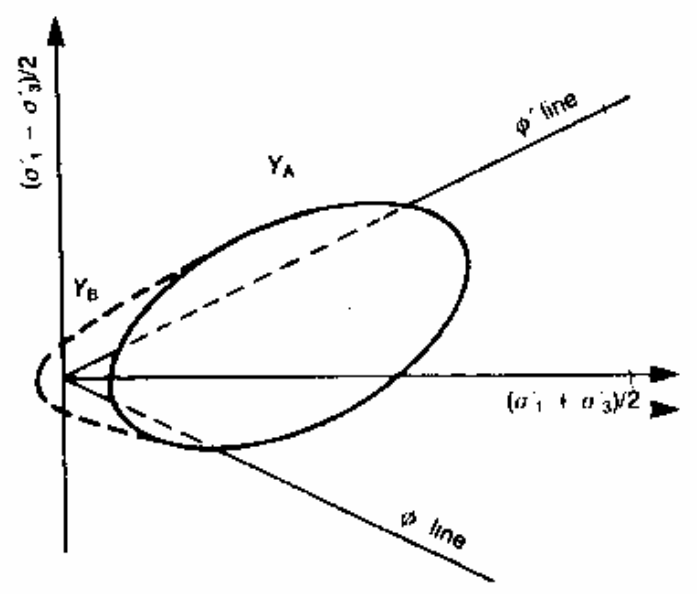

(a)

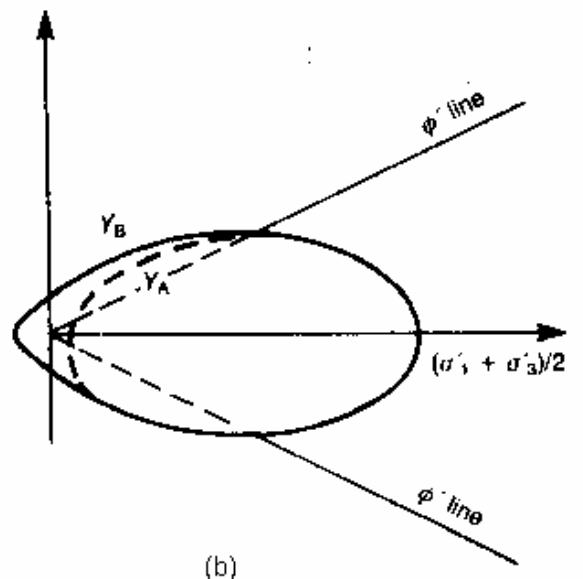

(b)

Figura 2.14 - Curvas de escoamento para solos estruturados: (a) anisotropia em argilas e (b) isotropia em algumas rochas moles e solos residuais (Leroueil \& Vaughan, 1990).

\subsubsection{3 - Identificação da Estrutura Cimentada}

A existência e a resistência de ligações diagenéticas não são fáceis de serem avaliadas. De acordo com Maccarini (1989) “a princípio, a dificuldade maior não é a aceitação da idéia da existência destas cimentações, mas sim, ter ao alcance técnicas e / ou modelos que permitem identificá-las e quantificá-las”.

Pode ser que a dificuldade em reconhecer os efeitos da estrutura cimentada em materiais fracos seja devida às dificuldades de amostragem. Segundo Vaughan (1988) dois outros fatores contribuem: primeiro, o estudo experimental sistemático da mecânica dos solos tem sido executado largamente usando amostras de solo reconstituídas, nas quais os efeitos da estrutura estão inevitavelmente ausentes. Segundo, no caso específico do solo residual, o efeito da saturação parcial e sucção, que é freqüentemente presente, fornece ao solo uma componente da resistência que é similar àquela dada pela estrutura cimentada, e que pode ser confundida com ela.

De acordo com Vaughan et al (1988), uma possível abordagem para identificação da estrutura cimentada, consiste em se comparar curvas de tensão efetiva versus índices de vazios, obtidas através de testes edométricos, no material intacto e no material remoldado (desestruturado) colocado em sua condição mais fofa. 
A curva obtida do solo desestruturado define no espaço tensão-índice de vazios a área admissível para o material desestruturado (Figura. 2.15). De acordo com os autores acima:

1) Qualquer que seja o grau de estruturação do material, grandes deformações plásticas não ocorrerão enquanto o solo permanecer na área estável ou admissível sugerida na Figura 2.15;

2) Somente a estrutura pode permitir ao solo sair da área estável definida pelo material desestruturado. Neste caso, o solo permanecerá rígido até que a plastificação ocorra; sendo o ponto de plastificação dependente da resistência da estrutura;

3) Com a plastificação desenvolvem-se grandes deformações. Quanto maior a diferença no índice de vazios entre o ponto de plastificação e a curva do material desestruturado, maior será a compressibilidade e a deformação potencial pós-plastificação do solo estruturado.

Wesley (1990) observou que para as amostras de uma argila vermelha tropical derivada do intemperismo de depósitos vulcânicos, os efeitos da estrutura parecem ser desprezíveis no seu comportamento, já que através de testes edométricos, notou-se que a curva do material remoldado é idêntica àquela do solo original. Desta maneira, a remoldagem não tem nenhum efeito no comportamento do solo (Figura. 2.16). O referido autor conclui: “As propriedades distintas de alguns solos residuais parecem refletir mais suas composições mineralógicas que qualquer efeito estrutural, como ligações entre partículas, e a influência da mineralogia não pode ser esquecida para se entender o comportamento dos solos residuais”. 


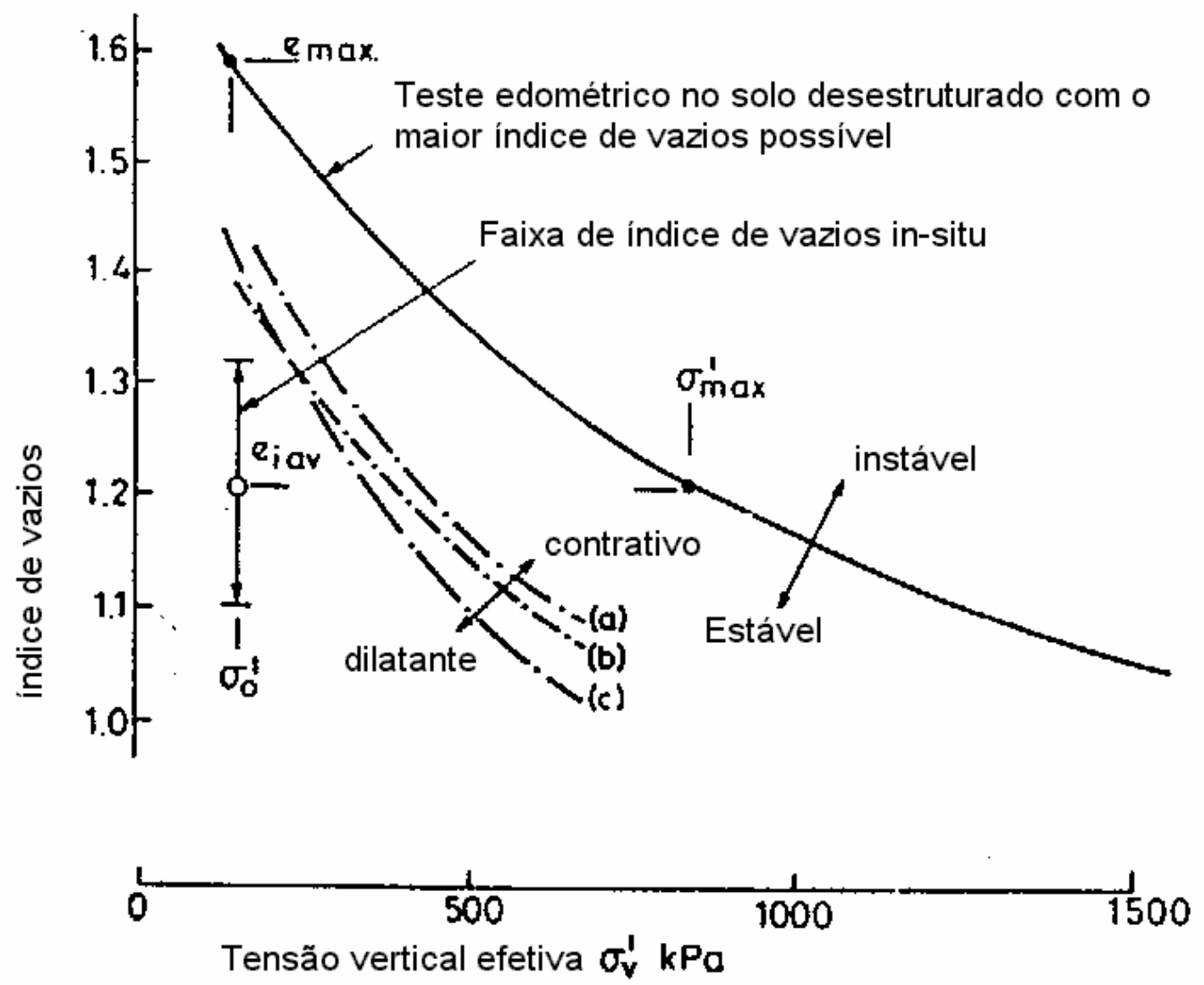

Figura 2.15 - Curva de compressão Edométrica de um Solo Residual de Basalto a Partir do Estado Inicial mais fofo possível (solo desestruturado) relacionada ao índice de vazios in-situ (Vaughan, 1985).

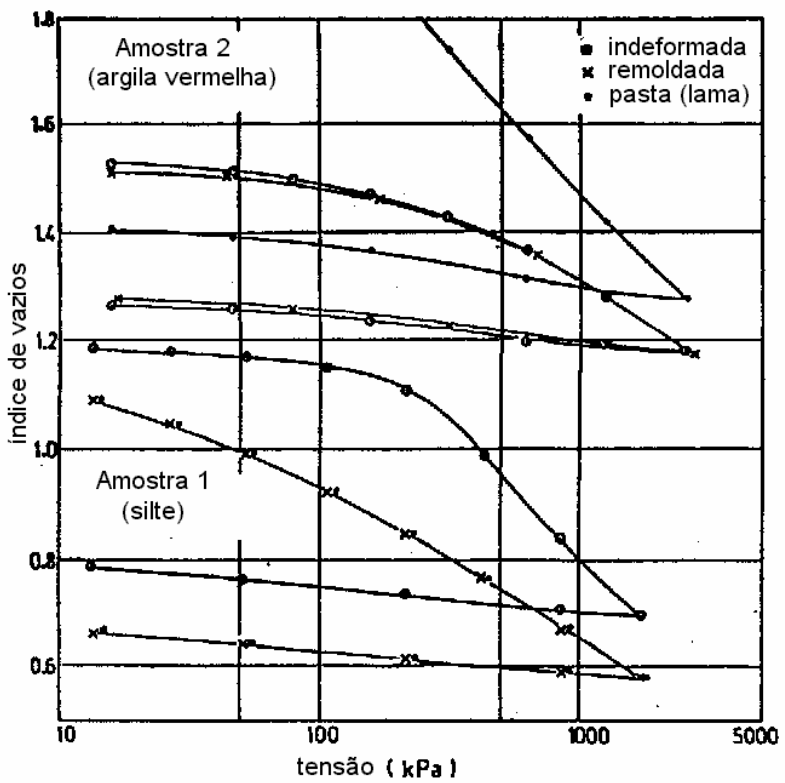

Figura 2.16 - Resultados de Testes Edométricos numa Argila Vermelha nos Estados Indeformado e Remoldado (Wesley, 1990). 
Vaughan et al (1988) apenas observaram que o ponto de plastificação numa curva de deformação de um solo estruturado é função da resistência de suas ligações e do índice de vazios inicial, não levando em conta o efeito da composição mineralógica no comportamento dos solos residuais. Os mesmos autores comentam que em materiais estruturados, o índice de compressão Cc, varia de acordo com a estrutura, ao invés de com a plasticidade ou granulometria, como no caso de solos não estruturados.

Outro indicador de uma possível cimentação em solos residuais, parece ser o fato de não haver nehuma relação entre a máxima pressão de campo e a pressão de préadensamento nestes solos (Vargas, 1953; De Campos, 1980; Maccarini, 1987). A razão para isso, segundo Maccarini et al. (1989), seria a presença de cimentações ligando as partículas dos solos residuais. A Figura 2.17 mostra a relação entre a pressão de campo e a pressão de pré-adensamento para um solo residual derivado de diabásio, apresentada pelos autores acima. Pode-se observar que a maioria dos valores da pressão de préadensamento é significativamente maior que a correspondente pressão de campo.

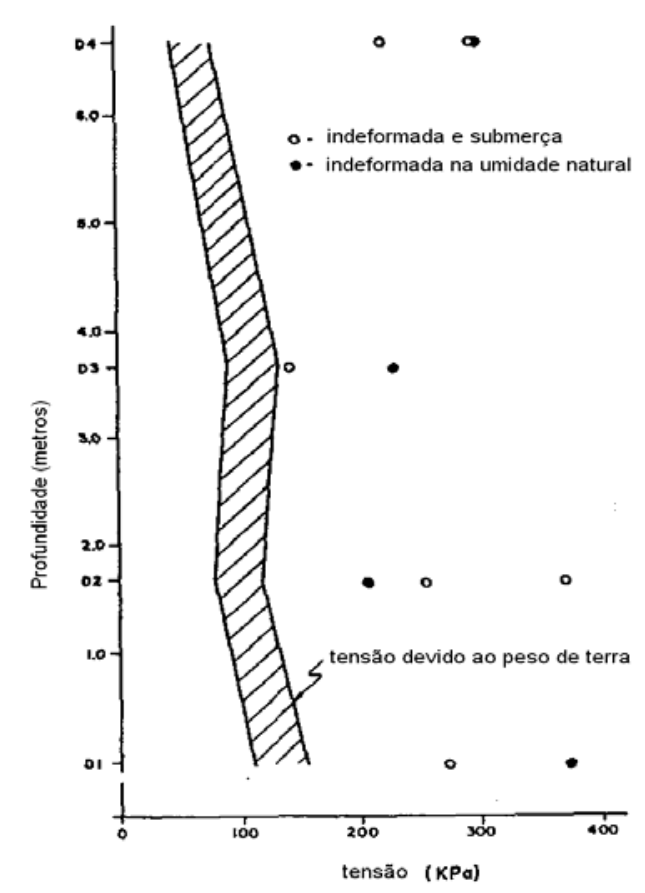

Figura 2.17 - Relação entre Pressão de Terra e Pressão Virtual de Pré-adensamento num Solo Residual de Diabásio (Maccarini, 1989). 
No entanto, De Mello (1972), observa que: “não há nenhuma razão para que as tensões in-situ em diferentes materiais sejam iguais à tensão média de campo. Pelo contrário, em analogia ao demonstrado pela mecânica das rochas, é possível e provável que as tensões iniciais de campo nos diferentes materiais sejam diferentes, possivelmente retendo alguma das tensões internas da rocha matriz.. A questão que é colocada é se a pressão virtual de pré-adensamento seria ou não uma revelação das tensões efetivas iniciais nos diversos materiais”.

\subsubsection{4 - Fatores que pertubam a estrutura cimentada}

Os fatores que podem destruir total ou parcialmente uma estrutura cimentada, conforme visto em diversos trabalhos da literatura mundial, como por exemplo a GEOLOGICAL SOCIETY ENGINEERING GROUP WORKING PARTY REPORTS (1990), relacionam-se:

- alívio de tensão;

- distúrbios mecânicos devido à amostragem;

- intemperismo

- técnicas de ensaio;

- remoldagem e desestruturação.

A amostragem envolve alívio de tensão total. As amostras, em solos residuais, são usualmente não-saturadas. Ainda que sejam saturadas, elas contêm poros de relativamente grandes dimensões. Assim, por uma ou outra razão, a tensão efetiva insitu não pode ser retida na amostra por capilaridade, como é possível em argilas sedimentares saturadas. Inevitavelmente existe uma larga redução na tensão efetiva principal acompanhando a amostragem, ainda que a mesma seja de alta qualidade. Isto pode permitir expansão, o que poderá causar perda de resistência da cimentação, resistência ao cisalhamento e rigidez e uma subestimativa destas propriedades in-situ. Segundo Sandroni (1985), “a expansão devido ao alívio de tensões rompe e desloca o complexo arranjo espacial dos grãos causando um "amolecimento” irrervesível da estrutura do solo. É provável que "ligações delicadas”, se presentes, sejam quebradas neste processo”. De acordo com Vaughan (1988), existem duas situações em que o efeito do alívio de tensões não é importante, quais sejam: 
- Quando as amostras são retiradas de uma profundidade muito pequena e o alívio de tensões é pequeno.

- Quando as amostras são retiradas da superfície de um talude que sofreu um corte, já que o solo é descarregado quando o talude é escavado por um valor similar àquele envolvido na amostragem; ou quando o solo perto da base da escavação de uma fundação é descarregado de um valor similar àquele devido à amostragem.

A amostragem para testes de laboratório pode envolver distúrbios mecânicos e uma perda potencial de estrutura.

O intemperismo físico tende a destruir a estrutura. O intemperismo químico pode destruir a estrutura, quando processos como a lixiviação de materiais cimentantes ocorrem. No entanto, o intemperismo químico pode também acrescentar à estrutura, quando, por exemplo, material cimentante é precipitado. Quando a desestruturação é causada pelo intemperismo, há um decrescimento da rigidez do material. Chandler (1972) observou que a deformação na ruptura em testes triaxiais numa argila crescia com o aumento do intemperismo.

Bressani \& Vaughan (1989) obsevaram que a resistência de um material fracamente cimentado, como supostamente o é o solo residual, é fortemente influenciada por técnicas experimentais de laboratório, como o método de saturação, trajetória de tensões seguida, e carregamento não uniforme. Em um estudo com solos de Hong Kong (GEOTECHNICAL CONTROL OFFICE HONG KONG 1982), apud Atkinson et al (1990), os autores verificaram que a resistência ao cisalhamento pode ser substimada se durante o teste a combinação de tensões cisalhantes e tensões efetivas médias causam cedência da estrutura cimentada e também verificaram que as trajetórias de tensões seguidas durante os ensaios influem na resistência e deformação do mesmo, pois dependendo da trajetória escolhida pode haver uma perda prematura de cimentação (vínculos) entre partículas.

A estrutura de um solo pode também ser destruída por remoldagem e “desestruturação”, ainda que a porosidade do mesmo não seja alterada. No entanto, a experiência mostra que ela pode se formar, ou se reformar, rapidamente, em questão de algumas semanas ou meses, no caso de solos sedimentares. No entanto, ligações entre partículas, como a cimentação em solos residuais, dependem de um tempo bastante maior para se desenvolverem, e é improvável que efeitos gerados na escala de tempo 
geológica, possam ser totalmente regenerados na escala de tempo de trabalhos de engenharia (Leroueil \& Vaughan, 1990).

\subsubsection{ANISOTROPIA}

\subsubsection{Introdução}

A anisotropia é um fenômeno que faz com que as características de resistência e deformação dos solos dependam da direção em que ocorre a solicitação. Casagrande \& Carrilho (1944) foram os primeiros a sugerirem uma distinção entre dois tipos básicos de anisotropia: inerente e induzida. No primeiro caso, ela se deve a orientação preferencial das partículas do solo durante o processo de formação do depósito, enquanto que no segundo caso, é uma conseqüência direta dos estados de esforços efetivos ao qual esteve submetido o depósito de solo depois de sua formação, ou seja, a qualquer outra causa que haja modificado a sua estrutura original.

Como resultado da anisotropia de tensões em um solo, a resposta da aplicação de tensões cisalhantes depende da direção das tensões. Segundo Brenner et al (1997), em solos transportados, o comportamento anisotrópico é diretamente associado com o modo de deposição e a história de tensões do depósito, e em solos residuais o comportamento anisotrópico tem geralmente sido herdado da rocha mãe, embora tensões em situ possa também desempenhar o papel.

Em muitas situações práticas, tais como, fundações, escavações, barragens, etc., é necessário conhecer as características de resistência e deformabilidade dos solos residuais freqüentemente encontrados no Brasil. Intuitivamente devido a sua heterogeneidade é esperado um comportamento anisotrópico destes solos. No entanto, esse comportamento anisotrópico não é geralmente assumido.

De modo a verificar a relevância de se considerar anisotropia nas características de resistência e deformabilidade dos solos, vários trabalhos tem sido realizados em areias e argilas, principalmente, e mais recentemente tem-se encontrados alguns trabalhos em solos residuais.

Para quantificar a anisotropia, várias técnicas têm sido propostas. Estudando a anisotropia da resistência não-drenada (Su) de argilas normalmente adensadas, através de ensaios de palheta, AAS (1965) introduziu a razão $\left(\tau_{\mathrm{f}}\right)_{\mathrm{h}} /\left(\tau_{\mathrm{f}}\right)_{\mathrm{v}}$ como uma medida de anisotropia. Aqui, $\left(\tau_{\mathrm{f}}\right)_{\mathrm{h}}$ e $\left(\tau_{\mathrm{f}}\right)_{\mathrm{v}}$ são as resistências cisalhantes nos planos horizontal e vertical respectivamente. Berre \& Bjerrum (1973) e Nakase \& Kamei (1986) 
expressaram a anisotropia como a razão da resistência na compressão em relação à extensão.

Neste ítem serão apresentados alguns trabalhos realizados sobre este tema, em areias, argilas e solos residuais.

\subsubsection{2 - Alguns trabalhos realizados}

Stankatt (1991), em sua tese de doutorado, realizou um estudo experimental do comportamento tensão-deformação, em argila adensada unidirecionalmente, após mistura com água. Para a execução do adensamento da argila foram desenvolvidos equipamentos para adensamento de grandes quantidades de lama, e medidores eletrônicos específicos para deformações volumétricas e radiais, usados em ensaios de compressão triaxial. O modelo da teoria clássica elasto-linear, para solos com comportamento anisotrópico é utilizado, após desenvolvimento algébrico, na obtenção dos parâmetros da argila. Nos cálculos, são aplicados processos estatísticos de regressões polinomiais. São analisadas as correlações dos parâmetros elásticos isotrópicos e anisotrópicos (Módulos de Elasticidade, Coeficiente de Poisson e Modulos de Elasticidade Transversal), com as tensões confinantes dos ensaios triaxiais, e com os índices de pré-adensamento OCR das lamas. Stankatt (1991) fez uma revisão sobre trabalhos que levam em consideração a anisotropia de argilas.

Em areias, estudos sobre anisotropia inerente foram realizados por diversos pesquisadores através de carregamentos de compressão em deformação plana (Arthur \& Assadi, 1977; Oda et al., 1978; Oda, 1981; Tatsuoka et al., 1986) e de extensão axissimétrica (Shankariash \& Ramamurthy, 1980). Em todos esses estudos as amostras foram preparadas por pluviação no ar ou na água. Este método reproduz adequadamente a sedimentação de areias em lagos e bacias, porém apresenta a desvantagem de possibilitar a segregação de partículas, caso o solo tenha um percentual elevado de finos.

Os métodos de deposição no ar ou na água, para a preparação de corpos de prova arenosos, exercem grande influência nas características de anisotropia inerente (Oda, 1972; Arthur \& Menzies, 1972; Arthur \& Assade, 1977; Oda et al, 1978; Yamada \& Yshira, 1979, 1981). Diversos trabalhos foram realizados com o objetivo de estudar as características anisotrópicas de areias, especialmente em amostras 
reconstituídas por pluviação (Arthur et al., 1981; Symes,1983; Negussey, 1984; Miura, 1985; Sayão, 1989)

Green \& Reades (1975) estudaram os efeitos da anisotropia nas características de tensão e deformação de areias através de ensaios de compressão triaxial e deformação plana. Os ensaios de deformação plana e de compressão triaxial na direção horizontal, realizados no equipamento triaxial desenvolvido por Green (1971), demonstraram que amostras fofas e densas são mais compressíveis na direção horizontal. No entanto, com relação à resistência, as areias ensaiadas por Green mostraram-se essencialmente isotrópicas. Yamada \& Ishihara (1979 e 1981) e Quaresma (1997), utilizando um equipamento triaxial cúbico, observaram os efeitos da anisotropia em amostras preparadas por deposição vertical. Quando carregadas verticalmente (ensaios de compressão axial), as amostras exibiam maior resistência à deformação do que quando carregadas lateralmente. As amostras fofas referidas nestes estudos foram preparadas por pluviação na água, e apresentaram índices de vazios elevados.

No caso de anisotropia induzida, a deformação está relacionada à tensão aplicada. Alguns trabalhos mostram o efeito da anisotropia induzida em amostras de areia submetidas a tensões cisalhantes na célula de cisalhamento direcional (Arthur et al., 1977; Arthur et al., 1980; Arthur et al., 1981).

Segundo Costa Filho \& Campos (1991), embora a microestrutura de solos residuais associados a um perfil de intemperismo seja relevante para a compreensão do comportamento em obras de engenharia, aspectos macroestruturais nos solos residuais jovens são, em muitos casos, de maior importância no que se refere ao comportamento de massas de solo. Os principais aspectos macroestruturais são:

- anisotropia estrutural associada com a rocha matriz;

- presença de estruturas reliquiares da rocha original, incluindo planos de fraqueza (resistência ao cisalhamento e deformabilidade) e veios permeáveis e impermeáveis (permeabilidade);

- fissuras, juntas e outros tipos de descontinuidades, polidas ou não;

- presença de furos no solo que poderiam ser associados com processos de laterizção, ação animal intensa, dutos formados por erosão interna de zonas frágeis, etc, provocando um aumento de permeabilidade na massa. 
Dentre esses aspectos macroestruturais pode-se dizer, que a anisotropia estrutural herdada de uma rocha matriz é comumente observada em solos residuais jovens derivados de rochas metamórficas (gnaisse, filito, ardósia, etc) e sedimentares (xisto argiloso, siltito, etc); e que este tipo de anisotropia é diferente da imposta à massa pela presença de aspectos reliquiares tais como camadas permeáveis e impermeáveis, camadas frágeis, etc.

Serão apresentados adiante alguns trabalhos que avaliam a relevância de se considerar anisotropia nas características de resistência e deformabilidade de solos residuais de gnaisse, freqüentemente encontrados no Brasil.

Maccarini (1980), usando um equipamento de cisalhamento direto, analisou em laboratório as características de anisotropia de um solo residual gnáissico jovem do campo experimental da PUC / Rio. Os ensaios foram realizados com o solo na umidade natural; o ângulo entre a superfície de ruptura e os planos de xistosidades do solo, $(\beta)$, foi fixado em $0^{0}, 45^{\circ}$ ou $90^{\circ}$. A Tabela 2.3 mostra os valores de coesão e ângulo de atrito encontrados para os diferentes valores de $\beta$.

Tabela 2.3 - Indice de vazios inicial, coesão e ângulo de atrito (Maccarini, 1980).

\begin{tabular}{|c|c|c|c|}
\hline $\begin{array}{c}\text { Ângulo entre a superfície de } \\
\text { ruptura e a xistosidade }(\beta)\end{array}$ & $\mathrm{e}_{\mathrm{o}}$ & $\begin{array}{c}\mathrm{c} \\
(\mathrm{kPa})\end{array}$ & $\begin{array}{c}\phi \\
\left({ }^{\circ}\right)\end{array}$ \\
\hline $0^{\circ}$ & 1,12 & 46 & 31,4 \\
\hline $45^{\circ}$ & 0,94 & 60 & 33,0 \\
\hline $90^{\circ}$ & 1,02 & 59 & 32,6 \\
\hline
\end{tabular}

Segundo Maccarini (1980), apesar da visível verificação dos planos de xistosidade do solo, os parâmetros de resistência do mesmo não foram significativamente afetados pelo ângulo $\beta$ (Tabela 2.3). Ainda nesta tabela observa-se que o ângulo de atrito apresenta uma pequena variação e enquanto a coesão apresenta um menor valor para a direção dos planos de xistosidade $(\beta=0)$. As curvas tensão cisalhante versus deslocamento obtidas indicaram uma deformação na ruptura menor para a direção dos planos de xistosidade, e que, quanto a resistência de pico, não houve uma predominância de qualquer direção sobre as demais. 
Costa Filho et al. (1989) observaram a ocorrência de anisotropia nos parâmetros de resistência ao cisalhamento em estudo realizado em solos saprolíticos oriundos de rochas metamórficas (Tabela 2.4).

Costa Filho \& Campos (1991), estudaram a anisotropia de um solo gnáissico jovem proveniente da região de Chapéu d’Uvas. Foram realizados ensaios de cisalhamento direto e oedométrico, ambos com corpos de prova na umidade natural e submersos, e também ensaios triaxiais com corpos de saturados. Para os ensaios oedométricos e de cisalhamento direto os corpos de prova foram moldados com seus eixos paralelos e perpendiculares à xistosidade, e para os ensaios triaxiais os corpos de prova foram moldados com a xistosidade na horizontal e inclinada de $45^{\circ}$ com a horizontal. As Figuras 2.18 e 2.19 mostram as envoltórias de resistência obtidas por regressão linear para os ensaios de cisalhamento direto e triaxial respectivamente; e a Figura 2.20 mostra os resultados dos ensaios oedométricos.

Tabela 2.4 - Parâmetros de resistência ao cisalhamento de solos residuais jovens derivados de rochas metamórficas (Costa Filho et al., 1989).

\begin{tabular}{|c|c|c|c|c|c|}
\hline \multirow[t]{2}{*}{$\begin{array}{l}\text { ROCHA } \\
\text { MATRIZ }\end{array}$} & \multirow[t]{2}{*}{$\begin{array}{c}\text { MACRO } \\
\text { ESTRUTURA }\end{array}$} & \multicolumn{2}{|c|}{$\begin{array}{c}\text { PARÂMETROS DE } \\
\text { RESISTÊNCIA DO TESTE DE } \\
\text { CISALHAMENTO DIRETO }\end{array}$} & \multirow{2}{*}{$\begin{array}{l}\text { CONDIÇÃO } \\
\text { DE } \\
\text { SATURAÇÃO }\end{array}$} & \multirow[t]{2}{*}{ REFERÊNCIA } \\
\hline & & PARALELO & PERPENDICULAR & & \\
\hline $\begin{array}{l}\text { Quartzito } \\
\text { Ferrítico }\end{array}$ & $\begin{array}{c}\text { Laminado } \\
\text { (silte arenoso) }\end{array}$ & $\begin{array}{c}c^{\prime}=20 \mathrm{kPa} \\
\phi^{\prime}=37^{\circ}\end{array}$ & $\begin{array}{c}c^{\prime}=50 \mathrm{kPa} \\
\phi^{\prime}=44^{\circ}\end{array}$ & $\begin{array}{c}\text { Parcialmente } \\
\text { Saturado }\end{array}$ & $\begin{array}{c}\text { Sandroni } \\
1985\end{array}$ \\
\hline $\begin{array}{l}\text { Quartzito } \\
\text { Micáceo }\end{array}$ & $\begin{array}{c}\text { xistoso } \\
\text { (areia siltosa) }\end{array}$ & $\begin{array}{c}c^{\prime}=40 \mathrm{kPa} \\
\phi^{\prime}=22^{\circ}\end{array}$ & $\begin{array}{c}c^{\prime}=45 \mathrm{kPa} \\
\phi^{\prime}=27^{\circ}\end{array}$ & $\begin{array}{c}\text { Parcialmente } \\
\text { Saturado }\end{array}$ & $\begin{array}{c}\text { Sandroni } \\
1985\end{array}$ \\
\hline \multirow[t]{2}{*}{$\begin{array}{c}\text { Gnaisse } \\
\text { Migmatítico }\end{array}$} & \multirow{2}{*}{$\begin{array}{l}\text { Em camadas } \\
\text { (camadas rica } \\
\text { em micas) }\end{array}$} & $\begin{array}{l}c^{\prime}=40 \mathrm{kPa} \\
\phi^{\prime}=22^{\circ}\end{array}$ & $\begin{array}{c}c^{\prime}=52 \mathrm{kPa} \\
\phi^{\prime}=23^{\circ}\end{array}$ & $\begin{array}{c}\text { Parcialmente } \\
\text { Saturado }\end{array}$ & $\begin{array}{c}\text { de Campos } \\
1974\end{array}$ \\
\hline & & $\begin{array}{l}c^{\prime}=30 \mathrm{kPa} \\
\phi^{\prime}=21^{\circ}\end{array}$ & $\begin{array}{c}c^{\prime}=49 \mathrm{kPa} \\
\phi^{\prime}=22^{\circ}\end{array}$ & Submerso & $\begin{array}{c}\text { de Campos } \\
1974\end{array}$ \\
\hline Xisto & $\begin{array}{c}\text { Laminado } \\
\text { (silte arenoso) }\end{array}$ & $\begin{array}{c}c^{\prime}=78 \mathrm{kPa} \\
\phi^{\prime}=28^{\circ}\end{array}$ & $\begin{array}{c}c^{`}=100 \mathrm{kPa} \\
\phi^{\prime}=27^{\circ}\end{array}$ & $\begin{array}{c}\text { Parcialmente } \\
\text { Saturado }\end{array}$ & $\begin{array}{c}\text { Durci e } \\
\text { Vargas (1983) }\end{array}$ \\
\hline $\begin{array}{c}\text { Filito } \\
\text { (micáceo) }\end{array}$ & $\begin{array}{l}\text { Xistoso } \\
\text { (silte) }\end{array}$ & $\begin{array}{c}c^{\prime}=10 \mathrm{kPa} \\
\phi^{\prime}=29^{\circ}\end{array}$ & $\begin{array}{c}c^{\prime}=60 \mathrm{kPa} \\
\phi^{\prime}=41^{\circ}\end{array}$ & $\begin{array}{c}\text { Parcialmente } \\
\text { Saturado }\end{array}$ & $\begin{array}{c}\text { Durci e } \\
\text { Vargas (1983) }\end{array}$ \\
\hline
\end{tabular}




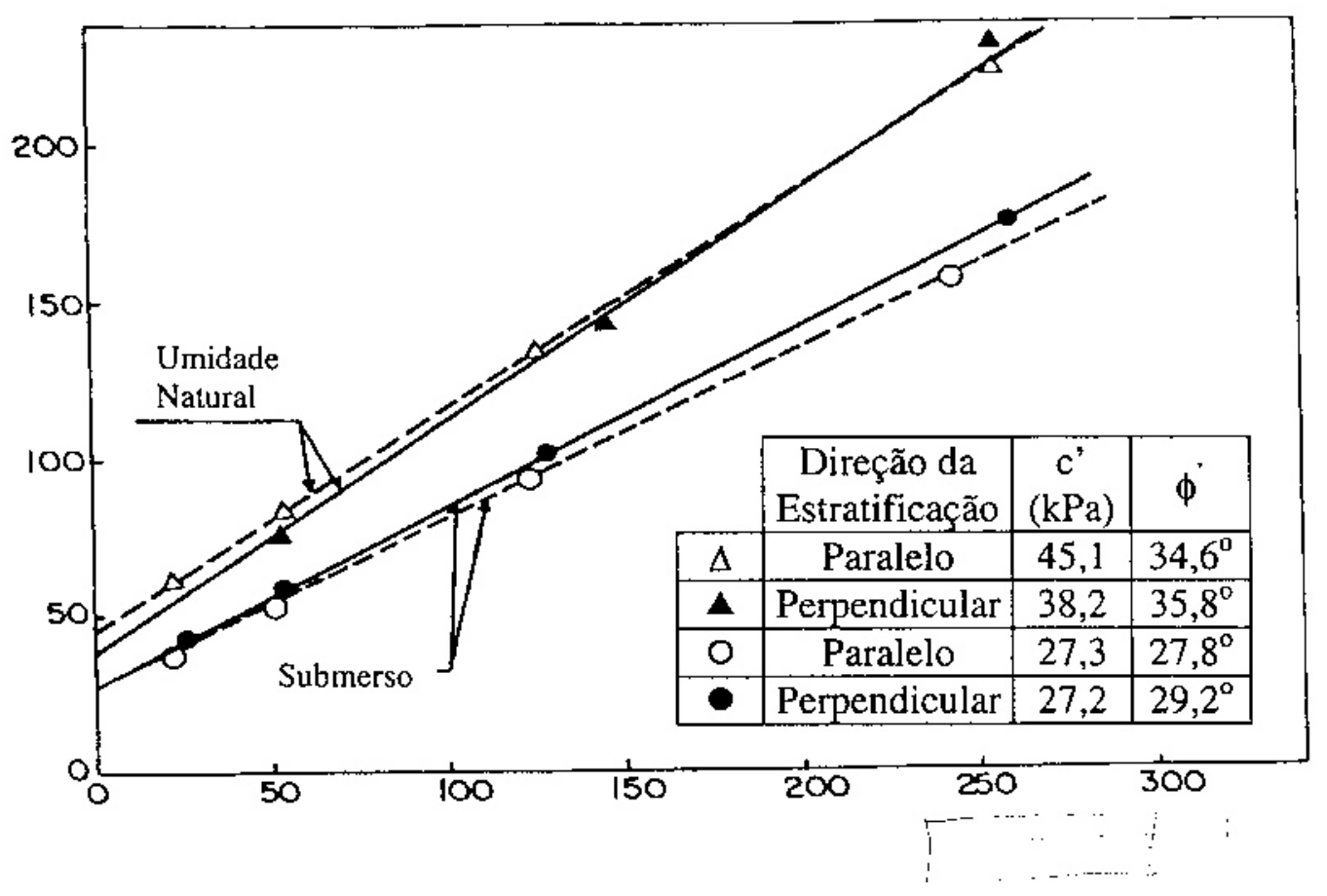

Figura 2.18 - Resultados dos ensaios de cisalhamento direto em solo gnáissico (Costa Filho \& De Campos, 1991).

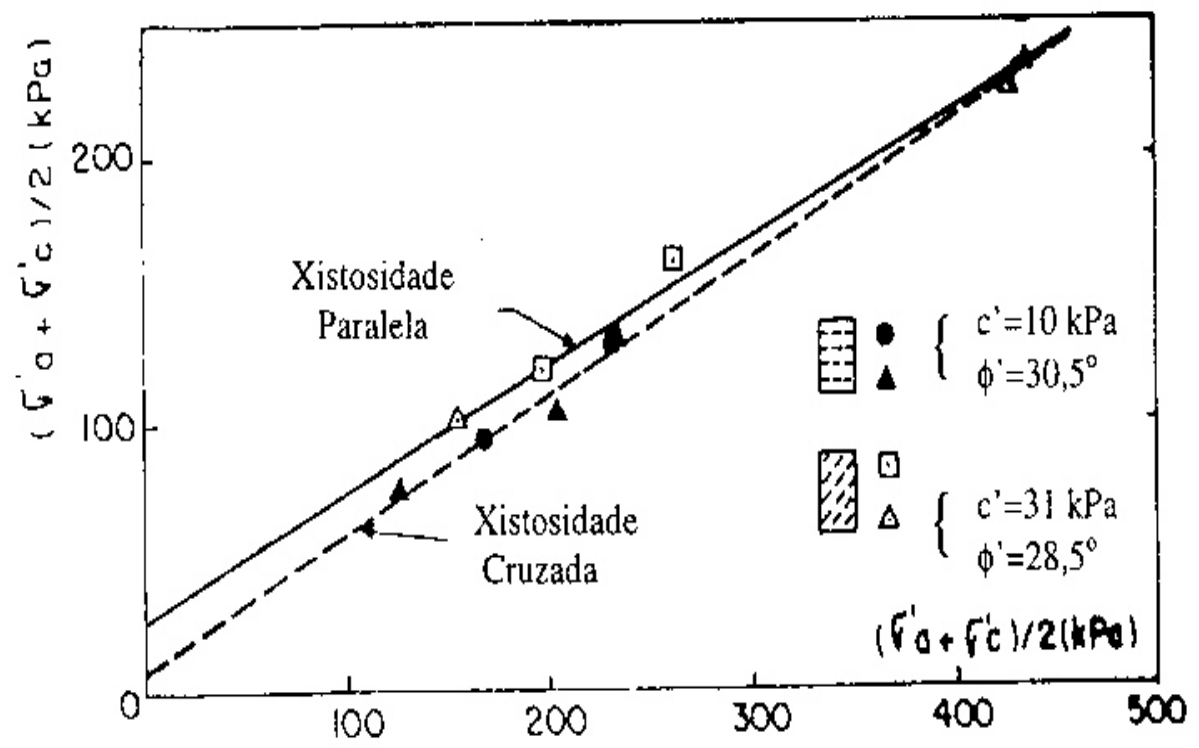

Figura 2.19 - Resultados dos ensaios triaxiais em amostras saturadas de solo gnáissico (Costa Filho \& De Campos, 1991). 


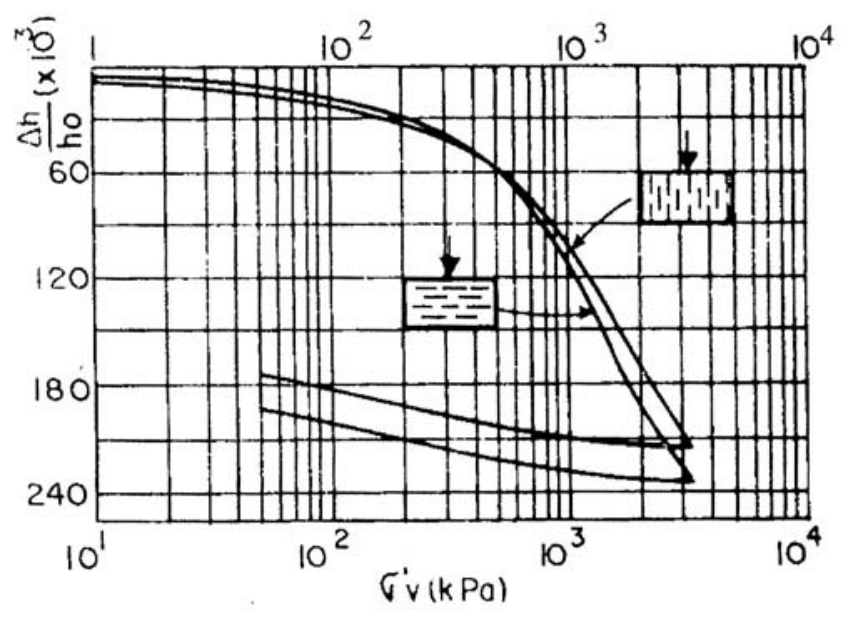

Figura 2.20 - Resultados dos ensaios oedométricos feitos em amostras submersas de solo gnáissico (Costa Filho \& De Campos, 1991).

Pode-se verificar, para os ensaios realizados que pequenas diferenças foram observadas para este solo. Os autores concluiram que, considerando o número limitado de ensaios realizados, os resultados obtidos sugeriram que a anisotropia estrutural não é fator dominante para solos saprolíticos de gnaisse em avançado estágio de intemperismo.

Maciel (1991) estudou a anisotropia de um solo residual jovem da região de Costa Brava, atravéz de ensaios de cisalhamento direto e triaxial. Para esse estudo foram coletados brocos indeformados em dois níveis do horizonte de solo residual jovem, um a 2 metros e outro a 3 metros de profundidade; os corpos de prova submetidos aos ensaios de cisalhamento direto foram moldados com o plano de ruptura coincidindo com a xistosidade do material e perpendicular a esta, e os corpos de prova utilizados nos ensaios triaxiais foram moldados in-situ, através da cravação de um molde de PVC com as dimensões da amostra.

De acordo com Maciel, os resultados não mostraram nenhum efeito de anisotropia no valor de resistência ao cisalhamento. Através do estudo da microfábrica destes materiais, observou-se que a micronível os grãos minerais já não se encontravam mais em contato ou os contatos entre eles já começavam a ser destruídos, com a presença de uma matriz ferro argilosa preenchendo o espaço entre os grãos e suas fraturas. Assim, o processo de intemperismo tende a micronível, a sobrepor uma eventual anisotropia estrutural, que poderia ser esperada, pela observação a macronível 
(xistosidades características), no valor da resistência ao cisalhamento. Além disto, apesar das partículas de solo saprolítico ainda apresentarem um certo alinhamento, típico da rocha matriz, observada em análise via microscópico ótico, notou-se que com o cisalhamento sua microfábrica original é totalmente destruída, anulando qualquer efeito de anisotropia.

Com relação aos ensaios triaxiais feitos por Maciel, observou-se que no nível inferior $(\mathrm{Z}=3 \mathrm{~m}$ ) de solo saprolítico, as amostras de $100 \mathrm{~mm}$ horizontais romperam a menores deformações (4,8 e 6,7 \%) que as verticais (15,3 e 12,7 \%).

Maciel conclui que quanto a resistência o solo teve um comportamento praticamente isotrópico e que quanto a deformabilidade o solo teve um comportamento anisotrópico.

Deve-se ressaltar que os ensaios reportados por Maccarini (1980), Costa Filho et al (1989) e Maciel (1991) apresentam limitações quanto ao estudo da anisotropia do solo. O equipamento de cisalhamento direto, utilizado por estes autores, não possibilita o controle da magnitude e da direção das tensões principais. O equipamento triaxial utilizado por Costa Filho et al e Maciel, também apresenta uma importante limitação de impor tensões principais idênticas no plano horizontal. Sendo assim, o equipamento triaxial cúbico é mais adequado para estudos de anisotropia de solos, uma vez que permite o controle independente da magnitude das três tensões principais, e em particular da tensão intermediária $\left(\sigma_{2}\right)$.

Reis (1998) apresentou um estudo sobre o comportamento de um solo residual maduro de gnaisse, da região de Viçosa, Minas Gerais. Para realização do estudo, foi construído um equipamento triaxial cúbico. O programa de ensaios constou de ensaios triaxiais convencionais, com carregamento do corpo de prova em três direções ortogonais diferentes (direções x, y e z), com tensões de confinamento iguais a 50, 100, 150, e $200 \mathrm{kPa}$; sendo também realizado um ensaio de compressão hidrostática. Para isso as amostras foram moldadas nas direções perpendicular (direção z) e paralela (direção y e x) à inclinação das foliações apresentadas pelo solo. Os ensaios de Reis (1998) e Reis \& Azevedo (1998) foram feitos com amostras não saturadas. Para minimizar os efeitos da sucção procurou-se ensaiar corpos de prova com teores de umidade semelhantes. Os resultados foram analisados em termos de resistência e deformabilidade. A Figura 2.21 mostra o gráfico p x q dos resultados obtidos para as três direções, bem como resultados de ensaios triaxiais do tipo CD realizados, em um aparelho triaxial convencional, nos quais não se controlou a direção segundo a qual 
cisalhava-se a amostra. Deste gráfico pode-se concluir que quanto a resistência o solo apresentou um comportamento praticamente isotrópico definido por uma coesão igual a $78,9 \mathrm{kPa}$ e angulo de atrito igual a 29,6 $6^{0}$ A tabela 2.5 apresenta os módulos de deformabilidade encontrados para 20\%, 50\% e 90\% da ruptura nas três direções analisadas para ensaios de 50 e $200 \mathrm{kPa}$ de confinamento. Quanto a deformabilidade pode-se inferir que o solo analisado apresenta um comportamento anisotrópico.

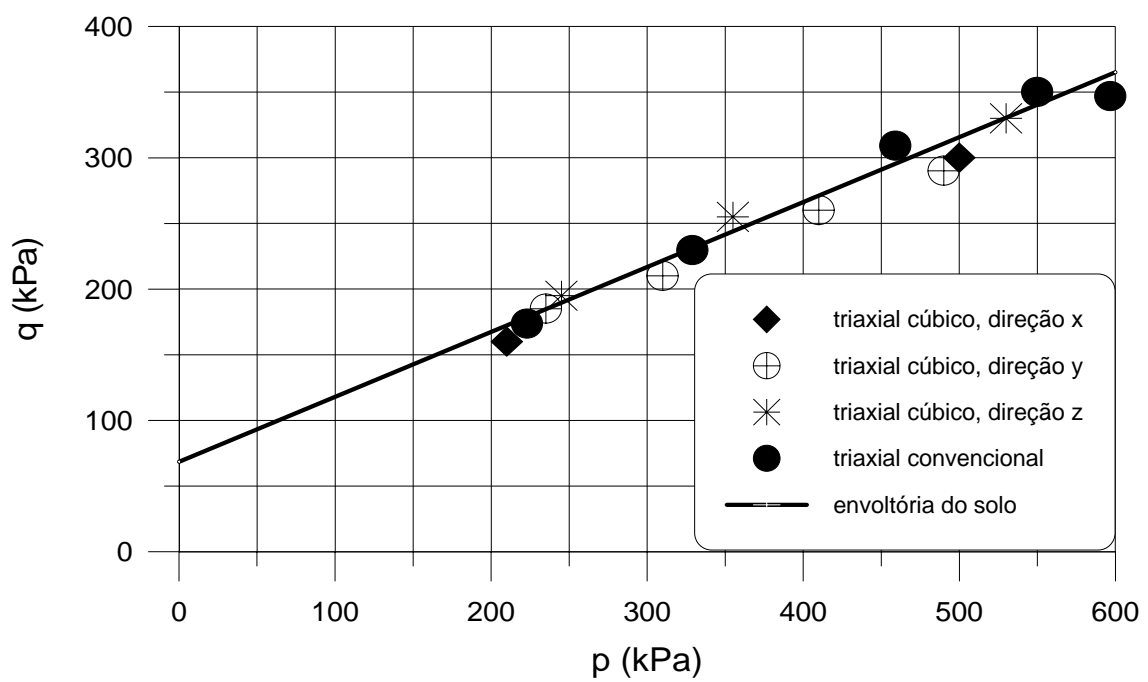

Figura 2.21 - Gráfico p x q, na ruptura, dos ensaios realizados (Reis \& Azevedo, 1998).

Tabela 2.5 - Valores de módulo de Young para carregamento nas direções x, y, e z (Reis \& Azevedo, 1998).

\begin{tabular}{|c|c|c|c|c|c|c|c|c|c|}
\hline \multirow[t]{2}{*}{$\begin{array}{l}\text { Tensão } \\
(\mathrm{kPa})\end{array}$} & \multicolumn{3}{|c|}{$\begin{array}{l}\mathrm{E}_{20} \\
(\mathrm{MPa})\end{array}$} & \multicolumn{3}{|c|}{$\begin{array}{l}\mathrm{E}_{50} \\
(\mathrm{MPa})\end{array}$} & \multicolumn{3}{|c|}{$\begin{array}{l}\mathrm{E}_{90} \\
(\mathrm{MPa})\end{array}$} \\
\hline & $\mathrm{x}$ & $\mathrm{y}$ & $\mathrm{z}$ & $\mathrm{x}$ & $\mathrm{y}$ & $\mathrm{z}$ & $\mathrm{x}$ & $\mathrm{y}$ & $\mathrm{z}$ \\
\hline 50 & 19,4 & 37 & 52 & 16,8 & 20,5 & 48,8 & 11,3 & 11,5 & 21,9 \\
\hline 200 & 24,5 & 23,2 & 33,0 & 17,1 & 16,1 & 29,7 & 7,7 & 9,49 & 13,5 \\
\hline
\end{tabular}

Reis \& Azevedo (1999) realizaram um estudo semelhante ao de Reis (1998) e Reis \& Azevedo (1998) em um solo residual jovem de gnaisse, no qual os bandamentos herdados da rocha matriz não eram tão marcantes, em condições saturadas. As amostras foram ensaiadas na direção Z “perpendicular à foliação”, direção y “paralela à foliação” 
e direção vertical “em relação à apresentada pela foliação no campo”. Foi feito também um ensaio de compressão hidrostática. Neste trabalho observou-se que o solo, mesmo em condições saturadas, quanto à resistência mostrou um comportamento isotrópico e quanto a deformabilidade apresentou comportamento anisotrópico.

Aleixo (1998) em seu estudo utilizou o equipamento triaxial cúbico desenvolvido na PUC-RIO. O programa experimental constou de ensaios de compressão axial e hidrostática, sob condições drenadas de carregamento. Os corpos de prova foram moldados a partir de blocos indeformados de solos residuais jovem e maduro, paralelos e perpendiculares à estratificação observada no solo. Foram ensaiados também corpos de prova compactados destes mesmos materiais. A análise dos resultados permitiu a verificação dos efeitos da direção de carregamento dos corpos de prova, do nível das tensões de confinamento, do grau de intemperismo, do arranjo estrutural dos grãos e dos efeitos do grau de saturação. Neste ítem só será detalhado os efeitos da direção de carregamento (anisotropia). Os efeitos restantes serão detalhados no ítem referente a trabalhos que tiveram como objetivo a investigação, do ponto de vista de resistência e deformabilidade, de um perfil de solo residual (solo residual jovem e solo residual maduro). Quanto ao efeito da direção de carregamento (anisotropia), a resistência em ambas as direções se mostraram semelhantes, sendo cerca de 10 \% maior na direção ortogonal à estratificação; e quanto a deformabilidade, o solo carregado na direção ortogonal apresentou, em média, uma rigidez de 30 \% maior que na direção paralela à estratificação. Em relação à verificação da anisotropia inerente ou estrutural, pode-se concluir que o solo apresentou menores deformabilidades na direção $\mathrm{z}$ (ortogonal à estratificação) que nas outras duas direções, ficando mais evidenciada no solo jovem indeformado um comportamento anisotrópico. Já para o solo maduro indeformado, as deformações nas três direções foram praticamente iguais, se comportando como um material isotrópico. Para os solos jovem e maduro compactados, a anisotropia ficou mais evidenciada. A Tabela 2.6 apresenta os resultados dos parâmetros de resistência obtidos por este autor para amostras de solo residual maduro e solo residual jovem ambas saturados ou parcialmente saturadas tanto indeformadas como compactadas. 
TABELA 2.6 - Resultados de ensaios triaxiais do tipo convencional realizados no triaxial cúbico (Aleixo, 1998).

\begin{tabular}{|c|c|c|c|c|c|}
\hline $\begin{array}{l}\text { SOLORESIDUAI } \\
\text { (GNASSE) }\end{array}$ & $\begin{array}{l}\text { CONDIÇÃODE } \\
\text { ENSAIO }\end{array}$ & $\begin{array}{l}\text { DIREÇÃODECISALHAMENIO } \\
\text { EMRELAÇÃOÀS XISTOSIDADES }\end{array}$ & $\begin{array}{c}\text { ESTADODA } \\
\text { AMOSIRA }\end{array}$ & $\begin{array}{c}\text { COESÃO } \\
(\mathrm{kPa})\end{array}$ & \begin{tabular}{|c|} 
ÂNGULODE \\
ATRTO(GRAUS)
\end{tabular} \\
\hline $\begin{array}{l}\text { MADURO } \\
\text { MADURO }\end{array}$ & $\begin{array}{l}\text { SATURADO } \\
\text { SATURADO }\end{array}$ & $\begin{array}{l}\text { ORTOGONAL } \\
\text { PARALELO }\end{array}$ & $\begin{array}{l}\text { INDEFORMADA } \\
\text { INDEFORMADA }\end{array}$ & $\begin{array}{l}71,1 \\
68,1\end{array}$ & $\begin{array}{c}16 \\
16,1\end{array}$ \\
\hline $\begin{array}{l}\text { JOVEM } \\
\text { JOVEM }\end{array}$ & $\begin{array}{l}\text { SATURADO } \\
\text { SATURADO }\end{array}$ & $\begin{array}{l}\text { ORIOGONAL } \\
\text { PARALELO }\end{array}$ & $\begin{array}{l}\text { INDEFORMADA } \\
\text { INDEFORMADA }\end{array}$ & $\begin{array}{l}45,1 \\
43,8\end{array}$ & $\begin{array}{l}12,3 \\
12,1\end{array}$ \\
\hline $\begin{array}{l}\text { MADURO } \\
\text { MADURO }\end{array}$ & $\begin{array}{l}\text { PARC SATURADO } \\
\text { PARC SATURADO }\end{array}$ & $\begin{array}{l}\text { ORTOGONAL } \\
\text { PARALELO }\end{array}$ & $\begin{array}{l}\text { INDEFORMADA } \\
\text { INDEFORMADA }\end{array}$ & $\begin{array}{l}127,2 \\
122,3\end{array}$ & $\begin{array}{l}20,4 \\
20,6\end{array}$ \\
\hline $\begin{array}{l}\text { JOVEM } \\
\text { JOVEM }\end{array}$ & $\begin{array}{l}\text { PARC SATURADO } \\
\text { PARC SATURADO }\end{array}$ & $\begin{array}{l}\text { ORIOGONAL } \\
\text { PARALELO }\end{array}$ & $\begin{array}{l}\text { INDEFORMADA } \\
\text { INDEFORMADA }\end{array}$ & $\begin{array}{l}64,4 \\
60,7\end{array}$ & $\begin{array}{l}19,6 \\
19,8\end{array}$ \\
\hline $\begin{array}{l}\text { MADURO } \\
\text { MADURO }\end{array}$ & $\begin{array}{l}\text { SATURADO } \\
\text { SATURADO }\end{array}$ & $\begin{array}{l}\text { ORTOGONAL } \\
\text { PARALELO }\end{array}$ & $\begin{array}{l}\text { COMPACTADA } \\
\text { COMPACTADA }\end{array}$ & $\begin{array}{l}55,3 \\
45,8\end{array}$ & $\begin{array}{l}8,1 \\
9,3\end{array}$ \\
\hline $\begin{array}{l}\text { JOVEM } \\
\text { JOVEM }\end{array}$ & $\begin{array}{l}\text { SATURADO } \\
\text { SATURADO }\end{array}$ & $\begin{array}{l}\text { ORIOGONAL } \\
\text { PARALELO }\end{array}$ & $\begin{array}{l}\text { COMPACTADA } \\
\text { COMPACTADA }\end{array}$ & $\begin{array}{c}64 \\
54,4\end{array}$ & $\begin{array}{l}9,6 \\
10,7\end{array}$ \\
\hline
\end{tabular}

\subsection{4 - Condição não Saturada}

Para atender a situações de campo em que o solo não se encontra saturado, nas últimas décadas foram realizados vários trabalhos, tendo como objetivo obter compreensão e caracterização melhores dos comportamentos mecânico e hidráulico desses solos.

Este item tem como objetivo abordar, de maneira bem simplificada, aspectos importantes desses solos, tendo-se em vista que o solo residual normalmente é encontrado em condições parcial mente saturadas. Em primeiro lugar será apresentado o conceito de sucção e curva característica; em segundo, serão abordadas as características de tensão versus deformação, comentando-se os efeitos da sucção tanto em ensaios de cisalhamento como em ensaios de adensamento; e, em terceiro lugar, será feito comentário a respeito da resistência ao cisalhamento desses solos, quando será apresentada a formulação proposta por Fredlund et al. (1978) e discutido o comportamento dos parâmetros envolvidos na referida formulação, no tocante à resistência, através de resultados de ensaios de laboratório realizados por diversos autores em solos não-saturados. 


\subsubsection{Potencial de água no solo.}

\subsection{Introdução}

Em se tratando de solos não saturados, a maneira como a água se distribui em seus vazios, sua composição, seu estado energético ou seu potencial em relação a um estado padrão de referência desempenha papel fundamental no entendimento do comportamento que estes venham a apresentar. De fato, os solos não saturados apresentam características de deformabilidade, resistência e permeabilidade que variam grandemente a depender do valor de sucção, que como veremos adiante nada mais é do que uma medida de potencial da água no solo.

\subsection{Conceituação geral}

O estado de energia da água do solo é a soma de duas formas de energia: cinética e potencial. Como os movimentos migratórios da água no interior do solo são de velocidades muito baixas, a quantificação da energia cinética perde sua importância diante da energia pontencial; portanto, a energia potencial pode caracterizar o estado de energia da água do solo (Baver et al. 1972).

Quando um trabalho é realizado sobre a água, sob condições específicas, sua energia potencial é alterada em uma quantidade igual ao trabalho realizado. A variação da energia potencial da água em consideração, em relação a um estado padrão de referência arbitrado, é chamado de Potencial da Água do Solo (Marshall \& Holmes, 1981).

A água no estado padrão, Ponto A (Figura 2.22), encontra-se, em condições normais de temperatura e pressão externa (pressão atmosférica), com a interface líquido-gás plana, livre de sais minerais ou outros solutos e está situado em um referencial de posição definido (Figura 2.22).

O Potencial Total da Água do Solo ( $\psi$ ), Figura 2.22, representa o trabalho útil que deve ser realizado em uma quantidade infinitesimal de água pura, para conduzi-la, reversível e isotermicamente, desde um reservatório sob condições padronizadas (isto é água pura, em uma determinada cota e sujeita à pressão atmosférica) - Ponto A - até a água no solo, na cota de interesse (Ponto B). 
TRANSPORTE REVERSIVEL E ISOTÉRMICO

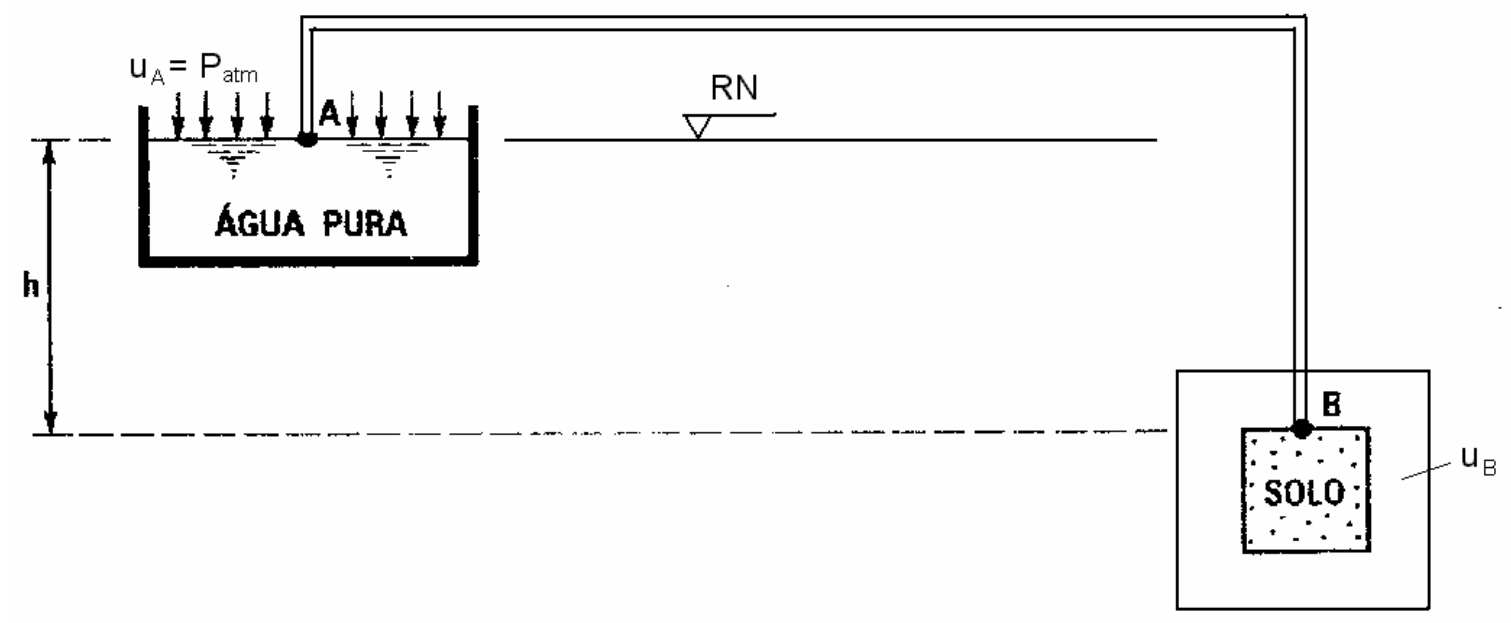

Figura 2.22 - Esquema ilustrativo da definição de potencial total da água no solo.

Os componentes do potencial total da água no solo são o potencial osmótico, o potencial matricial, o potencial gravitacional, e o potencial pneumático. Outros componentes podem ser incluídos, como, o potencial de consolidação ou o potencial térmico, porém serão descartados por terem importância menor no comportamento geotécnico de solos não saturados.

O Potencial Gravitacional $\left(\psi_{\mathrm{g}}\right)$ traduz a componente de posição, isto é, o fato de que a água no solo esteja em cota diferente da água do reservatório padrão (h \# 0). Ele equivale ao potencial total $(\psi)$ atrás definido, quando a água do solo é idêntica à água do reservatório padrão (água pura ou solução com a mesma composição da água do solo), está à mesma pressão $\left(\mathrm{u}_{\mathrm{B}}=\right.$ patm) e o solo se encontra saturado (não existem efeitos decorrentes da matriz do solo).

O Potencial osmótico ou de Soluto ( $\psi$ os $)$ reflete a influência da presença de solutos na água do solo. Ele equivale ao Potencial Total, quando tanto a água pura do reservatório padrão quanto a solução de água do solo encontram-se à mesma cota $(\mathrm{h}=0)$, à mesma pressão $\left(\mathrm{u}_{\mathrm{B}}=\right.$ patm) e não ocorrem efeitos da matriz do solo (solo saturado)

O Potencial pneumático ( $\left.\psi_{\mathrm{pn}}\right)$ origina-se de pressões externas de gás diferentes da pressão atmosférica e tem especial importância quando se consideram os ensaios de placa de pressão ou a técnica de translação de eixos. Ele é equivalente ao potencial total desde que a água do solo seja idêntica à água do reservatório padrão, esteja à mesma 
cota $(\mathrm{h}=0)$ que o reservatório padrão, porém sujeita à pressão diferente da atmosférica ( $\mathrm{u}_{\mathrm{B}}$ \# patm) e que o solo esteja saturado.

O Potencial matricial $\left(\psi_{\mathrm{m}}\right)$ da água do solo é um potencial de pressão e resulta do efeito combinado da ação de forças capilares e de adsorção, que surgem devido à interação entre a água e as partículas minerais (matriz) que compõem o solo (Hillel, 1971e Baver et al., 1972). A Figura 2.23 apresenta os dois mecanismos de interação solo-água.

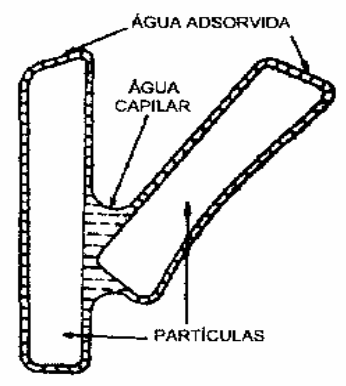

Figura 2.23 - Água de um solo não saturado sujeita à capilaridade e adsorção, que combinados produzem um potencial matricial (Hillel, 1971).

Ele equivale ao potencial total quando a água do solo é idêntica à água do reservatório padrão (água pura ou solução com a mesma composição da água do solo), está a mesma cota $(\mathrm{h}=0)$ e sob a mesma pressão $\left(\mathrm{u}_{\mathrm{B}}=\right.$ patm) que o reservatório padrão. Para se tirar a água do solo retida por estas forças capilares e de adsorção, é preciso fornecer energia ao sistema. Dessa forma, o potencial matricial é negativo; pois, há necessidade de se realizar trabalho sobre o sistema, para levar a água do solo do seu estado original ao estado padrão.

\subsection{Potencial da água dos solos não saturados}

Considerando que os processos que ocorrem no interior de uma massa de solo, não sujeita a variações de volume decorrentes de adensamentos, são isotérmicos, o potencial da água do solo saturado pode ser expresso como:

$$
\psi=\psi_{\mathrm{p}}+\psi_{\mathrm{o}}+\psi_{\mathrm{z}} \text {, onde } \psi_{\mathrm{p}} \text { é o potencial de pressão, decorrente, por }
$$
exemplo, da submersão do solo. 
No caso de se considerar uma massa de solo não saturado, nas mesmas condições anteriores, passa a ser representada pelo potencial matricial e neste caso o potencial total da água será: $\psi=\psi_{\mathrm{M}}+\psi_{\mathrm{o}}+\psi_{\mathrm{z}}$.

A interação solo-água pode também ser quantificada a partir da afinidade que um solo não saturado tem por água. Se colocado em contacto com um reservatório de água o solo absorve água, isto é, ele exerce uma sucção sobre a água. Se uma pressão de sucção é aplicada sobre o reservatório de água livre, quando o fluxo cessar tem-se uma pressão na água livre equivalente à pressão na água do solo, o que se constitui numa medida de sucção do solo.

A sucção total do solo (S) é definida como a pressão manométrica negativa, em relação à pressão externa de gás sobre a água do solo, que deve ser aplicada a um reservatório de água pura (à mesma cota e temperatura) de sorte a que se mantenha o equilíbrio, através de uma membrana semi-permeável (permite o fluxo de água, porém não o de solutos), entre a água do reservatório e a água do solo. A Figura 2.24 esquematiza essa definição.

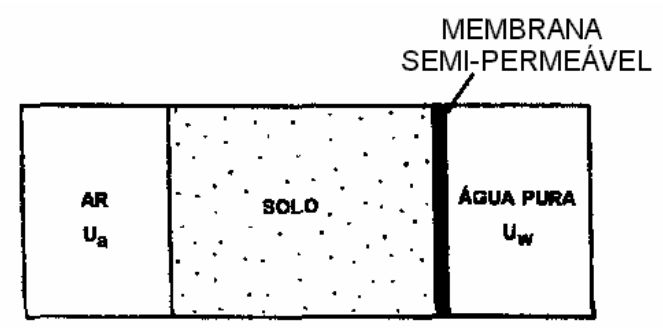

Figura 2.24 - Esquema ilustrativo da definição de sucção: Corresponde a $\mathrm{u}_{\mathrm{a}}-\mathrm{u}_{\mathrm{w}}$ de sorte a não haver fluxo através da membrana semi-permeável. Comumente $\mathrm{u}_{\mathrm{a}}=$ Patm.

Deve-se notar que a sucção total corresponde ao potencial total, quando os potenciais gravitacional e pneumático podem ser desprezados. Dessa forma, a sucção total pode ser separada em suas duas componentes, a sucção osmótica e a sucção matricial, que correspondem, respectivamente, ao potencial osmótico e ao potencial matricial.

A sucção osmótica equivale à sucção total quando o solo se encontra saturado, ou seja, quando a componente matricial não ocorre, restando apenas o efeito da concentração de solutos.

Em contrapartida, a sucção matricial, equivale à sucção total quando a água do solo é idêntica à água padrão (água pura ou solução com a mesma composição da água do solo), restando apenas o efeito da matriz do solo (capilaridade e adsorção). 
A Figura 2.25 ilustra os conceitos de sucção matricial, osmótica e total.

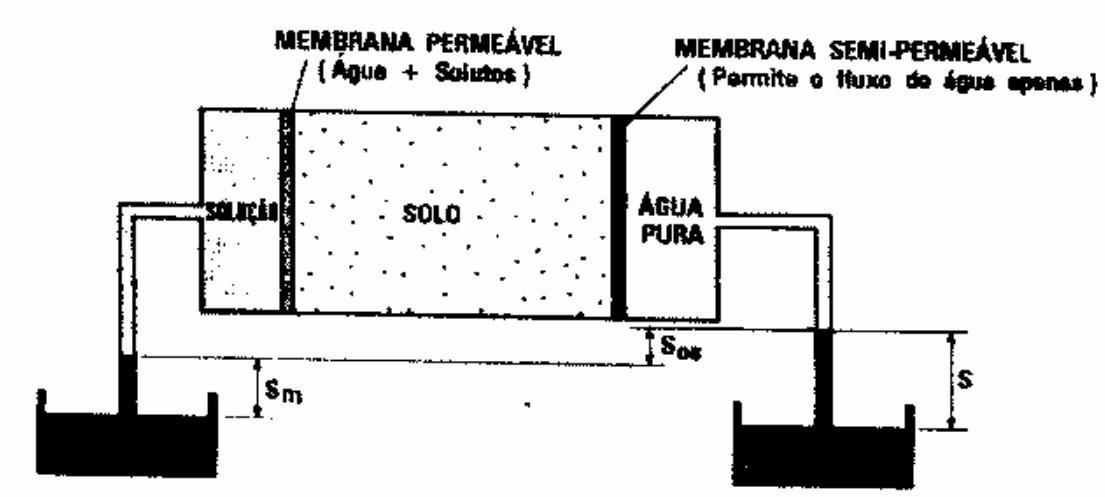

Figura 2.25 - Representação dos conceitos de sucção matricial, osmótica e total.

Pode-se escrever então que: $\mathrm{S}=\mathrm{S}_{\mathrm{m}}+\mathrm{S}_{\mathrm{os}}=\left(\mathrm{u}_{\mathrm{a}}-\mathrm{u}_{\mathrm{w}}\right)+\mathrm{S}_{\mathrm{os}}$.

Atualmente, existem duas correntes básicas a respeito dos fatores que governam o comportamento dos solos não saturados. Autores como Fredlund (1979), Edil \& Motan (1984), e Alonso et alli (1987) assumem que o comportamento dos solos não saturados é regido apenas pela sucção matricial. Por outro lado, Richards et al. (1986), discordam da afirmação anterior, adimitindo que este comportamento é governado pela sucção total entendida como o somatório da sucção matricial e da sucção osmótica.

Segundo Teixeira \& Vilar (1997), a sucção matricial precisa ser conhecida ou controlada, pois desempenha papel fundamental no comportamento do solo, visto que a deformabilidade e a resistência ao cisalhamento variam diretamente com a sucção. Contribuem para a sucção matricial os efeitos das forças capilares e de adsorção, de difícil separação na prática, obrigando que, na maioria dos trabalhos, sejam feitas abordagens considerando a influência global da sucção matricial no comportamento dos solos. O que se constata é que em Mecânica dos solos, tem-se, rotineiramente atribuído uma mudança na sucção total à variações na sucção matricial (sucção osmótica despresível), de modo que: $\mathrm{Sm}=\mathrm{u}_{\mathrm{a}}-\mathrm{u}_{\mathrm{w}}$. 


\subsubsection{2 - Curva de Retenção da Água do Solo}

A curva característica define a relação entre o teor de umidade em um solo e a correspondente sucção matricial. A curva característica é histerética em relação às condições de umedecimento e secagem impostas ao material, sendo usual considerar somente a curva de secagem (Fredlund et al., 1994). Na Figura 2.26, apresenta-se uma curva de secagem e umedecimento típica para um solo siltoso. Nesta figura, o valor de entrada de ar corresponde à sucção na qual o ar começa a entrar no solo, iniciando-se a dessaturação; o conteúdo residual de água corresponde ao conteúdo de água a partir do qual grande aumento de sucção é requerido para remover quantidade adicional de água do solo.

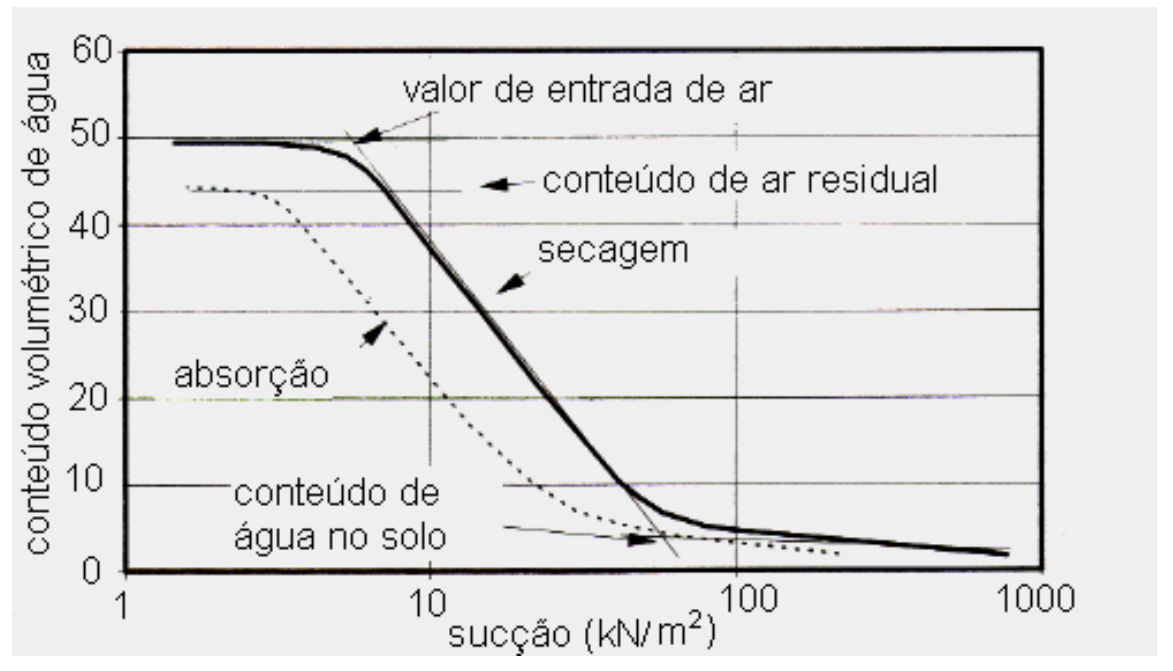

Figura 2.26 - Curva característica (Fredlund et al., 1994).

A relação entre o potencial matricial e o teor de umidade ou grau de saturação não é unívoca, dependendo da história de variação do teor de umidade, Figura 2.26. Sua determinação é feita em laboratório segundo os seguintes procedimentos:

- por secagem (desidratação, dessorção), quando uma amostra previamente saturada é exposta a potenciais matriciais gradualmente maiores, com sucessivas medidas destes valores versus o teor de umidade de equilíbrio de cada estágio; e 
- $\quad$ por molhamento (hidratação, adsorção), quando uma amostra seca ao ar tem seu ptencial matricial reduzido gradualmente, com sucessivas medidas do potencial versus o teor de umidade de equiíbrio em cada estágio.

Segundo Rohm (1992), os principais fatores que interferem na forma da curva característica dos solos são a distribuição granulométrica, a distribuição dos poros, a estrutura e a mineralogia das partículas.

Nos solos arenosos, devido ao fato dos poros serem relativamente grandes, a uma dada sucção muitos poros se esvaziam e poucos poros ainda pode reter água. Nos solos argilosos, devido ao fato da distribuição dos poros ser melhor, a cada sucção matricial apenas uma parcela dos poros drenam, permanecendo ainda uma certa quantidade cheia de água.

A estrutura também afeta a forma da curva característica. Este fato pode ser verificado, por exemplo, através da comparação da curva característica de um mesmo solo agregado em suas condições naturais e compactada (Hillel, 1971). Este autor, obsevou que a compactação conseguiu diminuir as dimensões dos grandes poros entre os agregados; contudo, os microporos internos aos agregados permaneceram inalterados.

Quanto ao fenômeno de histerese da curva característica, segundo Hillel (1971), ele pode ser atribuído a diversas causas:

- a desuniformidade geométrica de cada poro (que são em geral vazios de formas irregulares interconectados por passagem menores) gerando o efeito ink bottle;

- $\quad$ ao ângulo de contato, que é maior quando ocorre umedecimento do solo e menor na fase de secagem, gerando raios de curvatura diferentes em uma ou em outra situação, tal fato decorre da existência de impurezas adsorvidas às superfícies secas das partículas tornando-as mais ásperas;

- bolhas de ar capturadas nos vazios do solo durante a fase de umedecimento; 
- e alteração na estrutura do solo, decorrentes da expansão ou contração, associadas a ciclos de umidecimento ou secagem do solo.

\subsubsection{Características de tensão versus deformação}

Um número crescente de trabalhos tem sido desenvolvido com o objetivo de estudar a influência da sucção no comportamento dos solos. Neste item será discutido, de maneira bem simplificada, o efeito da sucção tanto no cisalhamento como no adensamento. Trabalhos deste tipo foram bastante desenvolvidos na Universidade da Cataluyna (Josa et al., 1987).

\subsection{Cisalhamento}

A influência da sucção no cisalhamento de solos não-saturados pode ser observada através da curva tensão versus deformação. Para isso, basta a realização de ensaios com o mesmo confinamento e com valores de sucção diferentes, mas invariáveis em cada ensaio. Na Figura 2.27, tenta-se mostrar a influência da sucção no cisalhamento, através de um esquema com três ensaios hipotéticos; o confinamento é o mesmo para os três ensaios, por exemplo $\left(\sigma_{3}=100 \mathrm{kPa}\right)$, e a sucção, diferente. Supondo a sucção para o primeiro ensaio igual a $S_{1}$, a sucção para o segundo ensaio igual a $S_{2}$ e a sucção para o terceiro ensaio igual a $S_{3}$, em que $S_{3}$ é maior que $S_{2}$ e $S_{2}$ é maior que $S_{1}$, o que se verifica é que, quanto maior a sucção, maiores serão a rigidez e a tensão necessárias para romper o solo; tal comportamento foi observado por diversos pesquisadores (Josa et al., 1987).

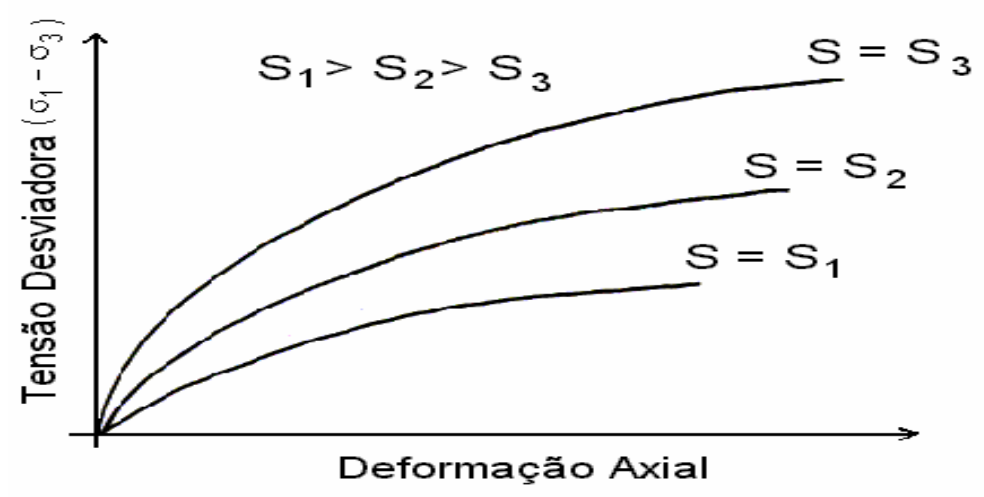

Figura 2.27 - Curva ilustrando a tensão versus deformação em função da sucção. 


\subsection{Adensamento}

A influência da sucção no adensamento de solos não-saturados pode ser avaliada através de um gráfico de tensão aplicada versus índices de vazios. Para isso, basta a realização de ensaios de adensamento, em que a sucção seja diferente para cada ensaio, mas invariável durante cada ensaio. Na Figura 2.28, mostra-se, de maneira hipotética, como a sucção tem influência no adensamento. Nessa figura, também se apresenta um esquema de três ensaios, em que se supõem a sucção igual a $S_{1}$ para o primeiro ensaio, igual a $S_{2}$ para o segundo ensaio e igual a $S_{3}$ para o terceiro ensaio, sendo $S_{1}<S_{2}<S_{3}$. Diante disso, o que se verificou foi que, quanto maior a sucção do solo, menor a variação do índice de vazios durante o ensaio. Isso pode ser explicado pelo fato de que, quanto maior a sucção do solo, mais rígido ele se torna, tendo, assim, menor variação no índice de vazios durante o ensaio.

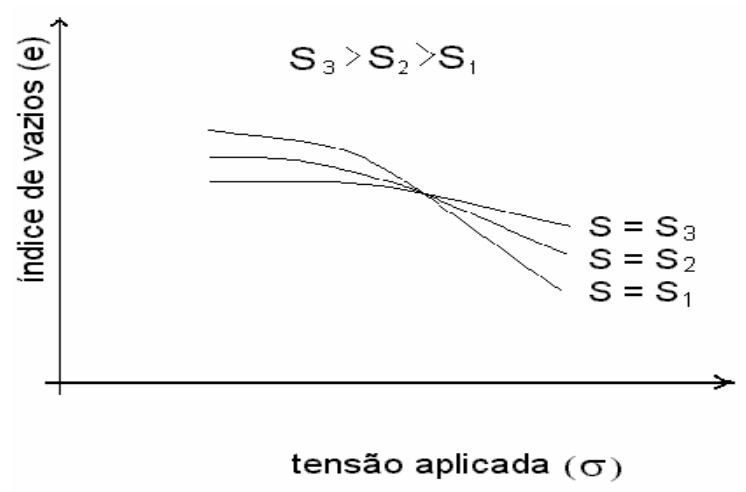

Figura 2.28 - Gráfico ilustrando o comportamento índice de vazios versus tensão aplicada em função da sucção.

Ainda no que diz respeito à variação de volume, fato interessante que ocorre é que, quando se tenta aplicar o princípio da tensão efetiva em solos não-saturados, é verificado que sua validade é questionável. Sabe-se que em solos saturados esse princípio teve grande sucesso, e vários trabalhos o comprovaram. Em solos nãosaturados, Bishop (1959) propôs a seguinte equação:

$\sigma^{\prime}=\sigma-u_{a}+\chi\left(u_{a}-u_{w}\right)$

em que $\sigma$ ' é a tensão efetiva, $\sigma$ a tensão total, $u_{\mathrm{a}}$ a pressão do ar e $\mathrm{u}_{\mathrm{w}}$ a pressão de água, sendo $\chi$ um parâmetro que depende do grau de saturação e varia de zero para solo seco 
e a unidade para solo saturado. Nos ensaios de adensamento, à medida que se aumenta a tensão efetiva em solos saturados, observa-se diminuição de volume e, à medida que diminui a tensão efetiva, verifica-se aumento de volume. Segundo Gens (1995), em solos não saturados (Figura 2.29) alguns pesquisadores têm observado que durante o adensamento, se o corpo de prova for saturado, o solo pode apresentar dois comportamentos distintos: inchamento (aumento de volume) e colapso (diminuição de volume).

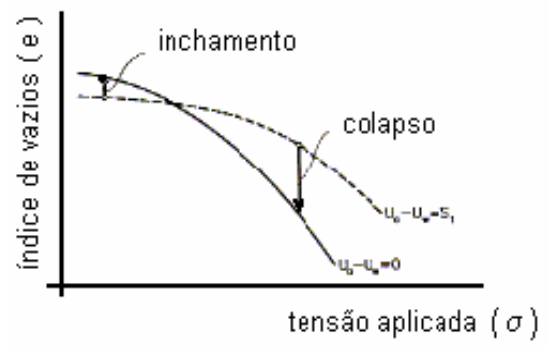

Figura 2.29 - Comportamento do solo não-saturado, mostrando inchamento e colapso (Gens, 1995).

O comportamento de inchamento pode ser explicado pela equação de Bishop (1959), pois a diminuição na sucção provocada pela saturação causa redução na tensão efetiva, implicando, assim, aumento do índice de vazios e, conseqüentemente, aumento de volume. O comportamento de colapso, entretanto, não é explicado pela equação de Bishop (1959), pois diminuição da sucção implicaria redução da tensão efetiva, que por sua vez causaria ao solo aumento do índice de vazios e não diminuição. Devido ao comportamento comentado anteriormente, em estudos com solos não-saturados verificase que o princípio de tensão efetiva não é bem aceito e que as avaliações precisam ser realizadas através da tensão total aplicada e da sucção (variáveis de estado).

\subsubsection{3 - Análise de Solos Não Saturados com base nas Variáveis de Estado}

As várias equações desenvolvidas, visando prever o comportamento do solo não saturado, apresentam em comum parâmetros característicos do comportamento do solo na descrição do estado de tensões. Isto tranforma a equação em uma relação constitutiva do comportamento do solo. Contudo, segundo Fredlund \& Morgenstern (1977), tem sido praticamente impossível obter a unicidade desse parâmetro, sendo ele muito dependente da trajetória de tensões adotado, o que dificulta muito sua aplicação prática. 
Coleman (1962) sugeriu o uso de variáveis de tensão reduzidas $\left(\sigma_{1}-\mathrm{u}_{\mathrm{a}}\right),\left(\sigma_{3}-\mathrm{u}_{\mathrm{a}}\right)$, e $\left(\mathrm{u}_{\mathrm{a}}-\mathrm{u}_{\mathrm{w}}\right)$ para representar as pressões axiais, confinantes e neutras, respectivamente, em um ensaio triaxial.

Matyas \& Radhakrishma (1968) introduziram o conceito de "parâmetro de estado” na descrição do comportamento volumétrico de solos não saturados. A variação de volume foi apresentada através de uma superfície tridimensional em função dos parâmetros $\left(\sigma-\mathrm{u}_{\mathrm{a}}\right)$, e $\left(\mathrm{u}_{\mathrm{a}}-\mathrm{u}_{\mathrm{w}}\right)$. Conforme os resultados apresentados pelos autores, tal superfície representativa da variação volumétrica é única desde que o solo parta de um mesmo estado inicial e siga somente trajetórias de aumento ou de diminuição de saturação.

Fredlund \& Morgenstern (1977), extraíram, a partir do estado de tensões a que está submetido um elemento de solo não saturado (Figura 2.30) dois tensores de tensões independentes, mostrados na Figura 2.31, representantes do estado de tensões do solo. Segundo estes autores, o comportamento do solo poderia ser previsto empregando-se qualquer uma das três combinações:

$$
\begin{gathered}
-\left(\sigma-\mathrm{u}_{\mathrm{w}}\right) \text { e }\left(\sigma-\mathrm{u}_{\mathrm{a}}\right) \\
-\quad\left(\sigma-\mathrm{u}_{\mathrm{w}}\right) \text { e }\left(\mathrm{u}_{\mathrm{a}}-\mathrm{u}_{\mathrm{w}}\right) \\
-\quad\left(\sigma-\mathrm{u}_{\mathrm{a}}\right) \text { e }\left(\mathrm{u}_{\mathrm{a}}-\mathrm{u}_{\mathrm{w}}\right)
\end{gathered}
$$

Por ser a pressão de ar nos poros dos solos, quando estes se encontram no estado aberto, igual à pressão atmosférica a combinação (c) tem sido a mais usada no meio científico. 


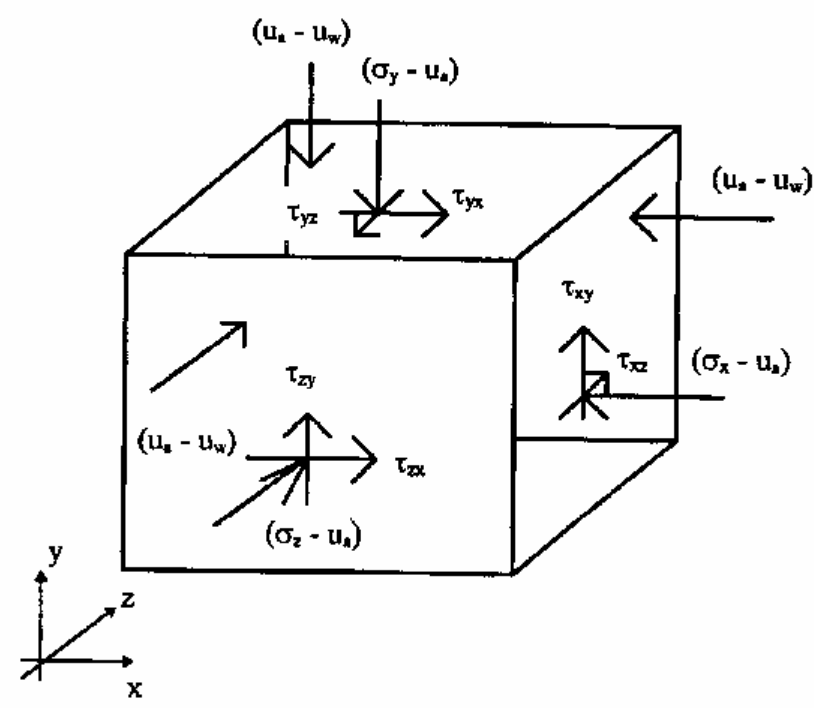

Figura 2.30 - Estado de tensões para as partículas sólidas e a membrana contrátil de um elemento de solo não saturado (Fredlund \& Morgenstern, 1977).

$$
\begin{aligned}
& {\left[\begin{array}{ccc}
\sigma_{x}-u_{a} & \tau_{y x} & \tau_{z x} \\
\tau_{z y} & \sigma_{y}-\text { ua } & \tau_{z y} \\
\tau_{x z} & \tau_{y z} & \sigma_{z}-u_{a}
\end{array}\right]} \\
& {\left[\begin{array}{ccc}
u_{a}-u_{w} & 0 & 0 \\
0 & u a-u_{w} & 0 \\
0 & 0 & u a-u_{w}
\end{array}\right]}
\end{aligned}
$$

Figura 2.31 - Tensores representantes do estado de tensões do solo (Fredlund \& Morgenstern, 1977).

A idéia de que estas duas variáveis de estado governam o comportamento dos solos não saturados foi aceita pela comunidade geotécnica. Dessa forma a mecânica dos solos não saturados passou a desenvolver formulações relacionadas a estas duas variáveis de estado, com o intuito de prever o comportamento desse tipo de solo. Entretanto Bloch (1978) criticou o estudo com base nas variáveis de estado, pois segundo este autor as hipóteses assumidas ignoram o potencial químico do solo. 


\subsubsection{4 - Resistência}

\subsubsection{1 - Introdução}

A resistência ao cisalhamento de um solo saturado é geralmente descrita utilizando-se o critério de resistência de Mohr-Coulomb e o conceito de tensões efetivas proposto por Terzaghi. A equação 2.2 apresentada abaixo ilustra o uso destas duas proposições:

$$
\tau=c^{\prime}+\left(\sigma-u_{w}\right) \operatorname{tg} \phi^{\prime}
$$

Onde $\tau$ é a tensão ao cisalhamento na ruptura; c' é a coesão efetiva do solo; $\sigma$ é a tensão normal total e $\phi$ 'é o ângulo de atrito interno do solo.

O estado tensional de um solo não saturado, de um ponto de vista microestrutural é resultado das diferentes solicitações às quais o solo é submetido, assim como da natureza e propriedades de suas fases componentes (fase sólida, fases líquida e gasosa e interações entre estas fases). A integração destes estados de tensão em cada ponto de uma determinada seção de solo não saturado irá resultar no estado de tensões do solo, compreendido ou medido de maneira externa à dada seção. Conforme pode-se notar, a resistência ao cisalhamento de um solo não saturado será dependente de uma série de fatores e interações, não podendo ser perfeitamente representada pela equação 2.2.

\subsubsection{2 - Resistência ao cisalhamento em solo não saturado}

Uma das primeiras e mais utilizadas expressões para relacionar a resistência ao cisalhamento com a sucção se deve a Bishop et al. (1960), equação 2.3, a qual utiliza o critério de ruptura de Mohr-Coulomb e a expressão proposta por Bishop (1959) para obtenção da tensão efetiva atuando em um solo não saturado.

$$
\tau=c^{\prime}+\left(\sigma-u_{a}+\chi\left(u_{a}-u_{w}\right)\right) \cdot \tan \phi^{\prime}
$$


Fredlund et al. (1978), utilizando as variáveis de estado, $\left(\sigma-\mathrm{u}_{\mathrm{a}}\right)$ e $\left(\mathrm{u}_{\mathrm{a}}-\mathrm{u}_{\mathrm{w}}\right)$, propuseram a seguinte expressão para resistência ao cisalhamento, equação 2.4 , que considera o efeito da sucção matricial sobre a resistência como sendo linear:

$\tau=\mathrm{C}+\left(\sigma-\mathrm{u}_{\mathrm{a}}\right) \operatorname{tg} \phi+\left(\mathrm{u}_{\mathrm{a}}-\mathrm{u}_{\mathrm{w}}\right) \operatorname{tg} \phi^{\mathrm{b}}$

em que c = intercepto de coesão; $\phi=$ ângulo de atrito interno, relativo às variações no termo $\left(\sigma-\mathrm{u}_{\mathrm{a}}\right)$ quando $\left(\mathrm{u}_{\mathrm{a}}-\mathrm{u}_{\mathrm{w}}\right)$ é constante; e $\phi^{\mathrm{b}}=$ ângulo de atrito interno, relativo às variações no termo $\left(\mathrm{u}_{\mathrm{a}}-\mathrm{u}_{\mathrm{w}}\right)$ quando $\left(\sigma-\mathrm{u}_{\mathrm{a}}\right)$ é mantido constante.

Algumas observações podem ser feitas da proposta de Fredlund et al., (1978):

a) o ângulo de atrito interno do solo é suposto constante com a sucção

b) a resistência ao cisalhamento cresce linearmente com a sucção.

c) Com este tratamento, passamos a ter uma envoltória de ruptura planar e não mais um linha, já que os círculos de Mohr agora são plotados em um diagrama tridimensional, com as variáveis de estado de tensão no plano horizontal e a resistência ao cisalhamento nas ordenadas.

d) Como o ângulo de atrito interno é suposto constante com a sucção, todo o ganho de resistência ao cisalhamento do solo se refletirá em um acréscimo de coesão, de modo que a coesão do solo não saturado pode ser quantificada como segue (equação 2.5):

$$
\mathrm{c}=\mathrm{c}^{\prime}+\left(\mathrm{u}_{\mathrm{a}}-\mathrm{u}_{\mathrm{w}}\right) \cdot \tan \phi^{b}
$$

A validade da equação 2.4 tem sido contudo contestada por diversos autores. Um aspecto chama atenção quando comparamos as equações (2.3 e 2.4): Desta comparação notamos que $\operatorname{tg} \phi^{b}=\chi \operatorname{tg} \phi^{\prime}$. Ora, se $\chi=1$ para os solos saturados, devese esperar que $\phi^{b}$ seja aproximadamente igual a $\phi$ 'quando o solo esteja no campo das baixas sucções e que $\phi^{\mathrm{b}}$ tenda para zero à medida em que a sucção aumente e o solo se distancie da sua condição de saturado. Esta observação foi feita por Wood (1979) segundo o qual a equação 2.4 considera que os acrécimos de coesão não são influenciados pela não saturação do solo. 
No que diz respeito à linearidade ou não da curva de resistência (q) versus sucção, Fredlund et al. (1987), Escario \& Sáez (1987), Abramento \& Carvalho (1989), Escario \& Juca (1989), Röhm \& Vilar (1994), Teixeira \& Vilar (1997) admitiram que tal curva se comporta de maneira não-linear, ou seja, a não validade da equação 2.4. Entretanto, Fredlund et al.(1978), Gullati \& Satija (1981), Ho \& Fredlund (1982), admitiram que tal curva se comporta de maneira linear, através de resultados de ensaios triaxiais com sucção controlada onde o uso da equação 2.4 é justificado. Outro fato importante é que, para baixas sucções, Abramento (1988), Wolle \& Hachich (1989) e Röhm (1992), observaram que os valores de $\phi^{b}$ eram maiores que $\phi^{\prime}$. Escario \& Saez (1987) e Fredlund et al. (1987), verificaram que, também para baixas sucções, os valores de $\phi_{\mathrm{b}}$ aproximavam-se de $\phi^{‘}$.

Delage et al (1987) apresenta resultados, onde os parâmetros c e ф’ variam com a sucção, obtidos através de ensaios triaxiais com sucção controlada em uma argila; O parâmetro c aumenta com a sucção e $\phi ’$ diminui com a sucção. Escário e Jucá (1989) apresenta resultados, em termos de c e $\phi$ ' versus sucção, de ensaios com sucção controlada realizados em uma argila e uma areia; Para a argila, ambos c e $\phi$, aumentaram com a sucção, mas para a areia, c aumentou com a sucção e o ângulo de atrito permaneceu constante. Teixeira (1996), para um colúvio arenoso (compactado) encontrou valores de $\phi$ ' constantes com o aumento da sucção e valores de coesão variando com a sucção conforme uma lei hiperbólica; Ainda segundo Teixeira (1996) para baixos valores de sucção é possível encontrar-se $\phi^{b}>\phi^{\prime}$. Observa-se assim que a sucção matricial desempenha uma clara função no incremento da coesão do solo, mas em termos de ângulo de atrito interno ( $\phi$ ') sua influência é bastante controvertida.

Quanto a forma da variação da coesão com a sucção várias propostas foram feitas, por exemplo: Escario (1988) (elipse de grau 2,5), Abramento (1988) (função potencial com expoente menor que a unidade). Rohm \& Vilar (1994) realizaram um estudo em um colúvio arenoso indeformado da região de São Carlos, Estado de São Paulo, no qual apresentaram resultados onde os valores de $\phi^{\prime}$ mostraram-se crescentes com a sucção $\left(27^{\circ}\right.$ e $32^{\circ}$ aproximadamente, para valores de sucção variando entre 0 e $400 \mathrm{kPa}$ ). O intercepto de coesão do solo apresenta valores crescentes com a sucção até valores de sucção de cerca de $200 \mathrm{kPa}$. A partir deste valor, acréscimos de sucção pouco influenciaram nos valores de c’. Segundo estes autores a lei hiperbólica é o melhor modelo que representa a relação entre sucção matricial e resistência ao cisalhamento. 
Estes autores também analisaram por que o modelo que melhor atende à relação entre resistência ao cisalhamento e sucção matricial desse solo é não-linear. Esse estudo baseou-se na análise da curva característica, da porosimetria, da distribuição de volume de vazios e da fotografia do plasma do solo. Em uma análise conjunta dessas quatro características do solo, observou-se que a não-linearidade da relação q versus sucção matricial parece estar relacionada com a microestrutura desse solo, que se mostra como esponjosa ou como um conjunto de "pipocas", permitindo a ocorrência de grandes poros (inter-aglomerados) e de minúsculos outros poros (intra-aglomerados). Foi verificado, pela análise conjunta dessas quatro características, que, para sucções matriciais até cerca de $200 \mathrm{kPa}$, parte da água do solo situa-se, ainda, nos vazios inter-aglomerados e, a partir desse valor, a água intersticial localiza-se, predominantemente, nos intraporos (no interior das “pipocas” constituídas de argilominerais aglomerados por óxidos hidratados de ferro e, ou, alumínio). Nos ensaios realizados, verificou-se que, exatamente para sucções a partir de $200 \mathrm{kPa}, \phi^{\mathrm{b}}$ tendia a ficar constante, aproximando-se de um valor nulo. Em ensaios realizados por Rohm \& Vilar (1995) foi observado que $\phi$ ‘ variava com a sucção e que, como já foi comentado, a resistência variava com a sucção de maneira não-linear.

Fredlund et al. (1987) admitem a não linearidade da resistência ao cisalhamento com a sucção matricial. Os autores ensaiando um solo de origem glacial em cisalhamento direto encontraram valores de $\phi^{b}$ decrescentes com a sucção. Ainda segundo Fredlund et al. (1987), para baixos valores de sucção, tem-se aproximadamente $\phi^{b}=\phi^{\prime}$.

Gan \& Fredlund (1995) apresentam resultados de ensaios triaxiais e de cisalhamento direto realizados em dois solos saprolíticos, ambos possuindo importantes vínculos inter partículas, ensaiados em condições saturadas e com sucção controlada. Os resultados apresentados em termos de resistência ao cisalhamento de pico apresentam uma envoltória curvilínea para baixos valores de tensão normal e linear para altos valores. A resistência a cisalhamento cresce com a sucção aplicada, atingindo valores máximos para valores de sucção entre 75 e $100 \mathrm{kPa}$. Ainda segundo estes autores, o caráter não linear das relações entre $\tau$ e sucção advém da curva característica de sucção do solo.

Com base nos estudos até aqui apresentados, as seguintes conclusões podem ser derivadas a respeito da resistência ao cisalhamento de solos não saturados: 
- A resistência ao cisalhamento se relaciona de maneira não linear com a sucção matricial (Lei Hiperbólica parece ser a mais representativa): para baixos valores de sucção temos aproximadamente $\phi^{b}=\phi^{\prime}$. Os valores de $\phi^{b}$ decrescem com o valor da sucção, de modo que a resistência ao cisalhamento do solo tende a um valor máximo para altos valores de $\left(\mathrm{u}_{\mathrm{a}}-\mathrm{u}_{\mathrm{w}}\right)$.

- O intercepto de coesão aparente do solo apresenta valores crescentes com a sucção matricial. As relações entre $\mathrm{c}$ e $\left(\mathrm{u}_{\mathrm{a}}-\mathrm{u}_{\mathrm{w}}\right)$ possuem formas assemelhadas àquelas prospostas para a resistência ao cisalhamento. A sucção matricial parece não apresentar um influência definida no valor do ângulo de atrito interno do solo.

\subsection{Técnica de translação de eixos}

Ao trabalhar-se com solos não saturados freqüentemente pressões inferiores a $100 \mathrm{kPa}$ são comuns, e estas pressões na água, inferiores a -100 kPa, fazem com que ela cavite invalidando assim o ensaio. A técnica de translação de eixos, proposta por Hilf (1956), surge como uma alternativa tanto na medida de pressão neutra quanto na imposição e controle da sucção em amostra de solo. Esta técnica baseia-se no princípio dos aparelhos de placas de pressão utilizados para definir as características de retenção de água pelo solo. Essa técnica consiste praticamente na mudança do referencial de pressão (a pressão atmosférica), ou seja, uma translação de eixo. Para isto aumenta-se a pressão no ar, donde certamente ocorrerá um aumento da pressão de água até valores mensuráveis pelos equipamentos convencionais de medida. A diferença ua - uw permanece a mesma, ou seja, a sucção permanece igual.

Para que a técnica seja exeqüível, é necessária instalação de uma placa porosa especial na base do equipamento de ensaio, de tal maneira que a base do corpo de prova fique em contato com ela. Esta placa porosa especial é fabricada com poros de pequenas dimensões, de sorte que ela permita o fluxo de água, porém não o de ar. A aplicação desta técnica usualmente envolve o controle de pressão de ar e o controle ou a medida da pressão de água. A sucção a ser imposta ao solo fica limitada à pressão de ar da placa porosa, que pode atingir até pressões de 15 bar. Segundo (Bocking \& Fredlund, 1980), caso exista ar ocluído na água do solo, os valores obtidos podem estar distorcidos, com uma sobreavaliação da sucção medida. Por isto ela é mais indicada quando existe a continuidade da fase gasosa através da amostra. Quando para graus de saturação altos 
(ou baixas sucções), onde a possibilidade de existir ar ocluído é grande, deve-se cogitar que a possibilidade de valores incorretos de sucção a partir desta técnica é grande.

\subsubsection{Alguns trabalhos desenvolvidos ao longo de um perfil de solo residual}

Maciel (1991) avaliou a influência do grau de intemperismo associado à ocorrência de efeitos de escala (dimensão de amostras), anisotropia e cimentação, em propriedades de resistência, permeabilidade e compressibilidade de um perfil de solo residual de gnaisse facoidal. A influência do grau de intemperismo no comportamento tensão versus deformação dos materiais analisados (solo residual maduro e solo residual jovem), se fez sentir, apenas, no valor da deformação de ruptura, menor para o solo maduro, indicando um comportamento frágil, típico de materiais cimentados. O solo saprolítico apresentou um comportamento plástico, indicando uma ausência, de cimentação criada pelo processo de intemperismo químico ou retida da rocha matriz.

Aleixo (1998) avaliou o comportamento tensão versus deformação de um perfil de solo residual de gnaisse tendo como objetivo verificar o efeito da direção de carregamento dos corpos de prova, do nível das tensões de confinamento, do grau de intemperismo, do arranjo estrutural dos grãos e dos efeitos do grau de saturação. O programa experimental constou de ensaios de compressão axial e hidrostática, sob condições drenadas de carregamento, utilizando o equipamento triaxial cúbico. Foram realizados também ensaios edométricos convencionais, de modo a se obter as características de compressibilidade do solo. Foram moldados corpos de prova a partir de blocos indeformados, paralelos e perpendiculares à estratificação observada no solo, o que possibilitou a análise dos resultados para direções distintas de carregamento. Para efeito de comparação sobre a relevância do arranjo estrutural dos grãos do solo, foram ensaiados também corpos de prova compactados dos mesmos materiais. As conclusões de Aleixo (1998), foram as seguintes:

- Quanto ao efeito da direção de carregamento a resistência em ambas as direções se mostraram semelhantes, sendo cerca de $10 \%$ maior na direção ortogonal à estratificação. Em relação a deformabilidade o solo carregado na direção ortogonal apresentou, em média, uma rigidez de $30 \%$ maior que na direção paralela à estratificação.

- Quanto ao grau de intemperismo, verificou-se que a resistência do solo maduro foi sempre maior que a do solo jovem para corpos de prova indeformados, tanto na 
umidade natural quanto saturados. No entanto, nos ensaios com material compactado, observou-se o oposto, ou seja, o solo jovem se mostrou com maior ressistência que o solo maduro. A deformabilidade volumétrica do solo jovem foi, em geral, maior que a do solo maduro para o material indeformado, e menor para o material compactado.

- Quanto ao efeito do arranjo estrutural dos grãos, notou-se que a resistência ao cisalhamento do solo jovem compactado foi maior que a do mesmo solo indeformado. Já para o solo maduro, o material indeformado mostrou-se com maior resistência que o material compactado. Segundo o autor isto pode ser explicado pela perda de cimentação provocada pela destruição da estrutura original dos grãos do solo.

- Quanto ao efeito da saturação, os corpos de prova ensaiados na umidade natural apresentaram maior resistência que na condição de total saturação. Isto se deve à presença de sucção significativa nos solos residuais na condição de umidade natural. Quanto à deformabilidade, o solo na umidade natural mostra em geral, maiores reduções de volume para um mesmo valor de tensão confinante efetiva durante o cisalhamento que o mesmo solo saturado.

- Quanto a verificação da anisotropia conforme, este autor concluiu que o solo residual jovem indeformado quanto a resistência apresentou um comportamento praticamente isotrópico e quanto a deformabilidade a direção Z (ortogonal à estratificação) apresentou menores deformações que as outras duas direções, evidenciando assim um comportamento anisotrópico quanto a deformabilidade. Para o solo maduro indeformado, tanto quanto a resistência e quanto a deformabilidade o solo apresentou um comportamento isotrópico.

Com respeito a interveniência do grau de intemperização na resistência, Sandroni \& Maccarini (1981) concluem, sobre uma campanha de 28 ensaios triaxiais em amostras indeformadas de solos residuais gnáissicos jovens, ricos em feldspato e pobres em mica, do Rio de Janeiro, que, muito claramente, o comportamento tensãodeformação é dependente tanto do nível de tensões como do índice de vazios, o qual reflete razoavelmente o grau de intemperização.

Pinto et al (1993) colocam que para os solos residuais, o valor da tensão de préadensamento obtido pelos conhecidos processos de Casagrande ou Pacheco Silva não está relacionado, geralmente, com a máxima tensão suportada pelo material ao longo de sua história, tendo sido chamada, muitas vezes de pseudo-tensão de pré-adensamento (ou virtual, conforme Vargas, 1971) e não tem o mesmo significado do que às argilas sedimentares. Pinto et al (1993) alertam que, como mostrou Vaughan (1985), a própria 
maneira de apresentação dos ensaios em gráfico mono-log pode falsear os dados e sugerir valores anômalos de pressão de pré-adensamento em função da descontinuidade de comportamento, forçada pelas escalas.

Machado (1998), apresentou resultados de ensaios triaxiais convencionais, de compressão confinada e triaxiais com controle de tensão, realizados em amostras saturadas e com controle de sucção, em corpos de prova indeformados coletados ao longo de um perfil típico de solo da cidade de São Carlos - SP. A partir dos dados obtidos, foi feito um estudo do comportamento de deformação e resistência do solo, em condições não saturadas, ao longo de todo o perfil amostrado. Para o solo residual de arenito foi realizado também um estudo das suas principais características de elastoplasticidade, para a condição saturada e para o caso dos ensaios realizados com controle de sucção. Foi mostrado que as superfícies de plastificação obtidas para o solo podem ser ajustadas de modo razoável pela superfície de escoamento do Cam-Clay modificado, utilizada nos modelos de Alonso et al. (1990) e Balmaceda et al. (1992). A forma da superfície de plastificação não apresentou indícios de mudança quando do seu deslocamento, seja por um processo de encruamento do solo ou pelo seu espraiamento em planos com valores crescentes de sucção. Ainda a partir dos dados analisados, mostra-se que a adoção de uma lei de fluxo associada para o solo pode conduzir a resultados aceitáveis e mudanças na posição da superfície de plastificação do solo (por encruamento ou variações no valor de sucção) parecem não interferir de maneira significativa na natureza da lei de fluxo do material. O espraiamento das superfícies de plastificação do solo com relação a sucção, obtido a partir dos ensaios em trajetórias múltiplas de tensão, é comparado com aquele previsto a partir de ensaios triaxiais e de compressão confinada com controle de sucção realizados pelo próprio autor apresentando bons resultados. Um modelo constitutivo foi proposto para representação do comportamento do solo em condições não saturadas. Uma nova superfície de plastificação e uma nova lei de fluxo (não associada) são propostas para o solo, conseguindo-se uma melhor previsão dos pontos de escoamento situados à esquerda da projeção da linha de estados críticos e diminuindo-se os valores dos desvios angulares dos vetores de incrementos de deformação plástica. No modelo constitutivo proposto, a superfície de escoamento LC do solo foi obtida levando-se em consideração não somente os valores da pressão de pré-adensamento, mas também os valores de $\lambda_{\mathrm{s}}$. Os modelos constitutivos proposto e de Balmaceda et al. (1992) foram utilizados na simulação dos ensaios de laboratório, obtendo-se bons resultados. 


\subsection{Curvas de Plastificação de Modelos baseados na Teoria dos Estados Críticos}

\subsubsection{Critérios para a identificação da Tensão de Escoamento}

Um fato importante, para o estudo do comportamento dos solos, é justamente a dificuldade de definir-se um limite preciso entre a zona de deformações elásticas e de deformações plásticas, ou seja, os pontos onde começa a ocorrer o escoamento (cedência) do material. A Figura 2.32 ilustra resultados típicos obtidos a partir de ensaios de laboratório normalmente adotados em mecânica dos solos. A Figura 2.32 (a) ilustra as trajetórias de tensões seguidas nos diferentes ensaios. Na Figura 2.32 (b) é apresentada uma curva típica de compressão isotrópica, com o seu respectivo ponto de escoamento Y1. Este mesmo ponto está representado na Figura 2.32 (a), no espaço (q,p’). Na Figura 2.32 (c) é apresentada uma curva típica de ensaio de compressão confinada, com o seu respectivo ponto de escoamento $\mathrm{Y}_{2}$, enquanto que na Figura 2.32 (d) é apresentada uma curva típica obtida a partir da realização de um ensaio triaxial convencional não drenado, com o seu ponto de escoamento correspondente $\mathrm{Y}_{3}$. A curva tracejada apresentada na Figura 2.32 (a) unindo os pontos $\mathrm{Y}_{1}, \mathrm{Y}_{2}$ e $\mathrm{Y}_{3}$ nos dá uma idéia da superfície de plastificação do solo.

A definição dos pontos de escoamento para solos não ocorre de maneira tão imediata quanto para metais, envolvendo grande subjetividade na sua determinação. Pode-se dizer, contudo, que amostras indeformadas possuem pontos de escoamento mellor definidos do que amostras moldadas em laboratório, devido à estrutura adquirida durante a sua história de tensões em campo (Wood, 1992). Devido à estas dificuldades, diferentes procedimentos têm sido adotados na definição de superfícies de escoamento para solos. 


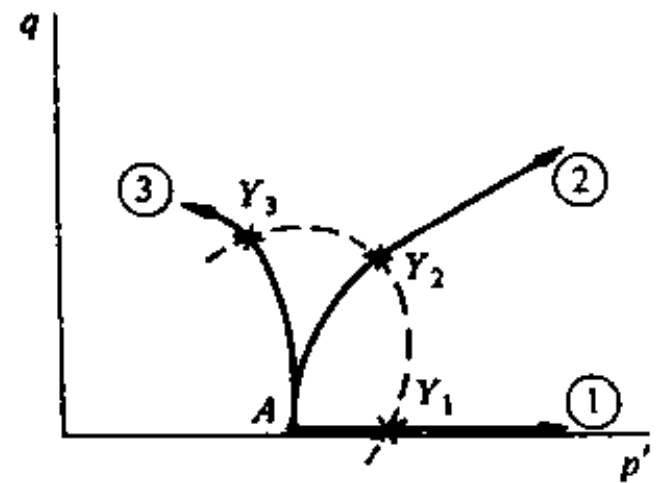

(a)

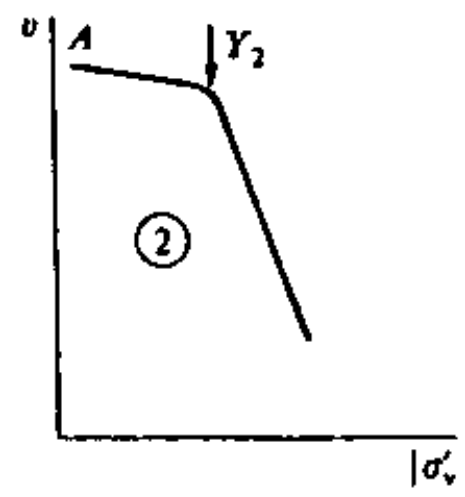

(c)

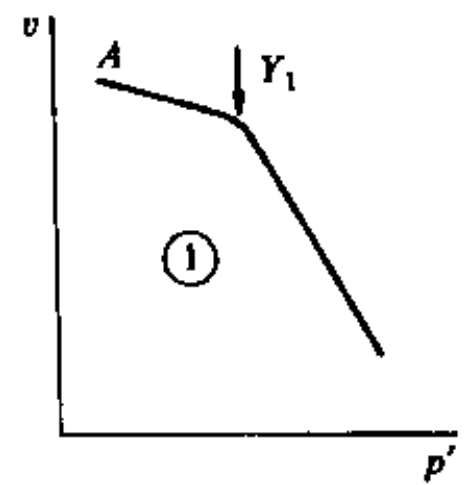

(b)

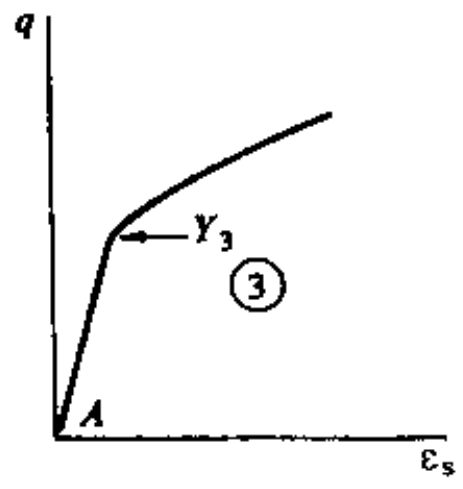

(d)

Figura 2.32 - (a) Trajetórias de tensões no espaço q;p’, (b) teste de compressão isotrópica (1), (c) teste de compressão confinada (2) e (d) teste de compressão triaxial não drenado (3). (Wood, 1992).

Tavenas et al. (1979) apresentam resultados de vários ensaios triaxiais drenados, com controle de tensão, realizados em quatro argilas do leste do Canadá, levemente adensadas e chegam a conclusão que a energia de deformação é um excelente parâmetro para a definição da superfície de escoamento de um solo. A energia de deformação pode ser calculada pela expressão 2.6.

$$
\mathrm{W}=\int\left(\sigma_{1} d \varepsilon_{1}+\sigma_{2} d \varepsilon_{2}+\sigma_{3} d \varepsilon_{3}\right)
$$

Onde: $\sigma_{1}, \sigma_{2}, \sigma_{3}$ e $\varepsilon_{1}, \varepsilon_{2}, \varepsilon_{3}$ são as tensões e deformações principais, respectivamente. Tavenas et al. (1979) determina o ponto de escoamento através da mudança na inclinação da curva de energia dissipada versus p' ou energia dissipada versus tensão axial. 
Graham et al (1983) propõem o traçado de curvas $S_{w}$ versus $W$ onde $S_{w}$ é definido pela equação (2.7).

$\mathrm{S}_{\mathrm{w}}=\sqrt{q^{2}+p^{2}}$

Lade \& Kim (1988) admitem que as superfícies de plastificação do solo possuem formas semelhantes às curvas de igual trabalho plástico. Esta hipótese é bastante útil não só na averiguação da superfície de plastificação do solo originada em sua história de carregamento em campo, mas também serve como ferramenta para avaliar mudanças na forma da superfície de plastificação ocasionadas com o progresso da plastificação do material. Estas mudanças na forma da superfície de escoamento podem ser verificadas em muitos solos em que a estrutura desempenha um papel fundamental no ser comportamento ou no caso da existência de algum agente cimentante. Com a continuada plastificação do solo, a influência destes fatores tende a desaparecer, provocando mudanças na forma da superfície de escoamento original.

Para solos residuais vários métodos tem sido propostos para identificar a tensão de cedência (escoamento devido a quebra da estrutura cimentada). Vaughan et al. (1988) mostra que as tensões de cedência são melhor visualizadas ou determinada através da escala logarítimica (ln $\sigma^{\prime}$ versus $\ln \varepsilon_{a}$ ).

\subsubsection{Modelo Cam-Clay}

O modelo Cam-Clay é o resultado de investigações laboratoriais minuciosas feitas pelo grupo de mecânica dos solos da Universidade de Cambridge (Roscoe et al. (1958), Roscoe \& Burland (1968) e Schofield \& Wroth (1968)). Roscoe et al. (1958) formularam uma teoria tendo como fundamentação a teoria de estados críticos para solos saturados. Surge então o modelo Cam-Clay (Roscoe et al. (1963), Shofield \& Wroth (1968)), baseado nos conceitos da mecânica dos estados críticos e no trabalho de Drucker et al. (1957) e em seguida o modelo Cam-Clay modificado Roscoe \& Burland (1968). Muitas outras versões do Cam-Clay, original e modificado, têm sido propostas nos últimos anos. Wood (1992) apresenta em seu livro uma abordagem atual e ilustrativa do Cam-Clay juntamente com a mecânica dos solos dos estados críticos. 
O modelo Cam-Clay original foi formulado de tal maneira que as equações constitutivas superestimavam os valores de incrementos de deformação para pequenos valores de tensão cisalhante. Além disto a forma original de sua superfície de escoamento, em conjunto com a hipótese de fluxo associado, acabavam por prever deformações cisalhantes em compressão isotrópica.

O Cam-Clay é um modelo elastoplástico com endurecimento isotrópico e potencial plástico coincidente com a função de plastificação, cujas relações tensãodeformação envolvem quatro parâmetros característicos do material: $\lambda, \kappa, \mathrm{M}$ e G'. É um modelo desenvolvido para a condição de carregamento assimétrico com base na observação experimental de ensaios triaxiais e pode ser melhor descrito no espaço (q,p'). Os parâmetros $\lambda$ e $\kappa$, correspondem respectivamente às inclinações dos trechos virgem de compressão e da curva de recuperação elástica de descarregamento / recarregamento. Pode-se dizer que a inclinação $\lambda$ é análoga ao índice $\mathrm{c}_{\mathrm{c}}$, equanto a inclinação k é análoga ao índice de expanção $C_{e}$.

A projeção da linha de estados críticos no espaço (q; p’) é linear e tem como equação :

$$
\mathrm{Q}=\mathrm{M} \cdot \mathrm{P}
$$

Onde M é um dos parâmetros do modelo e obedece a equação (2.9), para o caso de compressão triaxial, e a equação (2.10) para o caso de extensão triaxial.

$$
\begin{aligned}
& \mathrm{M}=\frac{6 \operatorname{sen}(\phi)}{3-\operatorname{sen}(\phi)} \\
& \mathrm{M}=\frac{6 \operatorname{sen}(\phi)}{3+\operatorname{sen}(\phi)}
\end{aligned}
$$

As equações (2.11) e (2.12) apresentam as superfícies de escoamento propostas, respectivamente, para o Cam - Clay original e modificado.

$$
\mathrm{F}\left(\mathrm{p}^{\prime}, \mathrm{q}\right)=\mathrm{p}^{\prime} \ln \left[\frac{p_{0}^{*}}{p^{\prime}}\right]-\frac{q}{M}=0
$$




$$
\mathrm{f}\left(\mathrm{p}^{\prime}, \mathrm{q}\right)=\mathrm{p}^{, 2}-\mathrm{p}^{\prime} \mathrm{p}_{0} *+\frac{q^{2}}{M^{2}}=0
$$

$\mathrm{p}_{0}{ }^{*}$ representa a tensão de pré-adensamento isotrópica do solo (utilizada na função de encruamento), obtida utilizando-se as equações (2.11) e (2.12) e fazendo-se q $=0$.

Deve-se levar em conta que o modelo Cam-Clay modificado (e o original) foram desenvolvidos para representar o comportamento de argilas levemente pré-adensadas, as quais apresentam encruamento positivo (diminuição de volume) durante a plastificação. O modelo tem apresentado diversas limitações na representação do comportamento de solos os quais tendem a apresentar comportamento do tipo "strain - softening”, como os solos altamente pré-adensados. O Cam-Clay se comporta melhor para solos préadensados isotropicamente, já que solos adensados em uma trajetória $\mathrm{K}_{\mathrm{o}}$ possuem uma superfície de escoamento centrada na linha $\mathrm{K}_{\mathrm{o}}$, e não no eixo p’.

\subsubsection{Modelo de Alonso et al (1990)}

Alonso et al (1987) apresentaram conceitos sobre a influência da sucção na variação de volume (colapso e pequena e moderada expansão), limites elásticos, comportamento do solo submetido a diferentes caminhos de tensões, utilizando teorias elastoplásticas.

Qualitativamente Alonso et al. (1987) explicaram o comportamento dos solos não saturados no plano isotrópico p “versus” sucção, limitando a região de comportamento elástico por duas linhas: LC (“loading colapse”) e SI ("suction increase”).

A curva de escoamento LC é aquela formada pelos pontos de escoamento para o carregamento isotrópico p em diferentes valores de sucção, constantes em cada carregamento, como mostra a Figura 2.33. 


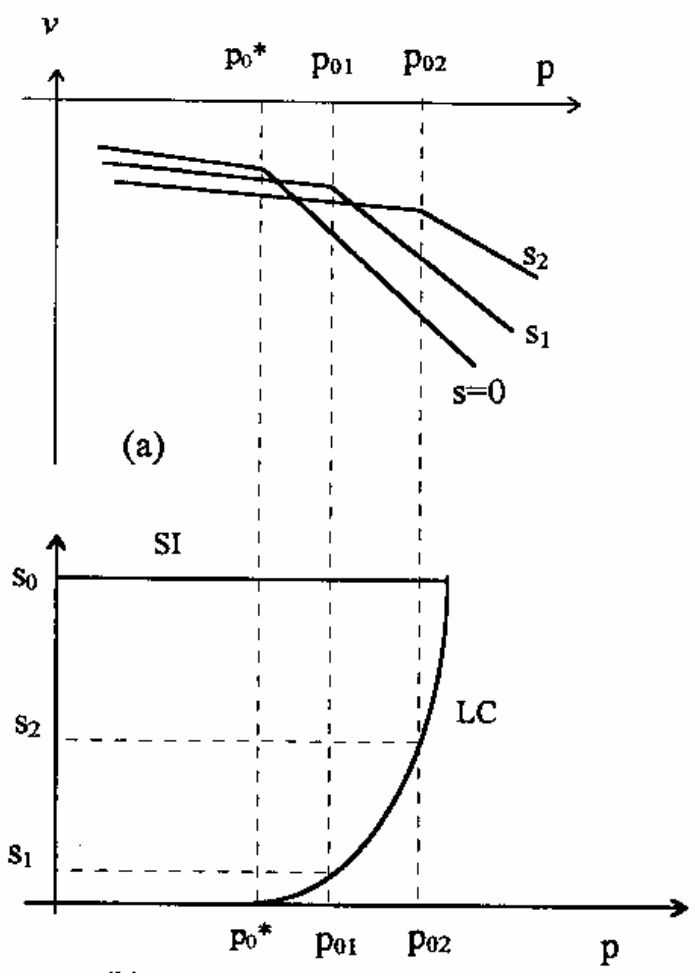

(b)

Figura 2.33 - (a) Caminhos de tensões para carregamento p e sucção (s) = constante (b) Superfícies de escoamento SI e LC (Alonso et al., 1987)

SI é uma linha horizontal no mesmo plano isotrópico p "versus” s e que passa por $\mathrm{s}_{0}$. $\mathrm{O}$ valor de $\mathrm{s}_{0}$ é idealizado como sendo a máxima sucção que o solo esteve submetido. Este valor é considerado o mesmo para qualquer estado de tensão p.

Alonso et al. (1987) utilizaram o modelo Cam Clay Modificado associado aos efeitos da sucção para explicar o comportamento dos solos não saturados.

Alonso et al. (1990) descrevem um modelo constitutivo para solos não saturados que é a formulação matemática dos conceitos de ALONSO et al (1987) para estados de tensões isotrópicos e triaxiais.

Alonso et al. (1990) realizaram a formulação de forma que quando o solo tornase saturado o modelo se reduz ao modelo Cam Clay Modificado.

O modelo propõe que a curva de escoamento no plano (p,q) para um corpo de prova com sucção constante descreve uma elipse e passa pelos pontos de tensão de pré adensamento isotrópico $\mathrm{p}_{0}$ relacionado com a superfície de escoamento LC, como pode-se ver na Figura 2.34.

A inclinação da linha de estados críticos $\mathrm{M}$ foi considerada inalterada com a sucção, ou seja, seu valor é o mesmo para a condição saturada ou não saturada com 
sucção constante. O aumento da resistência do solo com a sucção foi considerado através do parâmetro k. Este parâmetro descreve o aumento da coesão com a sucção e pode ser encontrado conhecendo-se $\mathrm{p}_{\mathrm{s}}$. Este último resultante do prolongamento da linha de estados crítico com uma determinada sucção s, ao eixo p.

$$
P=-P_{s}=-k . s
$$

A elipse passa pelos pontos - $\mathrm{p}_{\mathrm{s}}(\mathrm{s})$ e $\mathrm{p}_{0}(\mathrm{~s})$ e é dada pela função:

$$
q^{2}=M^{2}\left(p+p_{s}\right) \cdot\left(p_{0}-p\right)
$$

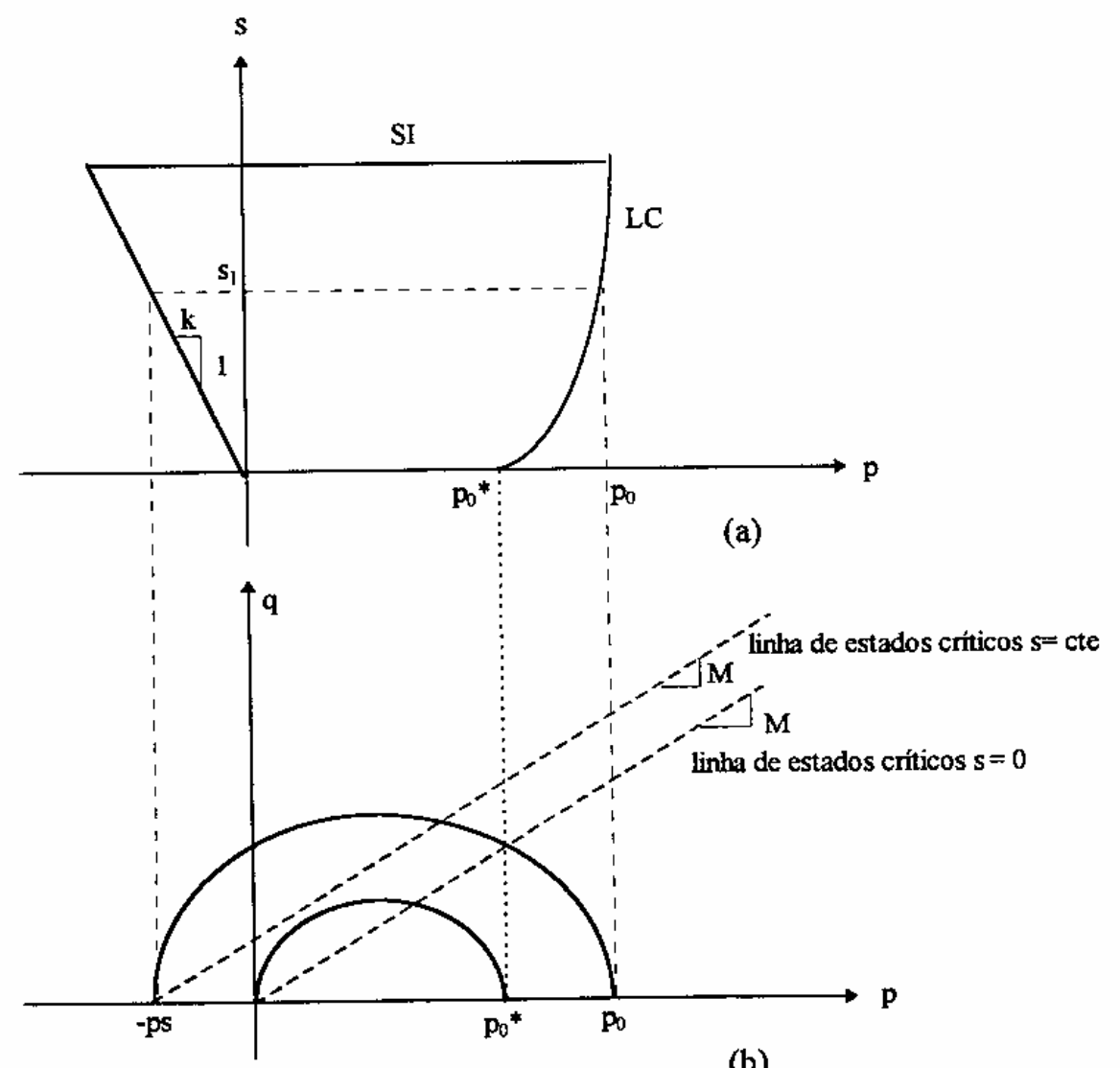

(b)

Figura 2.34 - Superfícies de escoamento nos espaços: a) (p,q) e (b) (p,s) (Alonso et al., 1990). 


\section{3 - MATERIAIS E MÉTODOS}

Para a realização deste trabalho efetuaram-se diversos ensaios geotécnicos com amostras de um perfil típico de solo residual de gnaisse da cidade de Viçosa - MG, além de ensaios de caracterização porosimétrica, mineralógica e micro-estrutural. Nos itens seguintes, descrevem-se características fisiográficas da área de ocorrência do citado solo, bem como os métodos de ensaios empregados no transcorrer da pesquisa.

\subsection{Características gerais da região de Viçosa}

\subsubsection{Localização geográfica}

O planalto de Viçosa encontra-se em um planalto deprimido, em relação às cadeias de montanhas que o limitam, em forma de sela situada entre o Planalto do Alto Rio Grande (Serra da Mantiqueira) e os prolongamentos da Serra do Caparaó e Serra do Brigadeiro (MOREIRA, 1965; REZENDE, 1971).

Geograficamente, o centro microrregional de Viçosa está inserido no Planalto de Viçosa, incrustado na serra de São Geraldo, apresentando uma área de $279 \mathrm{~km}^{2}$ com

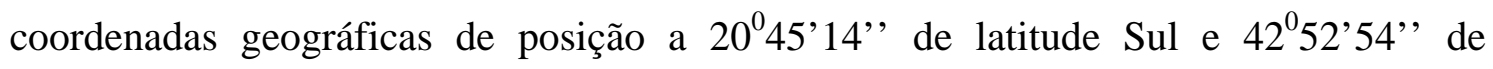
longitude Oeste de Greenwich, a uma altitude de $750 \mathrm{~m}$.

Este município localiza-se na Zona da Mata mineira. Limita-se a oeste com os municípios de Porto Firme e Guaraciaba; a leste, com os Municípios de Cajuri e São Miguel do Anta; ao norte, com o município de Teixeiras e ao Sul com os municípios de Paula Cândido e Coimbra. O acesso pode ser realizado servindo-se da BR-120 (Ponte Nova - Ubá) ou MG - 60 (Viçosa - Ubá).

\subsubsection{Dados climatológicos}

Segundo Azevedo (1999), o clima de Viçosa enquadra-se no tipo Cwa (Clima Tropical de Altitude de Verões Brandos), na classificação de Koppen, isto é, clima mesotérmico caracterizado por inverno seco e verão chuvoso. A temperatura média 
anual é de $19^{\circ} \mathrm{C}$, com estação mais fria correspondente aos meses de maio a agosto, e chuvosa de outubro a março. A média anual da umidade relativa do ar é em torno de 78 \%. A precipitação media anual é da ordem de 1200 mm a 1400 mm.

\subsubsection{Geologia}

Segundo Guimarães (1996), Viçosa está situada no Complexo Cristalino, que é constituído de rochas muito antigas. Estas rochas foram palcos de vários eventos geológicos, como metamorfismo de alto grau e injeção de material básico, principalmente, em forma de diques. O metamorfismo de alto grau, atuando sobre granitos, gerou rochas gnáissicas e, com a refusão parcial das rochas, formaram-se materiais de natureza híbrida metamórfica-ígnea, como migmatitos. Associados ao alto grau metamórfico, encontram-se os micaxistos, constituídos de minerais micáceos, e os gnaisses, constituídos de micas e anfibólios, com quartzo e feldspatos, ocorrendo em ambos. Estas rochas caracterizam-se pela presença de estruturas particulares, como xistosidade e foliação gnáissica, que facilitam o seu intemperismo. O processo de intemperismo atua sobre as micas, que podem ser alteradas por minerais de camadas 2:1, expansíveis pela perda de potássio. Em adição, podem, ainda, alterarem-se os minerais ferromagnesianos, ocorrentes nos diques de diabásio comuns na região, o que, em ambientes conservativos, acumula ferro e magnésio, também promovendo a formação de argilominerais 2:1. Em Viçosa, os minerais 2:1 encontrados são as micas, ocorrendo como biotita, nos solos saprolíticos e de terraço.

A geologia da microrregião apresenta rochas do Embasamento GranitoGnáissico Indiviso referentes ao período Pré-cambriano. Elas são constituídas de gnaisses moderamente indiferenciados à bastante alterados, apresentando níveis quartzosos intercalados a níveis micáceos. Observa-se também, presença de intrusões de rocha metabásica, que às vezes são concordantes e outras discordantes com a foliação da rocha local (LUÍS, 2000). Sobre essas rochas, que pertencem ao Complexo Cristalino, encontra-se uma cobertura terciária pouco espessa e ao longo dos vales e das vias fluviais aparecem os sedimentos quaternários, que constituem os depósitos aluvionares de caráter argiloso, argilo-arenoso ou arenoso. Morfoestruturalmente, a região integra o Domínio dos planaltos Cristalinos Rebaixados, situando-se entre as escarpas da Serra da Mantiqueira, a leste, e a Serra do Espinhaço (Domínio do Planalto Proterozóico), ao oeste. As condições morfoclimáticas dessa microrregião são, caracteristicamente, as das zonas intertropicais úmidas, em que predominam os 
processos químicos e biogênicos, os quais atuam associados a processos mecânicos. Da ação conjugada desses processos resulta um manto de alteração (alterito) bastante espesso, nas áreas de declividades fracas a médias (IGA, 1976).

Segundo Baptista et al (1997), o complexo da Mantiqueira, de origem Proterozóica Inferior, ocupa a maior parte da região de Viçosa e compõe-se de gnaisses bandados de composição tonalitotrondjemítica e granito-granodiorítica com intercalações freqüentes de corpos tabulares de metabasitos. Metaultrabasito, rocha calcosilicática, metagabro e raros quartzitos estão subordinados. Diques de rochas básicas/metaultrabásicas encontram-se, também, encaixados entre os gnaisses do Complexo Mantiqueira. As foliações são marcantes e de formas onduladas, cuja principal orientação é NW/NE, as fraturas e os lineamentos têm orientação NW/NE e na maioria das vezes estão preenchidas por veios de quartzo e ferro.

\subsubsection{Geomorfologia}

No que se refere ao relevo, a microrregião pertence ao Domínio Tropical Atlântico de Mares de Morros e caracteriza-se por sua topografia fortemente acidentada, apresentando proporções reduzidas de áreas planas, quase restritas aos terraços e leitos maiores. Predominam, no município, colinas convexas e convexo-côncavas, alinhadas em formas de espigões, bastante seccionadas pela rede de drenagem. Os topos são aplanaidos, ou abalados, e funcionam como divisores de água (interflúvios) para as pequenas bacias de drenagem. As vertentes apresentam ondulações e são bastante ravinadas. As elevações e os fundos de vale formam dois conjuntos pedológicos distintos do planalto de Viçosa. Nas elevações, dominam os Latossolos e CambsolosLatossólicos, ao passo que os fundos de vale apresentam, nos terraços, solo Podzólico Câmbico de textura muito argilosa, sendo os leitos maiores constituídos por solos aluviais de textura geralmente fina, algumas vezes em associação com hidromórficos (CORRÊA, 1984). Em linhas gerais, as vertentes desenvolvem-se em seqüência côncavo-convexo-topo e partes íngremes, conforme mostra a Figura 3.1, constratando com os fundos de vale, também com relação às características pedológicas (REZENDE, 1971; KER e SCHAEFER, 1995). A concordância dos topos das elevações e a ocorrência de alguns topos planos, relativamente extensos, sugerem a existência pretérita de um chapadão. O profundo manto de intemperismo e a virtual ausência de afloramentos de rochas reforçam esta idéia. A área foi, e está sendo, dissecada pelo entalhamento da drenagem, vindo da parte costeira. A profundidade dos depósitos de 
terraço sugere que esta região foi recortada por “canyons”. Estes foram posteriormente colmatados pelo material dos terraços. Os morros em "meia laranja” que se formaram, estão sendo agora dissecados, através do processo de ravinamento.

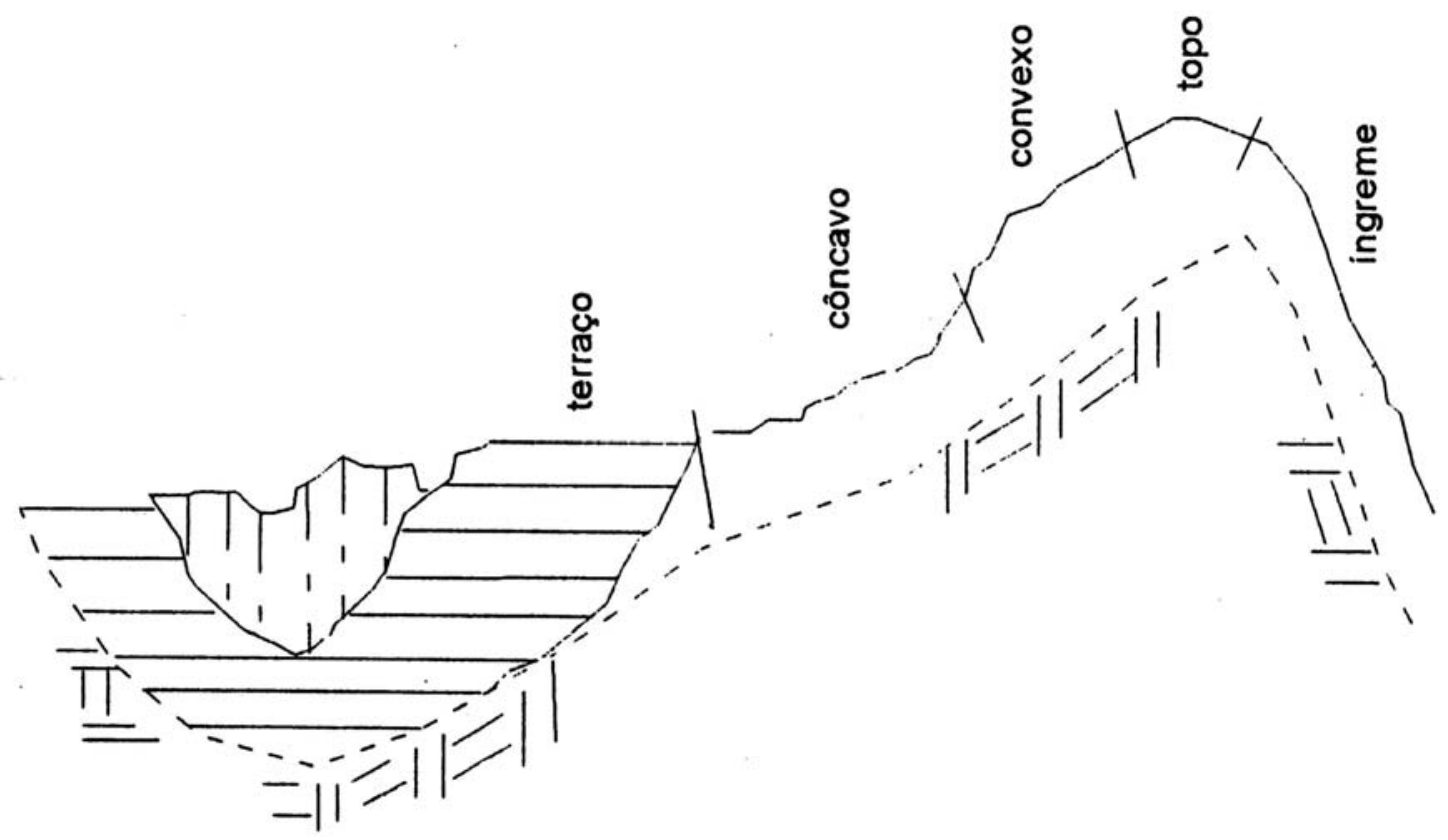

Figura 3.1 - Esquema de conformação típica da vertente de Viçosa - MG, assinalando-se seus segmentos (RESENDE, 1971).

Segundo Resende 1982, ao observar um perfil na Zona da Mata, em Minas Gerais (solos desenvolvidos de gnaisse), podem-se distinguir os seguintes horizontes:

a) Horizonte A - Apresenta-se como um horizonte escurecido e constitui a camada arável do perfil.

b) Horizonte B - Apresenta-se como uma camada bastante espessa, de coloração amarela, vermelha ou vermelha-amarelada.

c) Horizonte C - Apresenta-se como uma camada rósea, na parte superior, e acinzentada, na parte inferior, que se estende até a rocha. Nesse horizonte, os vestígios da estrutura da rocha são, ainda, visíveis.

\subsubsection{Pedologia}

A exposição circusntanciada dos dados e as informações das classes de solos apresentadas a seguir é uma compilação dos trabalhos de Carvalho Filho (1989) e Ramalho (1994), incorporando-se também uma descrição de Azevedo (1999), com 
citação mineralógica das classes de solos. Neste item serão descritos somente os tipos de solos superficiais, referentes ao campo de estudo da Pedologia. Além dos solos superficiais, existem os solos saprolíticos que são muito comuns e de grande importância geotécnica na cidade de Viçosa. Estes solos, por não pertencer ao campo de estudo da pedologia, serão descritos posteriormente, quando serão apresentados os dois horizontes utilizados neste estudo.

\subsubsection{Latossolo Vermelho-Amarelo (LV)}

Solo de grande expressão territorial no relevo de Viçosa, bastante intemperizado e lixiviado. Engloba os solos provenientes de material de origem pré-intemperizado de gnaisse, podendo alcançar algumas dezenas de metros na seqüência de horizontes A-BC. Normalmente apresentam textura areno-argilosa a argilo-arenosa e aspecto bastante poroso. Situam-se nos topos estreitos e nas pedoformas côncavo-convexas e são formados em áreas de antigos pediplanos e mineralogicamente apresentam predominância de caulinita, goethita, hematita e traços de gibbsita.

\subsubsection{Latossolo Vermelho-Amarelo Variação Una (LVU)}

Pode ser encontrado no topo de elevações com relevo plano. Apresenta um expressivo horizonte $\mathrm{B}$, profundo, poroso e bem drenado, de textura argilosa a muito argilosa, o que lhe confere comportamento plástico e pegajoso. Apresenta pouca diferenciação entre os horizontes A-B-C, e caracteriza-se pela cor brunada do horizonte B. Mineralogicamente, possue alto teor de ferro e observa-se a presença de quartzo na fração silte, bem como caulinita e gibbsita nas frações silte e argila.

\subsubsection{Cambissolo (CL)}

Ocorrem, predominantemente, nas vertentes mais íngremes do relevo. São solos rasos onde: o horizonte $B$, possue uma espessura em torno de $50 \mathrm{~cm}$, o horizonte $C$ é de pequena espessura e a rocha está situada perto da superfície. Como acontece com os solos LV, devido ao intenso processo de intemperismo químico, esta classe de solos também não apresenta mais minerais primários que existiam na rocha original, o gnaisse, sendo encontrados somente os seguintes minerais secundários: caulinita, goethita, hematita e gibbsita. Apresentam uma relação silte/argila maior que os outros solos da paisagem e, por possuírem um horizonte B incipiente, a textura varia muito 
pouco ao longo do perfil, sendo comuns modalidades areno-argilosa a muito argilosa. Os cambissolos estão associados nas elevações com os Latossolos e nas partes baixas com o Podzólico Vermelho-Amarelo com B Bruno Micáceo localizado no piso das ravinas.

\subsubsection{Podzólico Vermelho-Amarelo (PV)}

São formados por sedimentos fluviais originários de solos desenvolvidos de gnaisse Pré-Cambriano. São solos que apresentam o horizonte $B$ textural pela translocação de argila do horizonte A para o horizonte B. Segundo CORRÊA (1984), corresponde a uma superfície plana elaborada em ambiente flúvio-lacustre e, posteriormente, dissecada pela rede de drenagem atual, evidenciando os terraços.

Apresentam estrutura em blocos e cerosidade formada pela deposição da argila na superfície dos agregados no horizonte B fluvial. Esta cerosidade os protege da ação de agentes erosivos. Mineralogicamente, apresentam quartzo, caulinita e gibsita nas frações silte e argila; na fração areia, apresentam também pseudomorfos de micas. A cor avermelhada e amarelada é devida aos óxidos de ferro: hematita e goethita.

\subsubsection{Podzólico Vermelho-Amarelo com B Bruno micáceo (PVB)}

Ocupam posições mais baixas da paisagem com certa declividade, em ambientes conservadores e em condições de drenagem ineficientes, onde os processos de erosão não são intensos a ponto de formarem Cambissolos Latossólicos ou Latossolos. São solos mais jovens e férteis, rejuvenecidos pela erosão geológica. Associam-se, nas laterais das ravinas, com Cambissolos ou Cambissolos Latossólicos. Estes solos apresentam como características importantes o aspecto lustroso e de brilho graxo, conseqüência da presença de caulinita pseudomorfa.

\subsubsection{Cambissolo Latossólico (CL)}

Os Cambissolos Latossólicos localizam-se nas elevações, normalmente nas partes mais íngremes da paisagem, apresentando um Horizonte A com alguns centímetros de espessura, Horizonte $\mathrm{B}$ incipiente maior que $50 \mathrm{~cm}$. Com uma declividade acentuada, são formados a partir do rejuvenecimento dos Latossolos pela erosão geológica. São solos rasos e expostos freqüentemente à erosão com o manto de 
intemperismo C bem profundo, pois são encontrados normalmente nas partes íngremes do relevo, podendo também ser encontrados nas bordas das ravinas anfiteátricas.

\subsubsection{Solos Hidromórficos (HI)}

São solos de topografia plana, que se encontram no leito maior das linhas de drenagem, às margens dos cursos d’água ou partes baixas do terreno sob condição de saturação de água ou alagamento temporário, formados a partir do pequeno volume d’água que drenam os vales. Estes solos apresentam, como características principais, cores acinzentadas devido às condições de hidromorfismo a que estão sujeitos. Nota-se que as características determinadas pela ação do clima e da vegetação não se desenvolveram integralmente, em virtude da restrição imposta pelo excesso de umidade permanente ou temporário do solo durante períodos variáveis do ano.

\subsection{Perfil de solo escolhido}

A Microrregião de Viçosa, município do Estado de Minas Gerais, situa-se no domínio do Complexo Cristalino Brasileiro constituída por rochas pré-cambrianas, com predominância de gnaisse e anfibolitos. O perfil considerado neste trabalho é desenvolvido de gnaisse, e se compõe das duas ocorrências de maior relevância na Microrregião de Viçosa, o Latossolo Vermelho-Amarelo (horizonte B), pedogenizado, e o Saprolito (horizonte C).

O perfil de solo apresenta-se com um horizonte B com forte estruturação, em geral, microgranular e, em alguns casos, em blocos subangulares (Schaefer, 1995). A textura dos solos é bastante variável, com perfis porosos e permeáveis, com índice de vazios em geral superiores a 1 (Azevedo, 1999), possuindo tonalidades de cores vermelhas até amarelas, com partículas de diâmetros menores que $2 \mathrm{~mm}$, e com propriedades geotécnicas variáveis. A fração argila desses solos, nas condições prevalecentes do planalto de Viçosa, são dominantemente cauliníticas e oxídicas (Ker e Schaever, 1995). Subjacente a essa camada superficial, surge outra que diferencia-se pela cor rósea ou ligeiramente mais avermelhada, podendo ainda ocorrer mistura de diversos matizes, o horizonte C. Neste há aumento dos teores das frações silte e areia, bem como a presença de partículas micáceas e flocos grandes de caulinita pseudomorfa de biotita (Pinto, 1971). 
Na Figura 3.2 mostra-se o perfil de solo estudado e na Figura 3.3 mostra-se o croqui esquemático do perfil. A seguir descreve-se com mais detalhes os dois materiais utilizados no estudo.

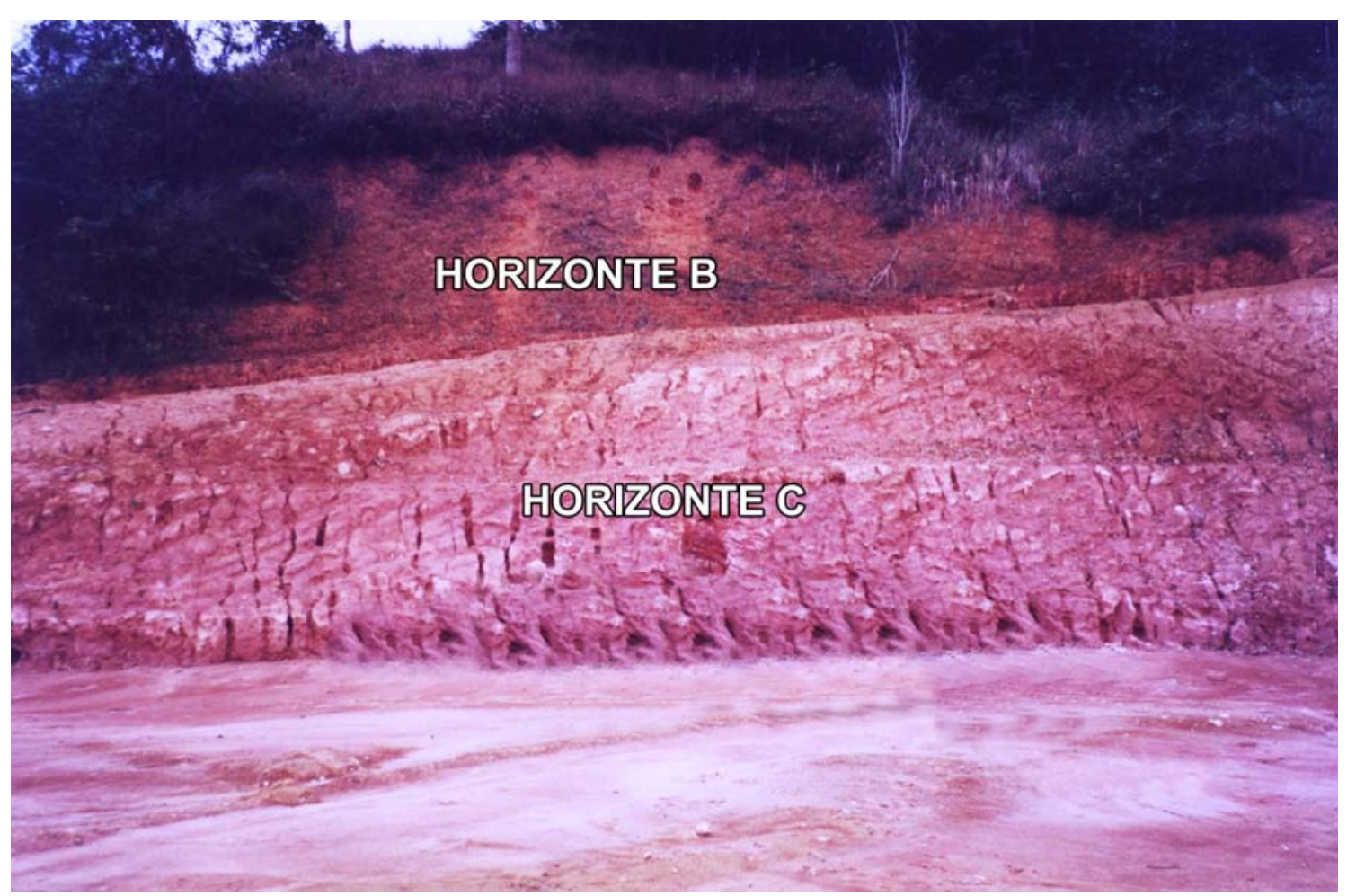

Figura 3.2 - Perfil de solo estudado.

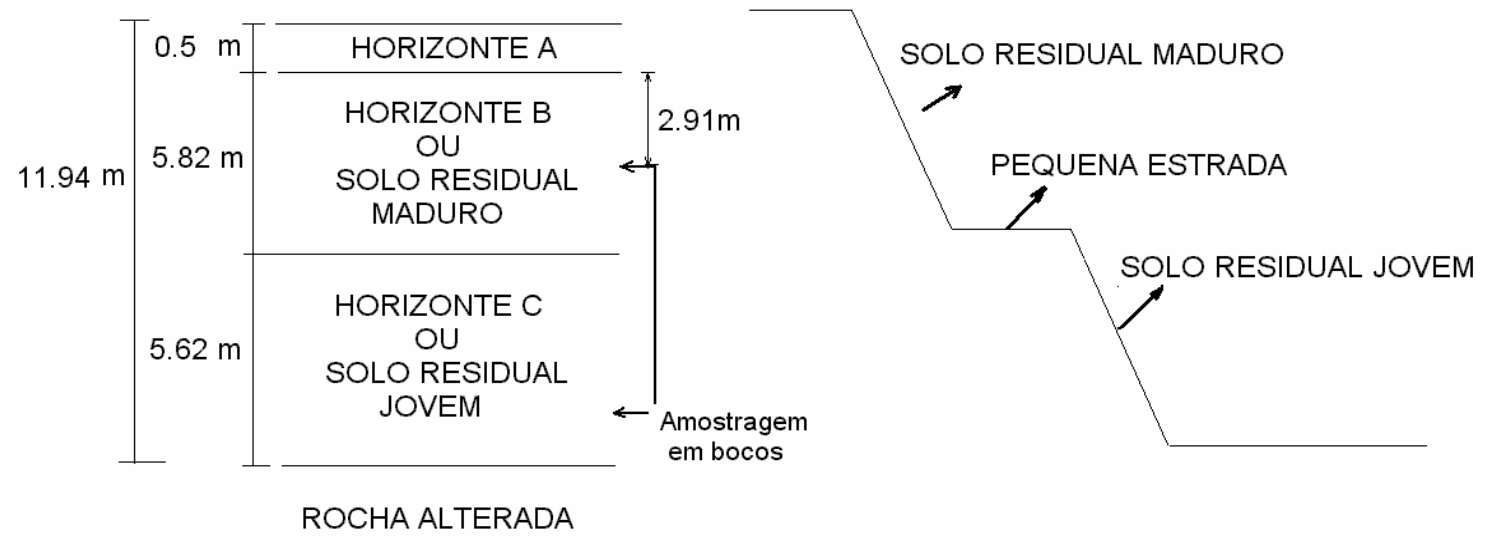

a) Vista frontal

b)Vista lateral

Figura 3.3 - (a e b) Croquis da vista frontal e lateral do perfil. 


\subsubsection{Latossolo Vermelho - Amarelo}

Como já referido anteriormente, este solo é de grande expressão territorial no relevo de Viçosa. Segundo Azevedo (1999), são bastante intemperizados e lixiviados, de perfis profundos ou muito profundos de seqüência de Horizontes A-B-C, com diferenciação dos horizontes e apresentam o Horizonte B latossólico. São provenientes do material de origem pré-intemperizado do gnaisse, decorrentes da grande alternância climática entre períodos mais úmidos e mais secos. Normalmente, apresentam textura areno-argilosa a argilo-arenosa.

Situam-se nos topos estreitos e nas pedoformas convexo-convexas, com maior desenvolvimento dos solos localizados nas pendentes (REZENDE, 1971). Com uma localização de maior estabilidade no relevo, possuem uma taxa de pedogênese maior que a taxa de erosão.

Mineralogicamente, apresentam predominância de caulinita, goethita, hematita e traços de gibsita. A maior presença de hematita e a ocorrência intimamente da goethita lhes confere uma tonalidade mais avermelhada, característica da ocorrência desse mineral no perfil (CARDOSO, 1994). Este autor, estudando aspectos geotécnicos ligados à expansibilidade de quatro ocorrências de latossolo da região, encontrou texturas areno-argilosa para três amostras e argilo-arenosa para uma amostra, com limite de liquidez variando de $63 \%$ a $78 \%$ e IP de $20 \%$ a $33 \%$. De acordo com as classificações Unificada (USC) e HBR, todas as amostras enquadraram-se no grupo MH e grupo A-7-5, respectivamente, com índice de grupo variando de 9 a 17.

Segundo Azevedo (1999), no que concerne aos constituintes do Latossolo Vermelho-Amarelo, na amostra no estado natural, foram observadas feições da microestrutura característica dos Latossolos Vermelhos-Amarelos de Viçosa, grãos de esqueleto com microagregação ovóide forte, algo coalecida, com contato face-a-face, em virtude da natureza caulinítica da fração argila destes solos, e pequenos quartzos. O plasma é formado por um conjunto relativamente isotrópico, muito fino, de aspecto floculado, de tonalidades vermelho-amarela e alguns pontos vermelhos escuros. Os vazios são bem visíveis nesta escala e estão compreendidos entre os microagregados e interligados entre si.

Este solo, Figura 3.4, é composto de material completamente intemperizado que é visivelmente uniforme e homogêneo. Esta camada é um solo residual maduro, de acordo com Vargas (1953), e corresponde aos horizontes IA e IB no sistema de 
classificação de Deere \& Patton (1971). Este solo tem experimentado muitos processos pedogenéticos que deram como resultado um latossolo Vermelho-Amarelo e que pode ser identificado como argila areno siltosa.

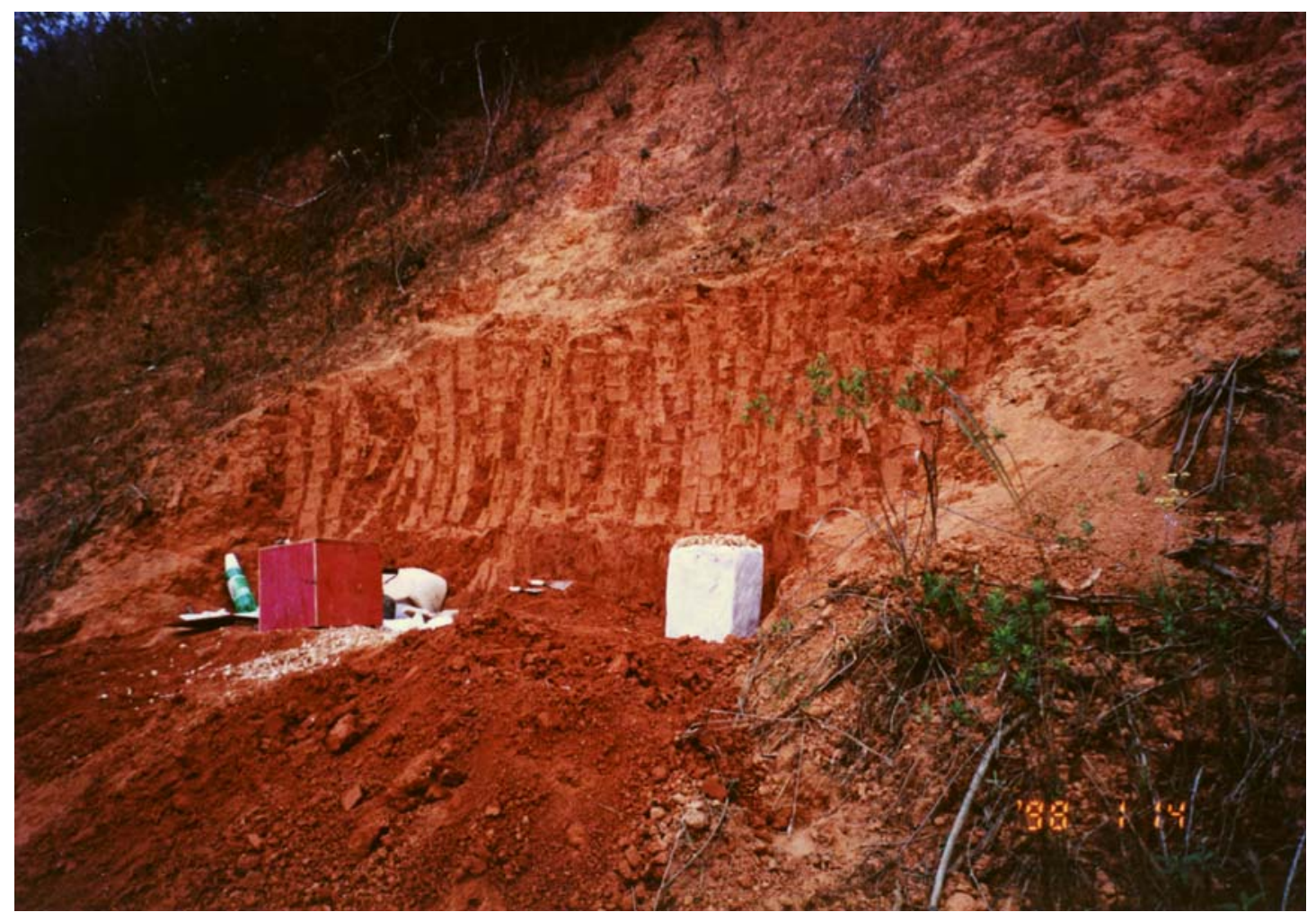

Figura 3.4 - Latossolo Vermelho-Amarelo estudado.

\subsubsection{Solo saprolítico (residual jovem)}

Como já referenciado, além dos solos superficiais, campo de estudo da Pedologia, foi colhida também, uma amostra de solo do manto saprolítico, horizonte C, Figura 3.5. Na sua parte superior, exibe a presença de mica e mostra-se com um tom róseo mais avermelhado, devido à presença de hematita. A textura é areno-siltoargilosa. Na sua parte inferior, apresenta coloração mais acinzentada, com pouca presença de óxidos de ferro, prevalecendo caulinita e mica, textura também areno-siltoargilosa, contudo com maior quantidade de areia fina. 


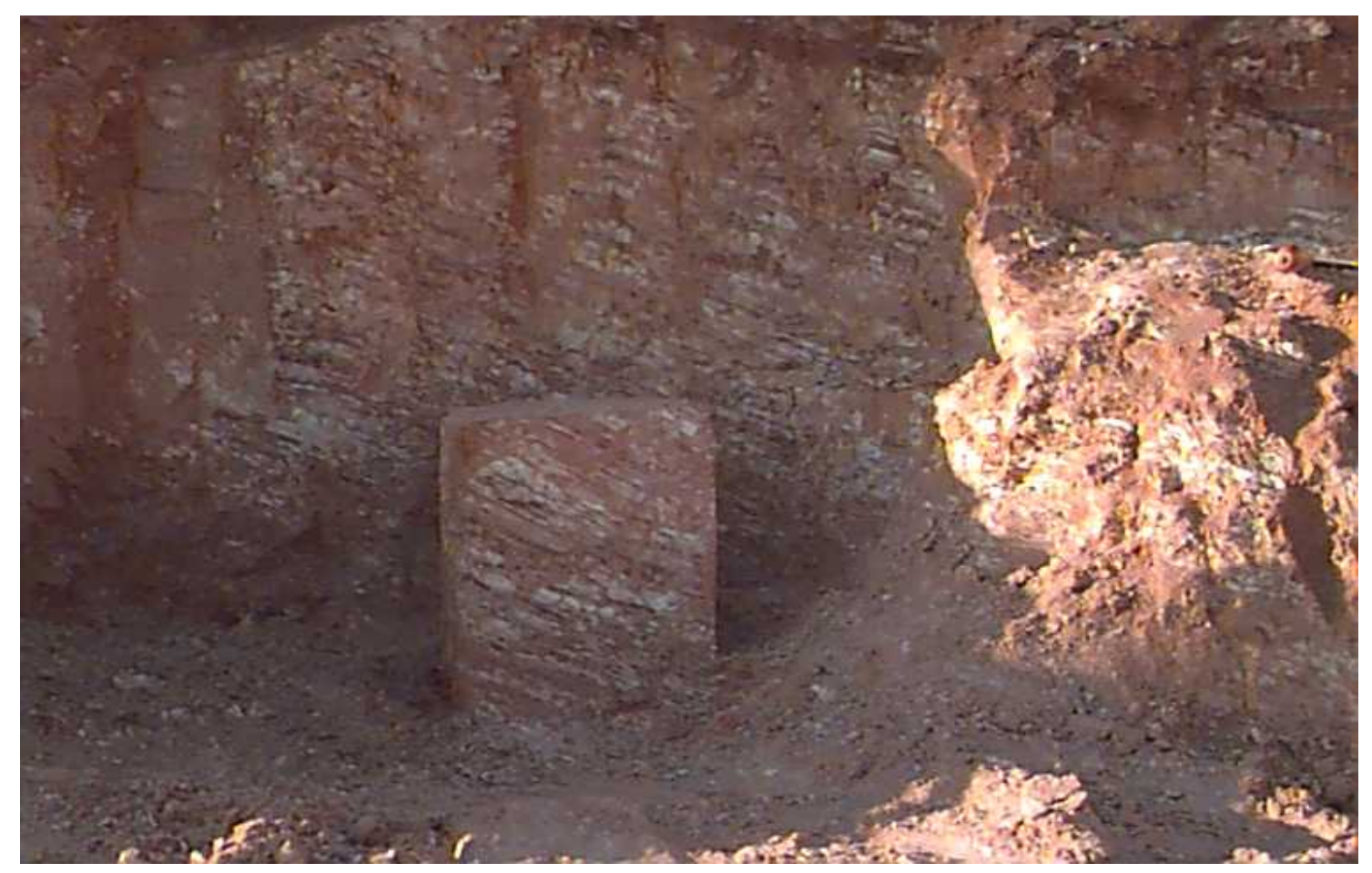

Figura 3.5 - Solo saprolítico estudado.

Esta camada, pode ser classificada como solo residual jovem segundo Vargas (1953) ou como solo saprolítico (horizonte IC) segundo Deere \& Patton (1971). Este solo possui, visualmente, estratificações e características peculiares da rocha mãe que podem ser facilmente identificadas, e que sugerem que o solo seja heterogêneo e anisotrópico. Embora a aparência de rocha seja visível, este solo pode ser facilmente destruído quando manuseado. Trata-se de uma areia siltosa.

\subsection{Métodos}

\subsubsection{Metodologia de campo}

Os trabalhos de campo consistiram de retiradas de amostras indeformadas e deformadas. As amostras indeformadas, representativas do solo quanto à estrutura, umidade, constituição mineralógica e textura, foram obtidas em blocos com dimensões de $35 \mathrm{~cm} \mathrm{x} 35 \mathrm{~cm}$ x $35 \mathrm{~cm}$. As amostras deformadas, representativas do solo quanto à textura e constituição mineralógica, foram retiradas com o emprego de pá, picareta, enxada. As amostras foram armazenadas em sacos plásticos e transportadas para o laboratório. 


\subsubsection{Metodologia de laboratório}

O programa experimental consistiu de ensaios para a caracterização: granulometria, massa específica dos sólidos, limites, curva característica, Mini-MCV e Perda de Massa por Imersão destinados à caracterização MCT, Difração Raio X destinado à caracterização mineralógica e ensaios destinados à análise porosimétrica e micromorfológica. Foram executados também ensaios triaxiais de compressão axial e hidrostática.

\subsubsection{Ensaios de caracterização}

\subsection{Caracterização Geotécnica}

Para os dois solos foram realizados ensaios de granulometria conjunta (NBR 7181/ABNT-1984), ensaios de limite de liquidez (NBR6459/ABNT-1984) e de plasticidade (NBR7180/ABNT-1984) e ensaios de massa específica dos sólidos (NBR6508/ABNT-1984).

Ensaios para determinação da curva característica foram realizados nos dois solos utilizando-se a câmara de Richards. Neste equipamento a sucção é aplicada elevando-se a pressão de ar e mantendo-se a pressão de água igual à atmosférica. A sucção corresponde portanto à pressão de ar, visto que a pressão na água é zero. Os valores de sucção aplicados com o uso do equipamento foram de 25, 50, 100, 150, 200, 250, 300 e $350 \mathrm{kPa}$. O tempo para estabilização do peso das amostras variou de uma a duas semanas. Os corpos de prova foram obtidos utilizando-se anéis biselados com diâmetro interno de aproximadamente $75 \mathrm{~mm}$ e altura de $20 \mathrm{~mm}$.

\subsection{Análise Mineralógica}

As análises mineralógicas foram realizadas no laboratório de solos da Universidade Federal de Viçosa. Estas análises foram realizadas na fração AreiaGrossa, Areia-Fina e Argila. Para os ensaios na fração areia as lâminas foram do tipo escavada (não orientada), montadas com o pó destas frações. As lâminas da fração argila foram montadas pelo método do esfregaço (lâminas orientadas), as quais foram colocadas para secar à temperatura ambiente. Os componentes destas frações foram identificados por difração de raios $\mathrm{X}$, utilizando-se tubo de cobalto com monocromador de grafite curvo, varrendo-se as amostras entre $4^{0}$ e $50^{0} 2 \theta$. 


\subsection{Caracterização MCT (Miniatura, Compactado, Tropical)}

Os ensaios necessários para obter a classificação MCT são: Mini-MCV e Perda de Massa por Imersão. Estes ensaios foram realizados segundo o procedimento introduzido por NOGAMI e VILLIBOR (1981).

\subsection{Análise Porosimétrica}

A análise porosimétrica foi realizada no Instituto de Física de São Carlos - USP utilizando-se o “POROSIZER 9310”, da Micromeritics Instrument Corporation, com capacidade máxima de 30000 psi e com controle automático de pressão.

Os ensaios de porosimetria por intrusão de mercúrio foram realizados, nos dois horizontes, através de amostras, indeformadas e cúbicas, com aproximadamente $1,5 \mathrm{~cm}$ de lado. Neste ensaio, a amostra de solo, previamente seca, é submetida à injeção de mercúrio sob pressão. Inicialmente a amostra de solo é colocada em um recipiente, designado de penetrômetro, o qual é preenchido por mercúrio. Em seguida, aplica-se o vácuo para que o mercúrio possa penetrar nos poros do solo sem a interferência da água e do ar. Para cada estágio de pressão aplicada, mede-se o volume de mercúrio que penetra nos poros da amostra. O ensaio começa com a intrusão nos poros de maior diâmetro, a baixas pressões, estendendo-se a intrusão para os poros de menor diâmetro, à medida que as pressões vão sendo elevadas.

\subsection{Análise Micromorfológica}

As análises foram realizadas em amostras indeformadas, no laboratório de solos da Universidade Federal de Viçosa. O preparo e a descrição de seções finas dos solos obedeceu aos critérios de Murphy (1986).

Em laboratório os corpos de prova foram colocados em estufa a $35^{0} \mathrm{C}$, por dois dias, seguindo a saturação com acetona (imersão total da amostra em bacia plástica), para remover a umidade remanescente e favorecer a penetração da resina. Procedeu-se à impregnação dos corpos de prova com uma resina crística e estireno como diluente, adicionada de pigmento UV fluorescente. A impregnação foi feita através de vácuo e a cura foi feita em ambiente ventilado, por sete dias. Após a polimerização, foram preparadas seções finas para observação em microscópio petrográfico, revelando a 
microestrutura dos solos. As lâminas foram montadas por meio de araldite e desbastadas até atingir aproximadamente 30 micrômetros.

As fotomicrografias foram tiradas em microscópio petrográfico Carl Zeiss, entre luz plana, de seções finas obtidas das amostras dos dois solos.

\subsubsection{Ensaios triaxiais}

\subsection{Ensaios em amostras saturadas}

Para a realização dos ensaios de compressão triaxial foi utilizado o equipamento mostrado na Figura 3.6. As pressões foram aplicadas e controladas por atuadores de pressão/volume. Todas as medidas foram realizadas de forma automatizada externamente à câmara. Inicialmente foi feita uma comparação entre medidas de variação volumétrica realizadas com base na quantidade de água entrando ou saindo da câmara triaxial, levando-se em conta a curva de calibração da câmara triaxial e o volume deslocado pela entrada do pistão da câmara durante a fase de cisalhamento, e medidas de variação volumétrica pela água que sai de dentro do corpo de prova. Verificou-se que para a câmara utilizada e para o tempo de ensaio, as relações entre a deformação axial versus deformação volumétrica foram equivalentes, demonstrando assim, que para a câmara utilizada, pequena e cintada, o efeito de dilatação durante a ruptura é insignificante. O deslocamento axial no topo da amostra foi obtido por meio de um transdutor de deslocamento, do tipo resistivo, instalado na base do anel dinamométrico. O valor da contra pressão foi obtido por meio de um transdutor de pressão instalado de modo a medir a pressão neutra na base do corpo de prova. A diferença de tensões principais foi obtida por intermédio de um transdutor de deslocamento acoplado a um anel dinamométrico.

Ensaios de compressão triaxial convencionais drenados em amostras saturadas por contra-pressão foram realizados em três direções diferentes. A primeira corresponde à direção vertical, considerando a posição do bloco em campo. As duas outras correspondem às direções paralela e perpendicular ao bandamento do solo residual jovem de gnaisse, conforme apresentado na Figura 3.7. No solo residual maduro, por não apresentar nenhuma foliação visível, os ensaios foram realizados na direção vertical (campo), perpendicular à direção vertical e a $45^{0}$ em relação à direção vertical. Os ensaios foram carregados em compressão axial e as tensões de adensamento variaram entre 50 e $400 \mathrm{kPa}$. Adicionalmente realizaram-se ensaios de compressão hidrostática 
drenados para amostras do solo residual jovem e maduro. Nesta fase, para o solo maduro realizaram-se 14 ensaios e para o solo jovem, 18 ensaios.

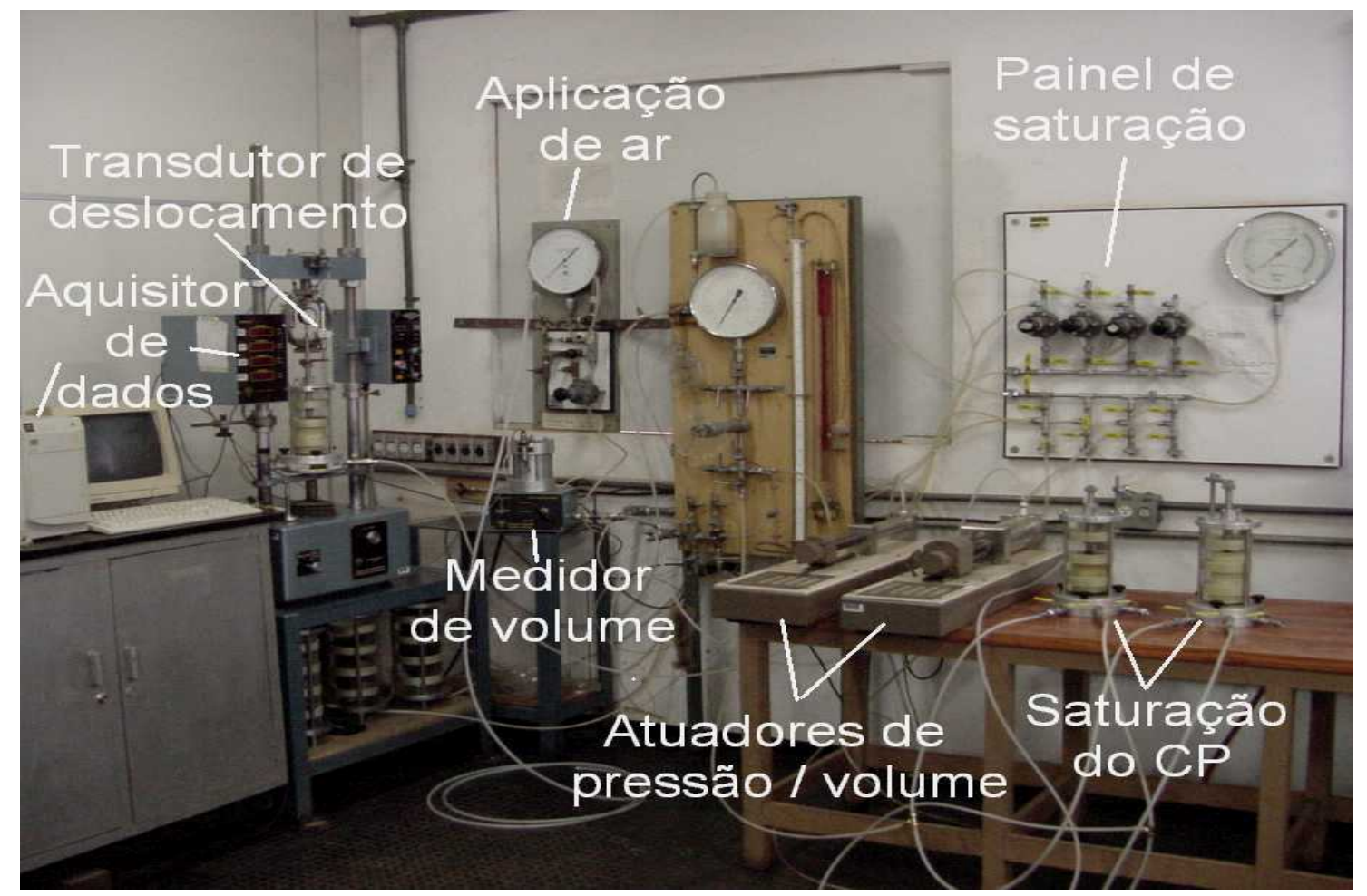

Figura 3.6 - Equipamento triaxial convencional utilizado para os ensaios saturados.

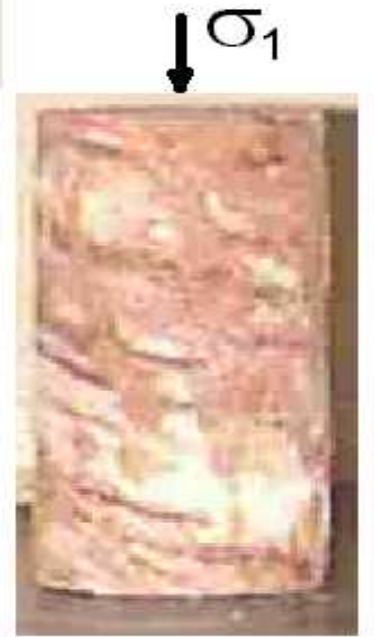

Vertical

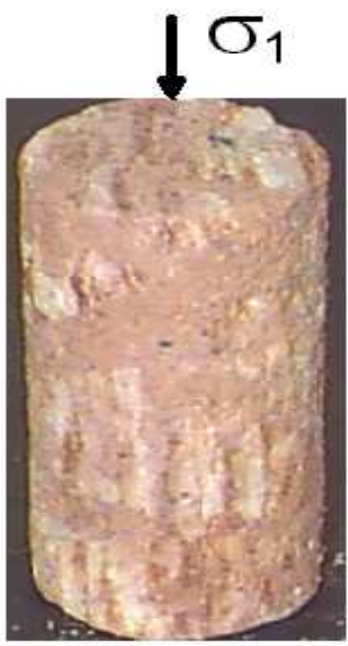

Paralela

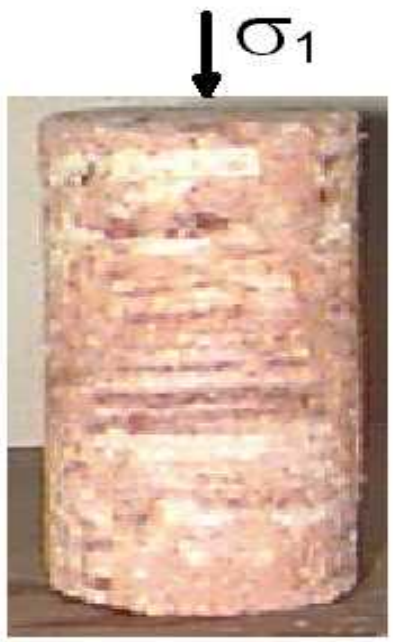

Perpendicular

Figura 3.7 - Direções adotadas, em relação ao bandamento, na moldagem dos corpos de prova para o solo residual jovem. 
Foram realizados ainda, ensaios de tensão controlada, em trajetórias diferentes da convencional, no solo jovem, em uma prensa do tipo Bishop Wesley. Fazem parte deste equipamento os seguintes componentes: uma prensa triaxial do tipo Bishop Wesley, três atuadores de pressão, três transdutores internos de deslocamento do tipo efeito Hall (dois axiais e um radial), uma célula de carga submergível, uma interface para comunicação micro-atuadores-transdutores e um software de gerenciamento do sistema, denominado GDSTTSV7.18. Na Figura 3.8 é apresentada a disposição geral dos equipamentos para a realização dos ensaios com a prensa triaxial do tipo Bishop Wesley, na Figura 3.9 são apresentados os transdutores de deslocamento do tipo efeito Hall e na Figura 3.10 é apresentado um esquema da prensa com suas principais conexões com os atuadores de pressão/volume e as principais medidas efetuadas durante os ensaios.

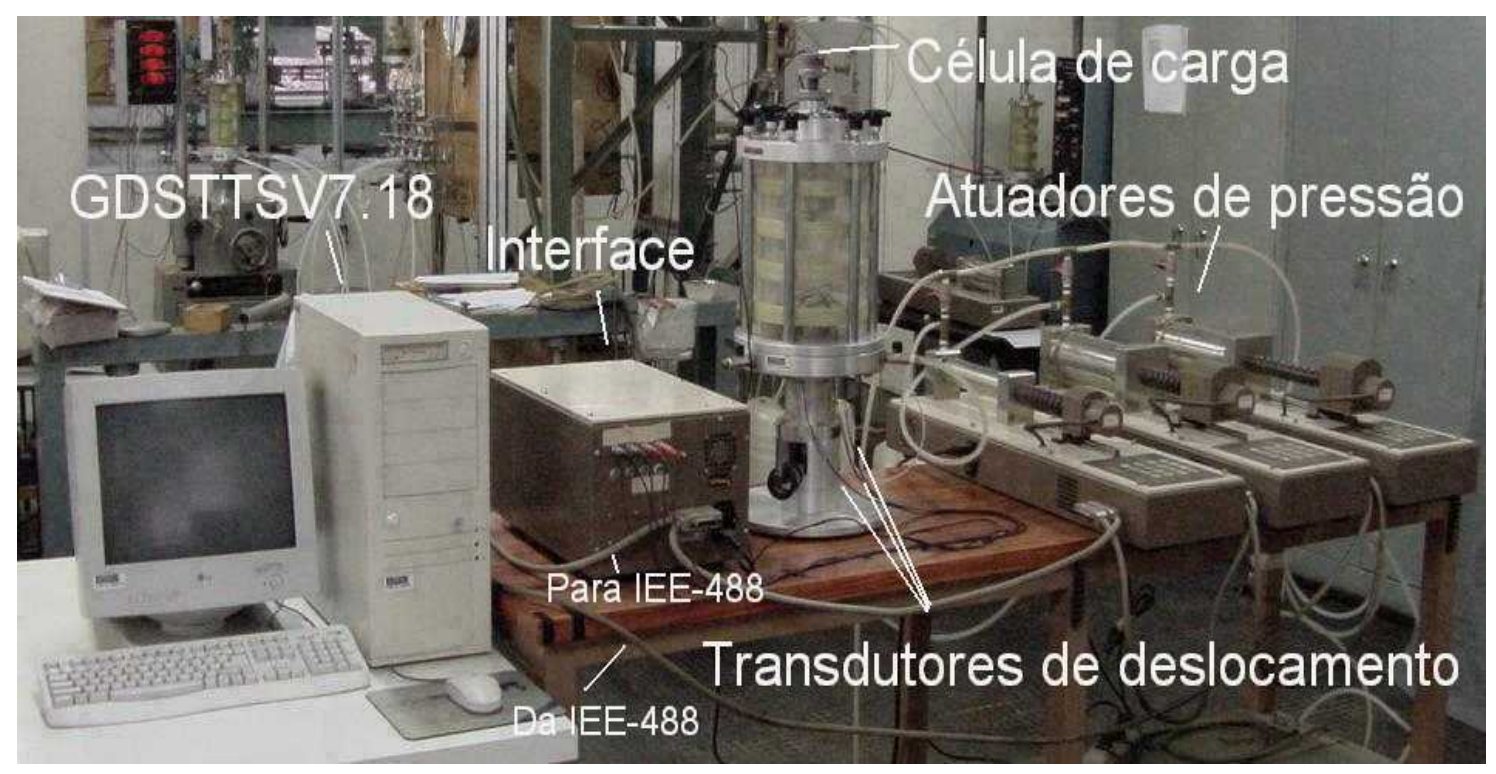

Figura 3.8 - Disposição geral dos componentes da prensa triaxial do tipo Bishop Wesley servo contralada. 


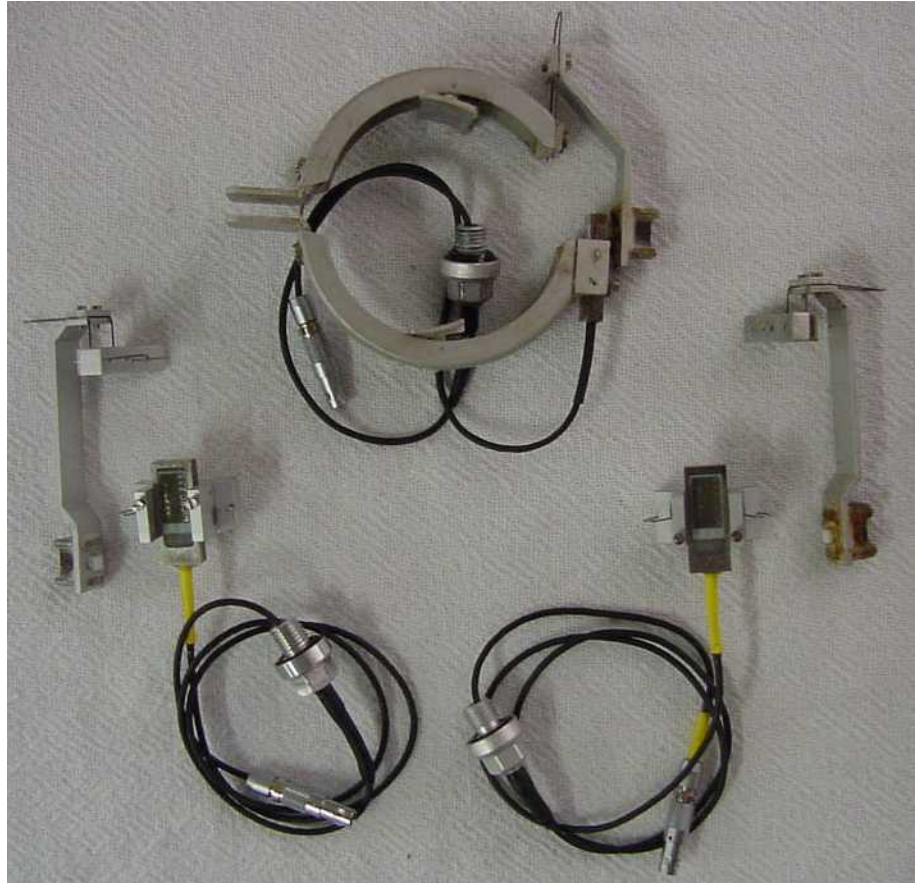

(a)

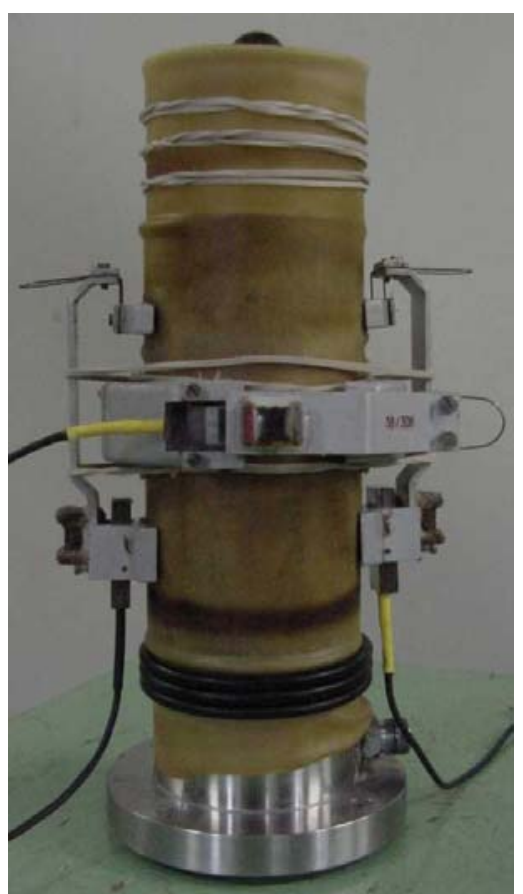

(b)

Figura 3.9 - Transdutores de deslocamento de efeito Hall: a)Desmontados; b)Montados sobre o corpo de prova.

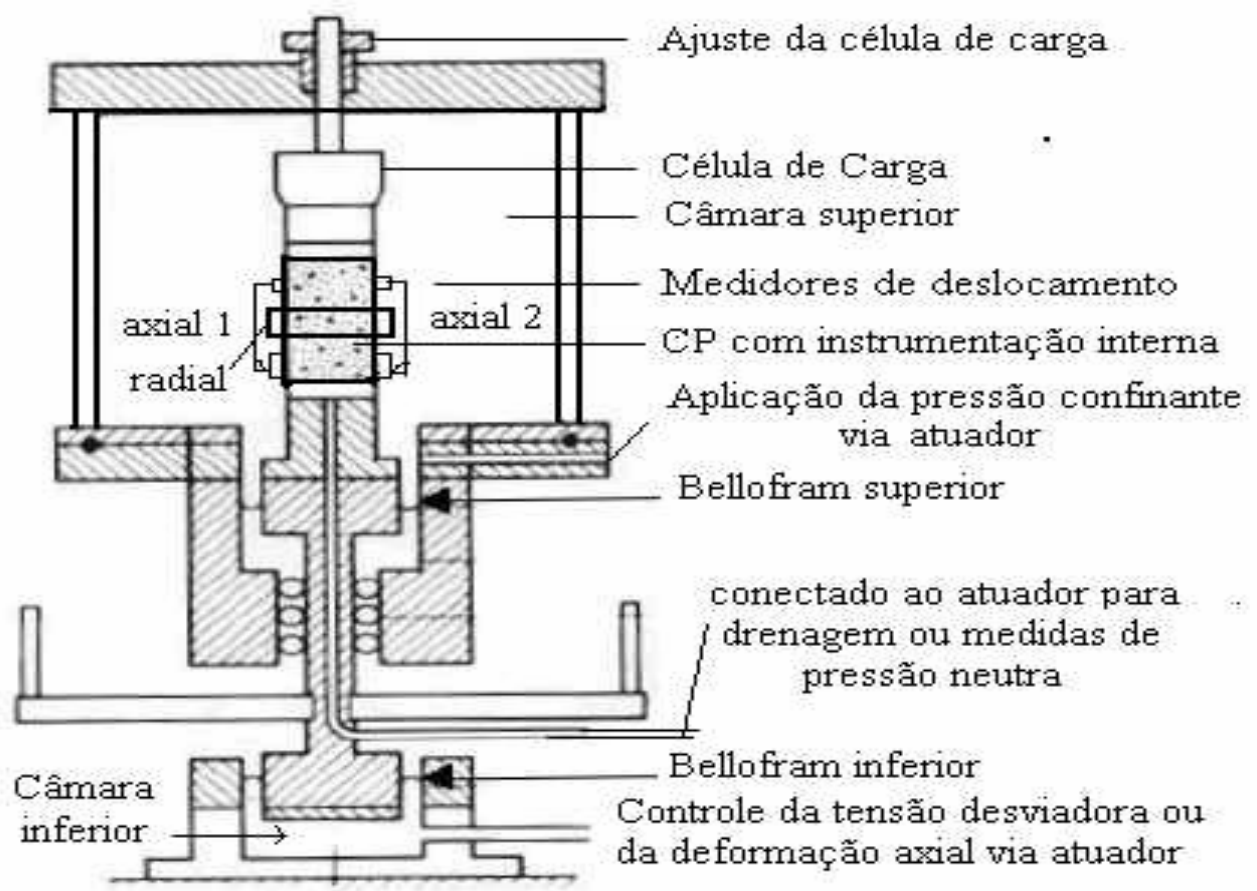

Figura 3.10 - Representação esquemática da prensa Bishop Wesley utilizada. 
Para a realização dos ensaios, os corpos de prova eram colocados na base da câmara, após o que se instalava a membrana de látex e o cabeçote para a aplicação da tensão desviadora. Feito isto instalava-se os medidores de deslocamento internos. A instalação dos medidores de deslocamento internos se deu por colagem das suas bases com silicone na membrana de látex que revestia a amostra. Estando o silicone vulcanizado, a posição relativa do imã/sensor de efeito hall era ajustada de modo a que todo o intervalo de leitura dos transdutores fosse utilizado. Devidamente instalados os transdutores de deslocamento internos, era colocada a parte superior da prensa, que contém a célula de carga, e assim era feito o ajuste desta célula que era deslocada no sentido vertical até que tocasse levemente o corpo de prova. Procedia-se então ao enchimento da câmara utilizando-se água destilada e deaerada.

Nesses ensaios os corpos de prova foram primeiramente saturados utilizando-se a técnica de saturação por contra pressão e, logo em seguida, adensados com uma tensão de $150 \mathrm{kPa}$, um pouco maior que metade da tensão de pré-adensamento hidrostática, e consecutivamente cisalhados segundo as trajetórias indicadas na Figura 3.11, utilizandose o aplicativo para controle dos atuadores e medidas de instrumentação interna, “GDSTTSV7.18”. Todos os ensaios foram realizados de modo que, a partir de uma previsão inicial dos pontos de ruptura do corpo de prova, as velocidades de aplicação de tensões fossem tais que os ensaios tivessem uma duração mínima de oito horas. Para valores maiores de deformação, quando a capacidade de medida dos trandutores de deslocamento internos do tipo efeito Hall era superada, utilizaram-se as medidas realizadas externamente por meio dos atuadores para calcular os acréscimos de deformação do corpo de prova.

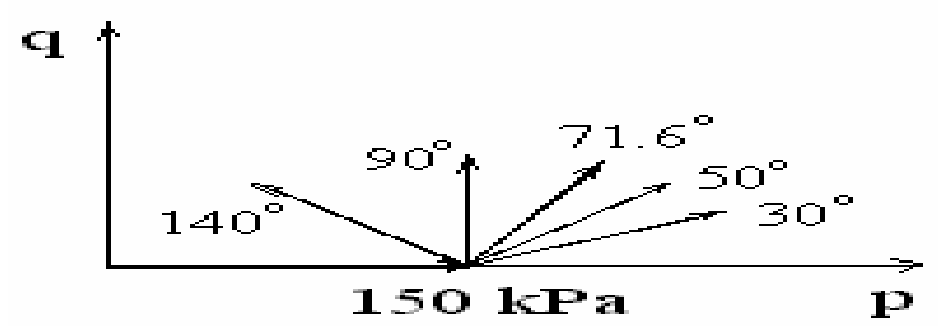

Figura 3.11 - Trajetórias de tensões adotadas nos ensaios com tensão controlada realizados na célula do tipo Bishp Wesley.

Os ANEXOS de 1 até 4 mostram as dimensões e características de todos os corpos de prova dos dois horizontes, utilizados nos ensaios triaxiais saturados por contra pressão. 


\subsection{Ensaios em amostras não saturadas}

Os ensaios em amostras não saturadas consistiram de ensaios onde a sucção matricial $\left(\mathrm{u}_{\mathrm{a}}-\mathrm{u}_{\mathrm{w}}\right)$ era instalada e controlada e ensaios em corpos de prova secos ao ar, onde a sucção não era controlada durante o ensaio.

Os ensaios com controle da sucção matricial $\left(\mathrm{u}_{\mathrm{a}}-\mathrm{u}_{\mathrm{w}}\right)$ compreenderam ensaios de compressão triaxial e compressão hidrostática, realizados na câmara do tipo Bishop Wesley . O objetivo dos ensaios triaxiais de compressão axial com controle de sucção, realizados na Bishop Wesley, nos solos maduro e jovem, foi obter as envoltórias de resistências dos solos em diferentes sucções e profundidades, e juntamente com ensaios de compressão hidrostática, com sucção controlada, as curvas de escoamento em diferentes níveis de sucção, mostrando assim como é o encruamento do solo com o aumento da sucção.

Para que os ensaios triaxiais fossem realizados em um menor tempo, a sucção matricial desejada foi imposta aos corpos de prova em câmaras separadas (Figura 3.12), conectadas a um painel de ar comprimido, utilizando-se a técnica de translação de eixos (Hilf, 1956). O período mínimo de permanência dos corpos de prova para instalação da sucção foi determinado através da observação da constância de peso das amostras, que foi em torno de 12 dias para os dois solos ensaiados. Para que todos os corpos de prova seguissem trajetórias prévias de sucção, aproximadamente iguais, estes eram umedecidos até valores de umidade próximos da umidade de saturação, para que depois a sucção fosse aplicada.

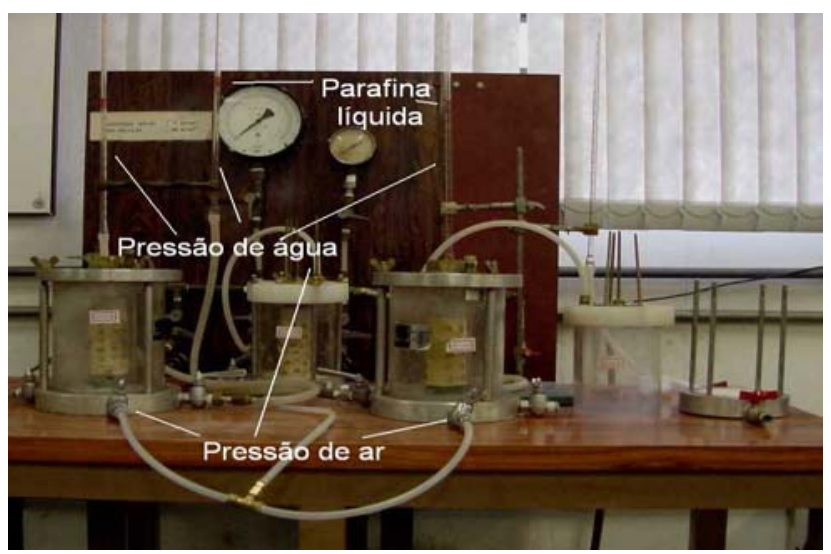

Figura 3.12 - Câmaras para instalação da sucção matricial nos ensaios com sucção controlada.

Após o período de instalação da sucção matricial nas amostras, estas eram levadas à câmara triaxial para o adensamento e o cisalhamento. Procurando-se corrigir 
eventuais variações na sucção matricial instalada no corpo de prova durante a montagem na câmara triaxial, o corpo de prova era deixado na mesma por um período de um a dois dias, observando-se a quantidade de água expulsa ou absorvida pelo corpo de prova após sua instalação. Em todos os ensaios utilizou-se a pressão de água igual a pressão atmosférica na base do CP . Para a realização dos ensaios, a base da câmara da prensa triaxial Bishop Wesley foi trocada por outra contendo uma pedra porosa de alto valor de entrada de ar (5 Bar), de 50mm de diâmetro. A aplicação da sucção matricial desejada se deu por uso da técnica de translação de eixos, sendo a pressão de ar aplicada pelo topo da amostra através de um compressor de ar comprimido, e controlada por uma válvula de pressão ligada a um manômetro. Durante a fase de repouso do corpo de prova na câmara triaxial, o valor da tensão confinante foi mantida sempre $10 \mathrm{kPa}$ superior à pressão de $\operatorname{ar}\left(\sigma_{\mathrm{c}}-\mathrm{u}_{\mathrm{a}}=10 \mathrm{kPa}\right)$. O cisalhamento foi feito utilizando a opção de deformação controlada, existente no programa, permitindo assim obter o comportamento pós pico dos solos ensaiados. A velocidade adotada nos ensaios foi de $0.006 \mathrm{~mm} /$ minuto. Como a amostra se apresentava não saturada, as medidas de deformação volumétrica efetuadas pelo atuador conectado à base do corpo de prova não foram possíveis. Deste modo, o cálculo das deformações sofridas pela amostra só pôde ser feito até o intervalo de medida útil dos transdutores de deslocamentos internos. Os valores de sucção matricial escolhidos para a realização dos ensaios foram de 40, 80, 160 e $320 \mathrm{kPa}$ e os valores de $\left(\sigma_{\mathrm{c}}-\mathrm{u}_{\mathrm{a}}\right)$ adotados foram de 50, 100 e $200 \mathrm{kPa}$. No solo jovem foram realizados 14 ensaios, sendo 11 de cisalhamento triaxial e 3 de compressão hidrostática e no solo maduro foram realizados 8 ensaios de cisalhamento triaxial e três de compressão hidrostática.

Os ensaios em corpos de prova secos ao ar e posteriormente cisalhados sem o controle da sucção matricial tiveram dois objetivos. O primeiro foi checar os ensaios com controle de sucção realizados, baseando-se no fato que a tensão máxima obtida nos ensaios com as amostras secas ao ar (sucção bem alta) deve ser maior que a tensão máxima obtida nos ensaios com sucção controlada realizados. O segundo objetivo foi tentar prever, juntamente com ensaios triaxiais saturados $\left(\mathrm{u}_{\mathrm{a}}-\mathrm{u}_{\mathrm{w}}=0\right)$, a curva coesão versus sucção matricial fornecida pelos ensaios com sucção controlada.

Os ANEXOS de 5 até 6 mostram as dimensões e características dos corpos de prova dos dois horizontes, utilizados nos ensaios triaxiais com sucção matricial controlada. O ANEXO 7 mostra as características dos corpos de prova do solo residual jovem, secos ao ar e submetidos aos ensaios triaxiais sem o controle de sucção. 


\section{RESULTADOS}

\subsection{Ensaios de Caracterização}

\subsubsection{Caracterização Geotécnica}

Na Figura 4.1 mostram-se as curvas granulométricas, do solo residual maduro e do solo residual jovem, obtidas através do ensaio de granulometria conjunta. Na Tabela 4.1 mostram-se os resultados dos ensaios de limite de liquides, limite de plasticidade, e de massa específica dos sólidos.

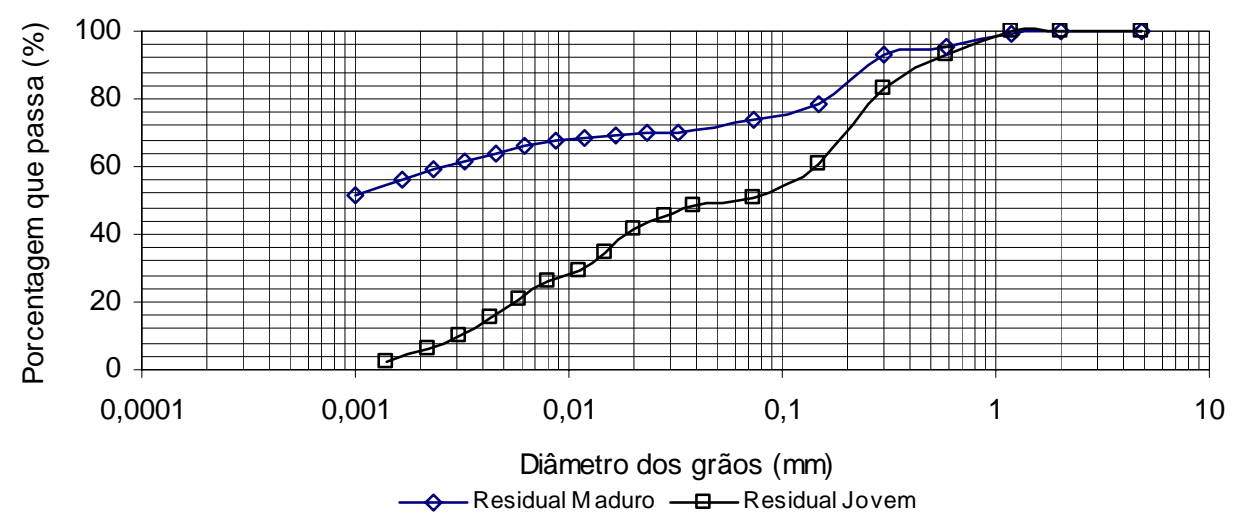

Figura 4.1 - Curvas granulométricas dos solos estudados.

Tabela 4.1 - Resultados dos ensaios de caracterização geotécnica realizados.

\begin{tabular}{|c|c|c|c|c|c|c|c|c|c|}
\hline \multirow[t]{2}{*}{ Horizonte } & \multicolumn{3}{|c|}{$\begin{array}{r}\text { Areia } \\
(\%)\end{array}$} & $\begin{array}{l}\text { Silte } \\
(\%)\end{array}$ & $\begin{array}{c}\text { Argila } \\
\text { (\%) }\end{array}$ & $\begin{array}{l}\text { LL } \\
\text { (\%) }\end{array}$ & $\begin{array}{c}\text { LP } \\
(\%)\end{array}$ & IP & $\begin{array}{c}\gamma_{\mathrm{s}} \\
\left(\mathrm{kN} / \mathrm{m}^{3}\right)\end{array}$ \\
\hline & Grossa & Média & Fina & & & & & & \\
\hline Maduro & 5 & 11 & 11 & 15 & 58 & 68 & 39 & 29 & 27,2 \\
\hline Jovem & 6 & 24 & 20 & 45 & 5 & 38 & 23 & 15 & 26,7 \\
\hline
\end{tabular}

Quanto ao sistema Unificado de Classificação de Solos (SUCS) o solo maduro é classificado como MH e o solo jovem como SC-SM. Quanto a Classificação do Highway Research Board (HRB) o solo maduro é classificado como A-7-5 (19) e o solo jovem como A-6(5). 


\subsubsection{Ensaios de Caracterização Mineralógica}

Na Figura 4.2 mostra-se o resultado da caracterização mineralógica, por difração de raio $\mathrm{X}$, realizada no solo maduro para as frações areia grossa, areia fina e argila. $\mathrm{Na}$ Figura 4.3 mostra-se o difratograma expandido da fração argila, onde se pode apreciar com mais detalhe os minerais presentes nesta fração.

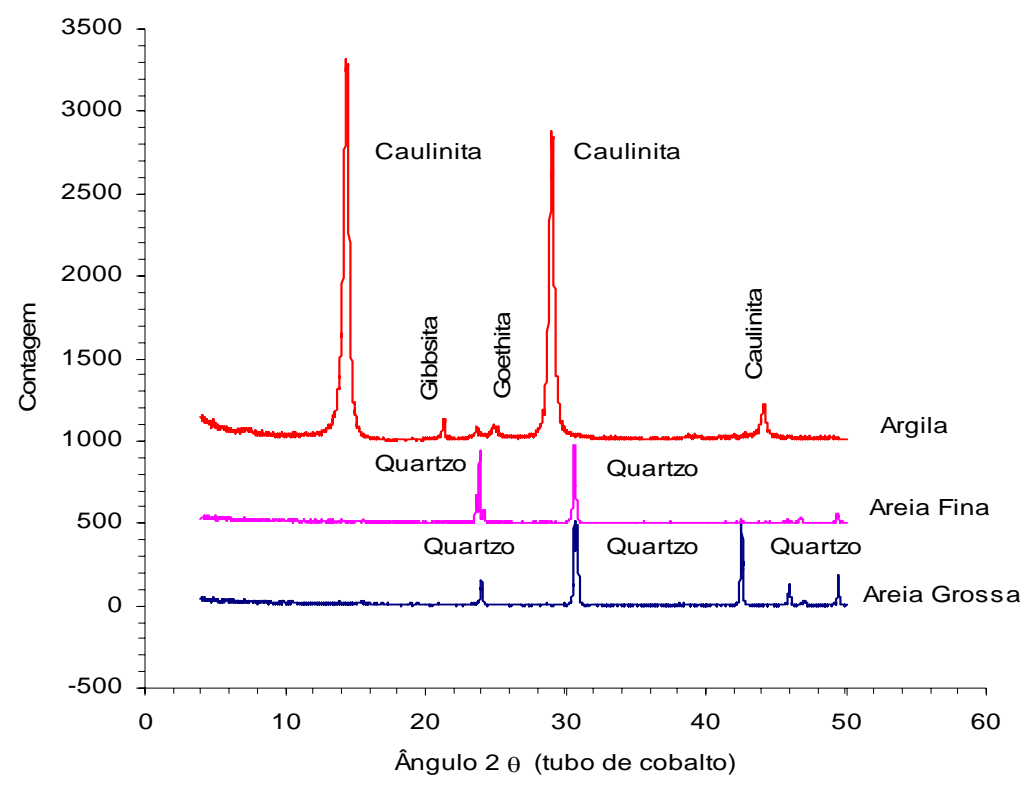

Figura 4.2 - Difratogramas do solo residual maduro.

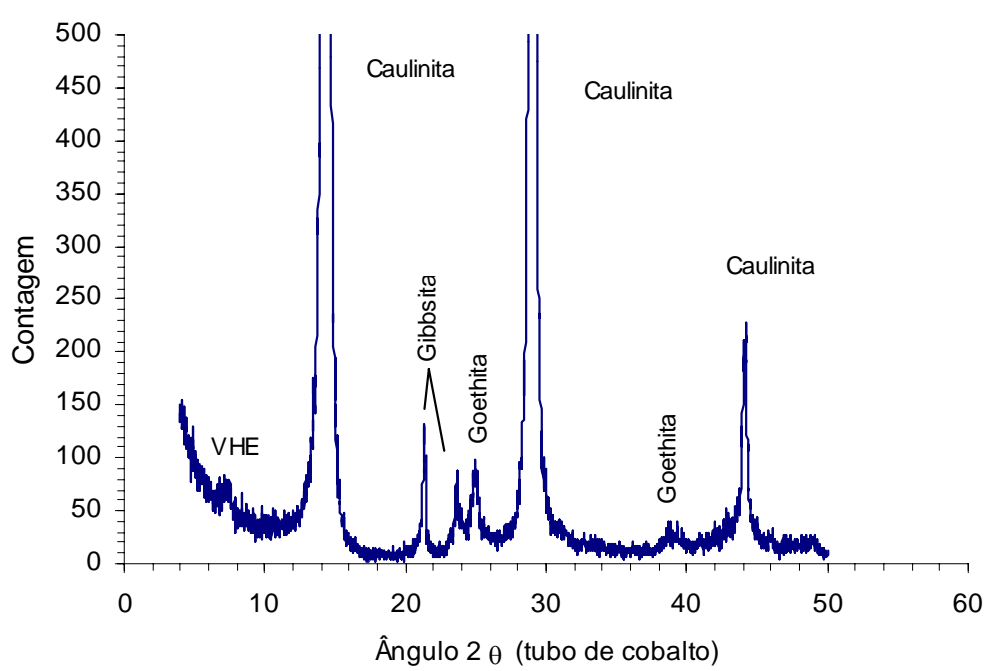

Figura 4.3 - Difratograma expandido da fração argila do solo maduro. 
Na Figura 4.4 mostra-se o resultado da caracterização mineralógica, por difração de raio $\mathrm{X}$, realizada no solo jovem para as frações areia grossa, areia fina e argila. Na Figura 4.5 mostra-se o difratograma expandido da fração argila.

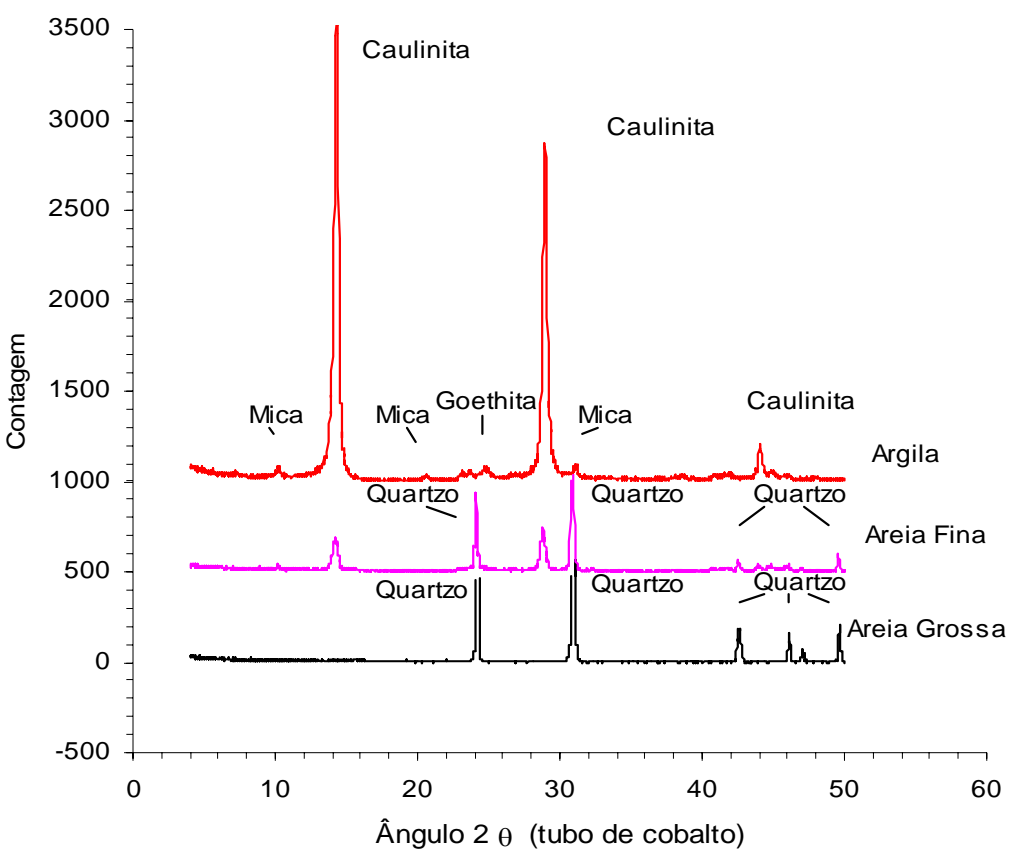

Figura 4.4 - Difratogramas do solo residual jovem.

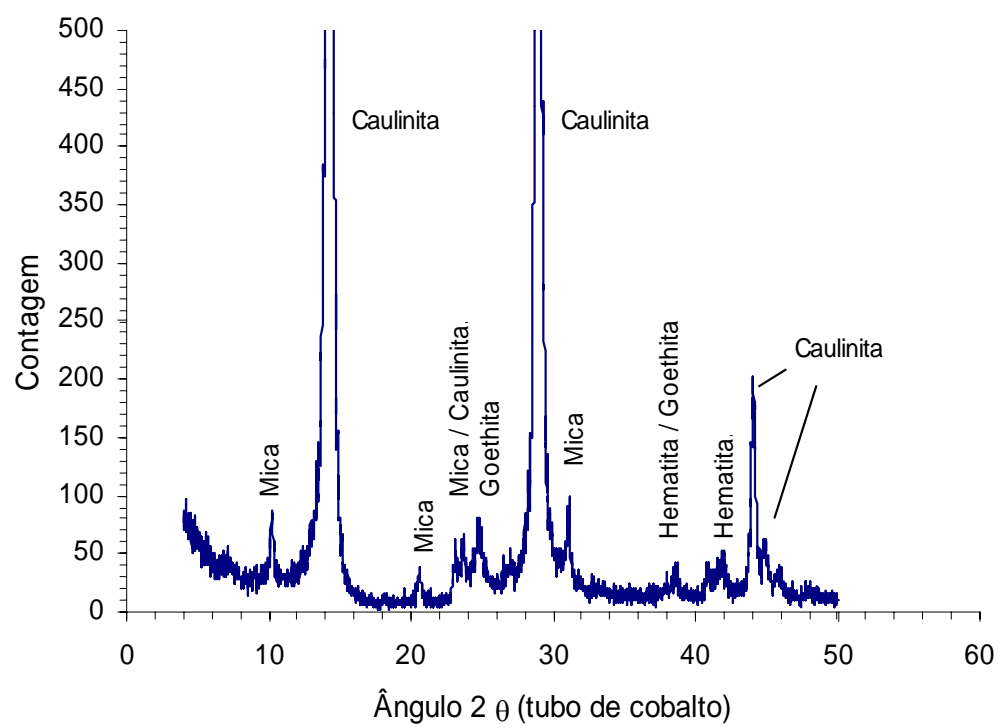

Figura 4.5 - Difratograma expandido da fração argila do solo jovem. 


\subsubsection{Ensaios de porosimetria}

Nas Figuras 4.6 a 4.8 mostram-se os resultados do ensaio de porosimetria por intrusão de mercúrio realizado em duas amostras do solo maduro. Na Figura 4.6 mostrase a curva pressão de mercúrio aplicada (Psi) versus volume da intrusão (carga e descarga), na Figura 4.7 mostra-se a curva diâmetro dos poros (micrometro) versus volume da intrusão e na Figura 4.8 mostra-se a curva diâmetro dos poros (micrometro) versus log do diferencial de volume.

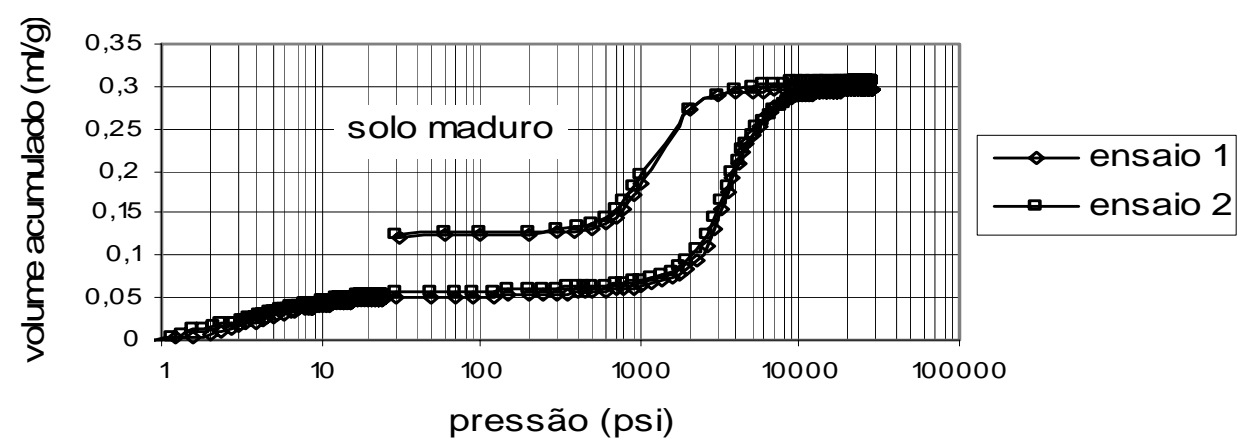

Figura 4.6 - Pressão de mercúrio (psi) versus volume acumulado de mercúrio (ml/g), (solo maduro).

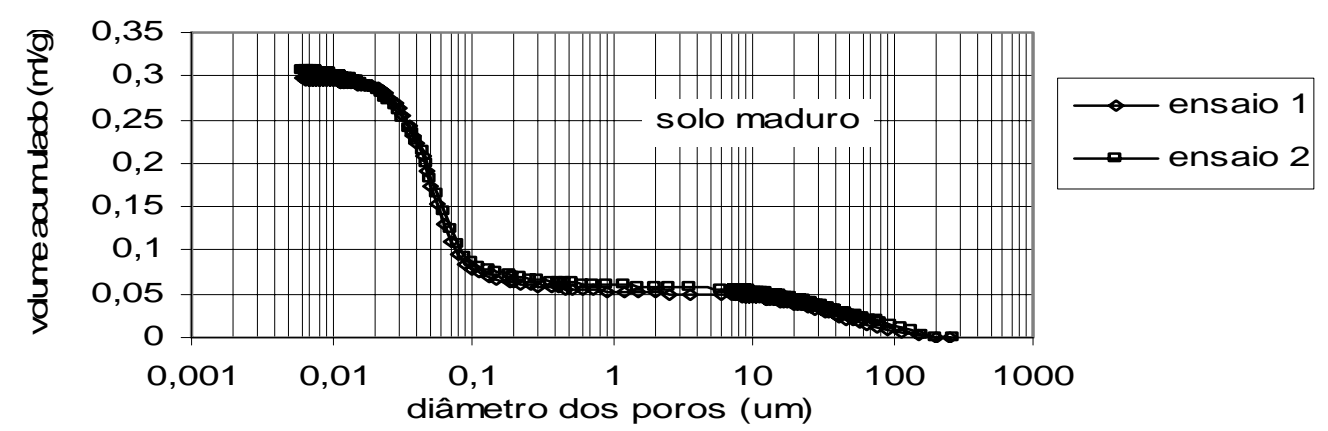

Figura 4.7 - Diâmetro dos poros (micrometro) versus volume acumulado de mercúrio (ml/g), (solo maduro).

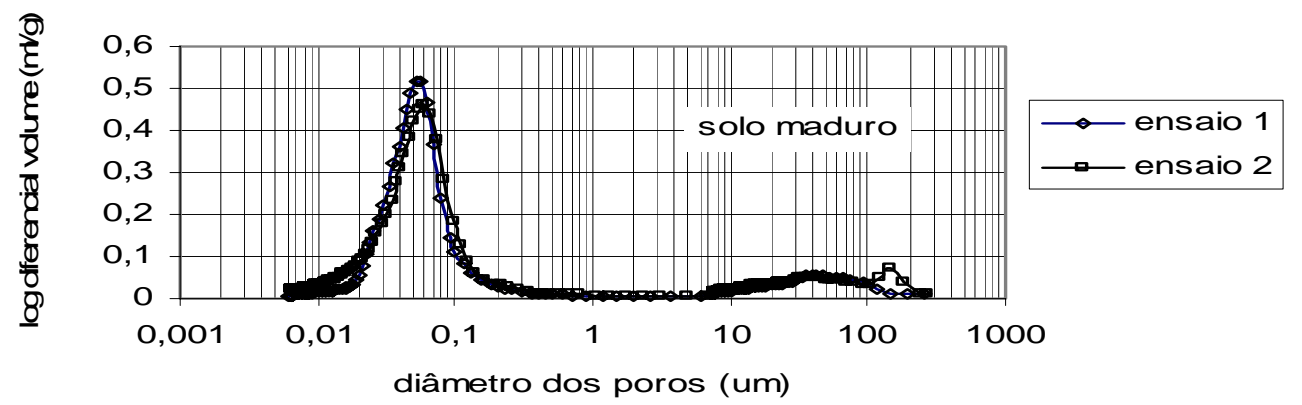

Figura 4.8 - Diâmetro dos poros versus log diferencial do volume de mercúrio (ml/g), (solo maduro). 
Nas Figuras 4.9 a 4.11 mostram-se os resultados para duas amostras do solo jovem. Na Figura 4.9 mostra-se a curva pressão de mercúrio versus volume da intrusão (carga e descarga), na Figura 4.10 mostra-se a curva diâmetro dos poros (micrometro) versus volume da intrusão e na Figura 4.11 mostra-se a curva diâmetro dos poros (micrometro) versus log do diferencial do volume.

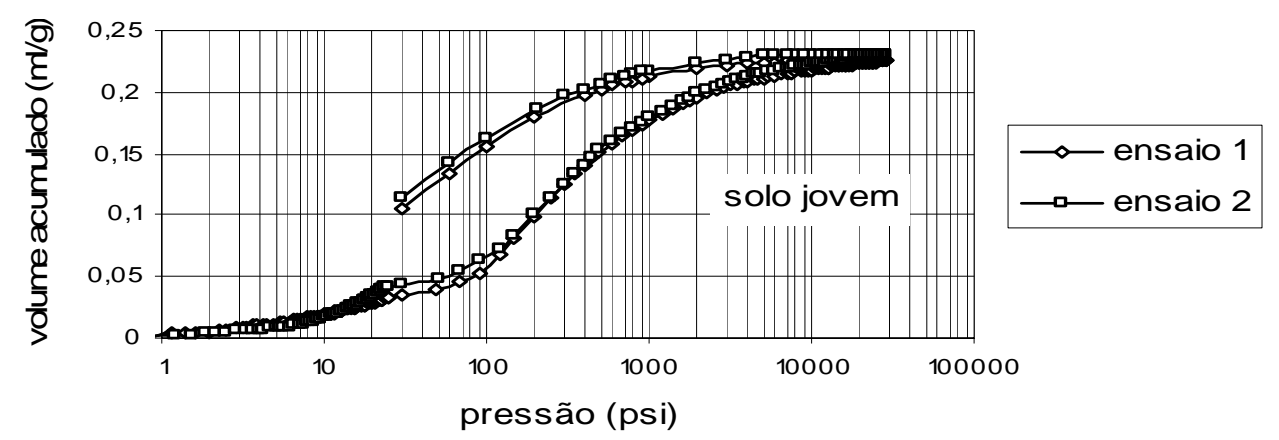

Figura 4.9 - Pressão de mercúrio (Psi) versus volume acumulado de mercúrio (ml/g), (solo jovem).

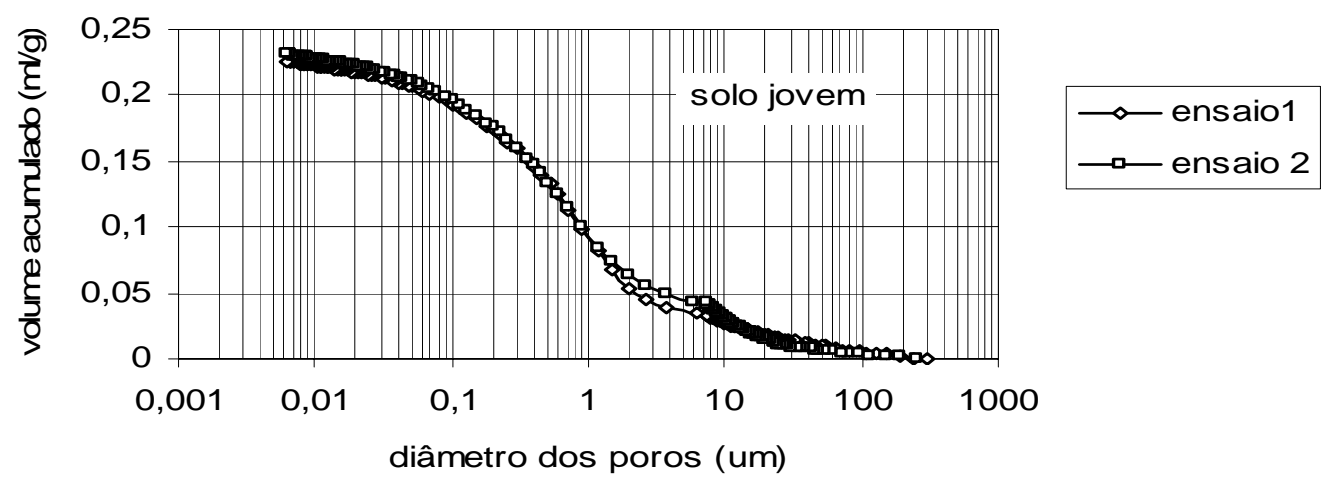

Figura 4.10 - Diâmetro dos poros (micrometro) versus volume acumulado de mercúrio (ml/g), (solo jovem).

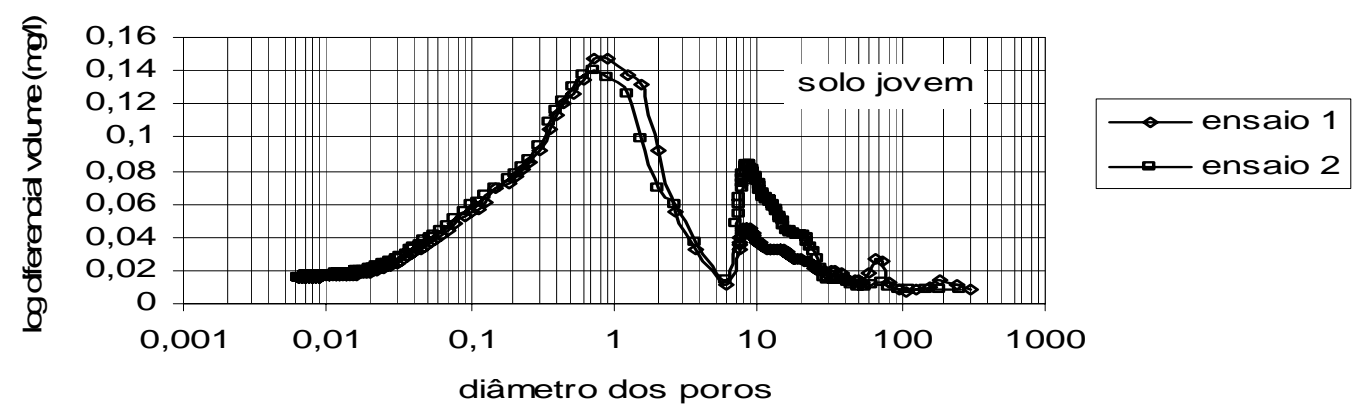

Figura 4.11 - Diâmetro dos poros versus log diferencial do volume de mercúrio (ml/g) (solo jovem). 


\subsubsection{Classificação MCT}

Nas Figuras 4.12 e 4.13 mostram-se os resultados obtidos para o solo maduro no ensaio Mini MCV e na Figura 4.14 mostra-se o resultado do ensaio de perda de massa por imersão.

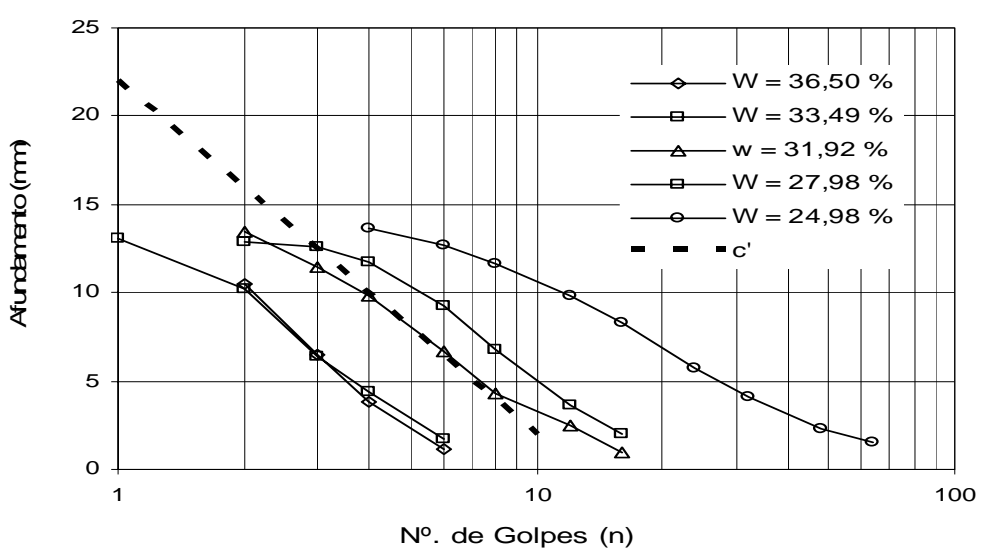

Figura 4.12 - Curvas de Afundamento (mm) em função do número de golpes (determinação de c’).

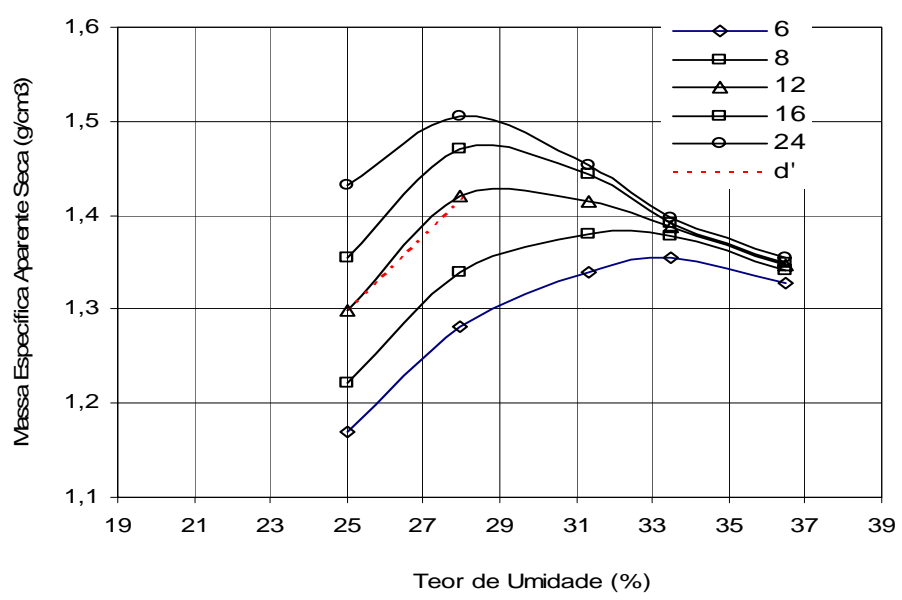

Figura 4.13 - Curvas de compactação com o número de golpes para cada teor de umidade (determinação de d').

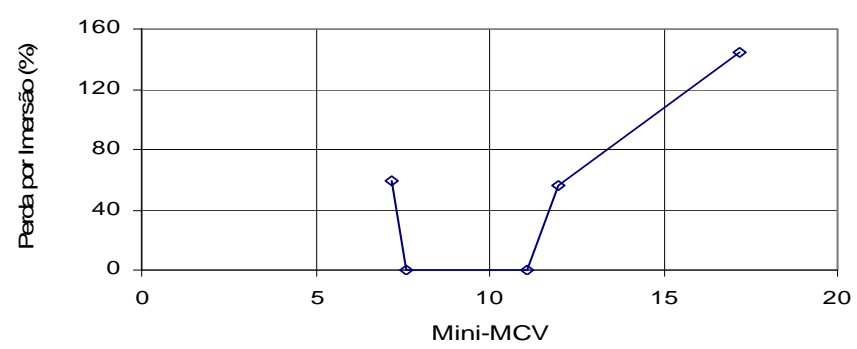

Figura 4.14 - Curva da Perda de Massa por Imersão em função do mini-MCV (determinação de PI). 
Nas Figuras 4.15 e 4.16 mostram-se os resultados obtidos para o solo jovem no ensaio Mini MCV e na Figura 4.17 mostra-se o resultado do ensaio de perda de massa por imersão.

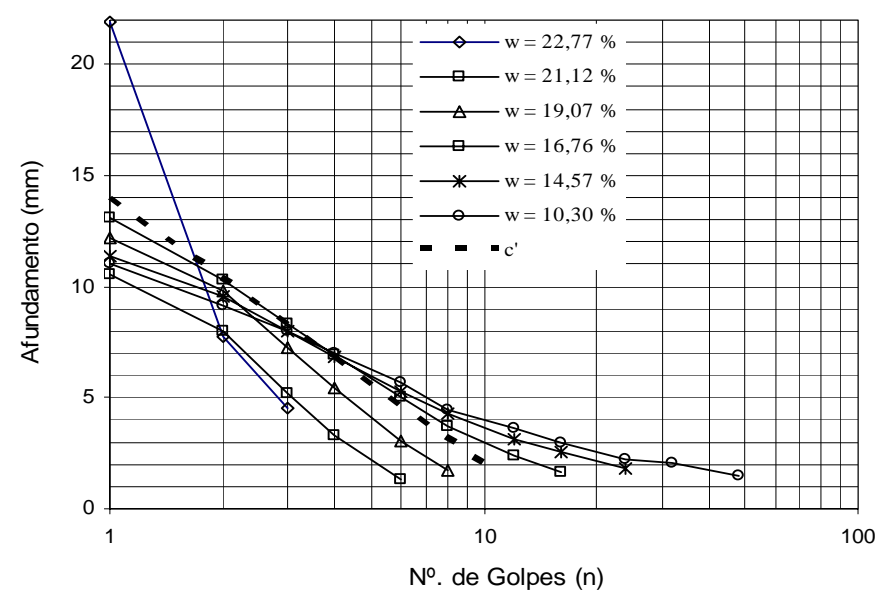

Figura 4.15 - Curvas de Afundamento (mm) em função do número de golpes (determinação de c’).

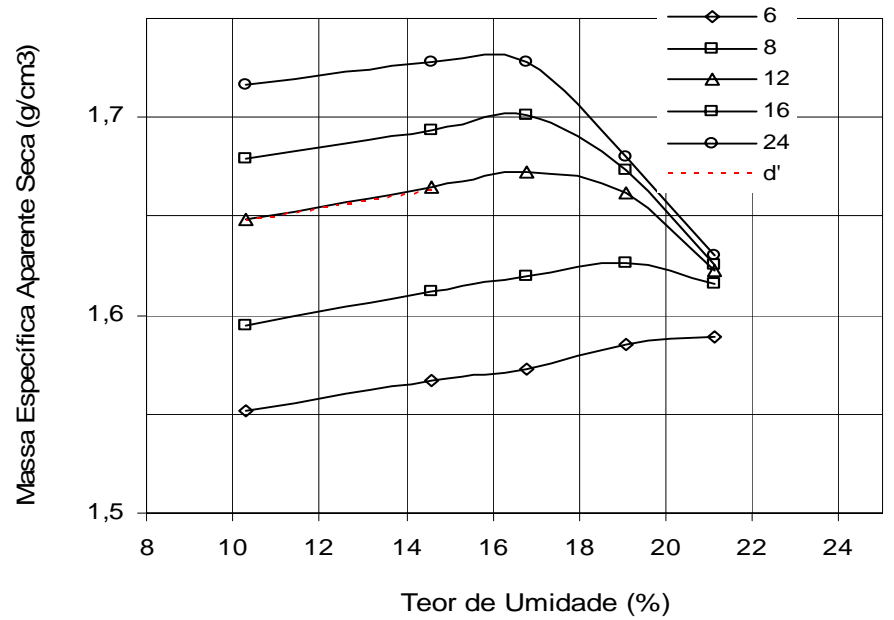

Figura 4.16 - Curvas de compactação com o número de golpes para cada teor de umidade (determinação de d').

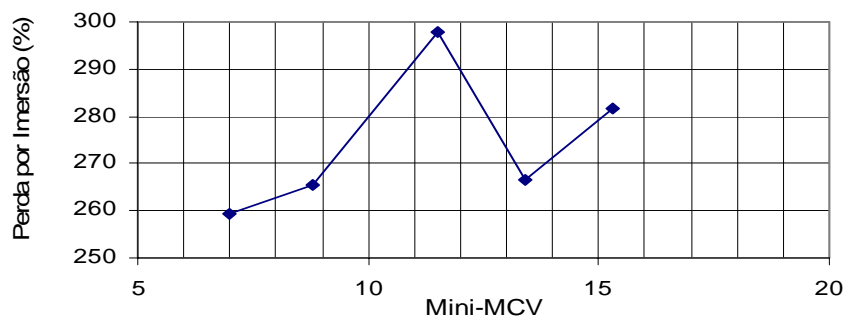

Figura 4.17 - Curva da Perda de Massa por Imersão em função do Mini-MCV (determinação de PI). 
Na Figura 4.18 mostra-se a classificação MCT obtida para os dois solos. O coeficiente e’ foi obtido através da seguinte formulação: $\left(\mathrm{Pi} / 100+20 / \mathrm{d}^{\prime}\right)^{1 / 3}$.

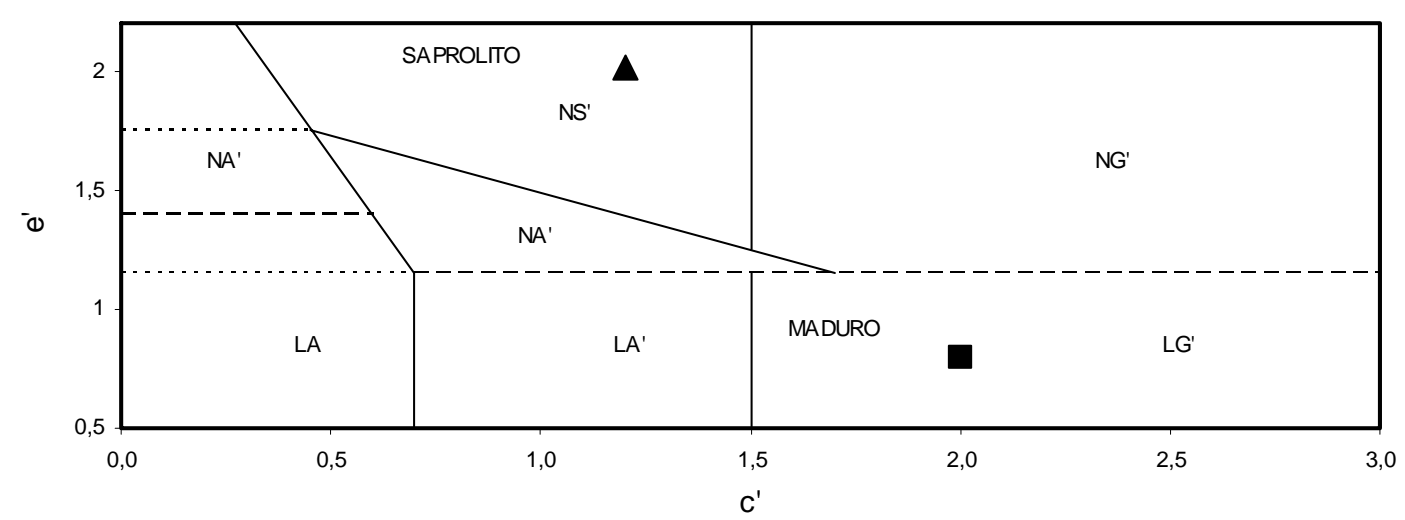

Figura 4.18 - Classificação MCT para os dois solos.

O solo residual maduro é classificado como LG’ (Laterítico Argiloso) e o solo jovem como NS’ (não laterítico siltoso).

\subsubsection{Curva Característica}

Na Figura 4.19 mostra-se a curva de retenção de água representada pela relação entre o teor de umidade gravimétrico versus sucção matricial, obtida para os dois solos.

pontos experimentais (solo maduro) - câmara de Richards

$\Delta$ pontos experimentais (solo jovem) - câmara de Richards

ajuste solo maduro (Van Genuchten). $\mathrm{W}_{\mathrm{S}}=42 \% ; \mathrm{W}_{\mathrm{r}}=19 \% ; \mathrm{m}=0,099 ; \mathrm{n}=1,11 ; \alpha=1,2 \mathrm{kPa}^{-1}$.

ajuste solo jovem (Van Genuchten). $W_{s}=28,8 \% ; \quad W_{r}=0,64 \% ; m=0,41 ; n=1 ; \alpha=0,02 \mathrm{kPa}^{-1}$.

ponto experimental solo jovem - papel filtro

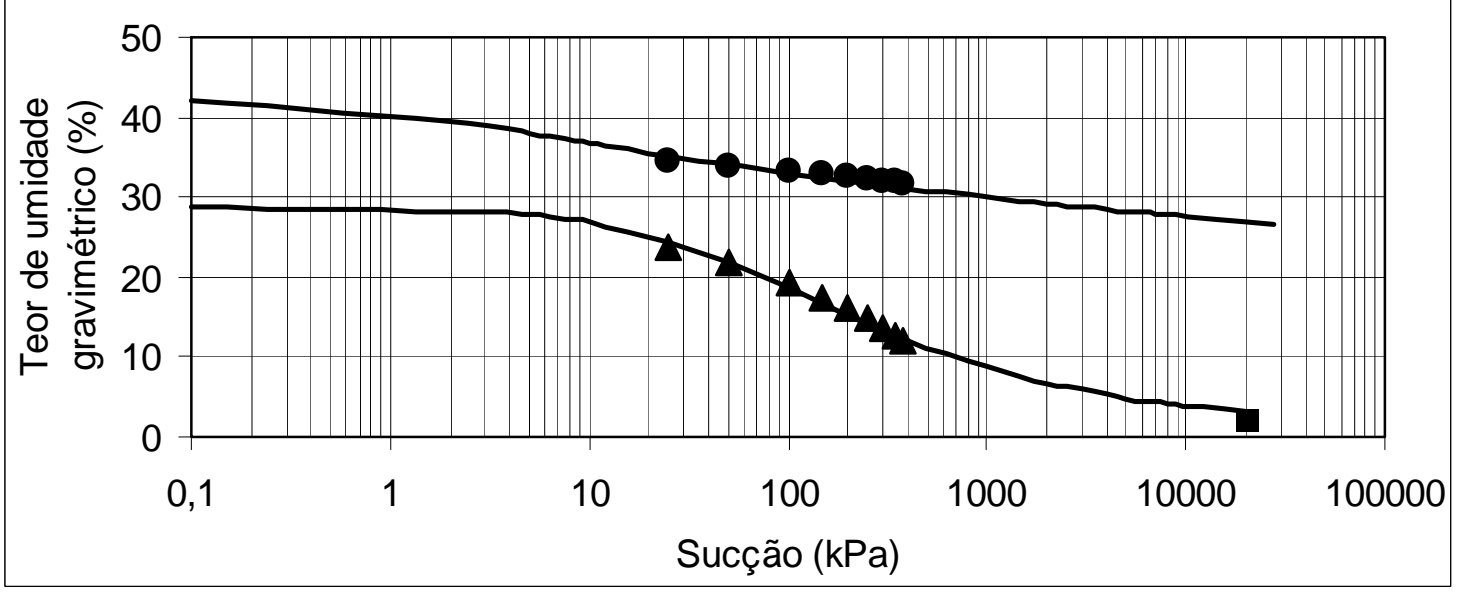

Figura 4.19 - Curva característica obtida para os dois solos. 


\subsubsection{Lâminas Delgadas}

Nas Figuras 4.20 a 4.25 mostram-se as lâminas obtidas, respectivamente, para o solo maduro e para o solo jovem.

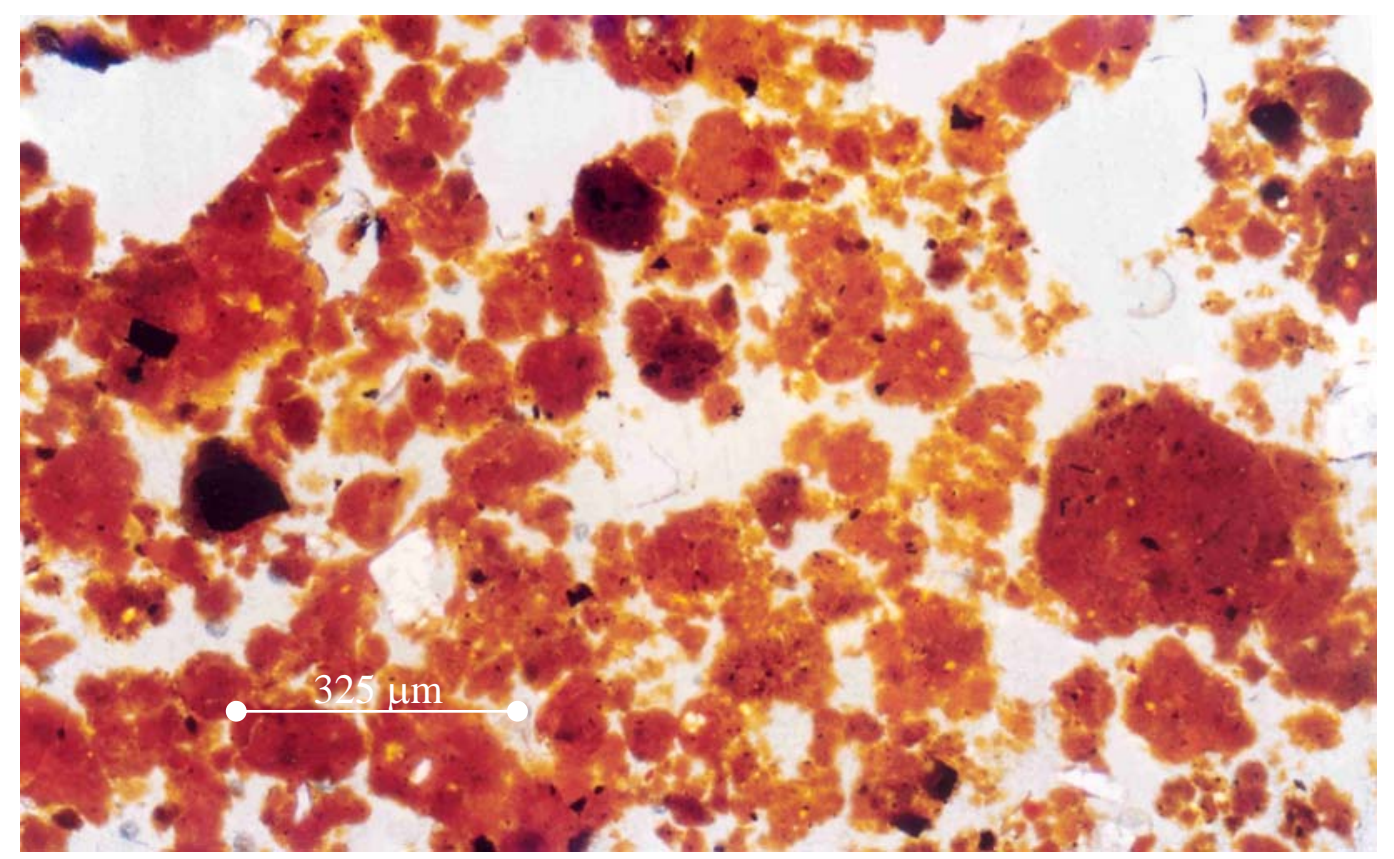

Figura 4.20 - Amostra indeformada do solo maduro observada ao microscópio ótico.

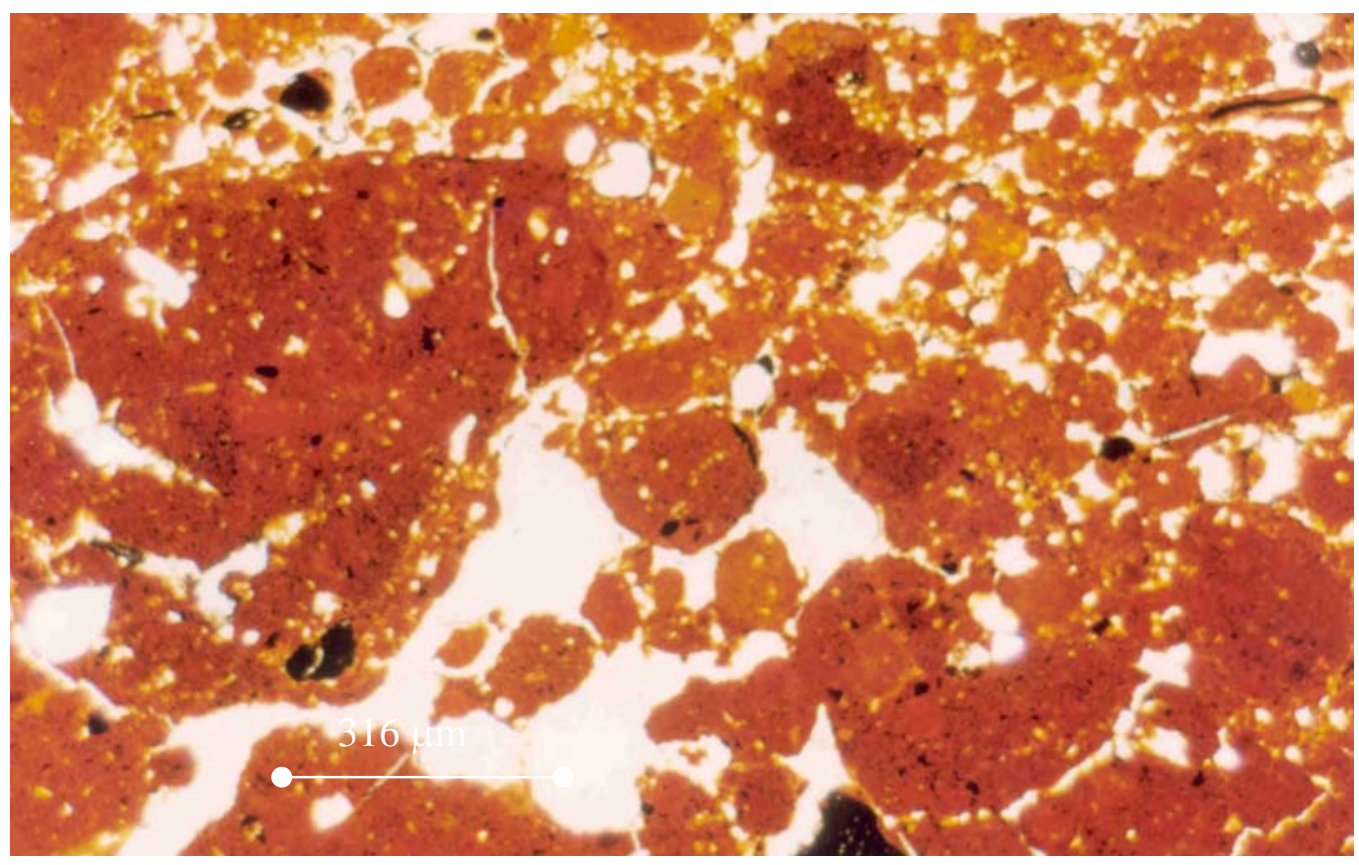

Figura 4.21 - Lâmina Delgada do solo maduro, revelando forte micro-estruturação granular, tonalidades vermelho-amarelas, abundantes carvões, nódulos ferruginosos e vazios interligados. Os teores de ferro cimentante são elevados. 


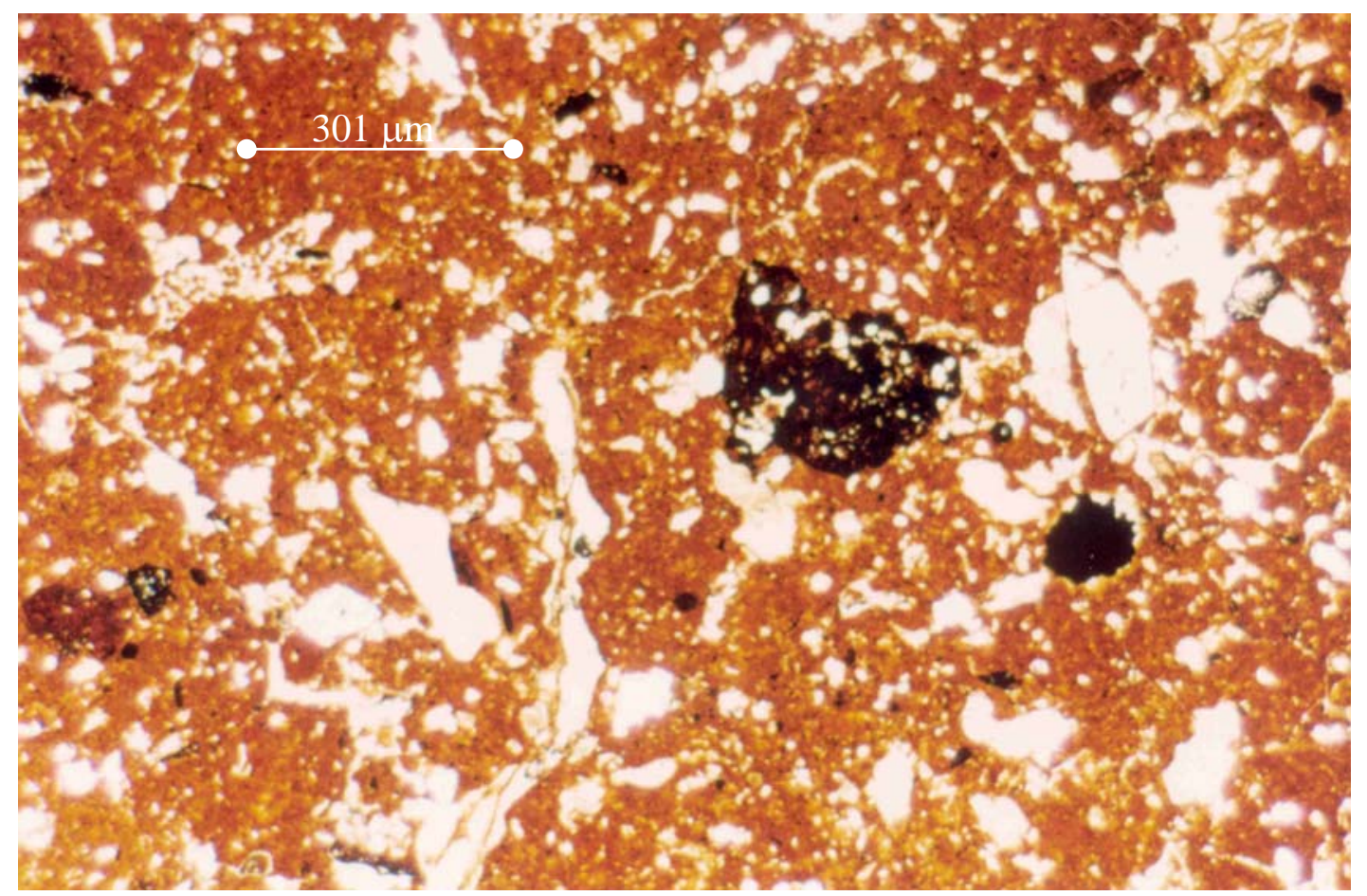

Figura 4.22 - Amostra do solo maduro evidenciando certa soldagem (coalescência) dos microagregados de forma ovóide, na parte mais compacta da amostra.

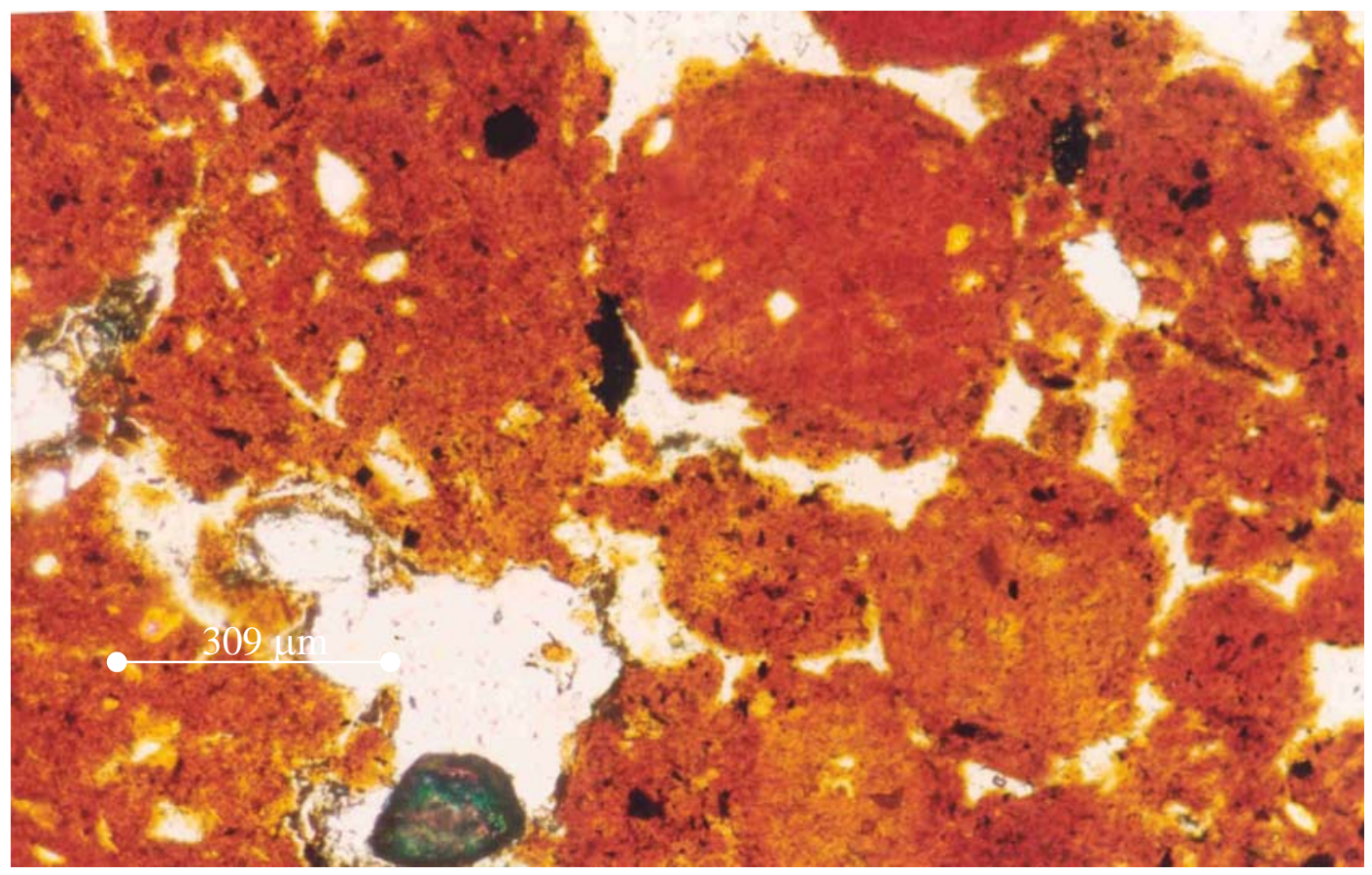

Figura 4.23 - Fotomicrografia da amostra do solo maduro mostrando a ligação entre os diversos blocos de microagregados. 


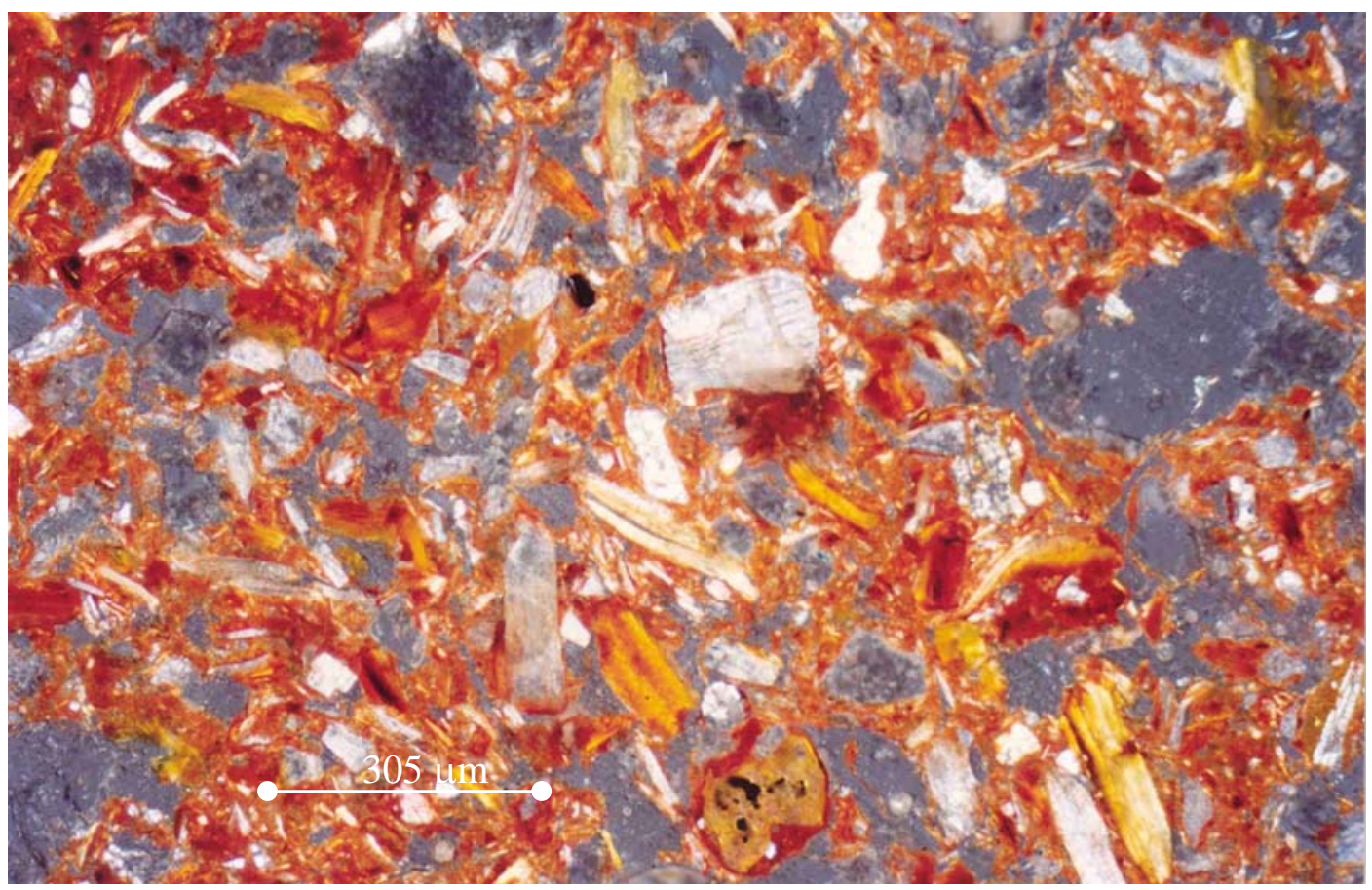

Figura 4.24 - Figura do solo saprolítico (jovem) mostrando detalhes da organização estrutural dos pseudomorfos de biotita orientados em relação ao plano horizontal (Luz plana).

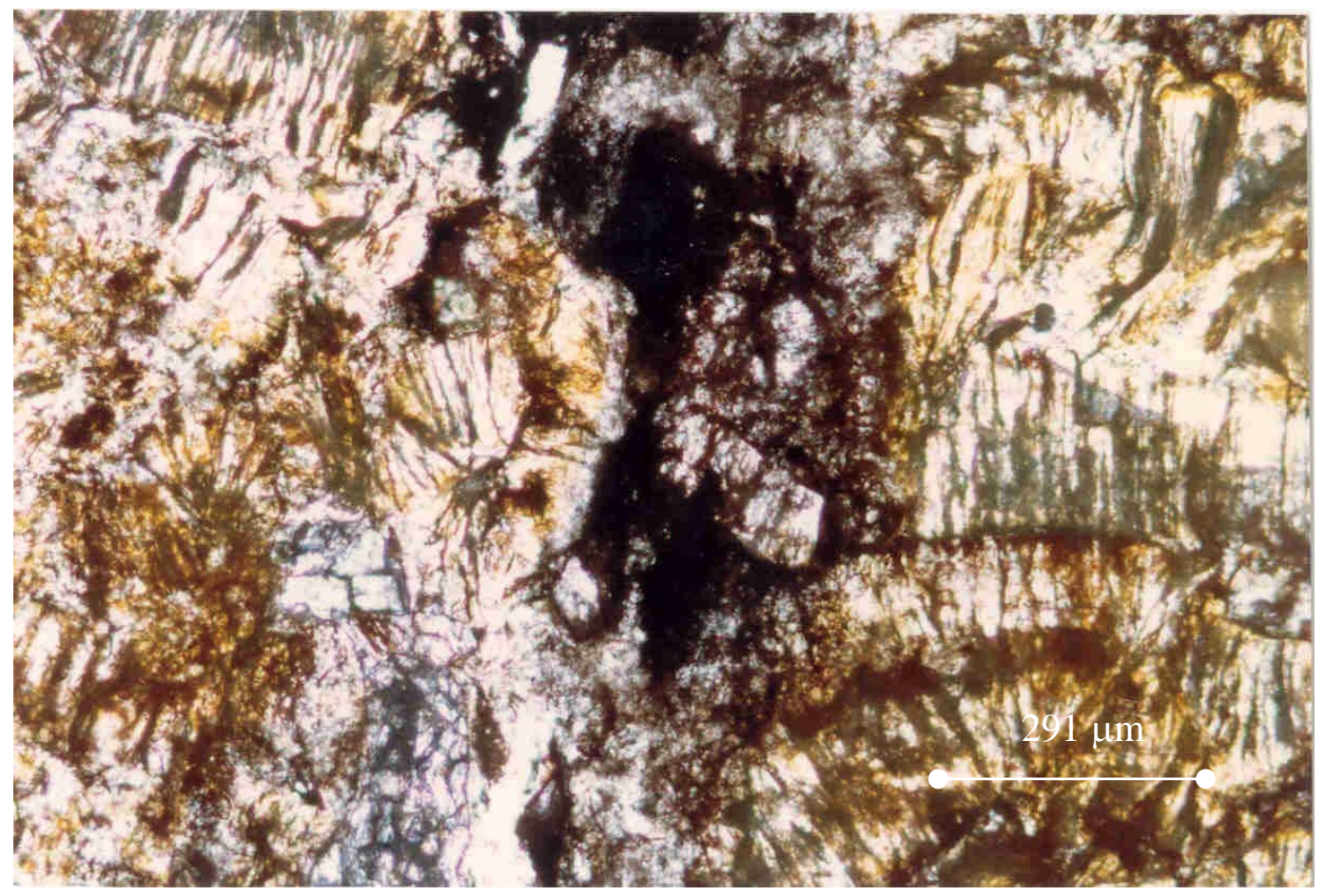

Figura 4.25 - Figura do solo saprolítico (jovem) mostrando detalhes da organização estrutural dos pseudomorfos de biotita orientados em relação ao plano horizontal (Luz plolarizada). 


\subsection{Ensaios Triaxiais}

\subsubsection{Ensaios drenados em amostras saturadas por contrapressão}

Nas Figuras 4.26 a 4.31 mostram-se os resultados dos ensaios de compressão triaxial drenados $\left(\mathrm{CID}_{\text {sat }}\right)$, em que a ruptura se deu por compressão axial. Nestes ensaios os corpos de prova foram inicialmente saturados por contra pressão e adensados isotropicamente. Os ensaios estão agrupados de acordo com a direção de carregamento.

(a)

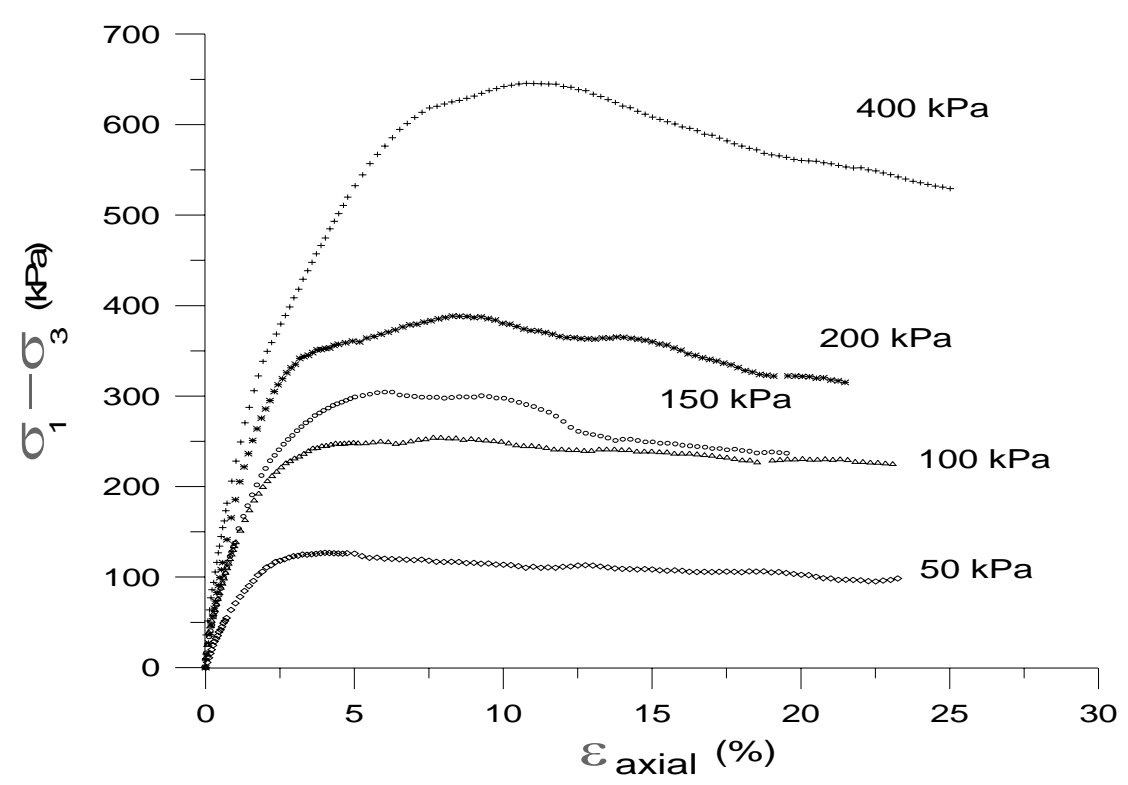

(b)

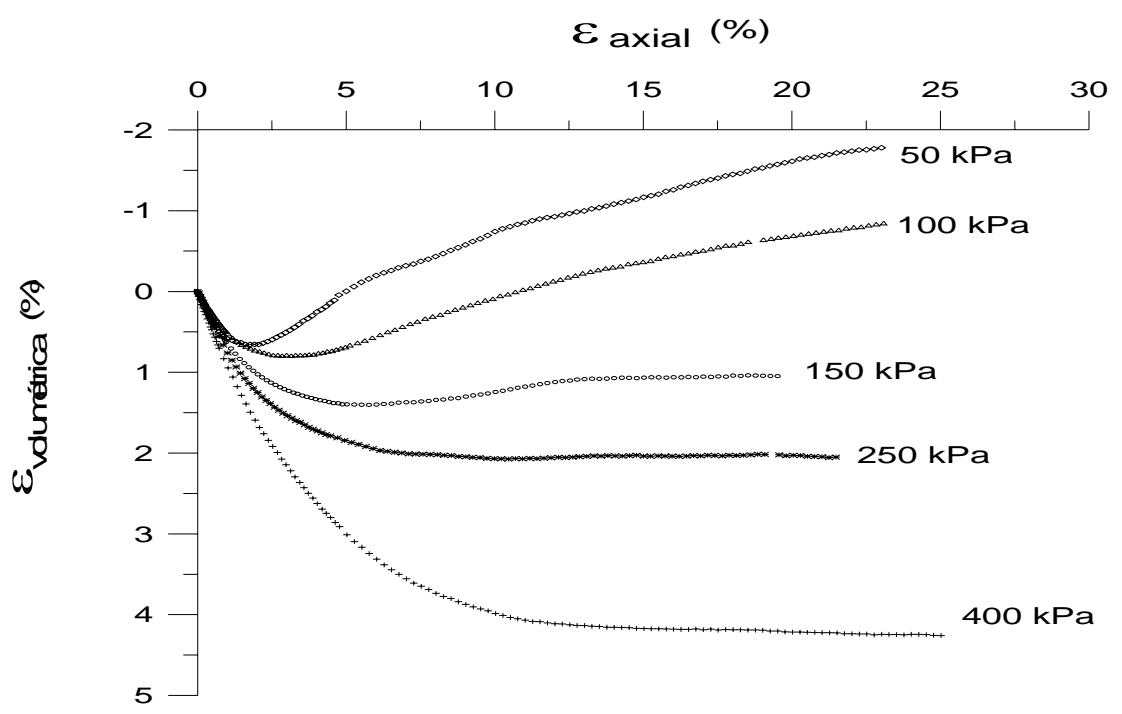

Figura 4.26 - Resultados dos ensaios CID $_{\text {sat }}$, solo jovem, para a direção vertical: a) $\left(\sigma_{1}-\sigma_{3}\right) \times \varepsilon_{\text {axial }}$, b) $\varepsilon_{\mathrm{v}}$ $\mathrm{x} \varepsilon_{\text {axial }}$. 
(a)

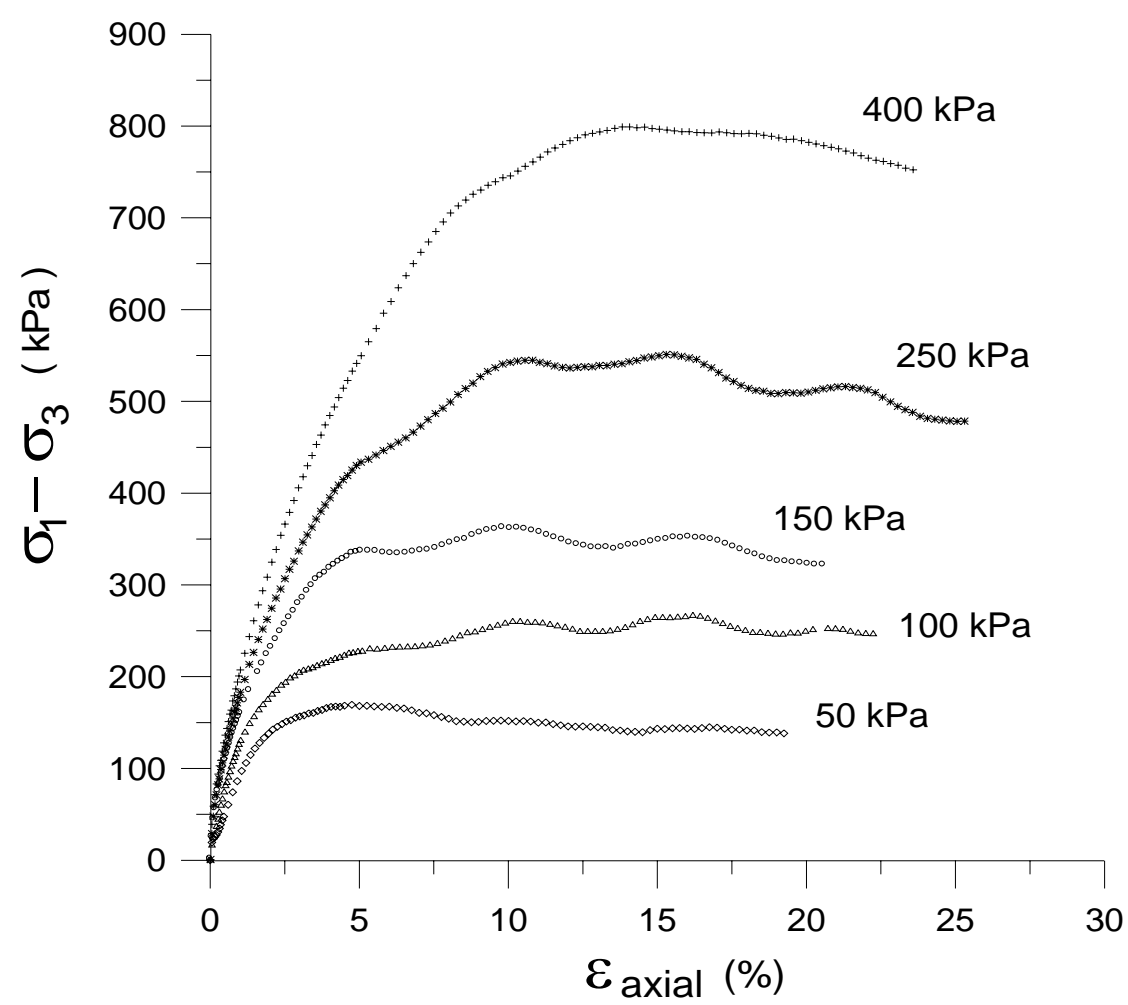

(b)

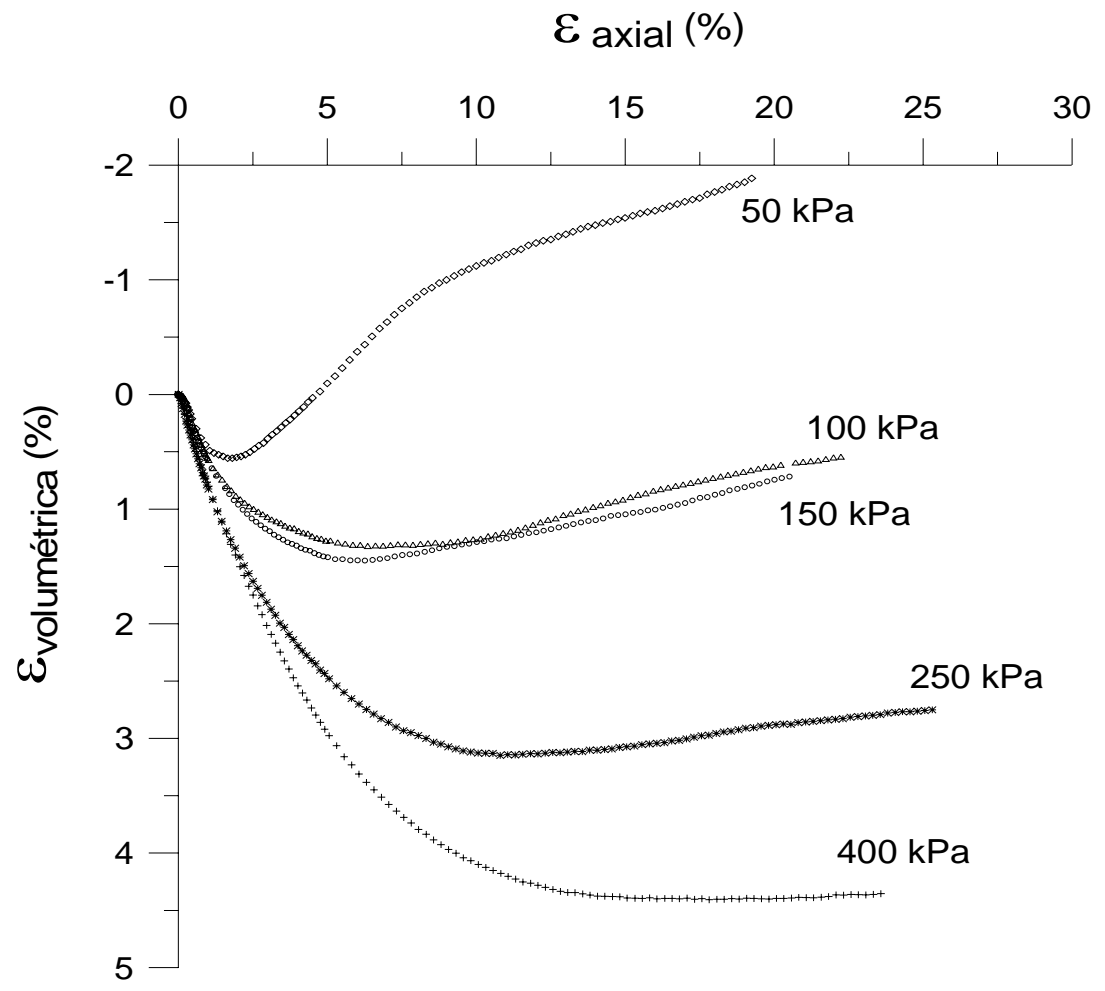

Figura 4.27 - Resultados dos ensaios $\operatorname{CID}_{\text {sat, }}$, solo jovem, para a direção paralela ao bandamento: a) $\left(\sigma_{1}\right.$ $\left.\sigma_{3}\right) \mathrm{x} \varepsilon_{\text {axial }}$, b) $\varepsilon_{\mathrm{v}} \mathrm{x} \varepsilon_{\text {axial. }}$. 
(a)

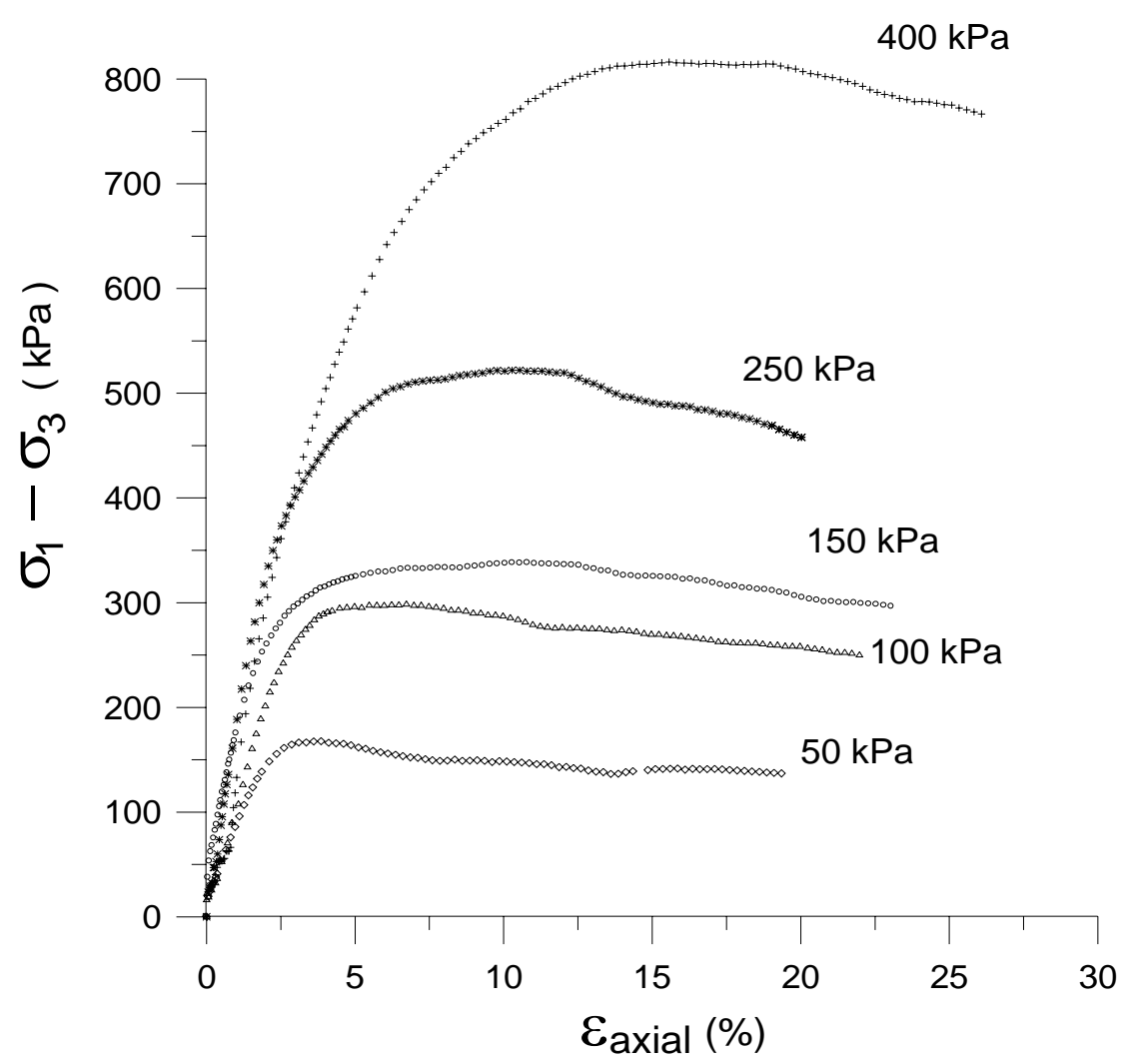

(b)

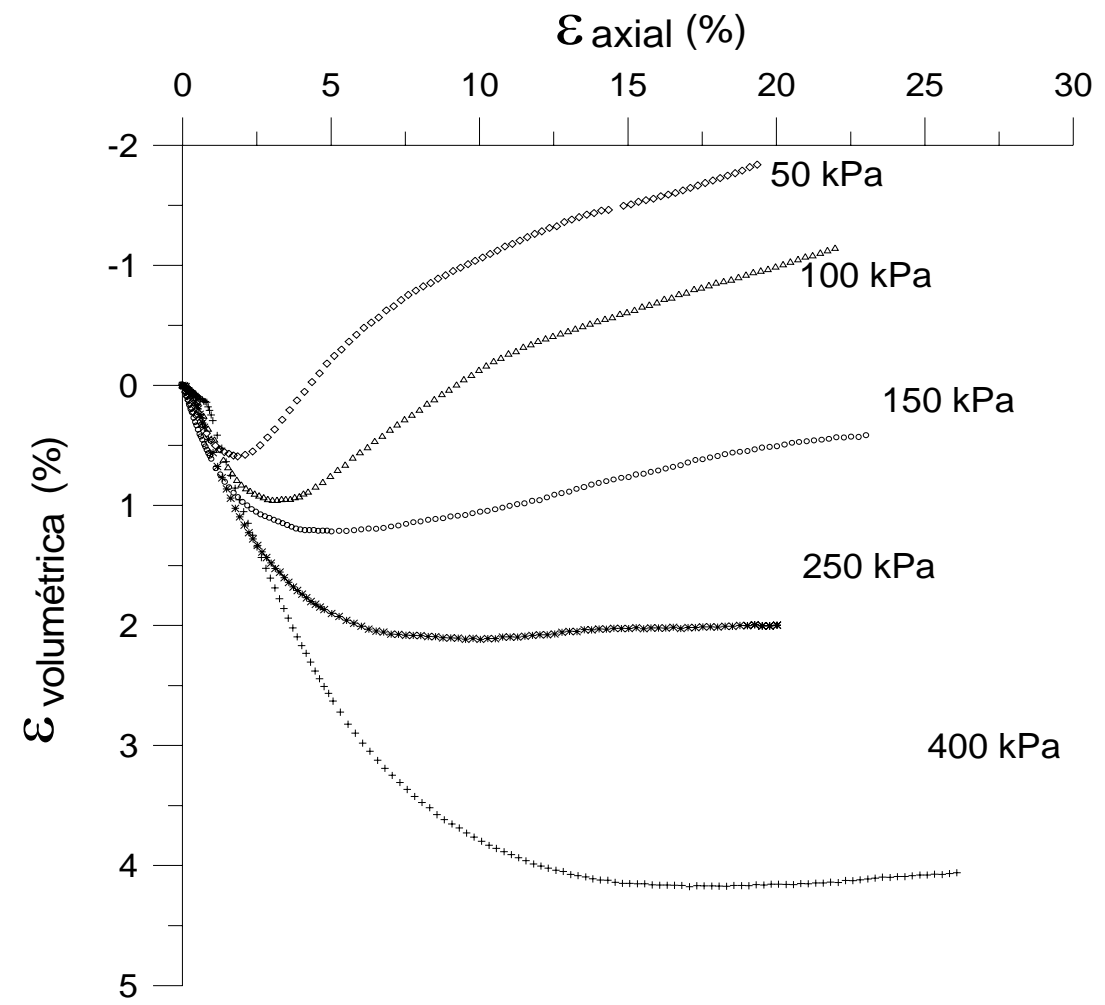

Figura 4.28 - Resultados dos ensaios $\operatorname{CID}_{\text {sat }}$, solo jovem, direção perpendicular ao bandamento: a) $\left(\sigma_{1}-\sigma_{3}\right)$ $\mathrm{x} \varepsilon_{\text {axial }}$, b) $\varepsilon_{\mathrm{v}} \mathrm{x} \varepsilon_{\text {axial. }}$. 
(a)

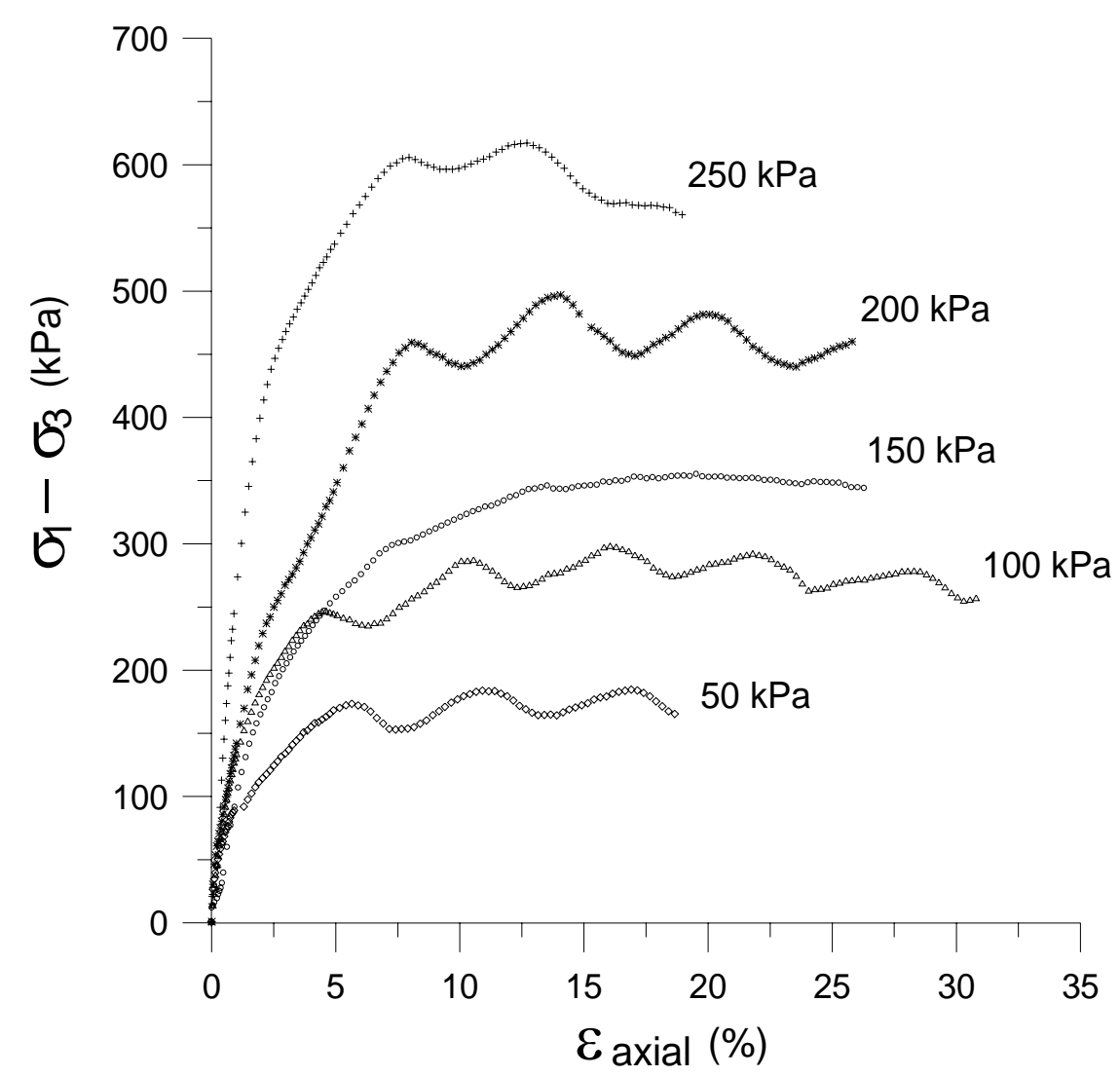

(b)

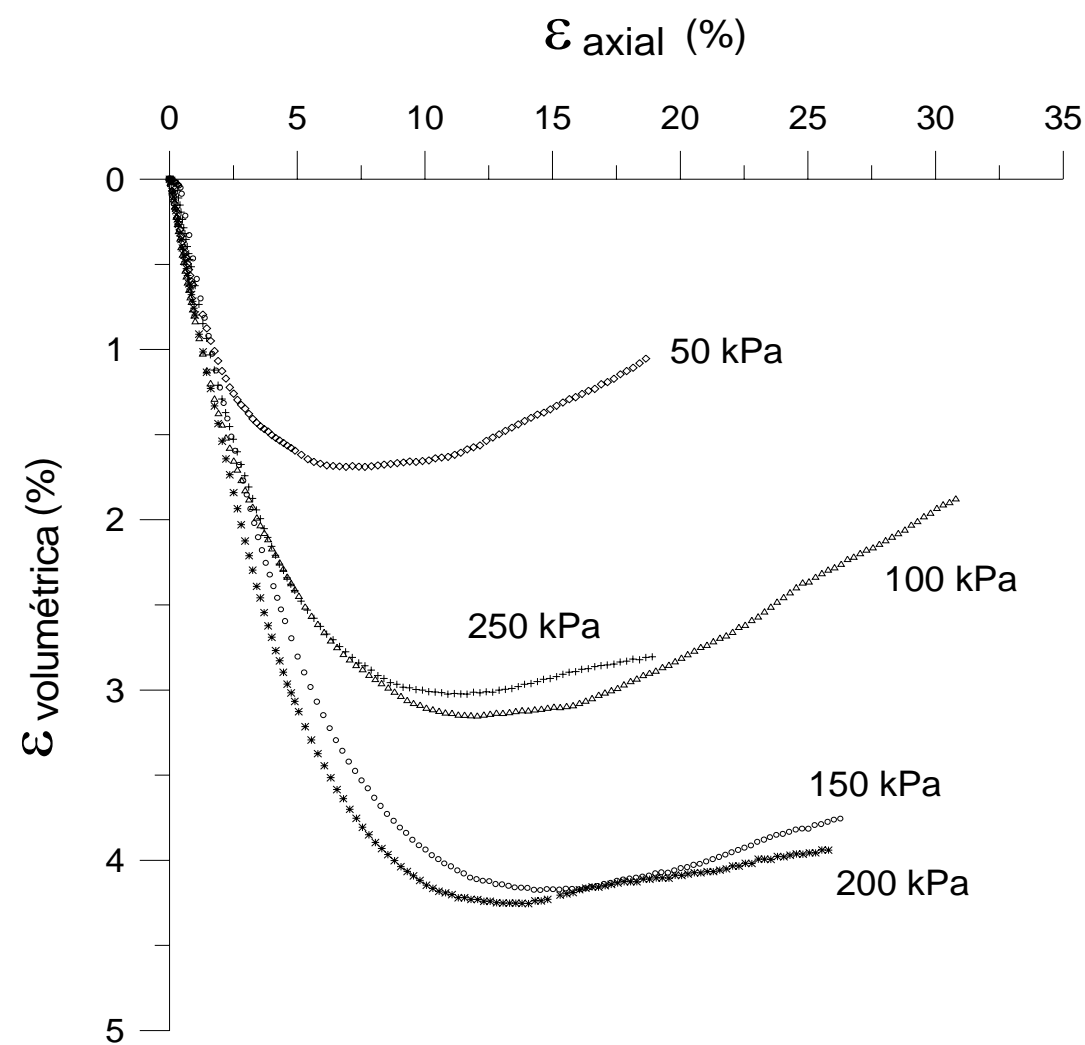

Figura 4.29 - Resultados dos ensaios $\operatorname{CID}_{\text {sat }}$, solo maduro, para a direção vertical: a) $\left(\sigma_{1}-\sigma_{3}\right)$ x $\varepsilon_{\text {axial }}$, b) $\varepsilon_{\mathrm{v}}$ $\mathrm{x} \varepsilon_{\text {axial. }}$. 

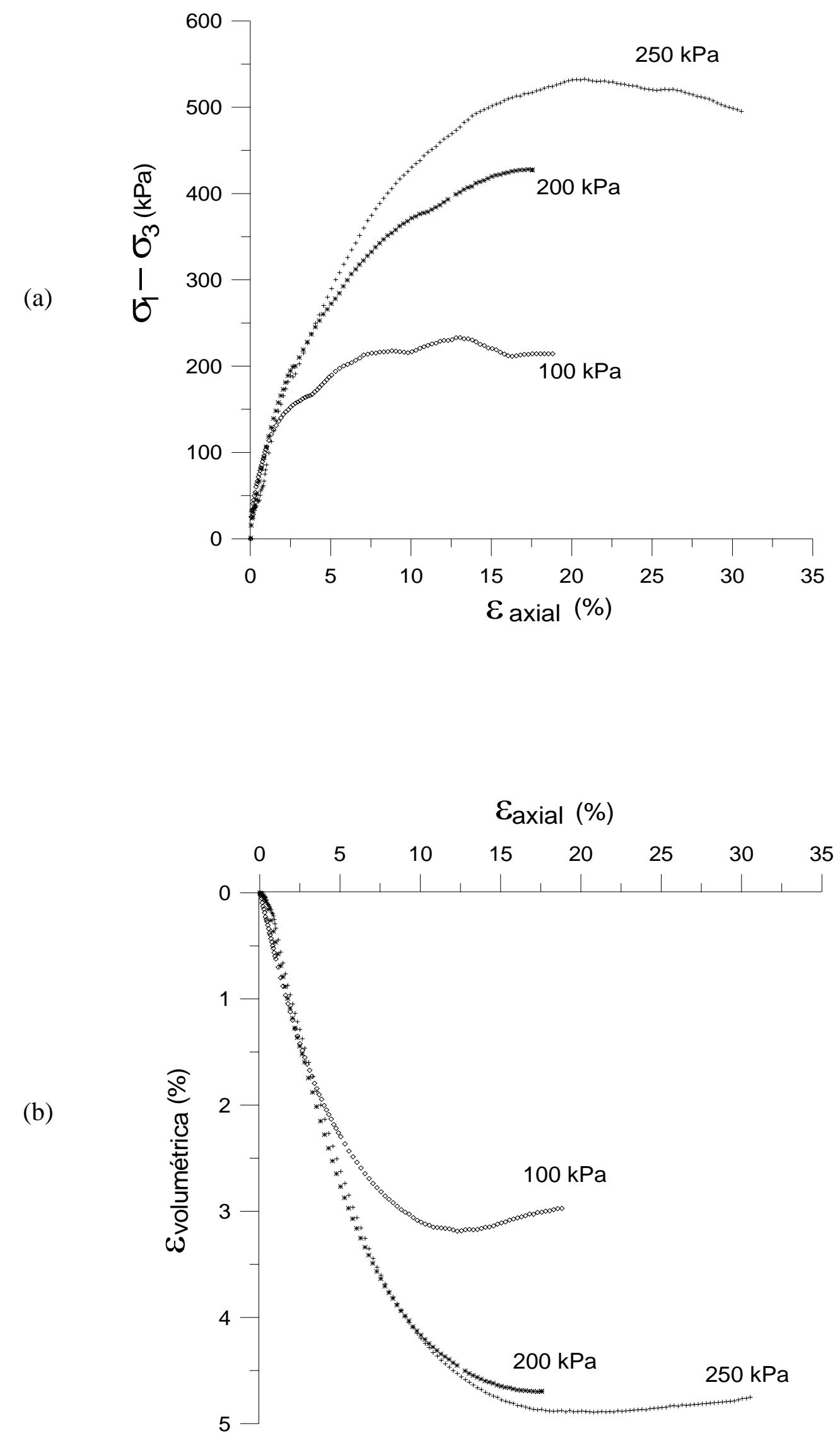

Figura 4.30 - Resultados dos ensaios CID $_{\text {sat }}$, solo maduro para a direção horizontal : a) $\left(\sigma_{1}-\sigma_{3}\right) \times \varepsilon_{\text {axial }}$, b) $\varepsilon_{\mathrm{v}} \mathrm{x} \varepsilon_{\text {axial }}$. 
(a)

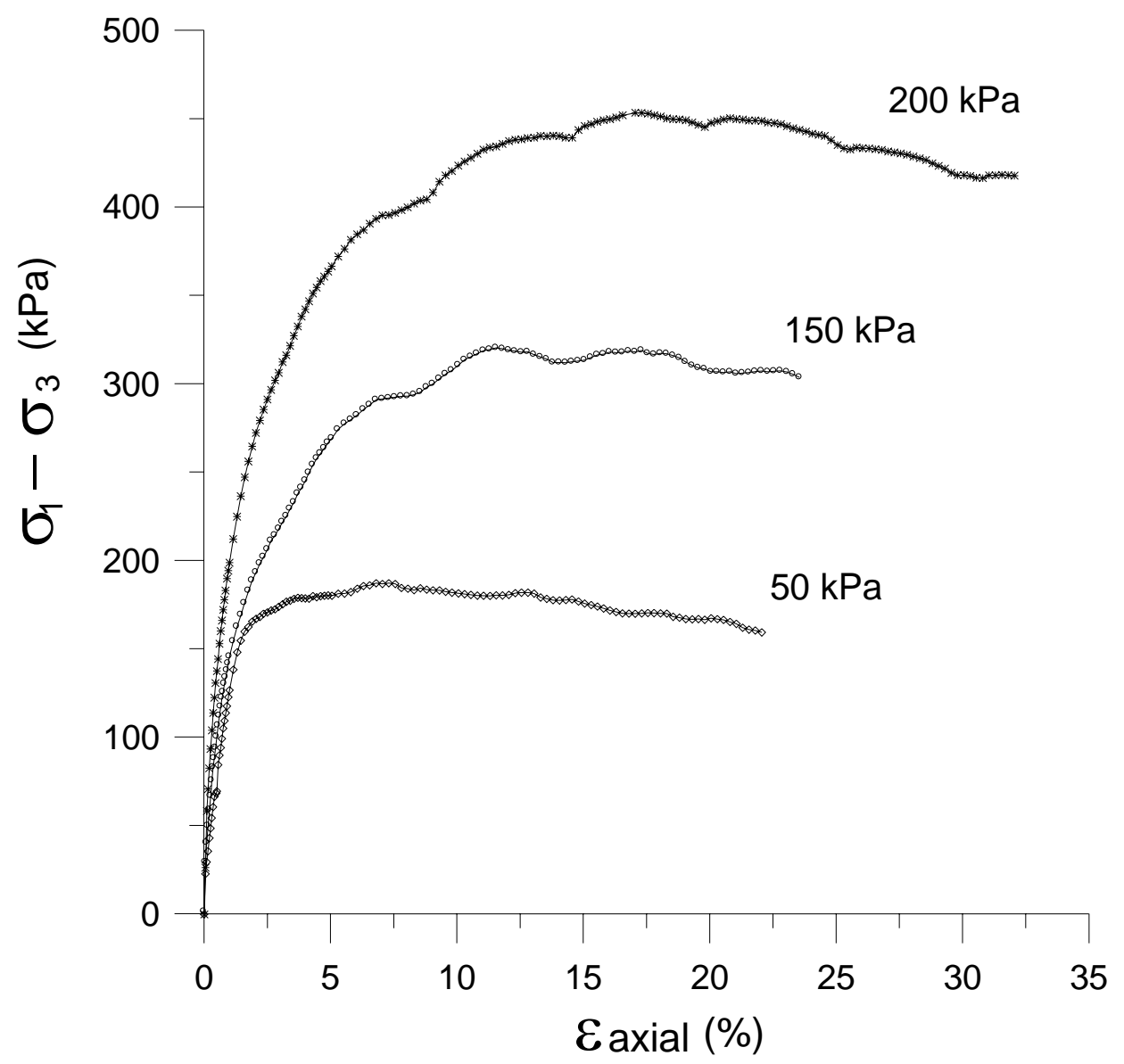

(b)

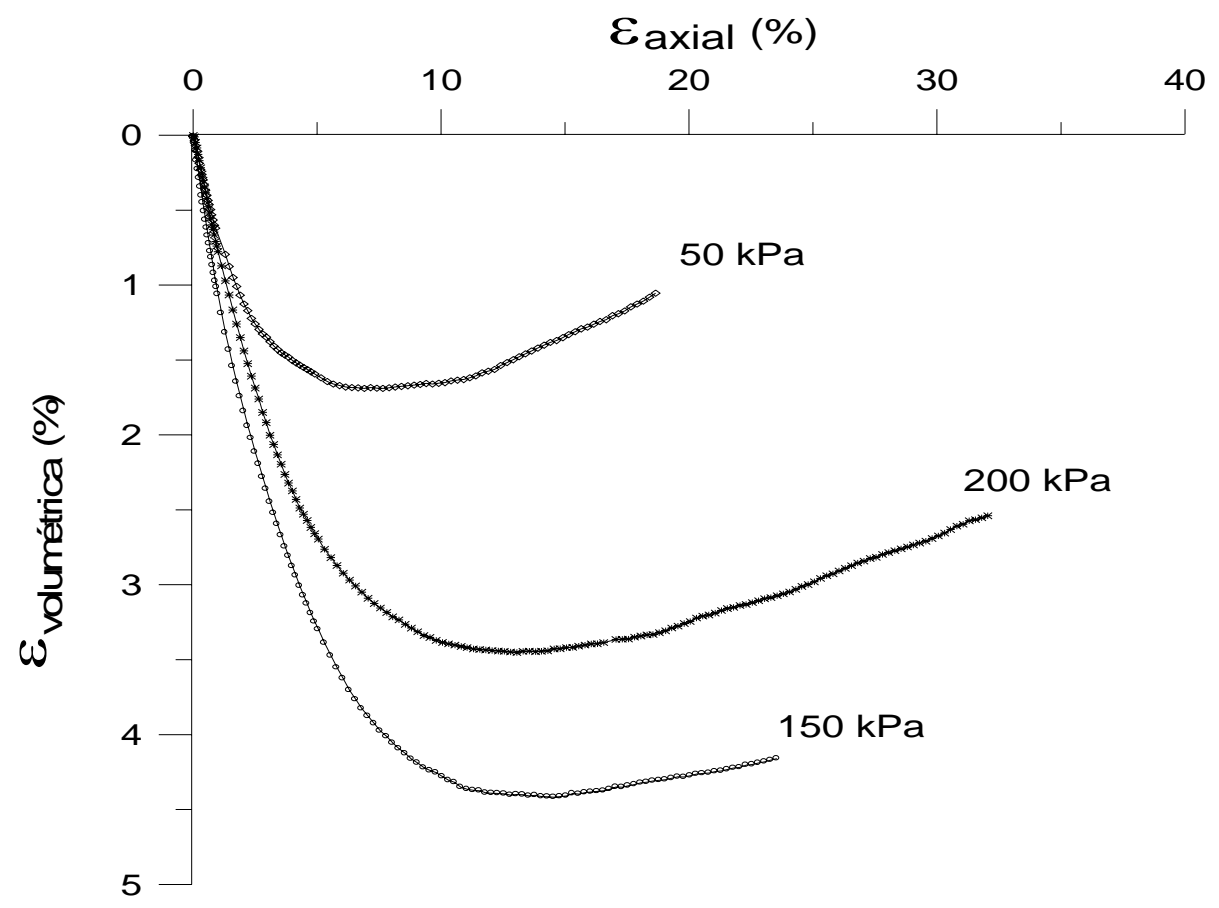

Figura 4.31 - Resultados dos ensaios $\operatorname{CID}_{\text {sat }}$, solo maduro, para a direção de $45^{\circ}$ : a) $\left(\sigma_{1}-\sigma_{3}\right) \times \varepsilon_{\text {axial }}$, b) $\varepsilon_{\mathrm{v}}$ $\mathrm{x} \varepsilon_{\text {axial }}$. 
Na Figura 4.32 mostra-se os resultados dos ensaios triaxiais em trajetórias diferentes da convencional realizados no solo jovem.

(a)

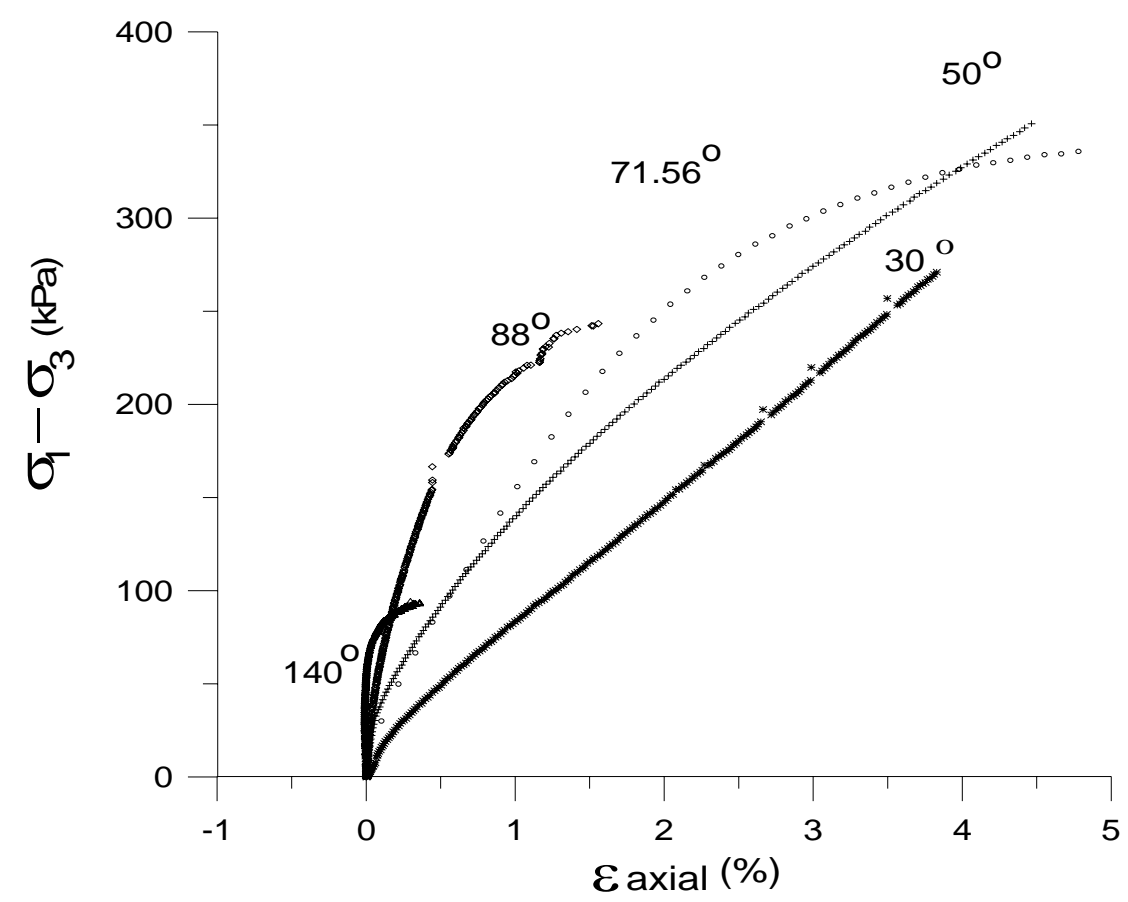

(b)

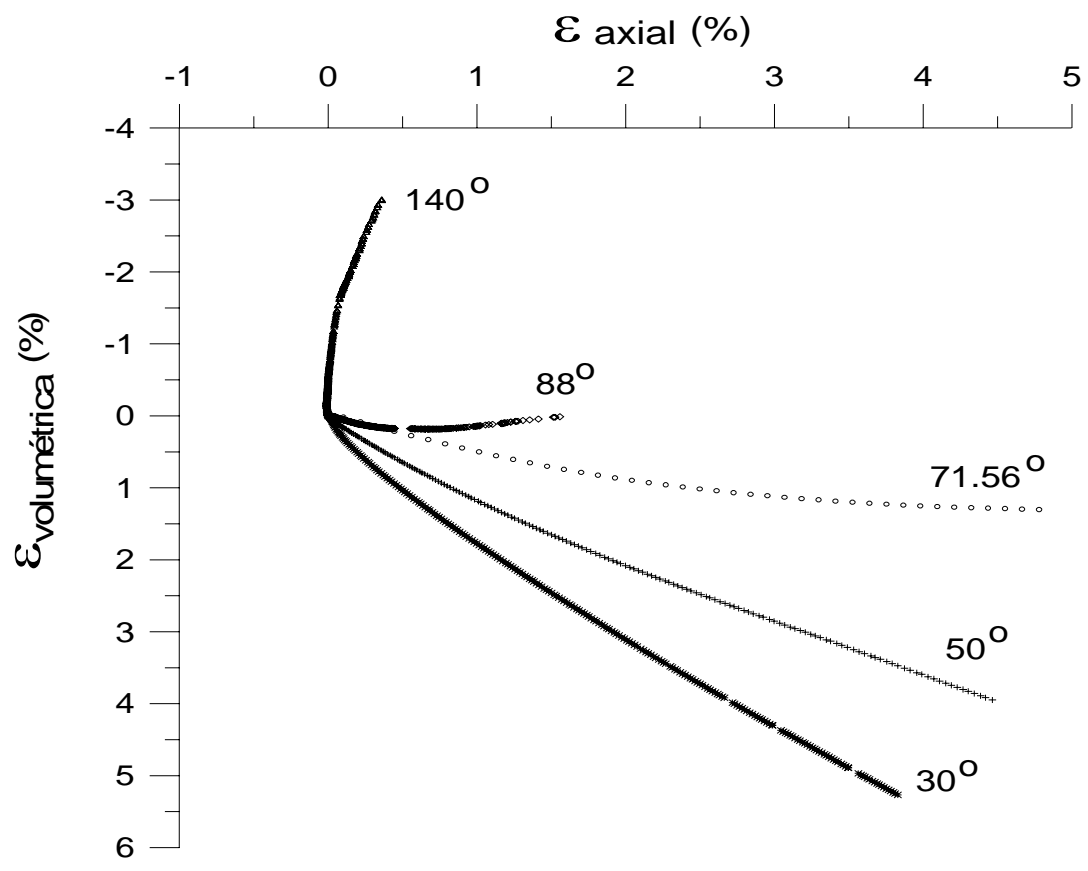

Figura 4.32 - Resultados dos ensaios em trajetórias diferentes da convencional, realizados na célula Bishop Wesley, para o solo jovem: a) $\left(\sigma_{1}-\sigma_{3}\right) \mathrm{x} \varepsilon_{\mathrm{axial}}$, b) $\varepsilon_{\mathrm{v}} \mathrm{x} \varepsilon_{\mathrm{axial}}$. 
Nas Figuras 4.33 e 4.34 mostram-se os resultados dos ensaios de compressão hidrostática realizados, respectivamente, nos solos jovem e maduro.

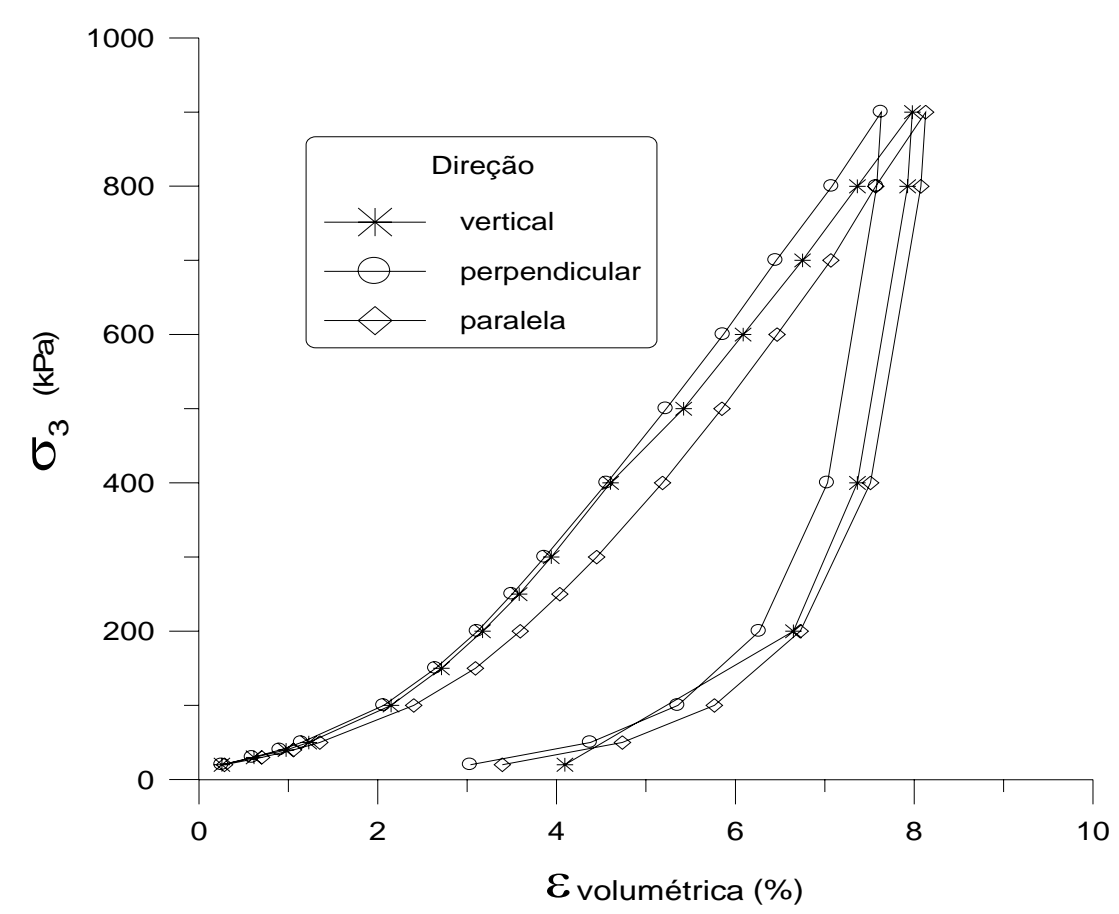

Figura 4.33 - Resultado dos ensaios de compressão hidrostática realizados no solo jovem.

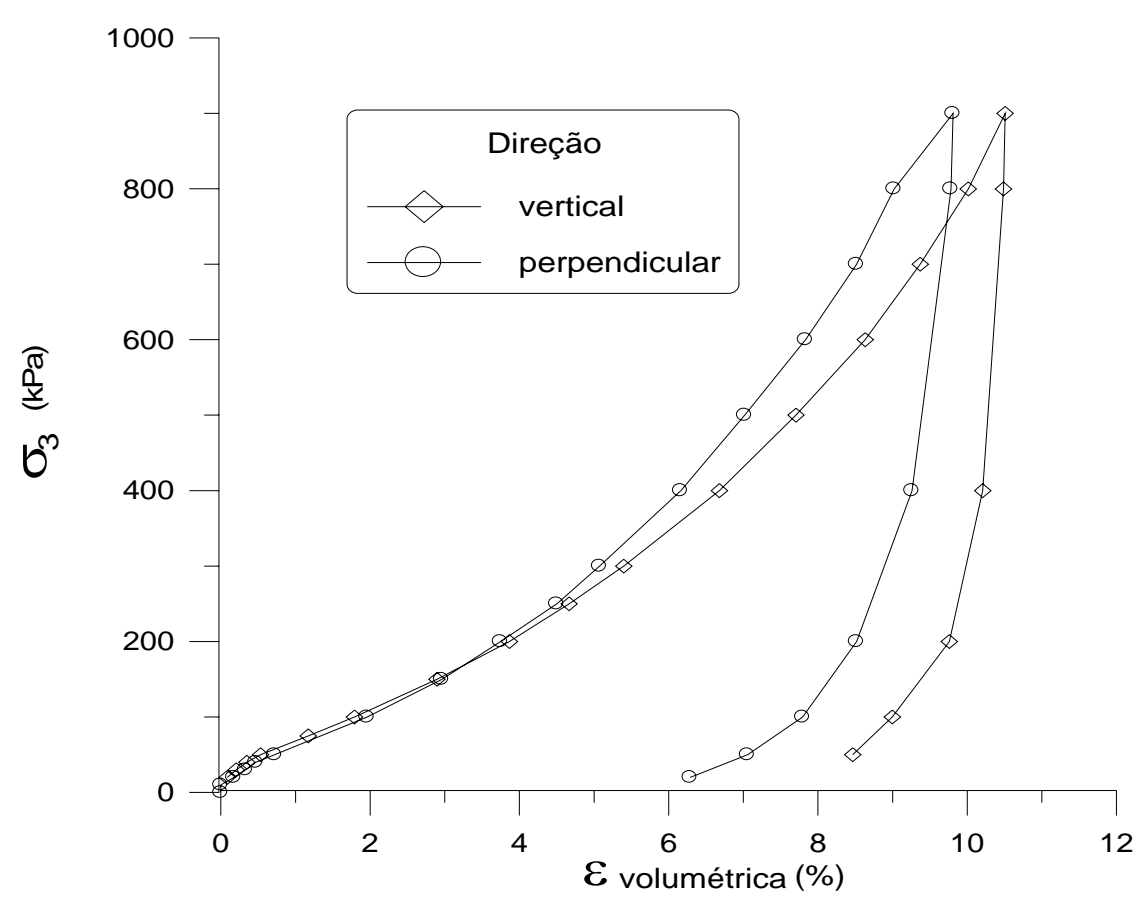

Figura 4.34 - Resultado dos ensaios de compressão hidrostática realizados no solo maduro. 


\subsubsection{Ensaios em amostras não saturadas}

\subsubsection{Ensaios com sucção matricial $\left(\mathrm{u}_{\mathrm{a}}-\mathrm{u}_{\mathrm{w}}\right)$ controlada}

Nas Figuras 4.35 a 4.42 mostram-se os resultados dos ensaios triaxiais de compressão axial ( $\sigma_{3}$ constante), consolidados isotropicamente e drenados (CID), realizados na prensa Bishop Wesley servo controlada e com instrumentação interna, respectivamente, para o solo jovem e o solo maduro nas sucções de 40 kPa, 80 kPa, 160 kPa e 320 kPa.

(a)

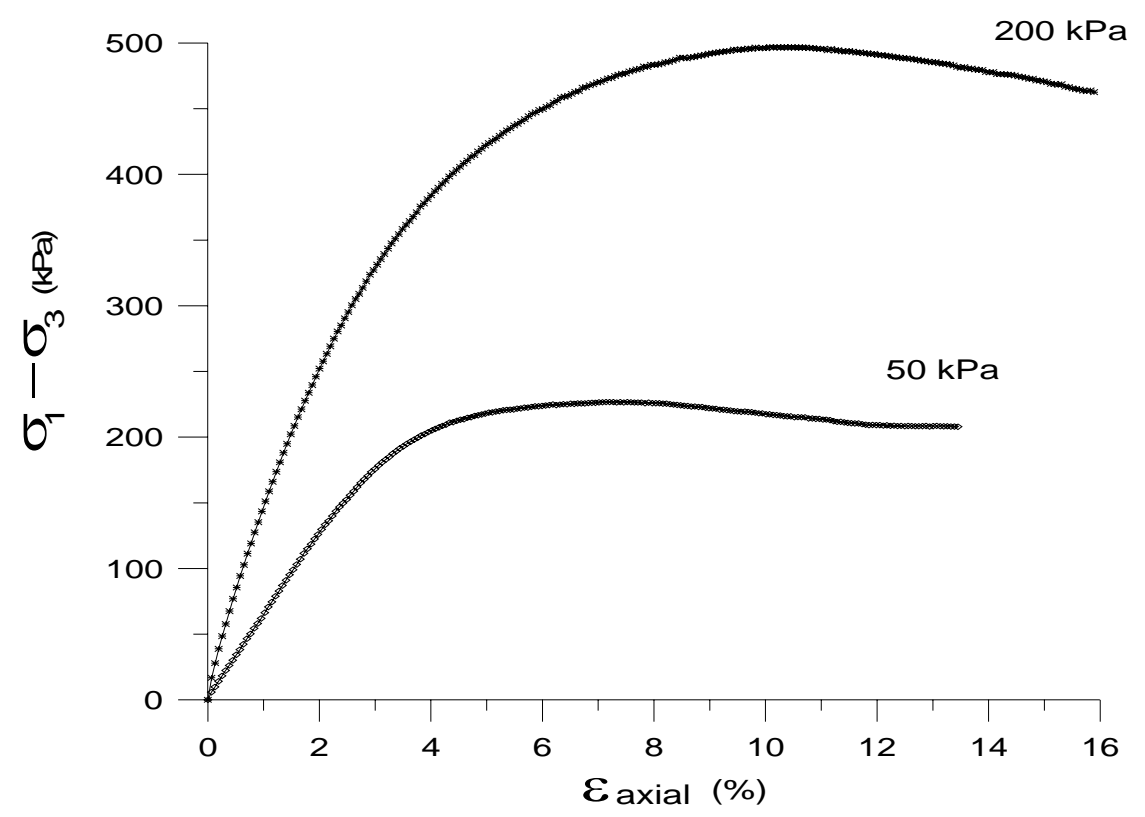

(b)

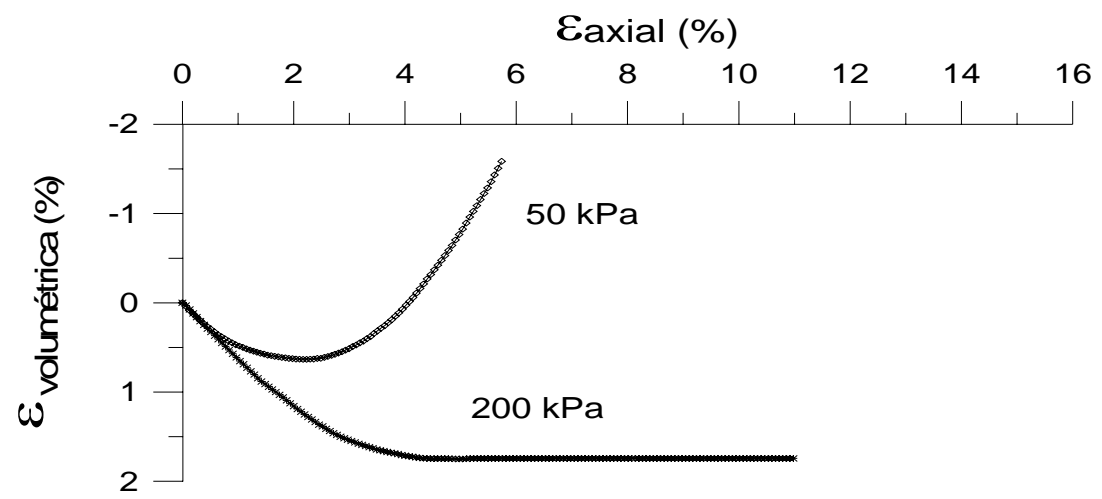

Figura 4.35 - Resultados dos ensaios CID, solo jovem, para $u_{a}-u_{w}=40 \mathrm{kPa}$ a) $\left(\sigma_{1}-\sigma_{3}\right) \times \varepsilon_{\text {axial }}$, b) $\varepsilon_{v} \mathrm{x}$ $\varepsilon_{\text {axial. }}$. 
(a)

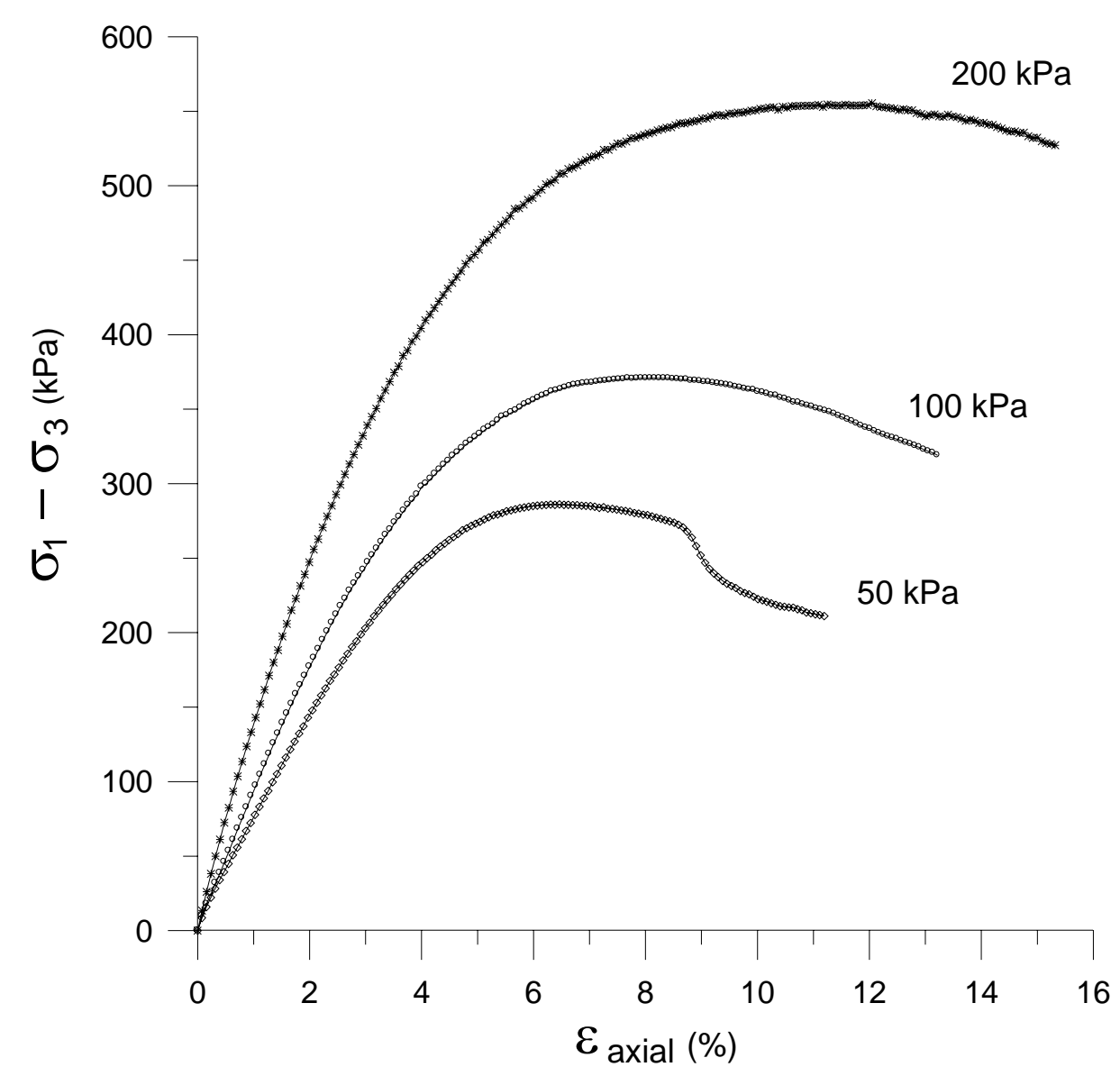

(b)

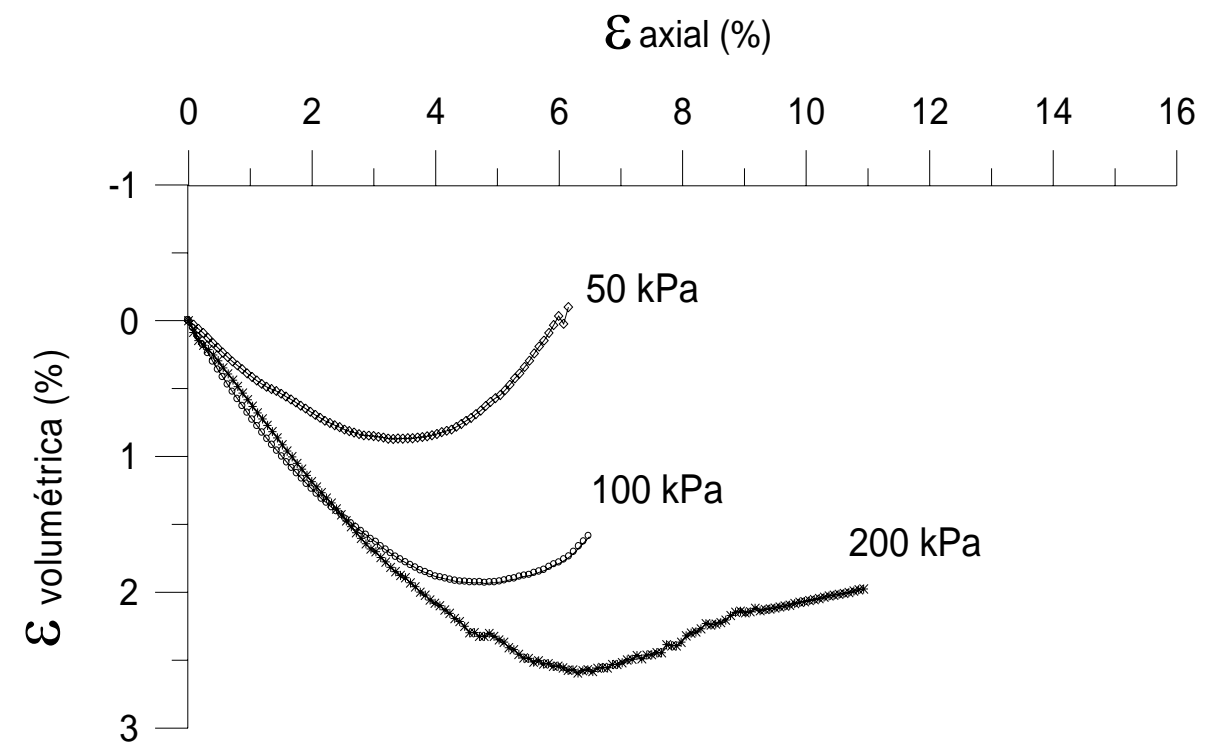

Figura 4.36 - Resultados dos ensaios CID, solo jovem, para $\mathrm{u}_{\mathrm{a}}-\mathrm{u}_{\mathrm{w}}=80 \mathrm{kPa}$ : a) $\left(\sigma_{1}-\sigma_{3}\right) \mathrm{x} \varepsilon_{\mathrm{axial}}$, b) $\varepsilon_{\mathrm{v}} \mathrm{x}$ $\varepsilon_{\text {axial }}$. 
(a)

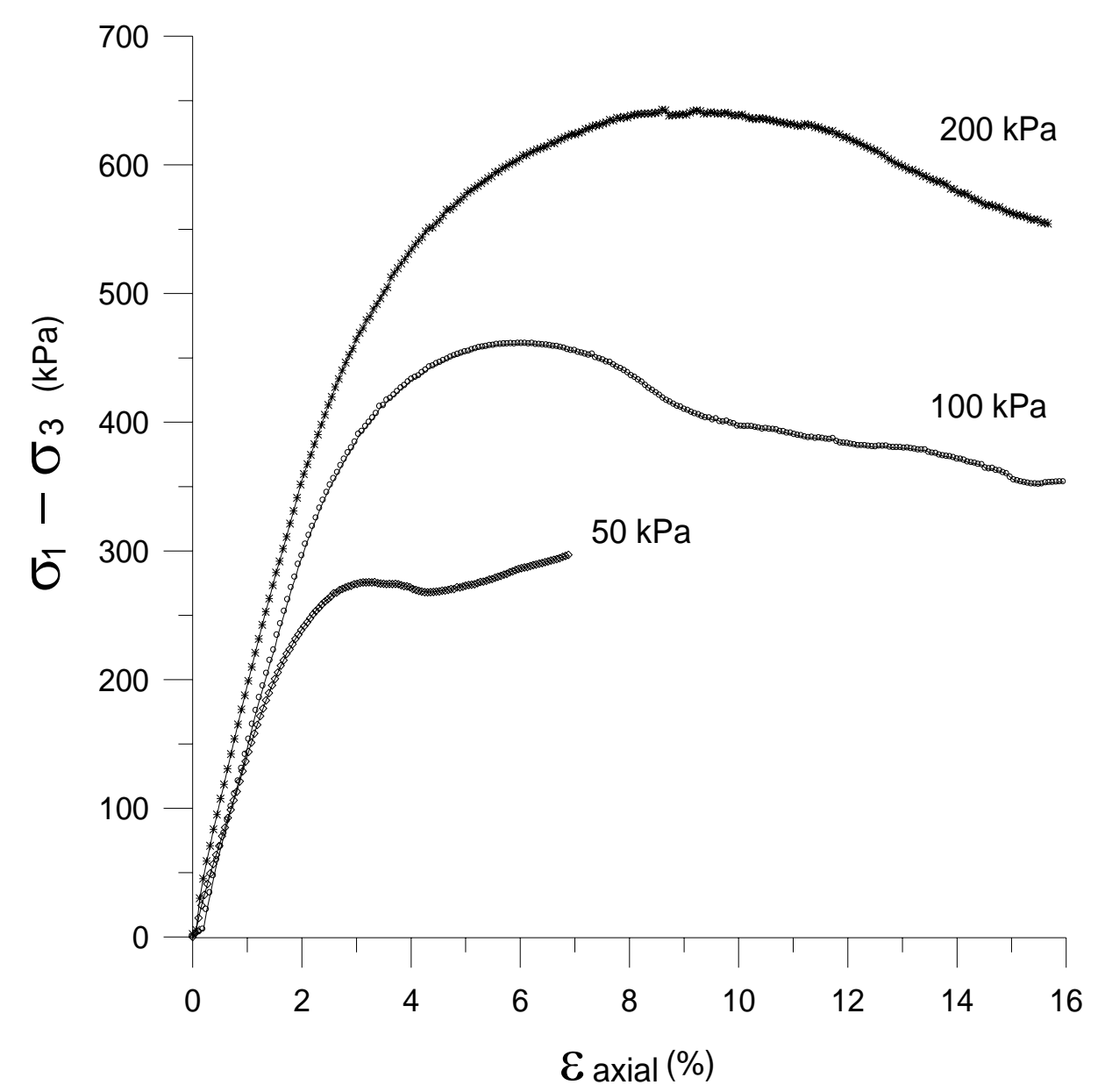

(b)

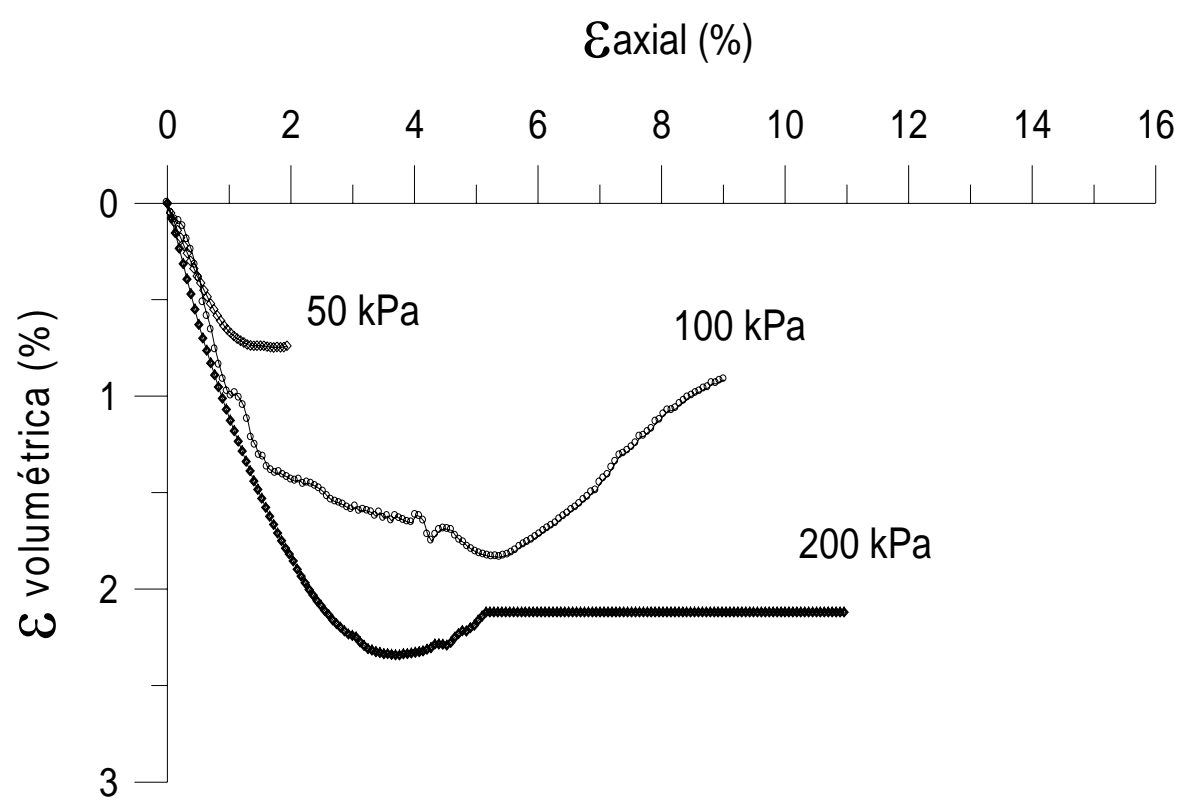

Figura 4.37 - Resultados dos ensaios CID, solo jovem, para $\mathrm{u}_{\mathrm{a}}-\mathrm{u}_{\mathrm{w}}=160 \mathrm{kPa}$ a) $\left(\sigma_{1}-\sigma_{3}\right) \mathrm{x} \varepsilon_{\text {axial }}$, b) $\varepsilon_{\mathrm{v}} \mathrm{x}$ $\varepsilon_{\text {axial. }}$. 
(a)

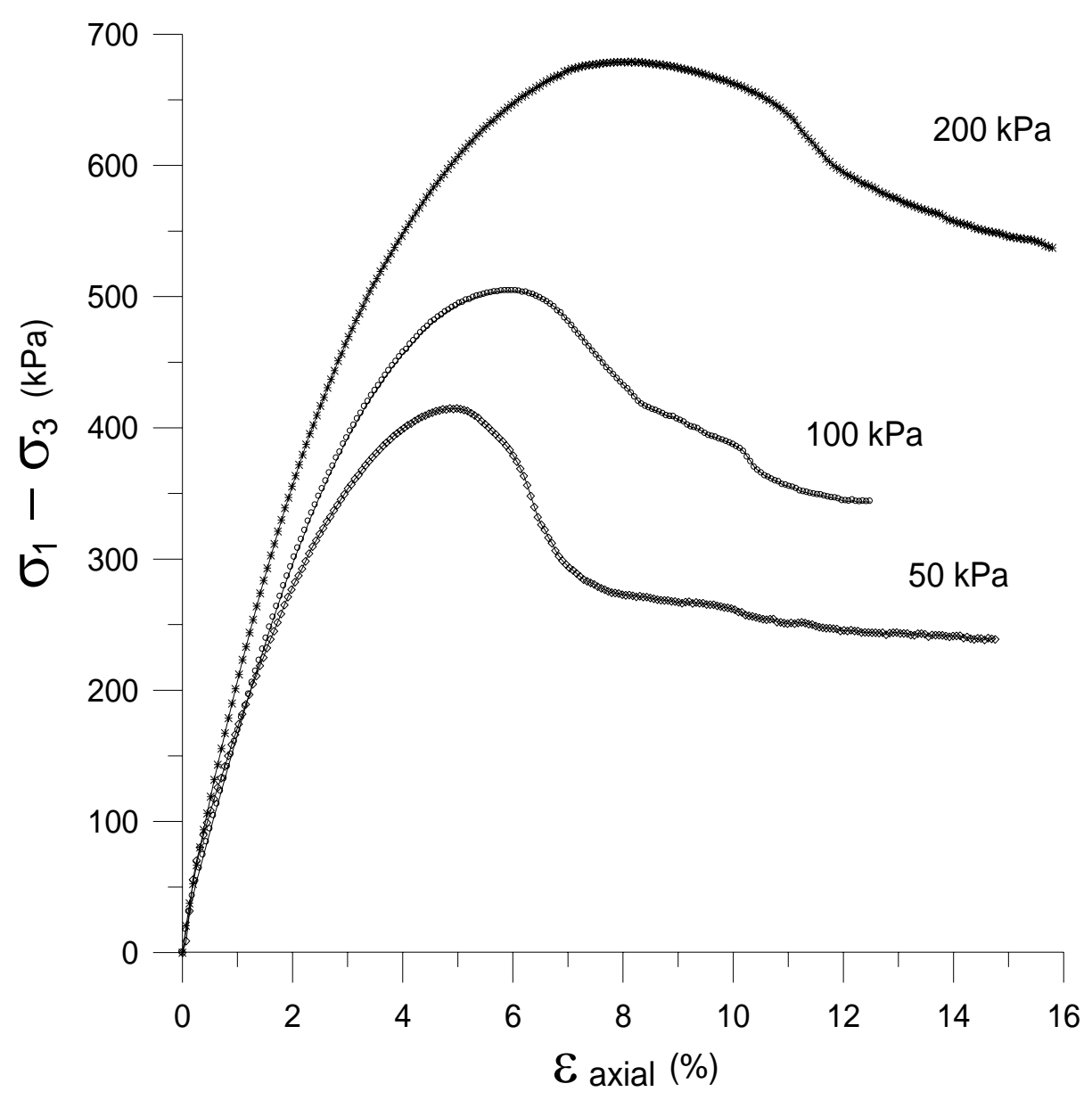

(b)

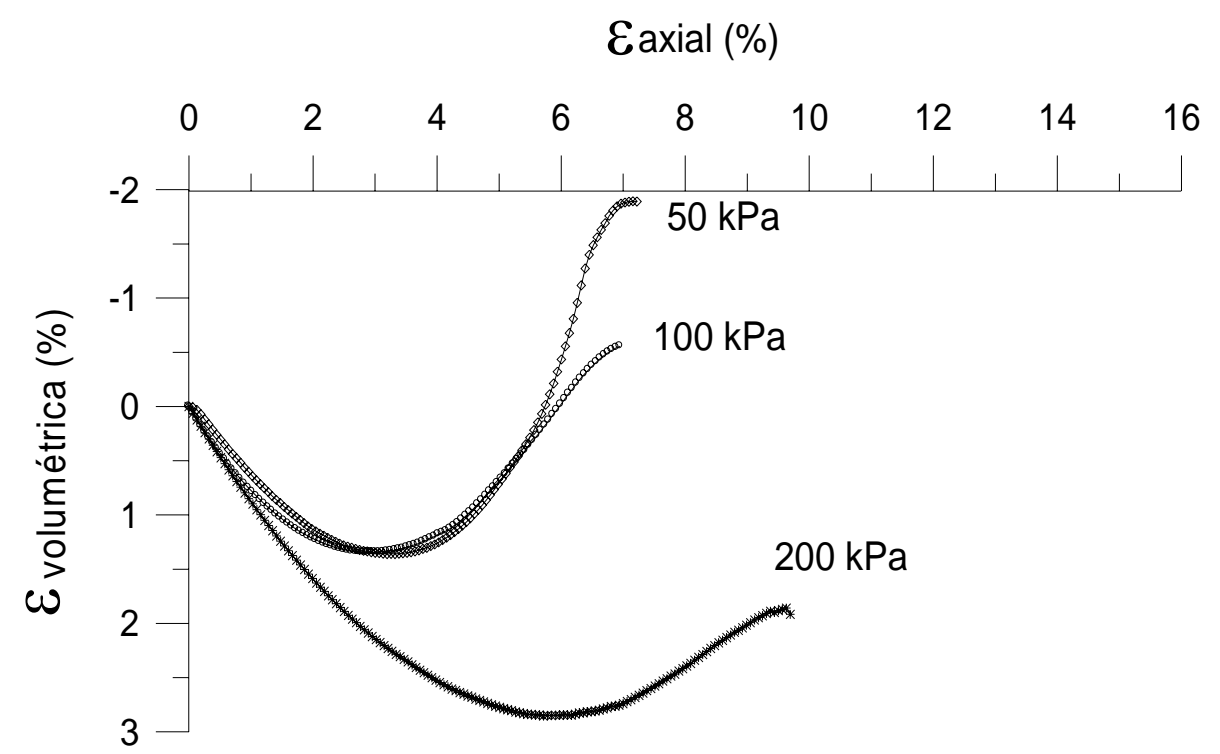

Figura 4.38 - Resultados dos ensaios CID, solo jovem, para $\mathrm{u}_{\mathrm{a}}-\mathrm{u}_{\mathrm{w}}=320 \mathrm{kPa}$ : a) $\left(\sigma_{1}-\sigma_{3}\right) \mathrm{x} \varepsilon_{\text {axial }}$, b) $\varepsilon_{\mathrm{v}} \mathrm{x}$ $\varepsilon_{\text {axial}}$. 
(a)

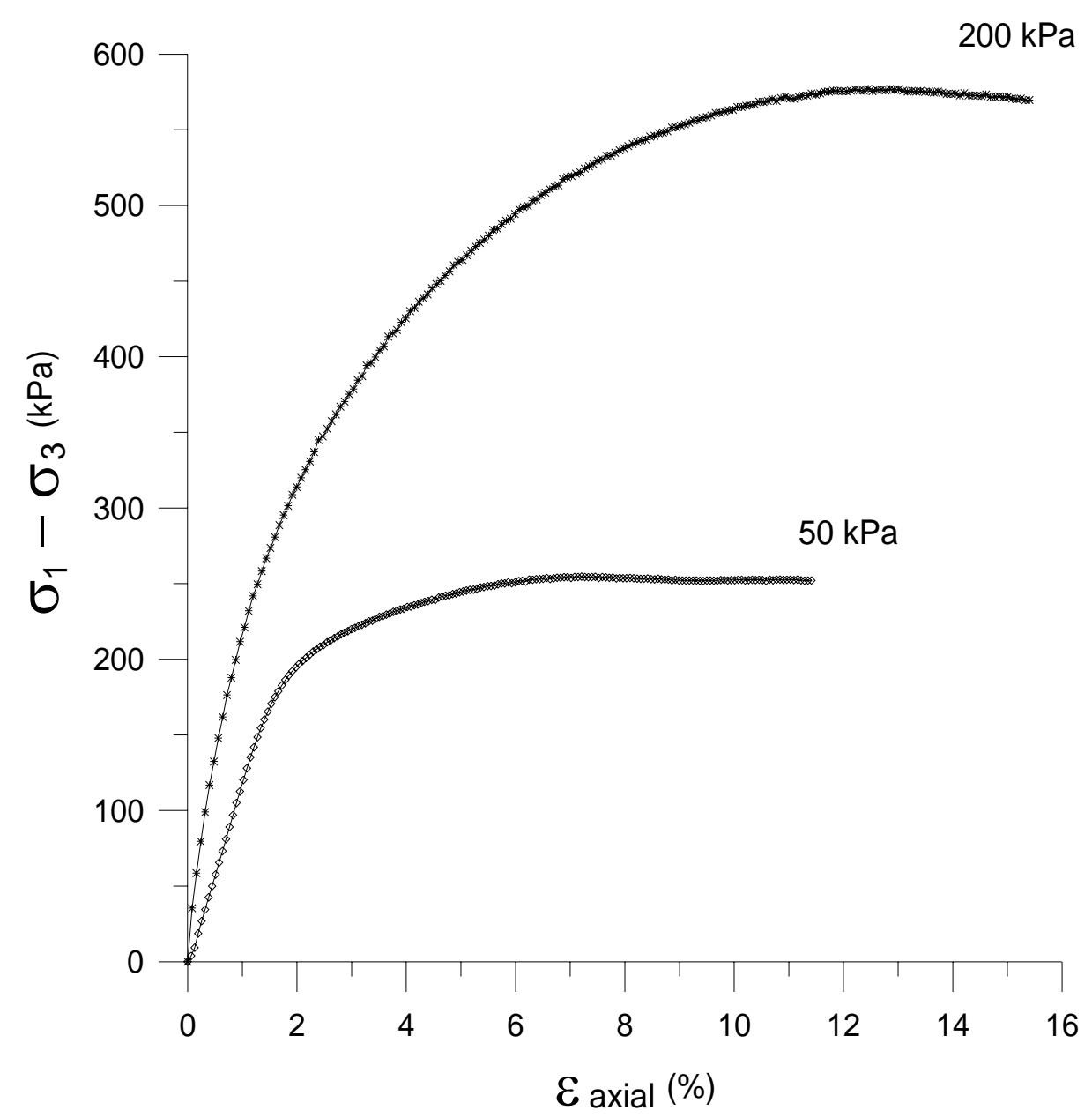

(b)

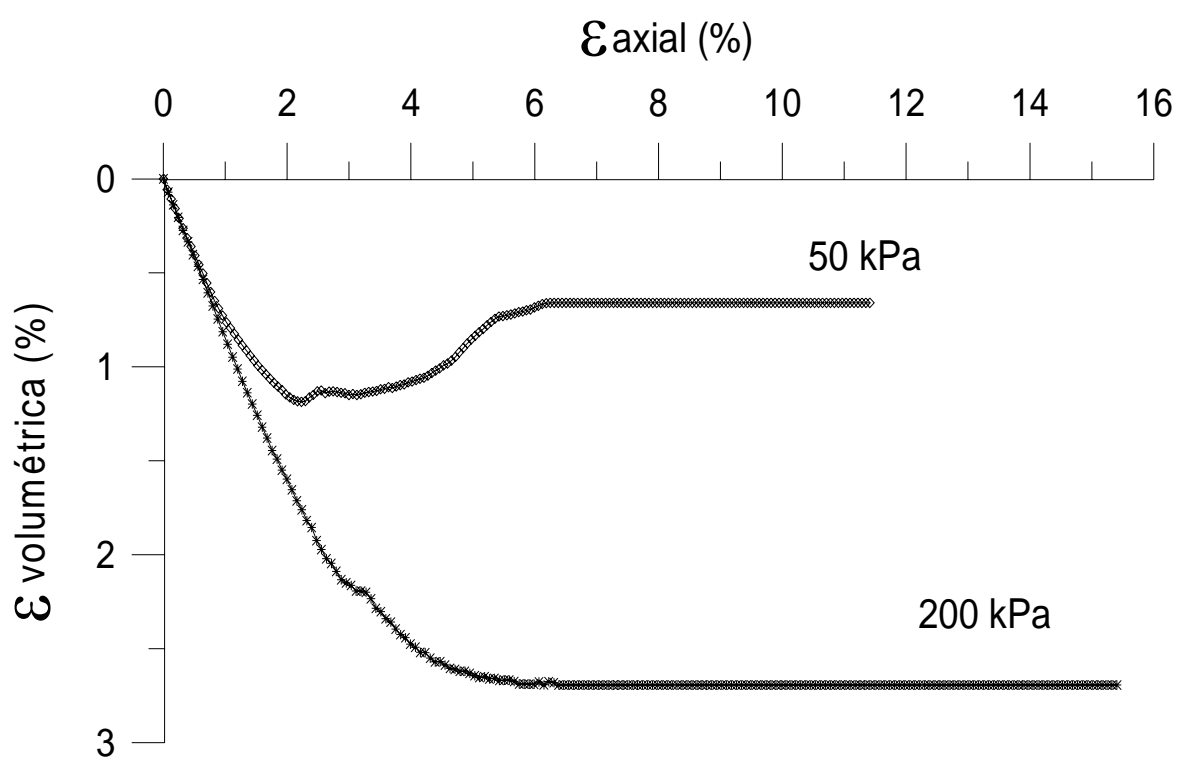

Figura 4.39 - Resultados dos ensaios CID, solo maduro, para $\mathrm{u}_{\mathrm{a}}-\mathrm{u}_{\mathrm{w}}=40 \mathrm{kPa}$ : a) $\left(\sigma_{1}-\sigma_{3}\right) \times \varepsilon_{\text {axial }}$, b) $\varepsilon_{\mathrm{v}} \mathrm{x}$ $\varepsilon_{\text {axial}}$. 
(a)

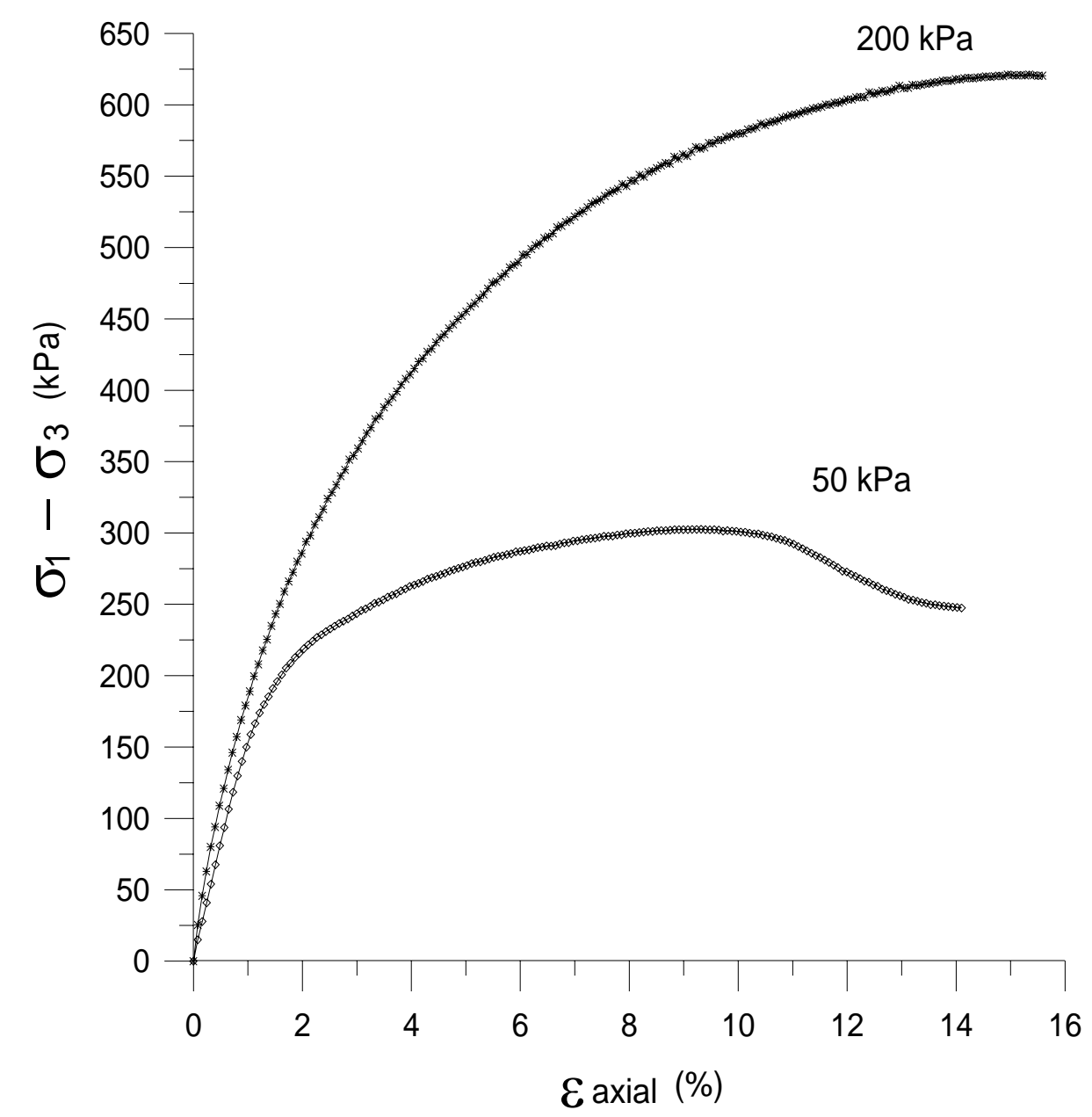

(b)

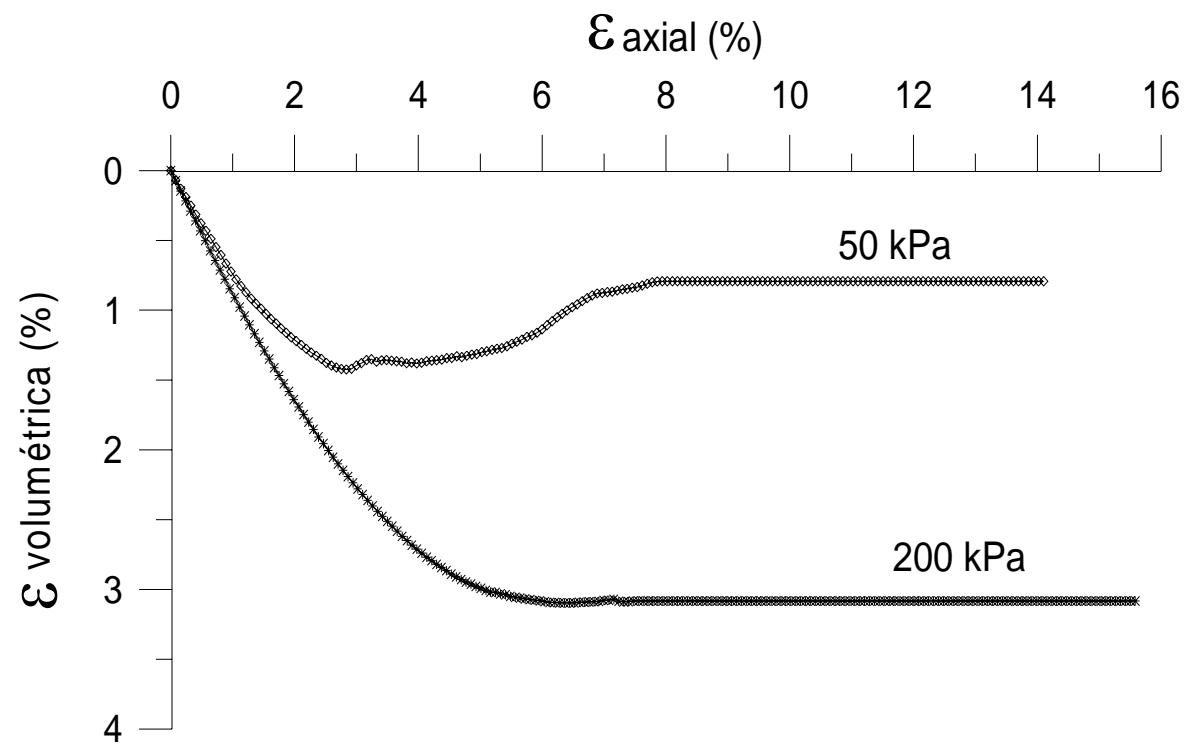

Figura 4.40 - Resultados dos ensaios CID, solo maduro, para $\mathrm{u}_{\mathrm{a}}-\mathrm{u}_{\mathrm{w}}=80 \mathrm{kPa}$ : a) $\left(\sigma_{1}-\sigma_{3}\right) \times \varepsilon_{\text {axial }}$, b) $\varepsilon_{\mathrm{v}} \mathrm{x}$ $\varepsilon_{\text {axial. }}$. 
(a)

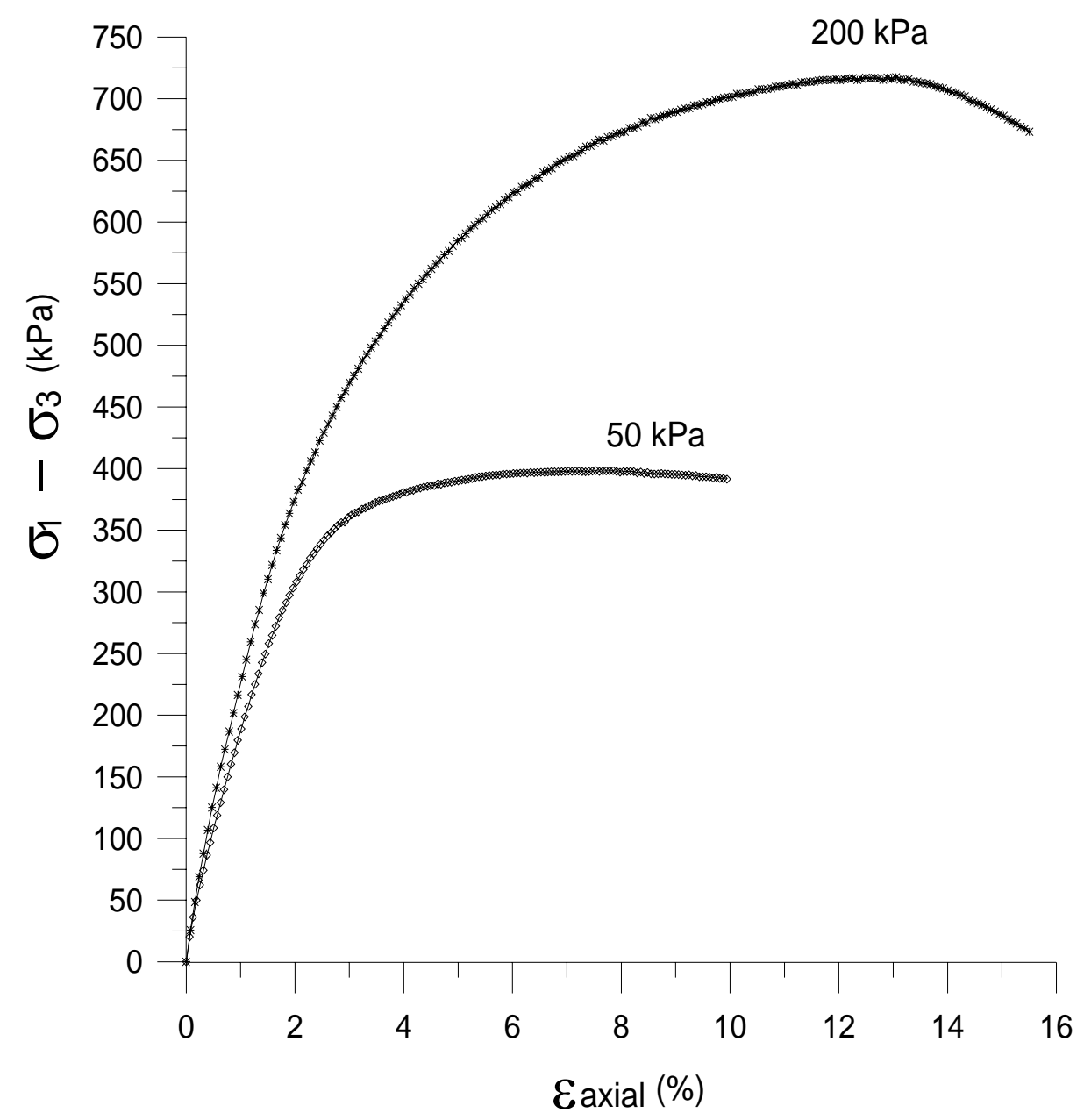

(b)

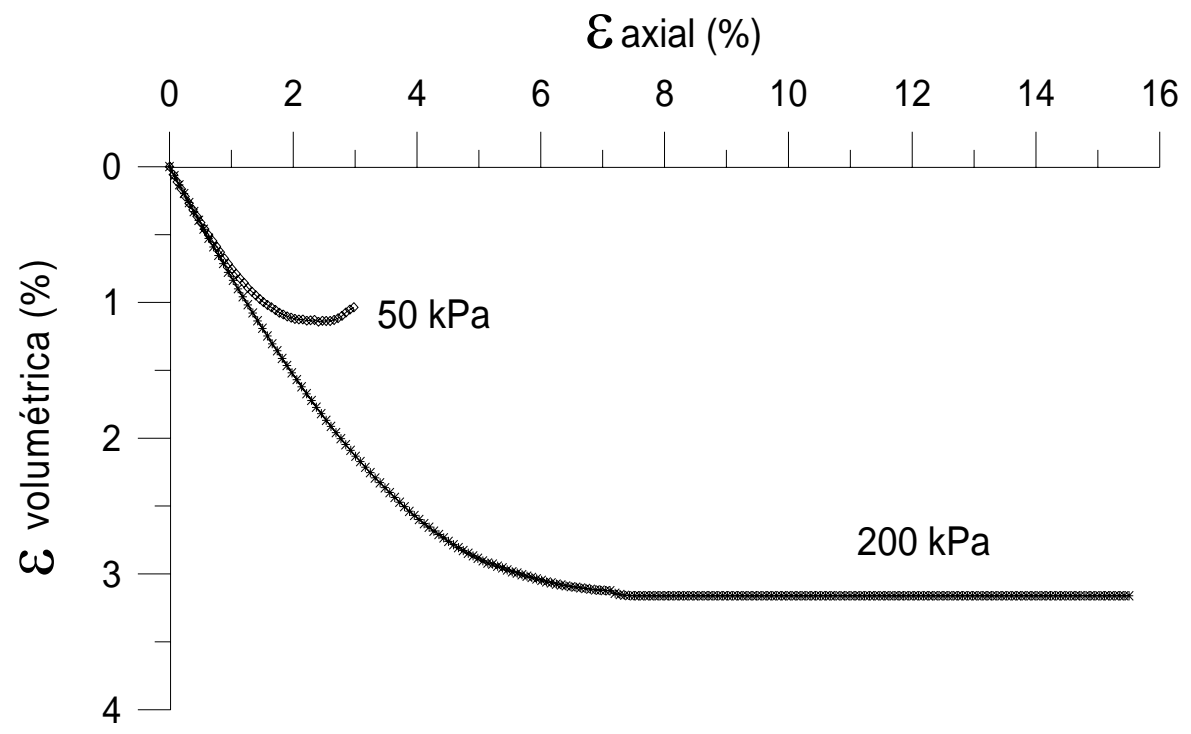

Figura 4.41 - Resultados dos ensaios CID, solo maduro, para $\mathrm{u}_{\mathrm{a}}-\mathrm{u}_{\mathrm{w}}=160 \mathrm{kPa}$ a) $\left(\sigma_{1}-\sigma_{3}\right) \mathrm{x} \varepsilon_{\text {axial }}$, b) $\varepsilon_{\mathrm{v}} \mathrm{x}$ $\varepsilon_{\text {axial. }}$. 
(a)

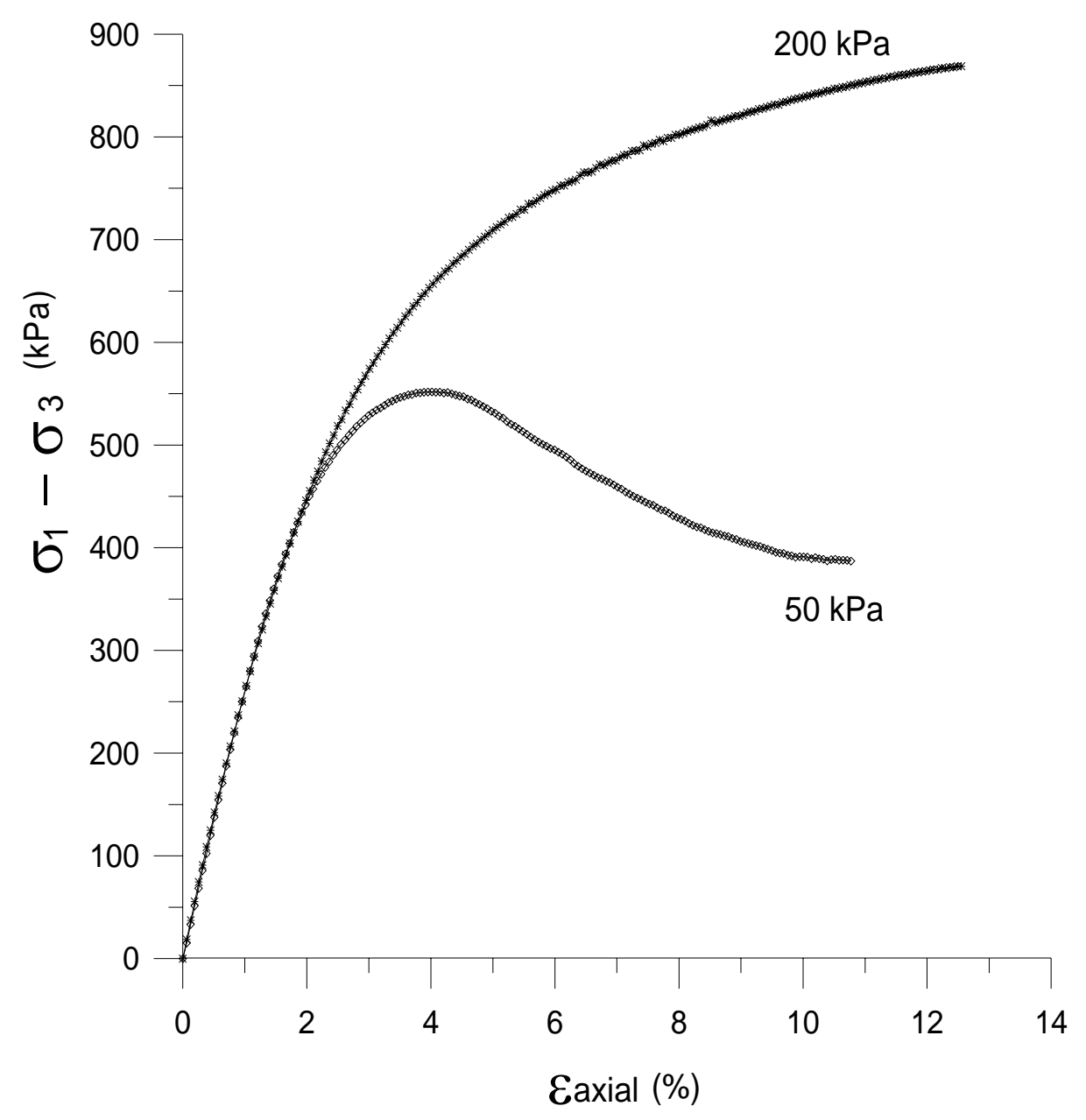

(b)

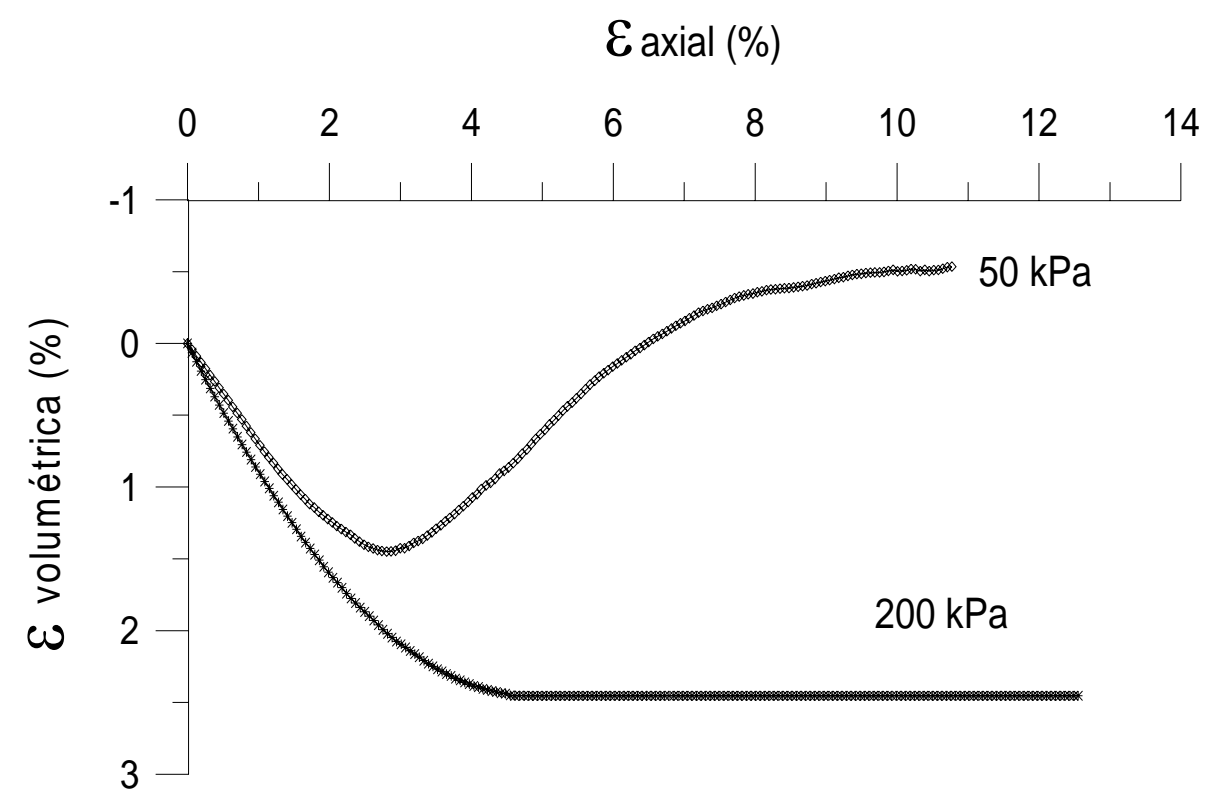

Figura 4.42 - Resultados dos ensaios CID, solo maduro, para $\mathrm{u}_{\mathrm{a}}-\mathrm{u}_{\mathrm{w}}=320 \mathrm{kPa}$ a $)\left(\sigma_{1}-\sigma_{3}\right) \mathrm{x} \varepsilon_{\mathrm{axial}}$, b) $\varepsilon_{\mathrm{v}} \mathrm{x}$ $\varepsilon_{\text {axial }}$. 
Nas Figuras 4.43 e 4.44 mostram-se os resultados dos ensaios de compressão hidrostática realizados, respectivamente, nos solos jovem e maduro, para sucções entre $0 \mathrm{kPa}$ e $320 \mathrm{kPa}$.

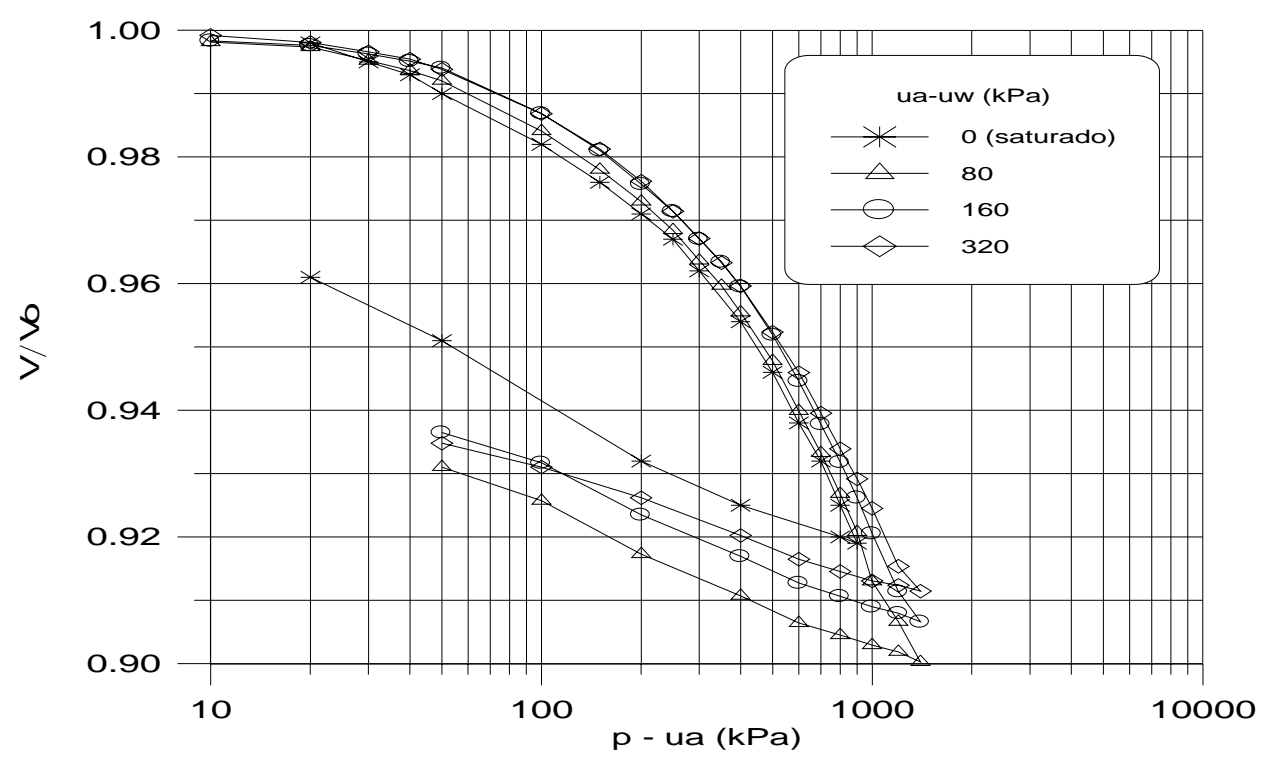

Figura 4.43 - Resultados dos ensaios de compressão hidrostática, para diferentes sucções, realizados no solo jovem.

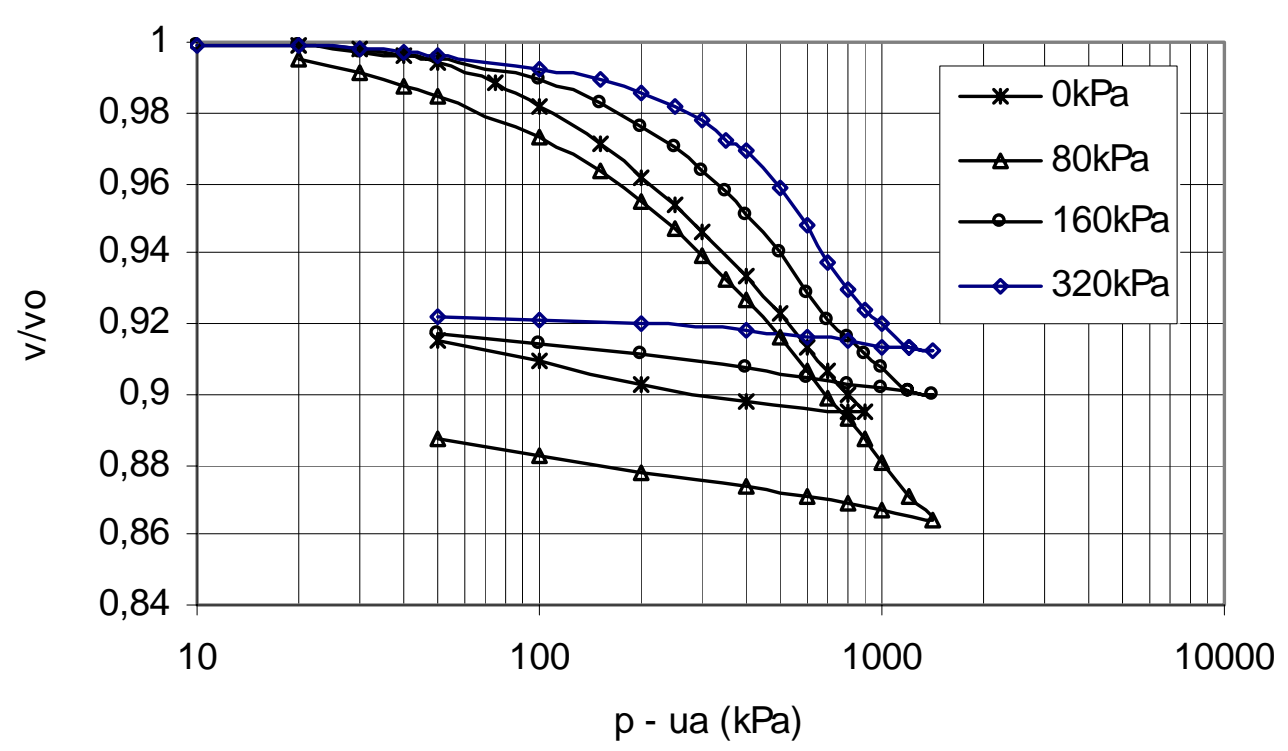

Figura 4.44 - Resultados dos ensaios de compressão hidrostática, para diferentes sucções, realizados no solo maduro. 


\subsubsection{Amostras não saturadas secas ao ar}

A Figuras 4.45 mostra os resultados dos ensaios triaxiais realizados, no solo jovem.

(a)

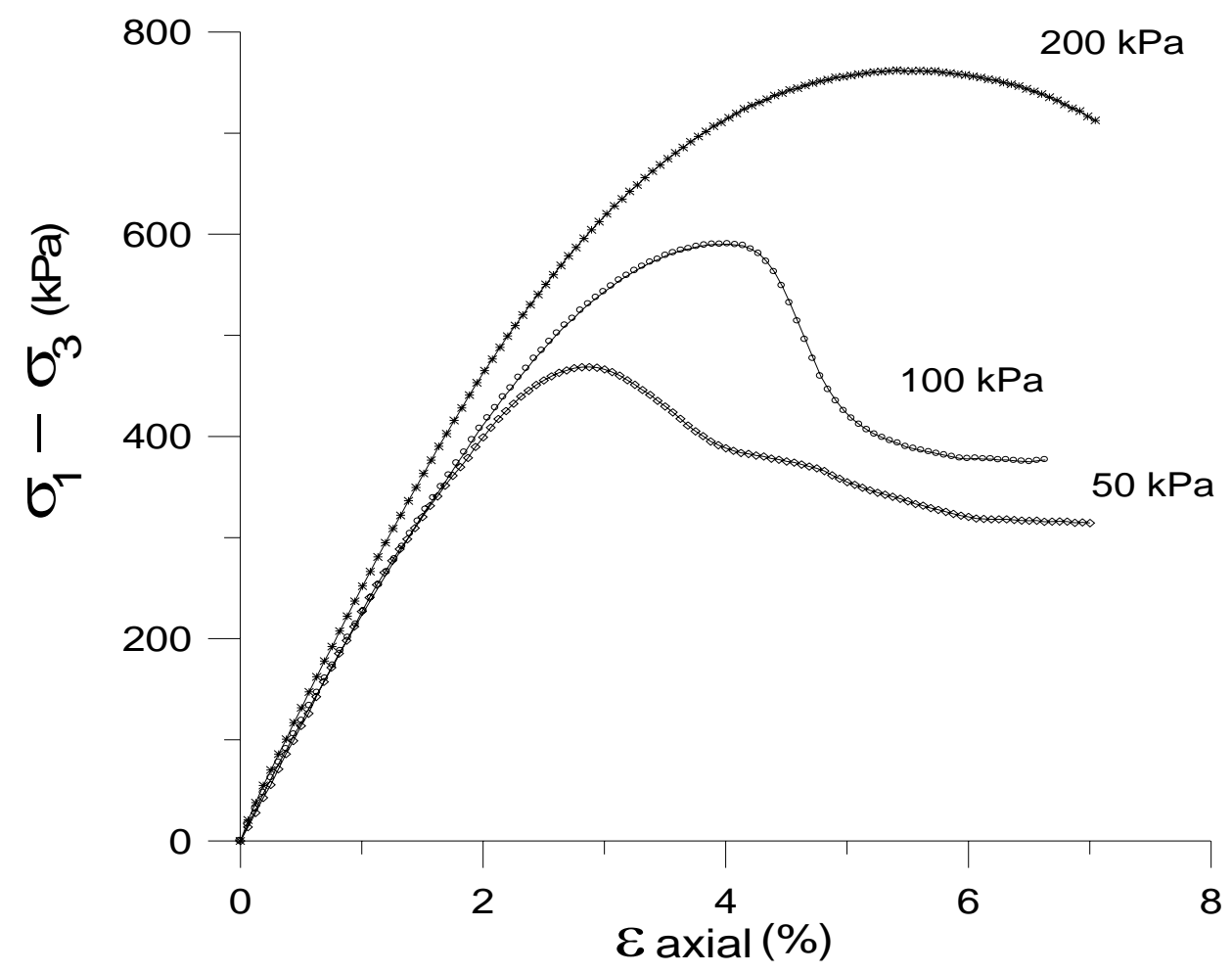

(b)

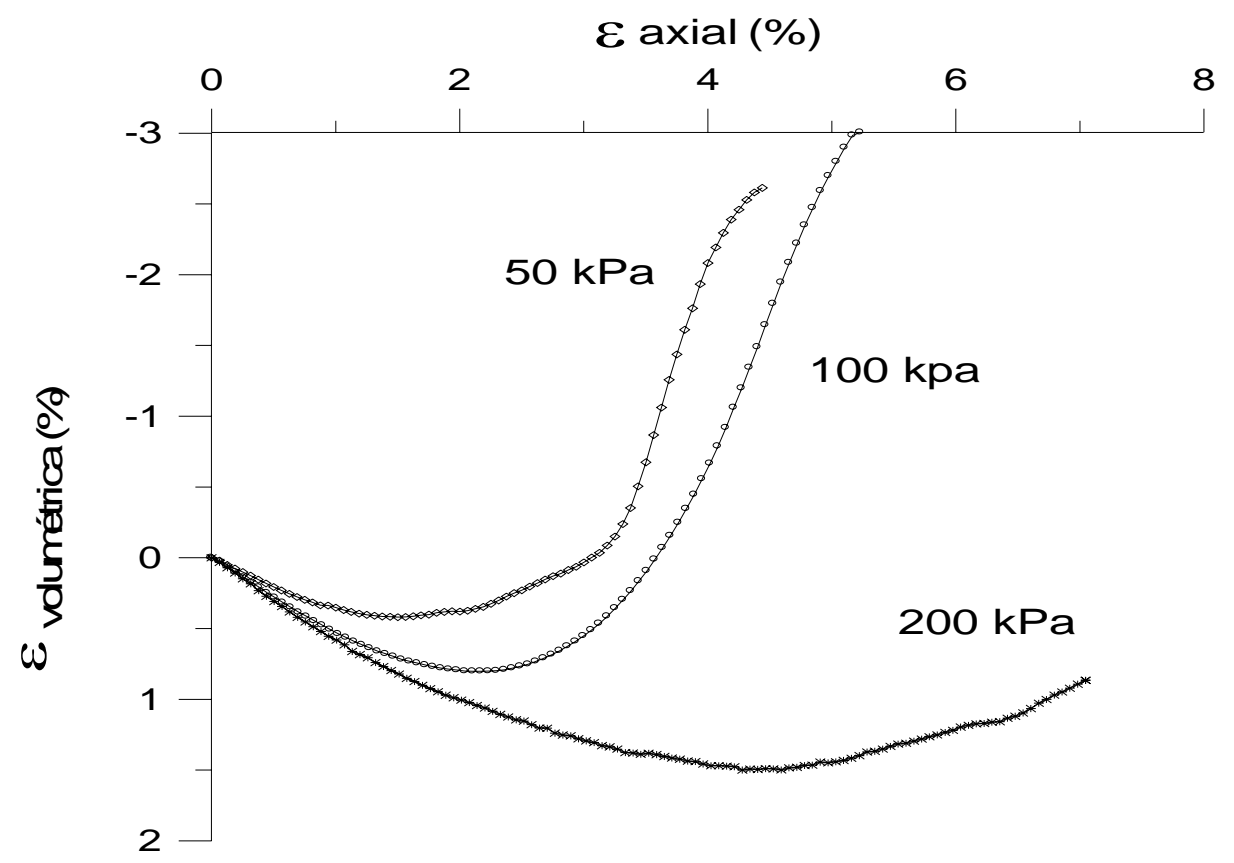

Figura 4.45 - Resultados dos ensaios CID, solo jovem, para amostras secas ao ar: : a) $\left(\sigma_{1}-\sigma_{3}\right) \mathrm{x} \varepsilon_{\mathrm{axial}}$, b) $\varepsilon_{\mathrm{v}}$ $\mathrm{x} \varepsilon_{\text {axial }}$. 


\section{ANÁLISES DOS RESULTADOS}

Inicialmente são discutidos os resultados dos ensaios de caracterização mineralógica, classificação MCT, porosimétrica e micromorfológica. Posteriormente descreve-se o comportamento observado, nas curvas tensão versus deformação axial e deformação axial versus deformação volumétrica, para os dois solos em condições saturadas e não saturadas, com controle de sucção. Em seguida procede-se às analises de resistência e deformabilidade. Nas análises em amostras saturadas verifica-se em especial o efeito da direção de carregamento (anisotropia) no comportamento dos dois solos e utilizam-se as descrições micromorfológicas para explicar o comportamento mecânico obtido. Nas análises em amostras não saturadas, inicialmente obtêm-se a forma de variação do intercepto de coesão e do ângulo de atrito com a sucção e posteriormente faz-se uma previsão da envoltória da resistência não saturada, baseada na proposta de Vilar (2003), a qual é apresentada no trabalho, que utiliza somente um conjunto de ensaios em corpos de prova saturados e outro conjunto com corpos de provas secos ao ar. Apresentam-se as curvas de plastificação obtidas na condição saturada e não saturada, para o solo jovem, e verifica-se a eficiência dos modelos CamClay e de Alonso et al (1990) na representação dos resultados obtidos, respectivamente, para o solo na condição saturada e não saturada. Apresenta-se também um procedimento, baseado na teoria da elasticidade e plasticidade e em pontos com o mesmo trabalho plástico (Lade \& Kim, 1988) para obtenção das demais curvas de plastificação até a ruptura.

\subsection{Ensaios de caracterização}

\subsubsection{Classificação MCT (Miniatura, Compactado, Tropical)}

Pela sua abrangência e alcance técnico, cresce dia-a-dia a importância de se divulgar e aplicar a Metodologia MCT aos solos brasileiros, devendo-se lembrar que ela 
foi concebida, inicialmente, para a classificação e caracterização de solos para aplicações em rodovias e que, há pouco anos, sugeriu-se a sua aplicação de forma generalizada em Geotecnia (COZZOLINO \& NOGAMI, 1993). Esta classificação permite conhecer se o solo apresenta comportamento laterítico ou não. Estes foram os motivos para a incorporação, ao presente trabalho, da metodologia MCT.

A classificação MCT é obtida mediante o uso do ábaco da Figura 4.18, agrupando os solos tropicais de acordo com o seu comportamento no estado compactado, em duas classes principais: solos de comportamento laterítico (L) e solos de comportamento não Laterítico $(\mathrm{N})$. Os solos de comportamento laterítico são subdivididos em três subgrupos: areias lateríticas (LA), solos arenosos lateríticos (LA') e solos argilosos lateríticos (LG'), enquanto os de comportamento não-laterítico são subdivididos em quatro subgrupos: areias não lateríticas (NA), solos arenosos não lateríticos (NA'), solos siltosos não-lateríticos (NS') e solos argilosos não lateríticos (NG').

Os solos são classificados através de dois índices: (1) c’, que é obtido do ensaio mini-MCV e traduz o caráter argiloso do solo em análise; (2) e’, que expressa o caráter laterítico do solo e é calculado mediante o uso da seguinte expressão: e' = (Pi / $100+$ $\left.20 / d^{\prime}\right)^{1 / 3}$. A raiz cúbica foi adotada a fim de que a área ocupada pelos solos de comportamento laterítico fosse equivalente à dos solos de comportamento não-laterítico.

Quanto aos resultados das análises efetuadas, as classes de solos MCT, bem como os seus índices classificatórios estão apresentados na Tabela 5.1.

Tabela 5.1 Índices classificatórios e classes MCT

\begin{tabular}{cccccc}
\hline Solos & índice c’ & índice d' & índice PI & índice e’ & Classe MCT \\
\hline Maduro & 2 & 40 & 0 & 0,79 & LG' \\
Jovem & 1,2 & 3,72 & 280 & 2,01 & NS' \\
\hline
\end{tabular}

Pelo exame visual e táctil dos solos, principalmente no teste em que se coloca um torrão de solo em água, o comportamento laterítico, dado pela gênese do material, é de fácil identificação no Latossolo Vermelho Amarelo (residual maduro), que é 
classificado segundo a Metodologia MCT como pertencente ao grupo LG', laterítico argiloso.

Quanto ao solo residual saprolítico, o caráter não-laterítico está bem evidenciado, pois ele se posiciona na região do grupo NS', solo não-laterítico siltoso.

\subsubsection{Caracterização Mineralógica}

Ao observar os difratogramas do horizonte C (Figura 4.4) para areia grossa, areia fina e argila, nota-se que o quartzo é o mineral predominante nas areias, mas na areia fina já aparecem pequenas reflexões características das micas. Na argila aparecem reflexões de picos de caulinita, que é o mineral predominante e a mica novamente aparece agora em quantidade maior. Além disso, observa-se uma série de reflexões que só podem ser melhor analisadas ao se expandir o difratograma, o que é mostrado na Figura 4.5. Pode-se notar nesse horizonte a presença de mica, mas também da goethita e da hematita que não apareciam claramente.

No difratograma conjunto para o horizonte B, Figura 4.2, se observa apenas o quartzo nas frações areia o que já aponta para maior intensidade de intemperismo atuando nesse horizonte. Na fração argila nota-se claramente a caulinita que continua sendo o mineral predominante e a presença de alguns picos que podem ser melhor discutidos na Figura 4.3 expandida. Observa-se a ausência da reflexão da mica, mas o aparecimento de uma reflexão característica dos VHE (vermiculita com hidróxidos entre camadas) que são formados a partir da degradação da mica. Observa-se também o aparecimento de relexões da gibbsita que é mineral formado a partir da degradação da caulinita e a presença da goethita em conjunto com o desaparecimento da hematita. A goethita nesses sistemas é o óxido de ferro mais estável o que é evidenciado pela coloração bem amarela típica desse horizonte.

Em suma, não parece existir muita dúvida do relacionamento genético desses dois horizontes em função das suas composições mineralógicas.

\subsubsection{Caracterização Micromorfológica}

Do ponto de vista micromorfológico, os contituintes de um solo são de dois tipos: os grãos de esqueleto e o plasma. Os grãos de esqueleto, correspondente às partículas mais grossas, são habitualmente considerados inertes e não deformáveis, enquanto o plasma, de tamanho coloidal, representa a fração argilosa que é mais mobilizável e sujeita a rearranjos por efeito de pressões hídricas e mecânicas. No estudo 
micromorfológico, se faz inicialmente o reconhecimento dos tipos de plasma e dos tipos de distribuição relativa do plasma em relação aos grãos de esqueleto. Reconhece-se igualmente o tamanho, a forma e o rearranjo dos agregados e dos vazios que os separam. Os arranjos estruturais decorrentes da organização do plasma podem ser observados com ajuda de microscópio petrográfico ótico sobre lâminas delgadas fabricadas a partir de materiais endurecidos e, ou, utilizando-se o microscópio eletrônico de varredura. Em solos brasileiros, um volume muito expressivo de informações sobre as propriedades físicas de relevância geotécnica é conhecido, enquanto certas características morfológicas e microestruturais que também podem ser relacionadas ao comportamento geotécnico raramente são quantificadas ou mesmo observadas (SCHAEFER, 1996; SCHAEFER ET AL., 1996). De fato, não se conhece as características diagnósticas, em nível microscópico, de problemas como reorganização da estrutura, dinâmica da porosidade total, compactação, que poderiam fornecer subsídios ao conhecimento geotécnico dos solos. Assim, estudos detalhados da natureza microestrutural de solos brasileiros se fazem necessários. Nesse contexto, parte do trabalho teve por objetivo caracterizar micromorfologicamente uma amostra de solo superficial (horizonte B) e outra de saprolito (horizonte C), ambas no estado natural, com intuito de tentar explicar o comportamento mecânico obtido através dos ensaios triaxiais realizados.

\subsubsection{Solo Maduro (Latossolo Vermelho-Amarelo)}

É um solo de grande expressão territorial na Zona da Mata de Minas Gerais e apresenta horizonte B latossólico de tonalidade vermelho-amarela, estrutura bem desenvolvida, em blocos bem individualizados que se desfaz em muito pequena granular forte, aspecto bastante poroso, com aproximadamente $40 \%$ de porosidade visual. A textura é de uma argila arenosa.

Na amostra estudada, as feições da microestrutura observadas são características dos Latossolos Vermelho-Amarelos de Viçosa, com grão de esqueleto quartzoso com microagregação ovóide forte, algo coalecida, com contato face-a-face, em virtude da natureza caulinítica da fração argila destes solos (Nunes et al., 2000). Os grãos são quase exclusivamente de quartzo (Qz) ou nódulos de ferro e minerais de titânio, como visto na análise mineralógica. O plasma é formado por um conjunto fortemente isotrópico, cimentado, fino, de aspecto floculado, de tonalidade vermelho-amarela com pontuações vermelho-escuras e pretas. Os vazios são bem visíveis e estão 
compreendidos entre os microagregados e interligados entre si. Em certas partes da amostra do solo LV, nota-se uma tendência nítida ao empacotamento e certa coalescência dos microagregados ovóides, tornando o material mais coeso. O efeito da compactação nesse material, em uma primeira visão, parece ser benéfico. As Figuras 4.20 a 4.23 mostram fotomicrografias das microestruturas típicas observadas no solo maduro em diferentes campos da lâmina. Na foto 4.21, a amostra revela forte microestruturação granular, tonalidades vermelho-amarelas, abundantes carvões, nódulos ferruginosos, vazios interligados e também apresentando teores de ferro cimentante elevados. Na foto 4.22 a amostra evidencia certa soldagem (coalescência) dos microagegados de forma ovóide, na sua parte mais compacta, além disto esta foto sugere que a compactação seria aumentada se o solo fosse mecanicamente compactado. Na figura 4.23 tem-se uma fotomicrografia mostrando a ligação entre os diversos blocos de microagregados.

\subsubsection{Solo Jovem (Solo Saprolítico)}

É um material de solo do horizonte C, sem qualquer estrutura evidente, resultante de um perfil de intemperismo desenvolvido de gnaisse do Pré-Cambriano, com camadas de espessuras superiores a 15 metros. Apresenta alternância de bandas micáceas e cauliníticas, estas últimas formadas da decomposição de feldspatos, além de quartzo residual disperso; A mica se encontra fortemente alterada e caulinizada, com um tom róseo avermelhado, devido à presença de hematita, formando grandes flocos sanfonados. A porosidade é acentuada, em torno de $30 \%$. A textura é de uma areia siltosa. Em outras partes, apresenta coloração mais acinzentada, com pouca presença de óxidos de ferro, prevalecendo caulinita em flocos e mica, com a mesma textura, contudo com maior quantidade de areia fina.

A Figura 4.24, em luz plana, ilustra o material em escala microscópica. A Figura 4.25, em luz polarizada, ilustra a zona mais densificada de pseudomorfos de biotitas alteradas em caulinita de grande tamanho de cristal (“o arranjo estrutural” é basicamente destes pseudomorfos). Estes pseudomorfos estão dispersos, de maneira caótica, no solo saprolítico natural; Nas zonas onde há maior presença de pseudomorfos, e conseqüentemente maior orientação, podem formar superfícies de fraqueza, geradas possivelmente pela expansão / contração diferenciada dos pseudomorfos cauliníticos, em relação ao plasma e aos grãos de areia do esqueleto do solo. Esta disposição 
preferencial dos pseudomorfos formando zonas orientadas, que poderiam favorecer a formação de planos e linhas de fraqueza, pode ter repercussões importantes, do ponto de vista geotécnico. O ferro proveniente do intemperismo da biotita dá uma coloração avermelhada nas bordas dos pseudomorfos (Figura 4.24), mas fraca cimentação, com estrutura do tipo sanfonada. Este ferro $\left(\mathrm{Fe}^{3+}\right)$ que migra e precipita na borda dos pseudomorfos permite uma fraca cimentação do solo saprolítico, dando pouca estabilidade estrutural ao material. O efeito da compactação nesse material pode aumentar a cimentação natural da microestrutura, com possíveis efeitos benéficos da compactação neste solo, pela reorientação e compactação dos pseudomorfos.

\subsubsection{Comparação entre os dois solos}

Das análises microestruturais, percebe-se claramente que os dois solos apresentam microestruturas diferentes e que por causa destas distintas microestruturas pode-se chegar a comportamentos mecânicos diferenciados quando se estuda a anisotropia, por exemplo.

O solo maduro apresenta uma microestrutura comandada pelos microagregados ovóides cimentados, característica dos Latossolos Vermelho-Amarelos de Viçosa, muito propícia a rearranjos microestruturais, conforme visto nas fotomicrografias comentadas anteriormente, e que se mostra heterogênea e anisotrópica como um todo.

O solo jovem apresenta uma microestrutura comandada pelos pseudomorfos de biotita. Estes são altamente compressíveis, de uma maneira praticamente similar independente da direção de carregamento, e estão dispersos no solo de uma forma caótica sugerindo assim um material sem estruturação significante no nível de microestrutura. Esta microestrutura, baseada nas características dos pseudomorfos, parece ser muito mais homogênea e isotrópica quando comparada com a microestrutura do solo maduro.

Posteriormente, nas análises dos ensaios triaxiais, estas descrições serão confrontadas com os resultados mecânicos com intuito de explicar o comportamento apresentado. 


\subsubsection{Análise porosimétrica}

Neste trabalho utilizou-se a classificação de Webb \& Orr (1997) para a identificação dos macro e mesoporos que considera poros com diâmetro menores que $0.002 \mu \mathrm{m}$ como microporos, de 0,002 a $0,05 \mu \mathrm{m}$ como mesoporos e maiores de $0,05 \mu \mathrm{m}$ como macroporos.

No ensaio o mercúrio é forçado a entrar nos poros da amostra de solo através da aplicação de pressão. Inicialmente ele penetra nos poros entre os grãos e à medida que a pressão vai aumentando ele penetra nos poros intra-grãos. Com este ensaio foram obtidas as curvas de intrusão-extrusão de mercúrio com a pressão aplicada para os dois horizontes (Figuras 4.6 e 4.9). Observa-se que ambas as curvas de extrusão não coincidem com as curvas de intrusão; isto porque as formas irregulares dos poros (formas de pescoço, garrafas) impedem que durante a extrusão todo mercúrio seja extraído do solo, o que ocasiona o aparecimento de histerese.

Nos resultados de porosimetria apresentados para os dois horizontes nota-se que o mercúrio preencheu apenas os macro e mesoporos; os poros menores que 0,002 $\mu \mathrm{m}$ (microporos) não aparecem nas planilhas resultantes dos ensaios.

Nas Figuras 4.8 e 4.11 observa-se o histograma de freqüência, respectivamente, para o solo maduro e jovem.

Para o solo maduro observa-se a presença de duas famílias de poros, sendo que uma apresenta valor de pico bem maior que a outra. A primeira apresenta pico quando o diâmetro dos poros é aproximadamente igual a $0.055 \mu \mathrm{m}$, correspondendo assim ao limite entre os mesoporos e macroporos. A segunda família apresenta pico quando o diâmetro dos poros é aproximadamente igual a $40 \mu \mathrm{m}$, correspondendo assim à classe dos macroporos.

Para o solo jovem observa-se também a presença de duas famílias de poros onde uma das famílias apresenta valor de pico maior que a outra. A primeira apresenta pico quando o diâmetro dos poros é aproximadamente igual a 0,9 $\mu \mathrm{m}$, correspondendo à classe dos macroporos. A segunda apresenta pico quando o diâmetro dos poros é aproximadamente igual a $10 \mu \mathrm{m}$, correspondendo também à classe dos macroporos.

Para ambos os solo verificou-se o predomínio, principalmente no solo jovem, dos macroporos. 


\subsection{Análises dos resultados Triaxiais}

\subsubsection{Discussão das Curvas Tensão deformação obtidas dos ensaios realizados}

Neste ítem descreve-se o comportamento observado, nas curvas tensão versus deformação axial e deformação axial versus deformação volumétrica, para os dois solos em condições saturadas e não saturadas com controle de sucção.

\subsubsection{Amostras saturadas}

A forma das curvas tensão deformação (relação entre deformação axial e diferença de tensões principais) apresentou-se como função do nível de tensões no ensaio e do nível de cimentação presente. Para os ensaios triaxiais em ambos os solos foi possível distinguir dois tipos de comportamento em função do nível de tensões confinantes. O primeiro tipo (A), comum no solo jovem, caracteriza-se por uma relação praticamente linear entre tensão e deformação quase até um bem definido pico de resistência, que ocorre para deformações axiais não superiores a $5 \%$. As variações de volume durante o cisalhamento, neste caso, consistem em moderadas contrações (não maiores do que $1,5 \%$ e, em alguns casos, pequena dilatação. O segundo tipo (B) de comportamento, que ocorre nos dois solos, caracteriza-se por uma curva tensão deformação claramente não linear, na qual a máxima diferença de tensões só se define para deformações axiais bem próximas ou maiores do que $10 \%$. As deformações volumétricas neste caso são francamente contrativas (contrações maiores do que 1,5 \% e atingindo os $5 \%)$.

Para o solo jovem, observou-se que o comportamento das curvas mencionadas praticamente independe da direção de carregamento. Pode-se identificar o primeiro tipo de comportamento (A) para os resultados dos ensaios onde a tensão confinante é inferior ou igual a $150 \mathrm{kPa}$ e o segundo tipo (B) para os resultados dos ensaios onde a tensão confinante é superior a $250 \mathrm{kPa}$. Para o solo jovem e maduro, a tensão de préadensamento determinada no ensaio de compressão hidrostática é respectivamente, 265 $\mathrm{kPa}$ e $110 \mathrm{kPa}$. Pode-se concluir assim que o comportamento do tipo (A) está associado ao pré-adensamento do solo ( $\sigma_{3}$ menor que a tensão de pré-adensamento do solo) e o comportamento do tipo $(\mathrm{B})$ ao trecho normalmente adensado $\left(\sigma_{3}\right.$ maior que a tensão de pré-adensamento do solo). 
Para o solo maduro observou-se que a direção de carregamento influenciou nas formas das curvas. Para os resultados dos ensaios cisalhados na direção horizontal identificou-se o segundo tipo (B) de comportamento, já para os da direção vertical observou-se um comportamento distinto dos definidos anteriormente e caracterizado por dois trechos com inclinações diferentes: um praticamente linear antes da ruptura e outro mostrando uma curva que se assemelha a dentes de serra. As deformações volumétricas foram contrativas entre $1,5 \%$ e 4,5 \% sem apresentar uma variação definida com a tensão confinante. Este comportamento bem como os outros dois tipos de comportamento podem ser explicados pelo efeito da cimentação que é comum em solos residuais.

Para apreciar o efeito de uma possível cimentação será definida a tensão de cedência e aproveitando os resultados dos ensaios do solo jovem serão discutidos os possíveis tipos de comportamento observados devido a um possível efeito da cimentação. O efeito da cimentação no comportamento mecânico dos solos pode ser observado pelos resultados de ensaios de compressão triaxial ou de compressão edométrica e ou hidrostática. Nestes, quando os resultados são apresentados em gráficos de variação de índices de vazios em função da tensão aplicada, observa-se uma alteração da curva, para um certo nível de tensão, acentuando-se a redução do índice de vazios. Este nível de tensão, que é aquele onde ocorre a ruptura da cimentação do solo, fica ainda mais nítido quando as tensões são expressas em escala logarítmica. Por semelhança ao comportamento das argilas saturadas, esta tensão é chamada de tensão de pré-adensamento. Tal denominação, entretanto, não é adequada, pois o comportamento não é devido a um carregamento prévio que o solo tenha sofrido. Por esta razão, por semelhança, alguns autores usam a expressão "pseudo tensão de pré-adensamento". A denominação de tensão de cedência, entretanto, parece ser mais adequada e vem sendo preferida por autores modernos. Refere-se à tensão em que há uma redução do índice de vazios (cedência), que é fruto de terem sido vencidas as ligações resultantes da cimentação que o solo apresentava. A tensão de cedência do solo jovem foi obtida através da descontinuidade da curva índice de vazios versus tensão, do ensaio de compressão hidrostática, utilizando a escala bilinear proposta por Vaughan (1985). Esta tensão foi determinada também, utilizando-se o procedimento de Pacheco Silva, elaborado para determinar a tensão de pré-adensamento de argilas pré-adensadas. $\mathrm{O}$ valor encontrado, para este solo, não sofreu alteração com o procedimento adotado e seu valor foi de $265 \mathrm{kPa}$. 
Segundo Pinto (2002), três tipos possíveis de comportamento, devido ao efeito da cimentação, podem ocorrer:

1 - quando a tensão confinante é mais baixa, perante a tensão de cedência , a tensão desviadora máxima é atingida com pequena deformação (quando a cimentação é destruída), após o que a tensão desviadora se estabiliza num nível mais baixo.

2 - para uma tensão confinante mais alta, mas ainda abaixo da tensão de cedência, a curva tensão deformação apresenta uma mudança de comportamento quando a cimentação é destruída, havendo, entretanto, uma resistência final com desviadora maior .

3 - para tensões confinantes acima da tensão de cedência, o comportamento do material começa a aproximar-se do comportamento de solos não cimentados, pois o próprio confinamento destruiu a cimentação.

A Figura 5.1, elaborada por Pinto (2002), apresenta estas três situações. A Figura 5.1 (a) indica as curvas tensão deformação, com as características acima descritas e a Figura 5.1 (b) as trajetórias de tensão que definem um campo, delimitado por uma curva de cedência, dentro da qual a cimentação é responsável pelo comportamento e fora do qual a cimentação não mais atua e o comportamento do solo é totalmente devido ao atrito entre as partículas.

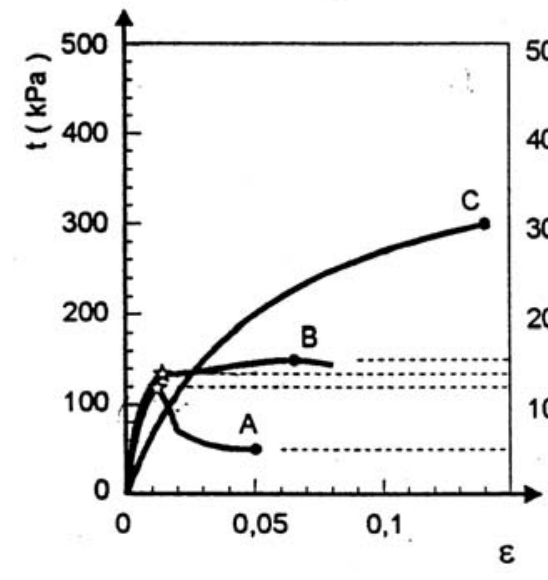

(a)

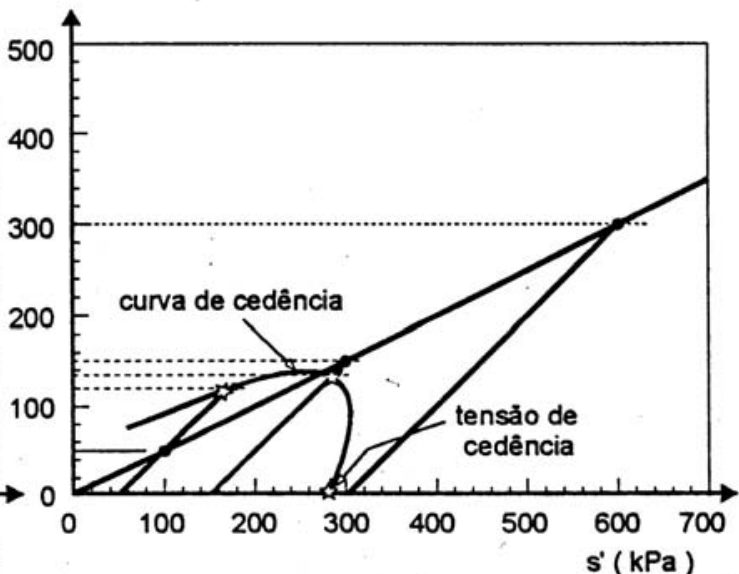

(b)

Figura 5.1 - Efeito da cimentação: (a) curvas tensão-deformação; (b) curva de cedência 
Através das curvas tensão versus deformação axial do solo jovem (Figuras 4.26, $4.27,4.28)$ percebe-se que o comportamento do tipo 2 ocorre para tensão confinante entre 100 e 250, ambas abaixo da tensão de cedência (265 kPa). Nestas figuras percebese que para a tensão entre 100 e $200 \mathrm{kPa}$, principalmente a de $200 \mathrm{kPa}$, a curva tensão deformação apresenta uma mudança de comportamento quando a cimentação é destruída (deformação axial entre 2,5\% e 5\%), havendo, entretanto, uma resistência final com desviadora maior (deformação axial entre 5 e $10 \%$ ). Porém o comportamento do tipo 3 não ocorre nos ensaios realizados.

Para o solo maduro na direção vertical observa-se uma mudança de inclinação bem definida entre dois trechos praticamente lineares, antes da ruptura, e uma ruptura com ondulações parecendo com dentes de serra. Estes dois aspectos podem estar relacionados a um possível processo de quebra de algum tipo de agente cimentante presente ou possíveis rearranjo de sua microestrutura. Para o solo maduro ensaiado na direção horizontal o comportamento observado já é de um material praticamente não cimentado. Esta mudança de comportamento no solo maduro devido a direção de ensaio pode estar associado à alta heterogeneidade deste solo, ao nível de microestrutura conforme relatado anteriormente no item lâminas delgadas, apesar de visivelmente apresentar-se homogêneo.

\subsubsection{Amostras não saturadas com controle de sucção}

As Figuras 5.2 a 5.5 mostram respectivamente o efeito da sucção nas curvas tensão versus deformação axial, no solo jovem e maduro para as tensões confinantes de 50 e $200 \mathrm{kPa}$. 

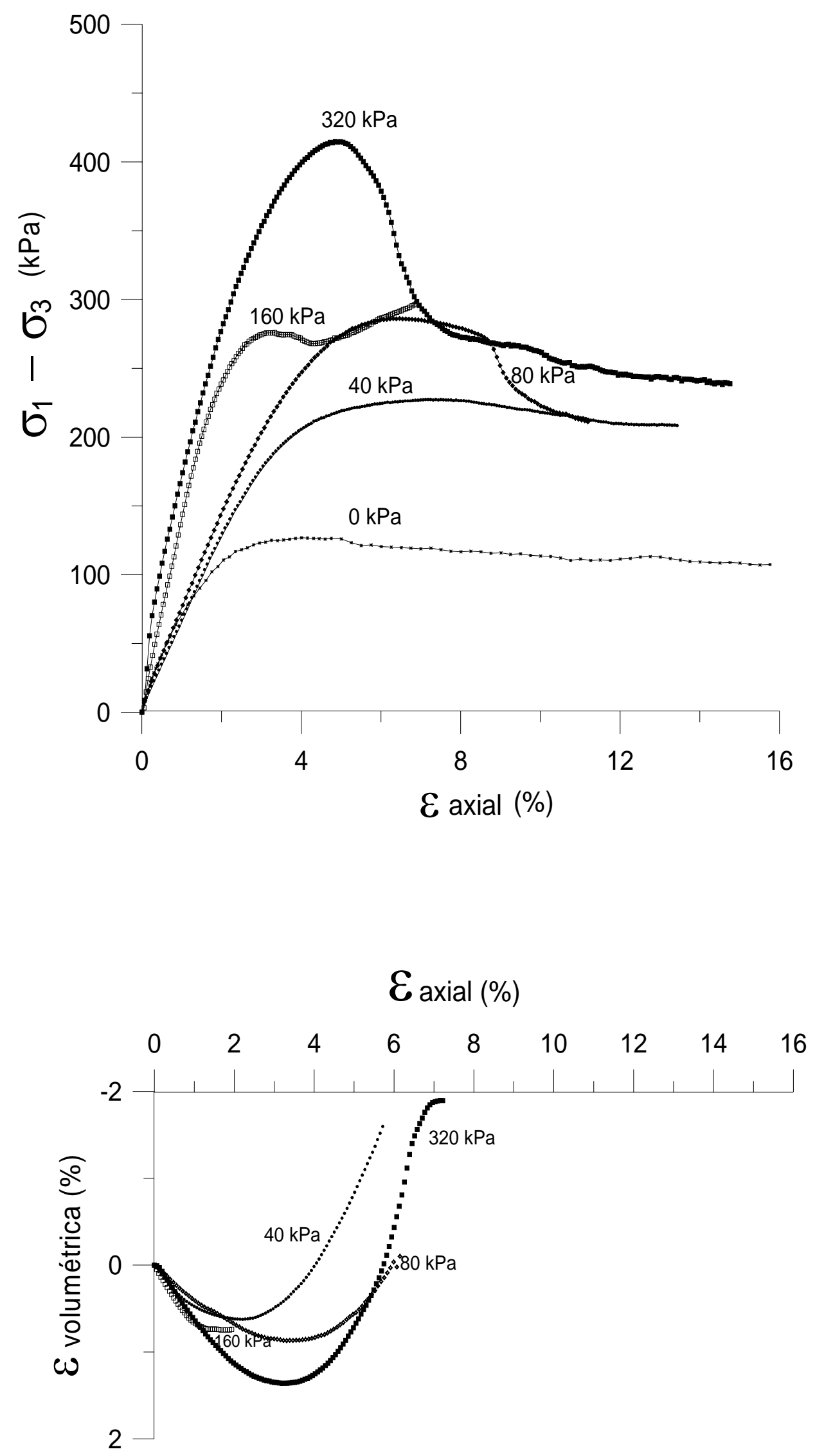

Figura 5.2 - Efeito da sucção na curva tensão versus deformação e deformação axial versus volumétrica solo jovem, para tensão confinante igual a $50 \mathrm{kPa}$. 


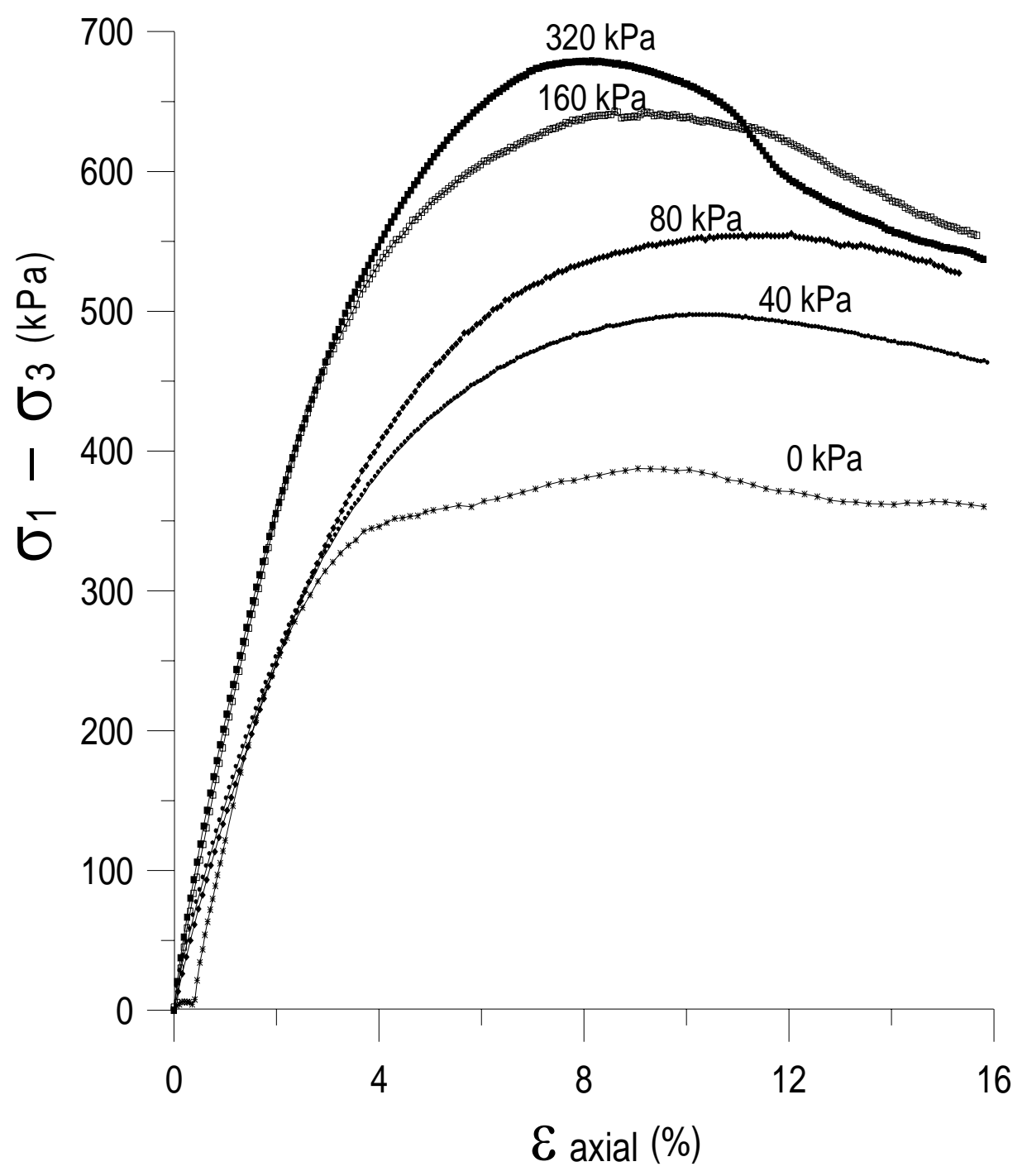

Eaxial (\%)

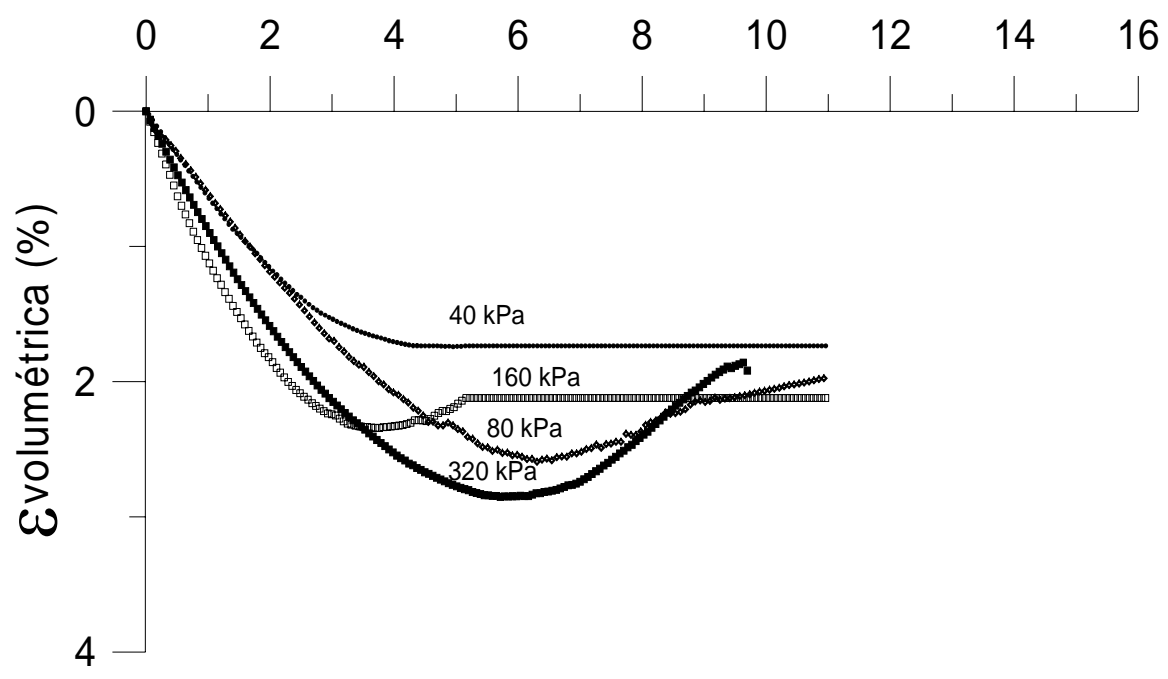

Figura 5.3 - Efeito da sucção na curva tensão versus deformação e deformação axial versus volumétrica solo jovem, para tensão confinante igual a $200 \mathrm{kPa}$. 

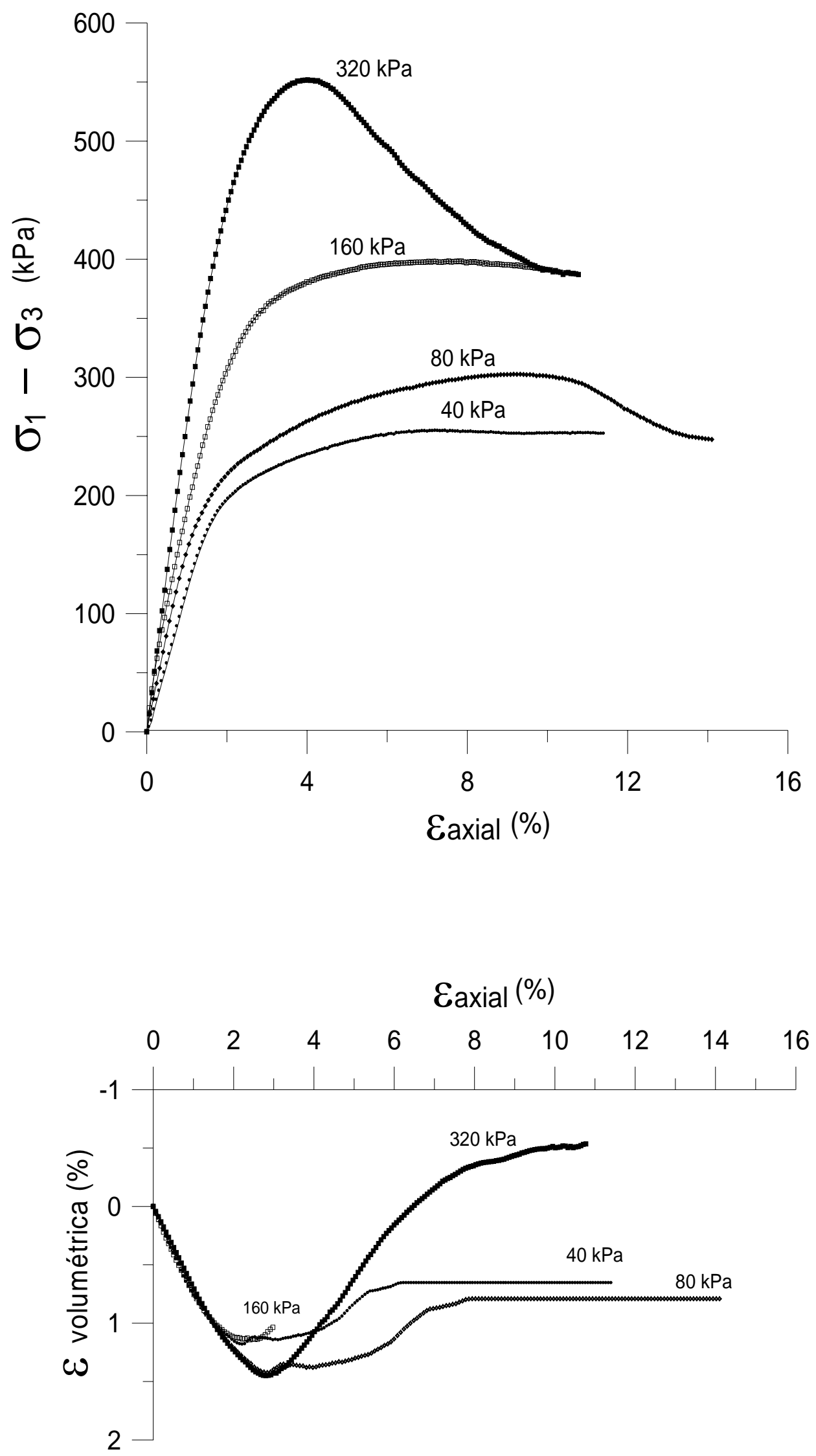

Figura 5.4 - Efeito da sucção na curva tensão versus deformação e deformação axial versus volumétrica, solo maduro, para tensão confinante igual a $50 \mathrm{kPa}$. 


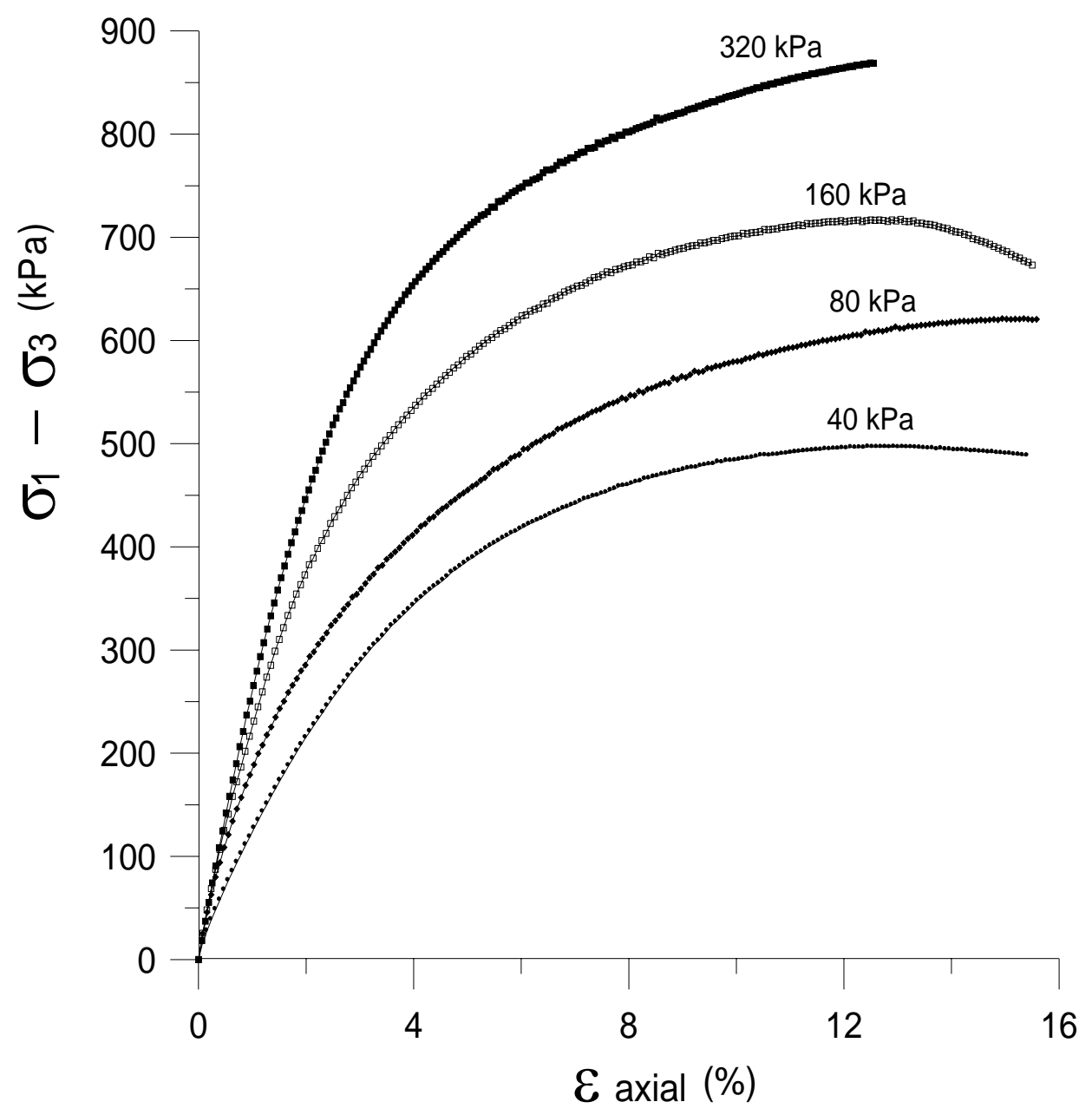

Eaxial (\%)

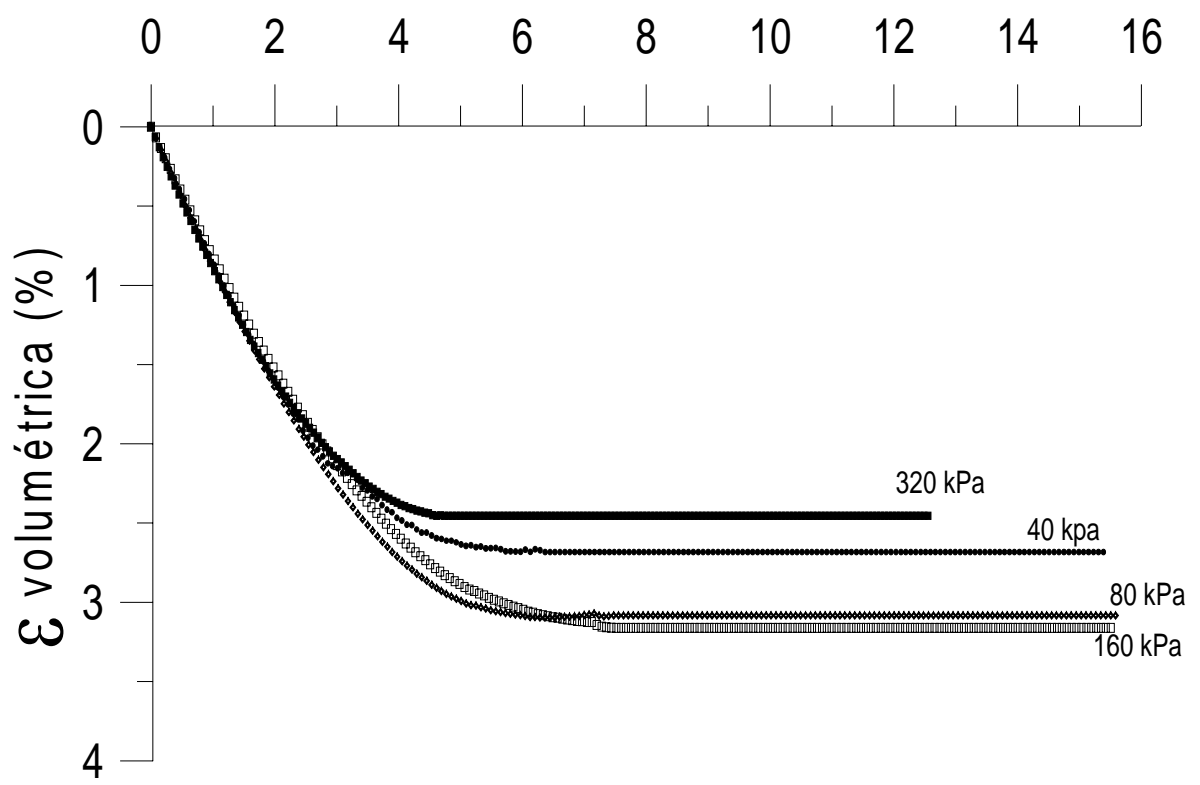

Figura 5.5 - Efeito da sucção na curva tensão versus deformação e deformação axial versus volumétrica, solo maduro, para tensão confinante igual a $200 \mathrm{kPa}$. 
A forma das curvas tensão desviadora versus deformação axial apresentadas para os dois solos mostra de maneira bem clara a influência da sucção no comportamento tensão-deformação. Percebe-se que para sucções mais baixas as amostras dos dois solos são menos rígidas do que para sucções mais altas e que o comportamento na ruptura para o solo em sucções mais baixas é mais plástico enquanto que para o solo em sucções mais altas é mais frágil.

Percebe-se destas figuras, que o comportamento mais frágil, observado nas curvas tensão versus deformação está associado à dilatância nas curvas deformação axial versus deformação volumétrica, enquanto o comportamento mais plástico está associado a ausência de dilatância nas curvas deformação axial versus deformação volumétrica.

\subsubsection{Análise da resistência e deformabilidade em condições saturadas}

\subsubsection{Análise da resistência}

A Tabela 5.2 apresenta os valores de coesão e ângulo de atrito encontrados para ambos os solos ensaiados em diferentes direções de cisalhamento. Pode ser visto, que o ângulo de atrito efetivo não muda significativamente, enquanto a coesão varia levemente com a direção de carregamento.

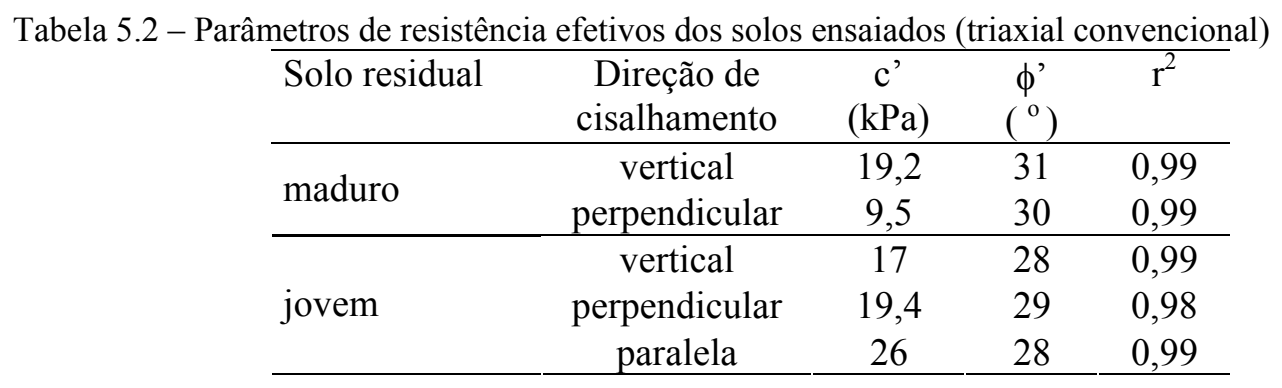

Como os parâmetros de resistência não variam muito com a direção de cisalhamento uma única envoltória de resistência foi ajustada para cada solo. As Figuras 5.6 e 5.7 apresentam, respectivamente, as envoltórias de ruptura obtidas para os solos maduro e jovem. Para o solo maduro a coesão efetiva foi igual a $15 \mathrm{kPa}$ e o ângulo de atrito efetivo igual a 31 graus. Para o solo jovem a coesão efetiva foi igual a $17 \mathrm{kPa}$ e o ângulo de atrito igual a 29 graus. Baseando-se nas lâminas realizadas dos dois solos e 
nos resultados mecânicos dos dois solos pode-se dizer que os rearranjos que ocorrem tanto no solo jovem como no maduro, desde o início do cisalhamento até a ruptura, produzem independentemente da direção de carregamento o mesmo efeito na resistência ao cisalhamento, isso considerando cada solo separadamente.

Com respeito ao intemperismo, o solo maduro apresenta, na direção vertical, coesão praticamente igual a do solo jovem e ângulo de atrito levemente superior, apesar de seu índice de vazios $(\mathrm{e}=1,07)$ ser muito maior que o do solo jovem $(\mathrm{e}=0.72)$. Uma possível explicação para isto vem da microestrutura destes solos, que apresenta agentes cimentantes entre partículas e também sofre rearranjos durante o cisalhamento, mostrada anteriormente através de fotos de lâminas delgadas obtidas deste solo, que faz com que a resistência final deste material seja igual ou superior à do solo jovem .

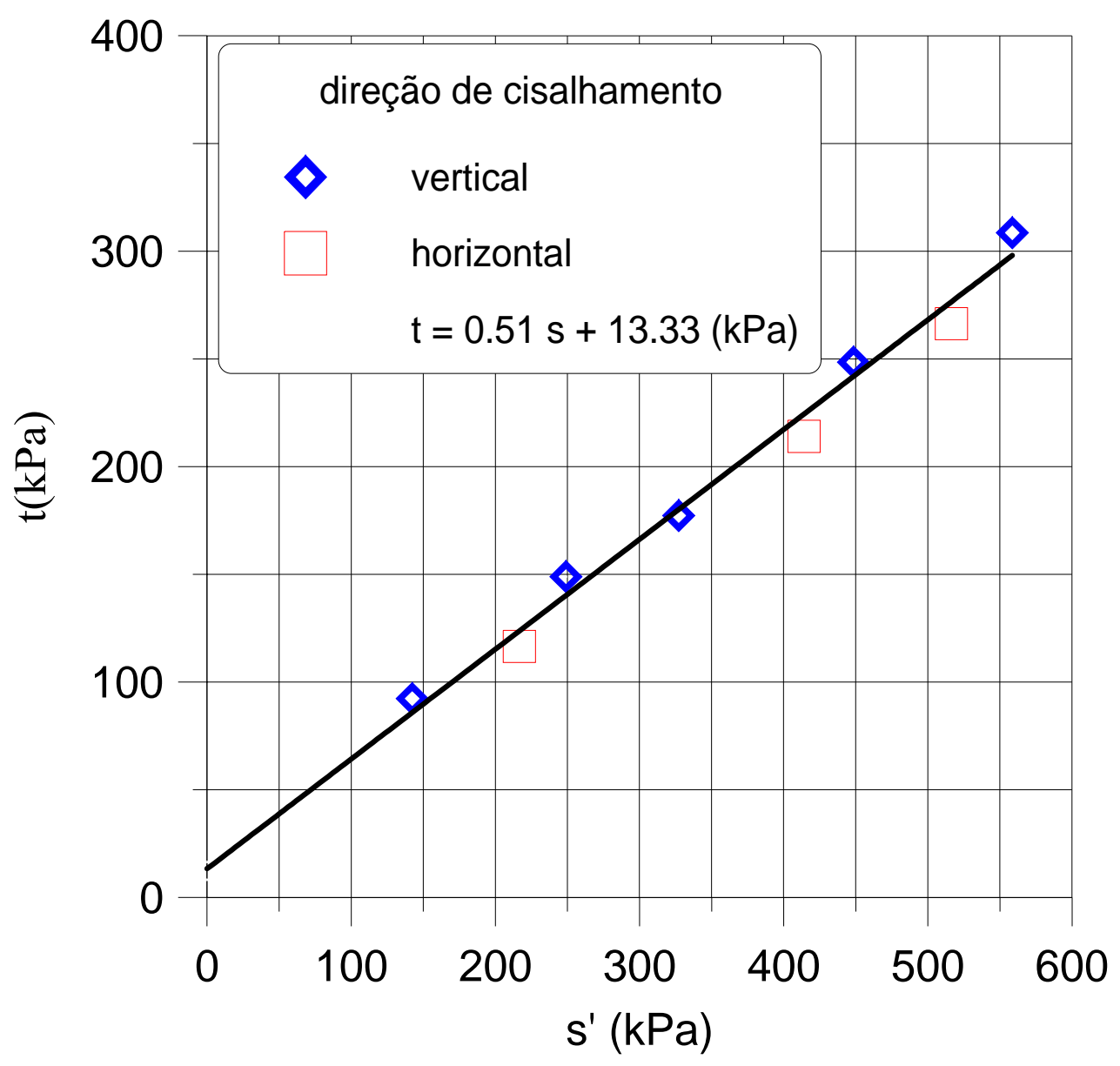

Figura 5.6 - Envoltória de ruptura do solo maduro considerando o efeito da direção de carregamento. Nesta figura: $\mathrm{t}=\left(\sigma_{1}-\sigma_{3}\right) / 2, \mathrm{~s}^{\prime}=\left(\sigma_{1}{ }^{\prime}+\sigma_{3}{ }^{\prime}\right) / 2$. 


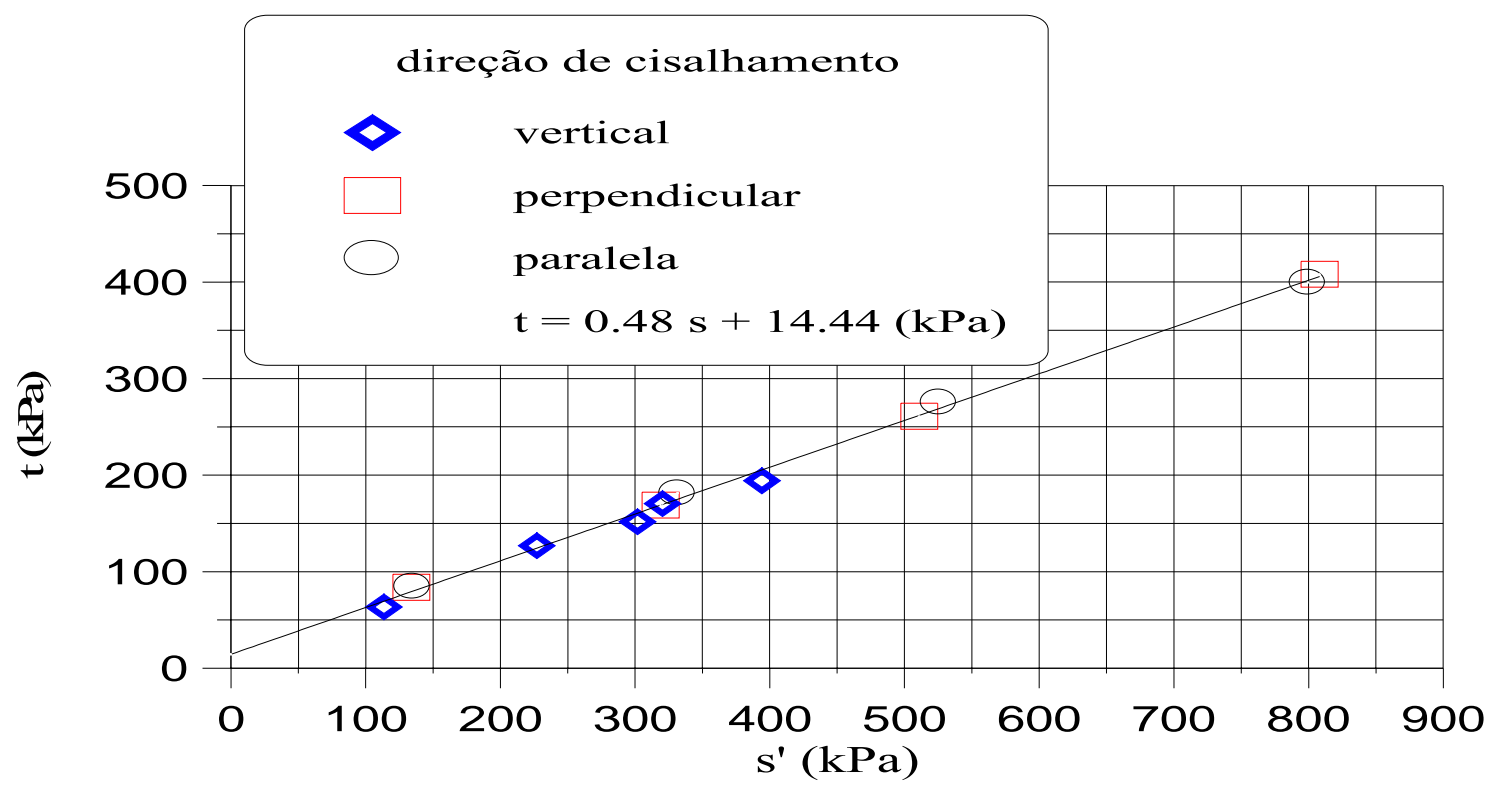

Figura 5.7 - Envoltória de ruptura do solo jovem, considerando o efeito da direção de carregamento. Nesta figura: $\mathrm{t}=\left(\sigma_{1}-\sigma_{3}\right) / 2, \mathrm{~s}^{\prime}=\left(\sigma_{1}{ }^{\prime}+\sigma_{3}{ }^{\prime}\right) / 2$.

Para o solo jovem, com intuito de verificar a anisotropia ou não da resistência em função do nível de deformação, foi feito o diagrama $\mathrm{t}(\mathrm{kPa})$ versus s' $(\mathrm{kPa})$ para diferentes níveis de deformção, em duas direções de carregamento (Figuras 5.8 e 5.9).

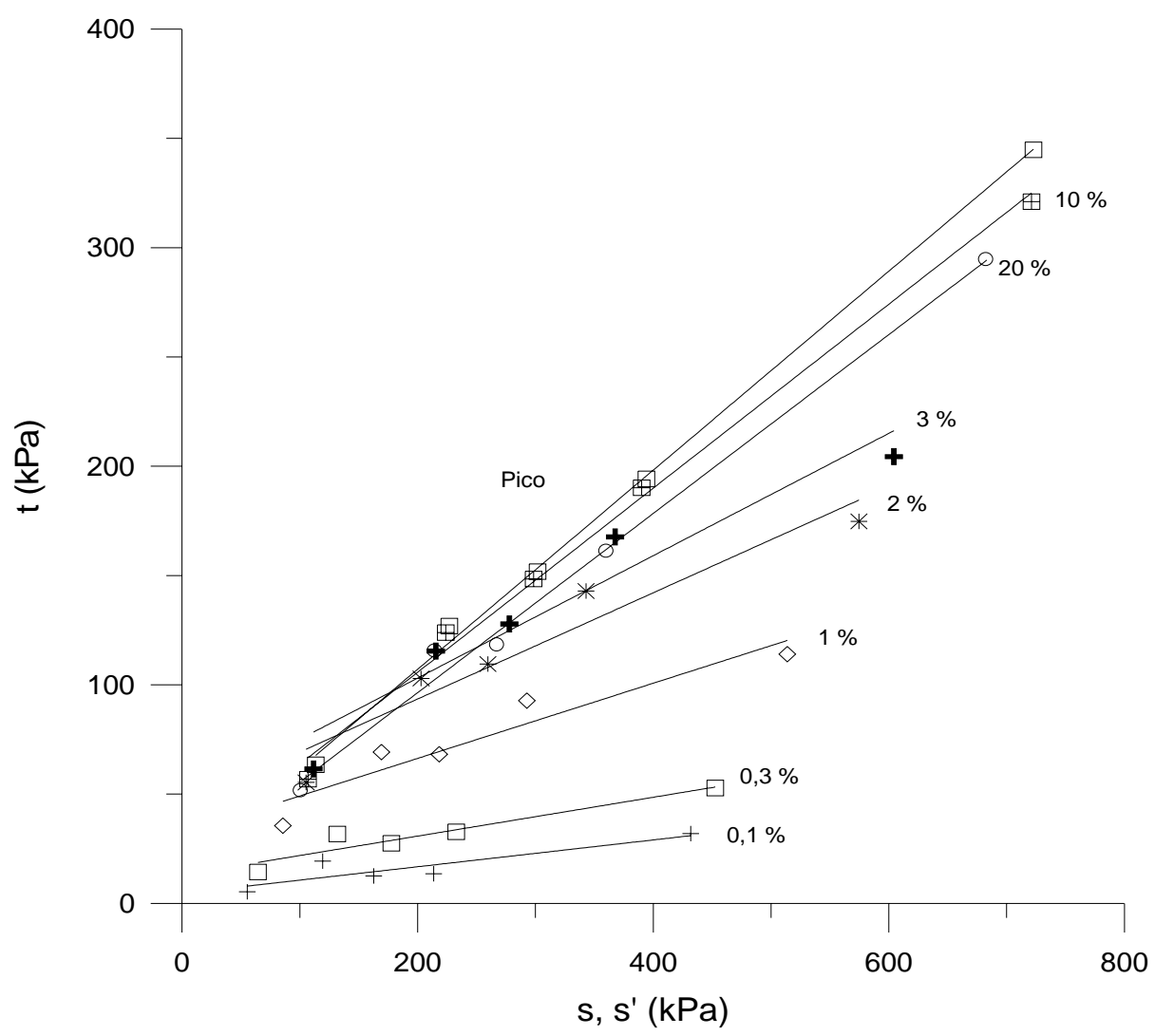

Figura 5.8 - Resistência mobilizada para diferentes níveis de deformação (direção vertical). 


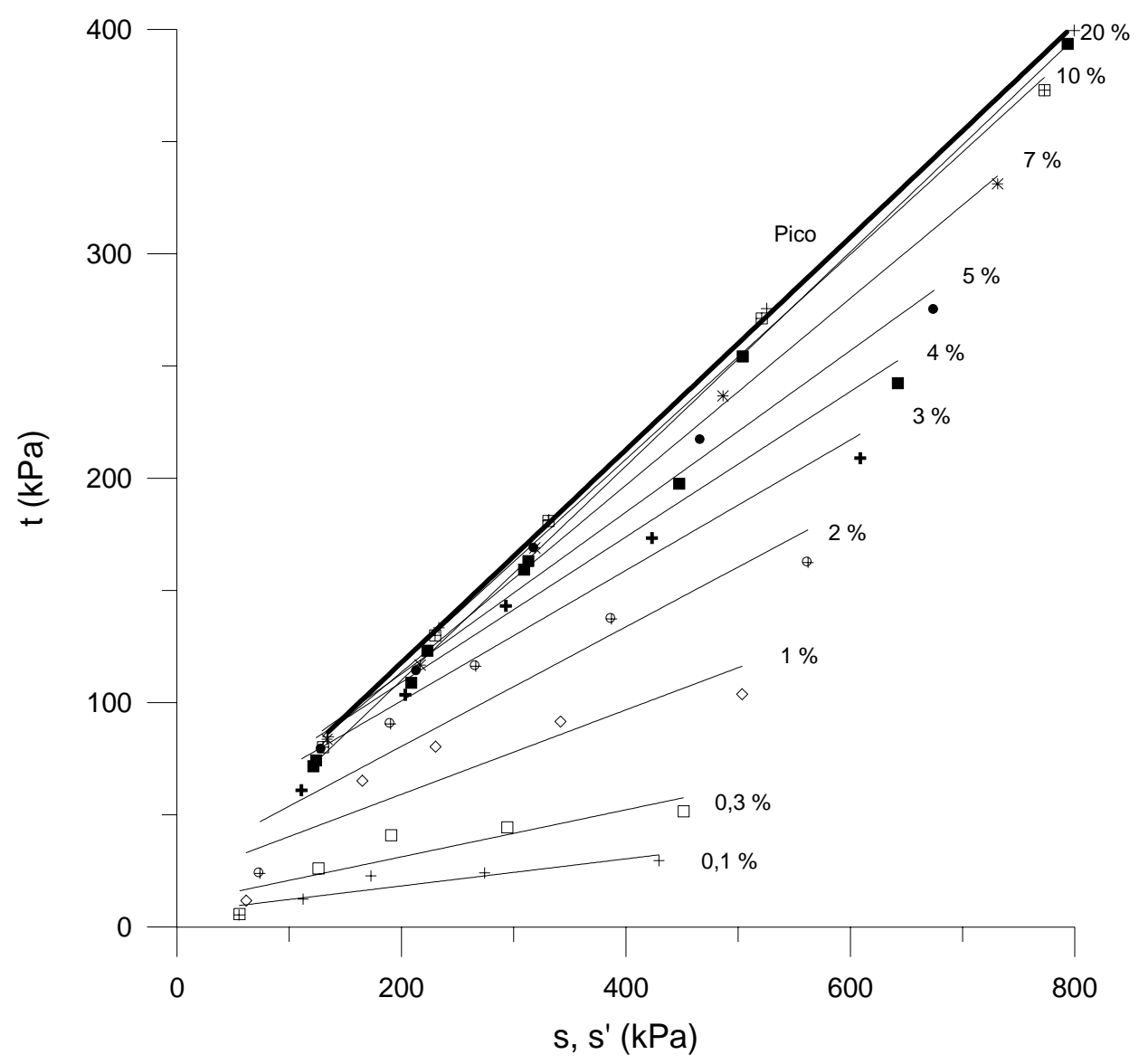

Figura 5.9 - Resistência mobilizada para diferentes níveis de deformação (direção paralela).

As Tabela 5.3 e 5.4 mostram os valores de coesão e ângulo de atrito, encontrados para diferentes níveis de deformação.

Tabela 5.3 - Valores de coesão e ângulo de atrito para diferentes níveis de deformação axial (direção vertical)

\begin{tabular}{cccc}
\hline$\varepsilon_{\text {axial }}(\%)$ & Coesão $(\mathrm{kPa})$ & Ângulo de atrito $\left(^{\circ}\right)$ & $\mathrm{R}^{2}$ \\
\hline 0,1 & 4,5 & 3,5 & 0,8 \\
0,3 & 13,1 & 5,1 & 0,91 \\
1 & 32,3 & 9,9 & 0,9 \\
2 & 46,3 & 14,1 & 0,92 \\
3 & 49,1 & 16,3 & 0,96 \\
4 & 45,5 & 18,7 & 0,97 \\
5 & 39,7 & 20,8 & 0,98 \\
10 & 23,7 & 24,8 & 0,99 \\
20 & 20,6 & 23 & 0,99 \\
\hline
\end{tabular}


Tabela 5.4 - Valores de coesão e ângulo de atrito para diferentes níveis de deformação axial (direção paralela)

\begin{tabular}{cccc}
\hline$\varepsilon_{\text {axial }}(\%)$ & Coesão $(\mathrm{kPa})$ & Angulo de atrito $\left(^{\circ}\right)$ & $\mathrm{R}^{2}$ \\
\hline 0,1 & 6,2 & 3,4 & 0,83 \\
0,3 & 10,3 & 6 & 0,8 \\
1 & 21,9 & 11 & 0,8 \\
2 & 28,3 & 15,7 & 0,9 \\
3 & 44,3 & 16,9 & 0,96 \\
4 & 46,5 & 18,7 & 0,97 \\
5 & 43,9 & 21,1 & 0,98 \\
7 & 33,3 & 24,8 & 0,99 \\
10 & 28,3 & 27,4 & 0,99 \\
12 & 21 & 28 & 0,99 \\
15 & 20,6 & 28,7 & 0,99 \\
20 & 16,4 & 28,7 & 0,99 \\
\hline
\end{tabular}

A Figura 5.10 mostra a variação da coesão e ângulo de atrito com a deformação axial para as duas direções analizadas.

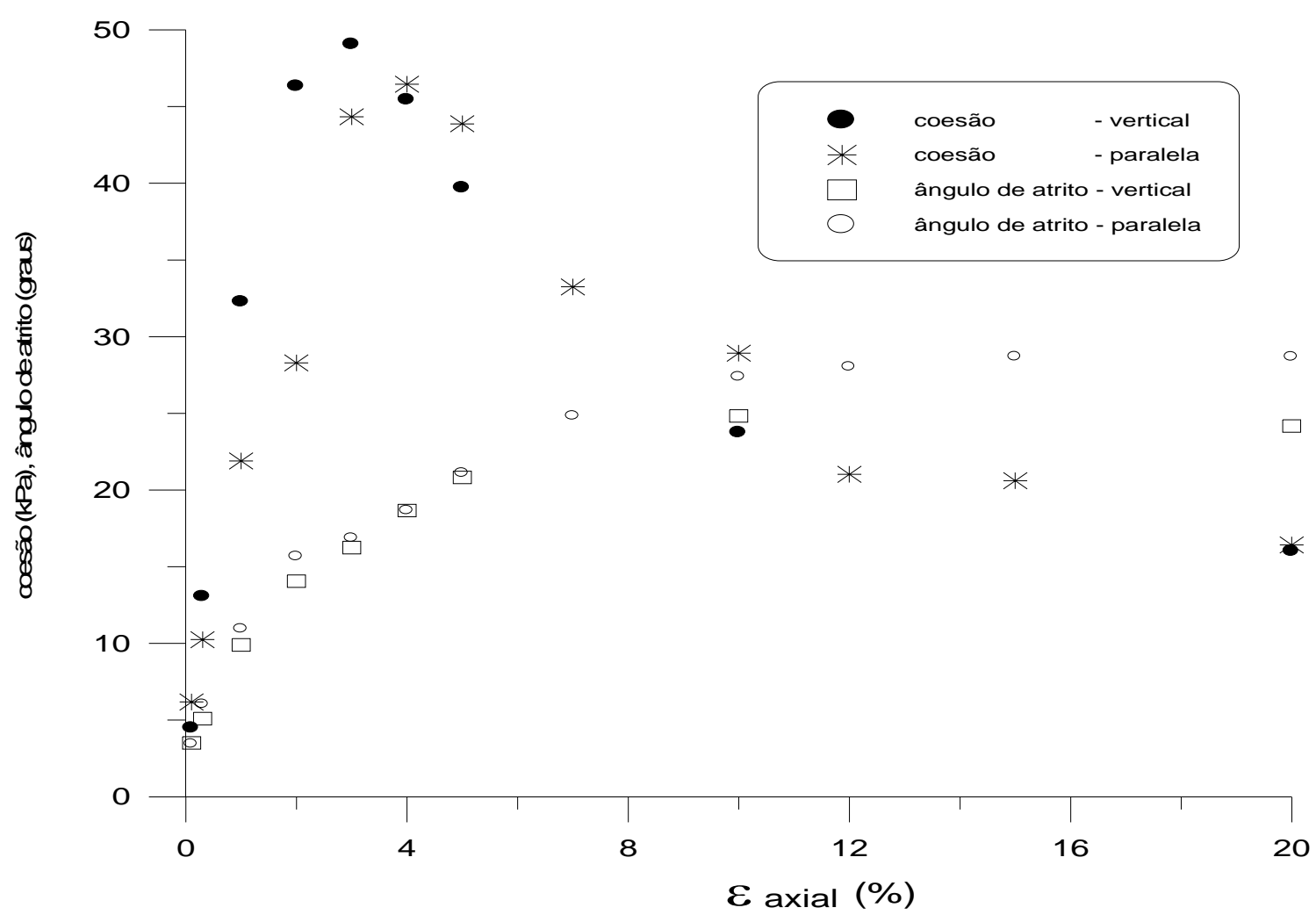

Figura 5.10 - Variação do ângulo de atrito e da coesão em função do nível de deformação, para duas direções de carregamento. 
Percebe-se desta figura que a coesão e o ângulo de atrito praticamente não variaram com a direção de cisalhamento, para diferentes níveis de deformação axial, indicando assim que o solo, quanto à resistência é isotrópico independente do nível de deformação. A coesão aumentou até o nível de deformação correspondente a aproximadamente $4 \%$ e depois decresceu até mais ou menos $12 \%$, onde começa tender à estabilização. $\mathrm{O}$ ângulo de atrito aumentou aproximadamente até $9 \%$ de deformação axial, onde a partir da qual começa tender à estabilização.

\subsubsection{Análise da deformabilidade}

A Tabela 5.5 apresenta valores de módulos de elasticidade $\left(\mathrm{E}_{50}\right)$ e coeficiente de Poisson (v) obtidos para ambos os solos em um nível de tensão correspondente a $50 \%$ da tensão de ruptura.

Dos resultados apresentados na Tabela 5.5, pode ser observado que os ensaios com diferentes direções de cisalhamentos realizados no solo jovem apresentaram valores de $\mathrm{E}$ e $v$ praticamente iguais, indicando assim que este solo tem um comportamento isotrópico. Por outro lado, para o solo maduro, os ensaios com diferentes direções de cisalhamento apresentaram valores de E e $v$ bastante variáveis, indicando assim um comportamento anisotrópico. 
Tabela 5.5 - Efeito da direção de carregamento na deformabilidade

\begin{tabular}{cccc}
\hline Solo residual & $\begin{array}{c}\text { Pressão } \\
\text { confinante } \\
(\mathrm{kPa})\end{array}$ & $\mathrm{E}_{50}$ & $v_{50}$ \\
& 50 & 10,65 & 0,15 \\
& 100 & 14,16 & 0,08 \\
Maduro & 150 & 7,66 & 0,19 \\
& 200 & 11,70 & 0,12 \\
(direção vertical) & 250 & 24,72 & 0,15 \\
\hline Maduro & 100 & 9,80 & 0,20 \\
& 200 & 6,66 & 0,21 \\
( direção horizontal) & 250 & 5,92 & 0,24 \\
\hline & 50 & 8,10 & 0,20 \\
Jovem & 150 & 13,60 & 0,18 \\
(direção vertical ) & 200 & 17,60 & 0,14 \\
& 250 & $\ldots \ldots .$. & $\ldots \ldots .$. \\
& 400 & 17,60 & 0,12 \\
\hline & 50 & 7,20 & 0,25 \\
Jovem & 150 & 14,80 & 0,20 \\
(direção paralela em relação & 200 & $\ldots \ldots$. & $\ldots \ldots$. \\
ao bandamento) & 250 & 16,10 & 0,13 \\
& 400 & 13,80 & 0,17 \\
\hline & 50 & 7,20 & 0,25 \\
Jovem & 150 & 18,20 & 0,19 \\
(direção perpendicular em & 200 & $\ldots \ldots$. & $\ldots \ldots$. \\
relação ao bandamento) & 250 & 18,80 & 0,14 \\
& 400 & 16,40 & 0,17 \\
\hline & & &
\end{tabular}

O módulo de elasticidade $\left(\mathrm{E}_{50}\right)$ do solo residual jovem aumentou com a tensão confinante até ela alcançar o valor de $250 \mathrm{kPa}$, que é próximo da tensão de cedência determinada no ensaio de compressão hidrostática. Depois desta tensão, $\mathrm{E}_{50}$ decresce levemente quando comparado com o valor calculado para tensão confinante de $250 \mathrm{kPa}$. A influência da direção de cisalhamento não foi significativa uma vez que valores medidos em cada direção desviaram muito pouco do valor médio, indicando um comportamento praticamente isotrópico que parece distante do comportamento de deformação que se esperaria de um solo jovem. Porém os resultados mecânicos obtidos, indicando platicamente uma possível isotropia (apresenta uma leve anisotopia), podem ser explicados pela microestrutura destes solos, que é comandada pelos pseudomorfos de biotita. Estes, retratam o alto grau de intemperismo destes solos, são altamente compressíveis de uma maneira praticamente similar, independente da direção de carregamento e estão dispersos no solo de uma forma caótica sugerindo assim um material sem estruturação significante ou seja um material praticamente homogêneo no nível de microestrutura. 
Para o solo maduro, não foi possível definir uma tendência para a variação do módulo $\mathrm{E}_{50}$ com a pressão de confinamento na direção vertical. Na direção horizontal, no entanto, o módulo de elasticidade $\mathrm{E}_{50}$ decresce com o aumento do valor da tensão de confinamento. É interessante notar que embora o solo residual jovem apresente os bandeamentos herdados da rocha mãe seu comportamento quanto à deformação foi bem mais isotrópico que o do solo maduro.

Uma possível explicação para estas características pode ser devido à heterogeneidade do solo maduro que é muito maior que o sugerido por observações visuais. Esta heterogeneidade provavelmente é comandada pela microestrutura destes solos, conforme visto anteriormente, resultante de processos de intemperismo que agem no solo. Estes processos deixam o solo mais poroso, índice de vazios igual a 1,07, e também depositam óxidos de ferro e alumínio que geram alguma ação cimentante. Estes dois aspectos provavelmente agem de maneiras diferentes: a maior porosidade comanda a maior deformabilidade do solo maduro, enquanto os agentes cimentantes e a facilidade de se rearranjar, melhoram a resistência ao cisalhamento deste solo, fazendo com que ela seja, praticamente igual ou maior que a do solo jovem.

A microestrutura do solo maduro muito propícia a rearranjos microestruturais, conforme visto nas fotos comentadas anteriormente, e que se mostra heterogênea e anisotrópica como um todo explica de maneira razoável o comportamento anisotrópico obtido pelo solo maduro.

As Figuras 5.11 a 5.16 mostram a variação do módulo de elasticidade com a deformação axial para as três direções ensaiadas e para as diferentes tensões confinantes, no solo jovem. 


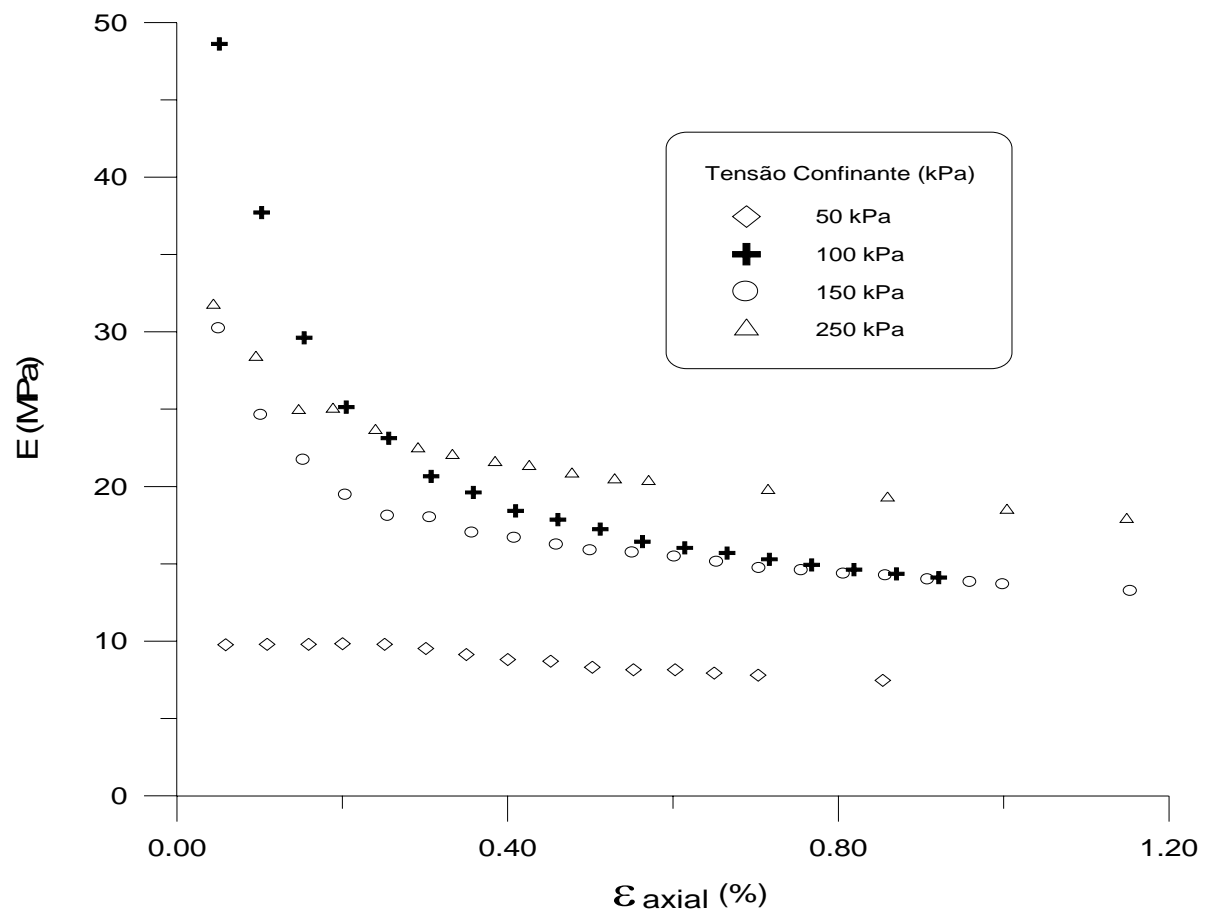

Figura 5.11 - Variação do módulo de elasticidade com a deformação axial, para diferentes tensões confinantes (jovem - direção vertical)

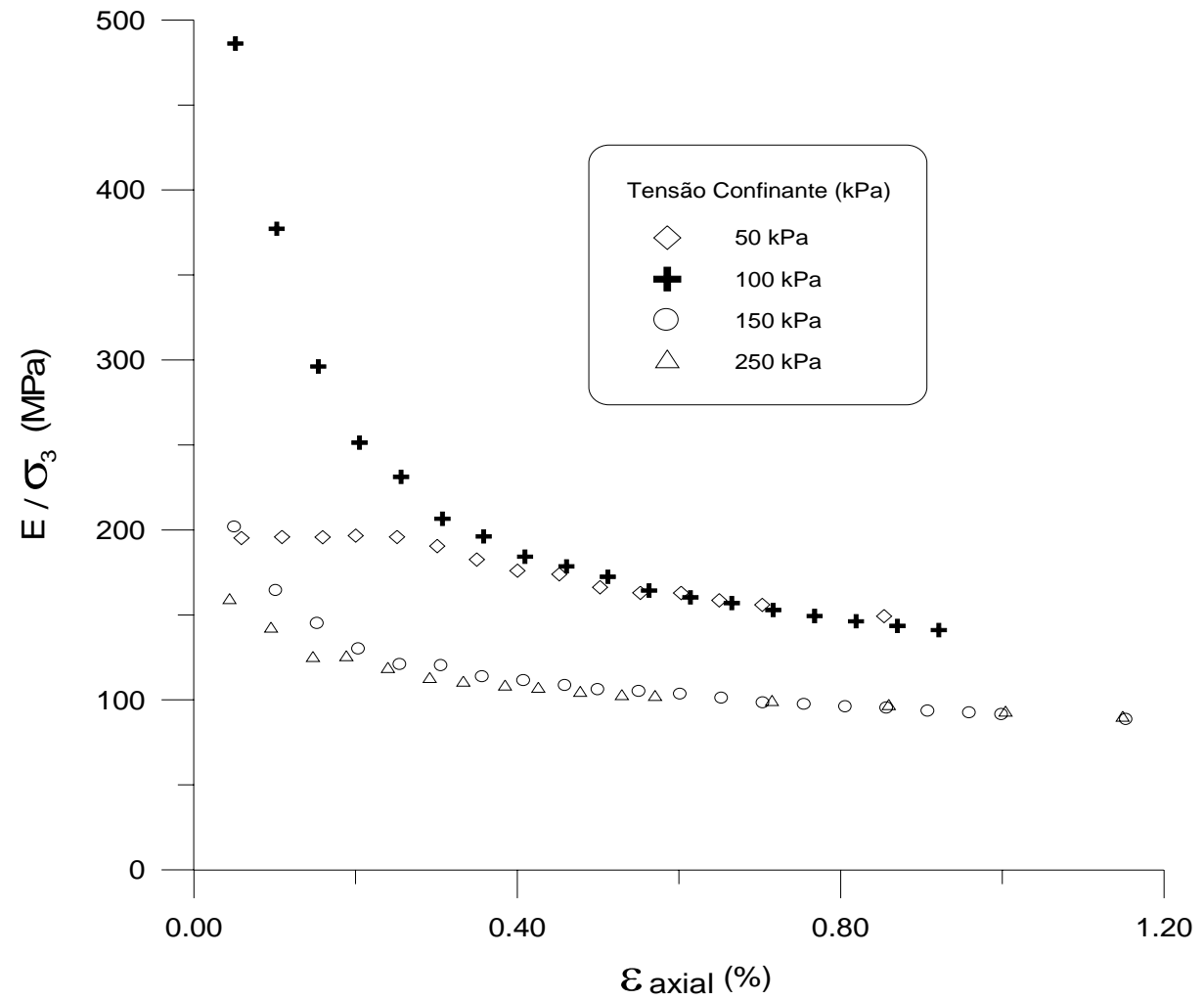

Figura 5.12 - Variação de $\mathrm{E} / \sigma_{3}$ com a deformação axial, para diferentes tensões confinantes (jovem direção vertical). 


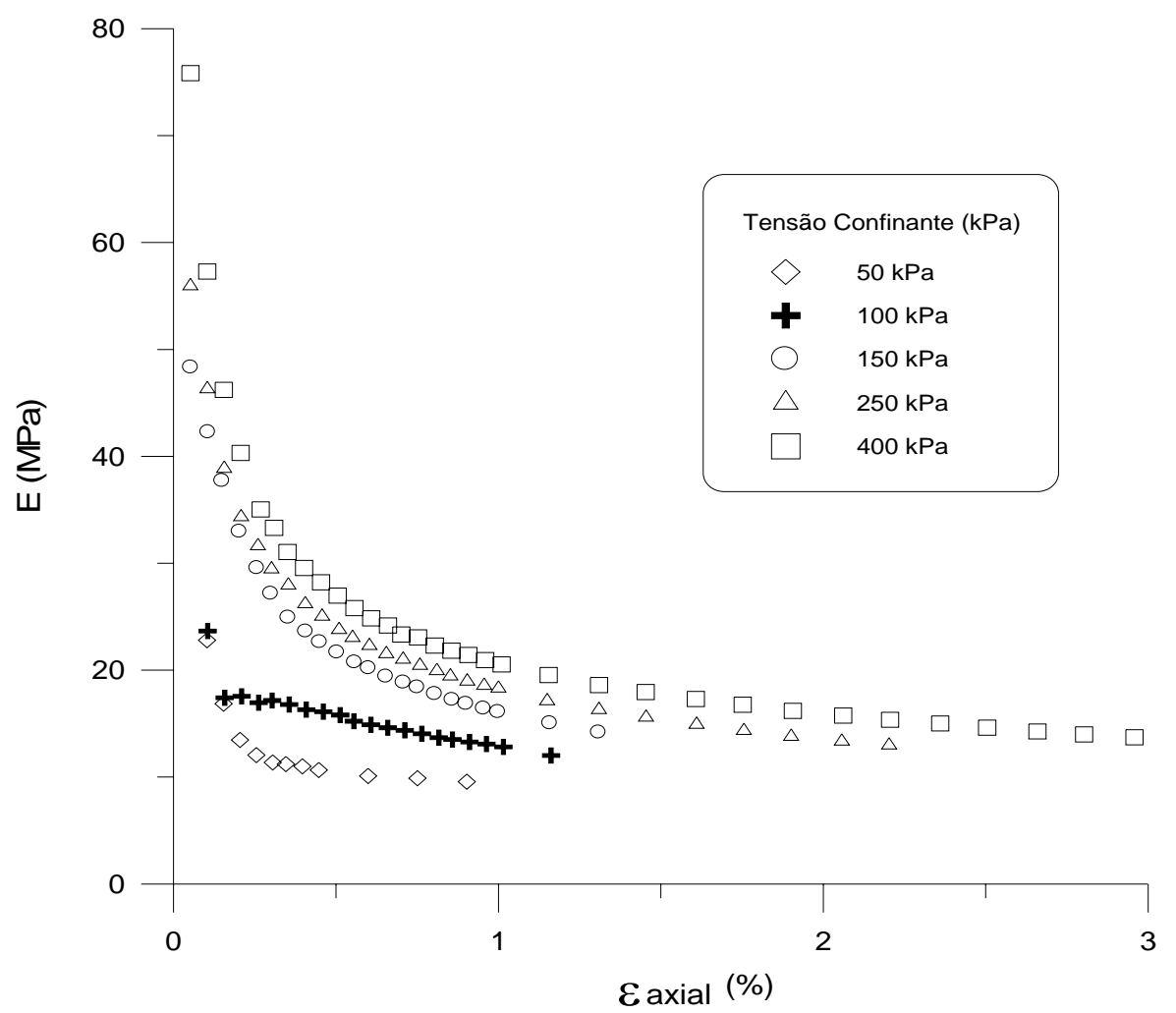

Figura 5.13 - Variação do módulo de elasticidade com a deformação axial, para diferentes tensões confinantes (jovem - direção paralela).

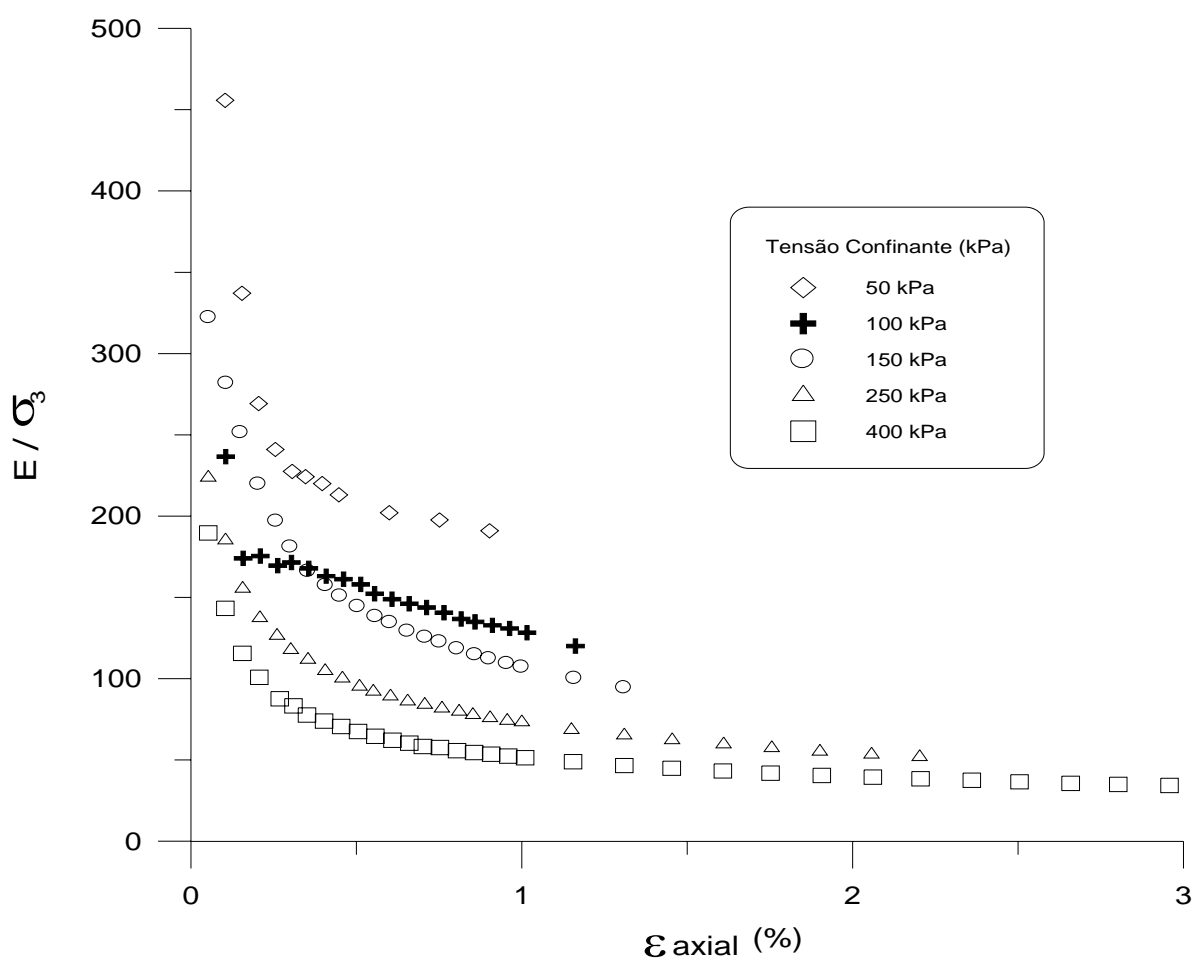

Figura 5.14 - Variação de $\mathrm{E} / \sigma_{3}$ com a deformação axial, para diferentes tensões confinantes (jovem direção paralela). 


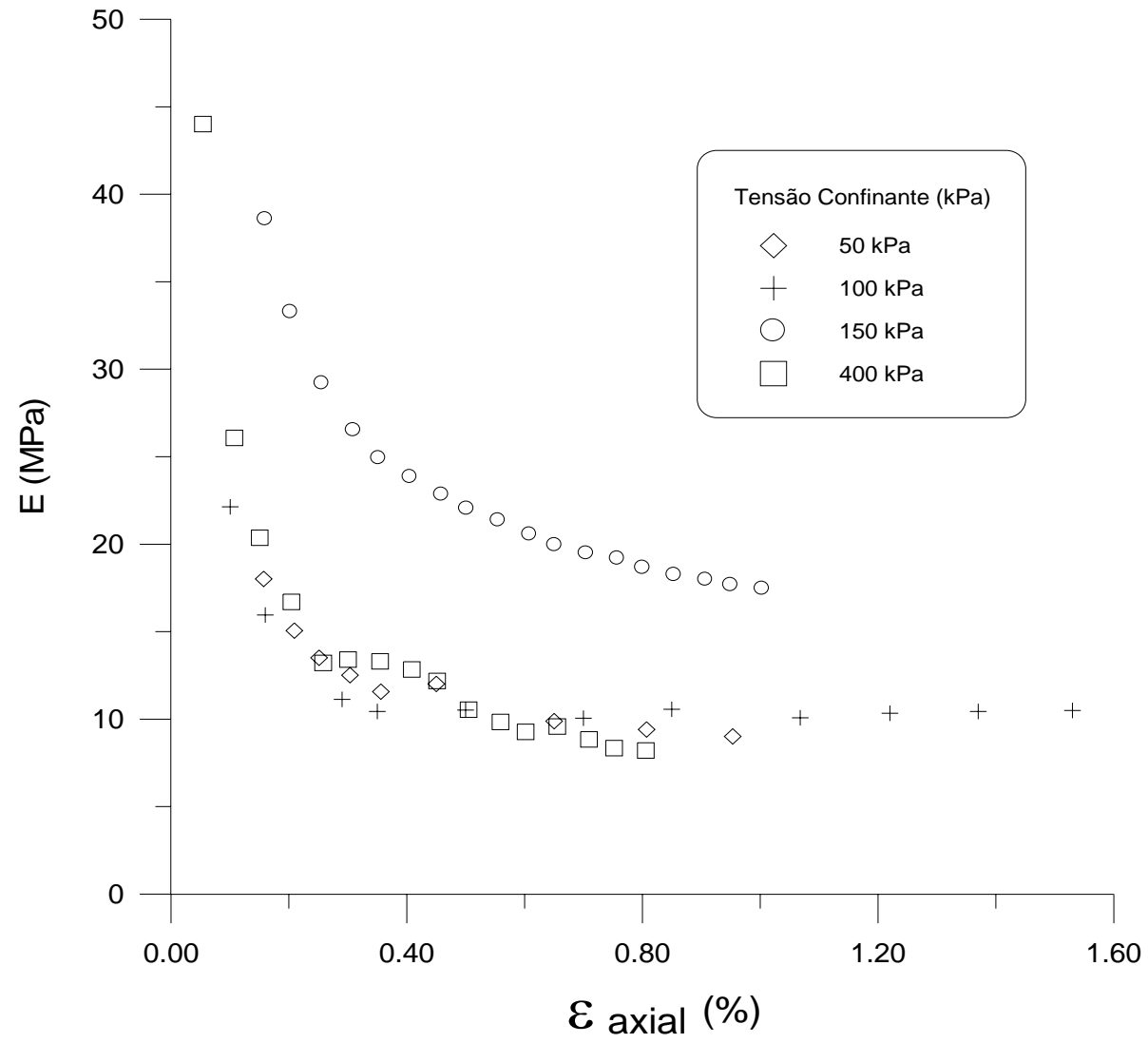

Figura 5.15 - Variação do módulo de elasticidade com a deformação axial, para diferentes tensões confinantes (jovem - direção perpendicular).

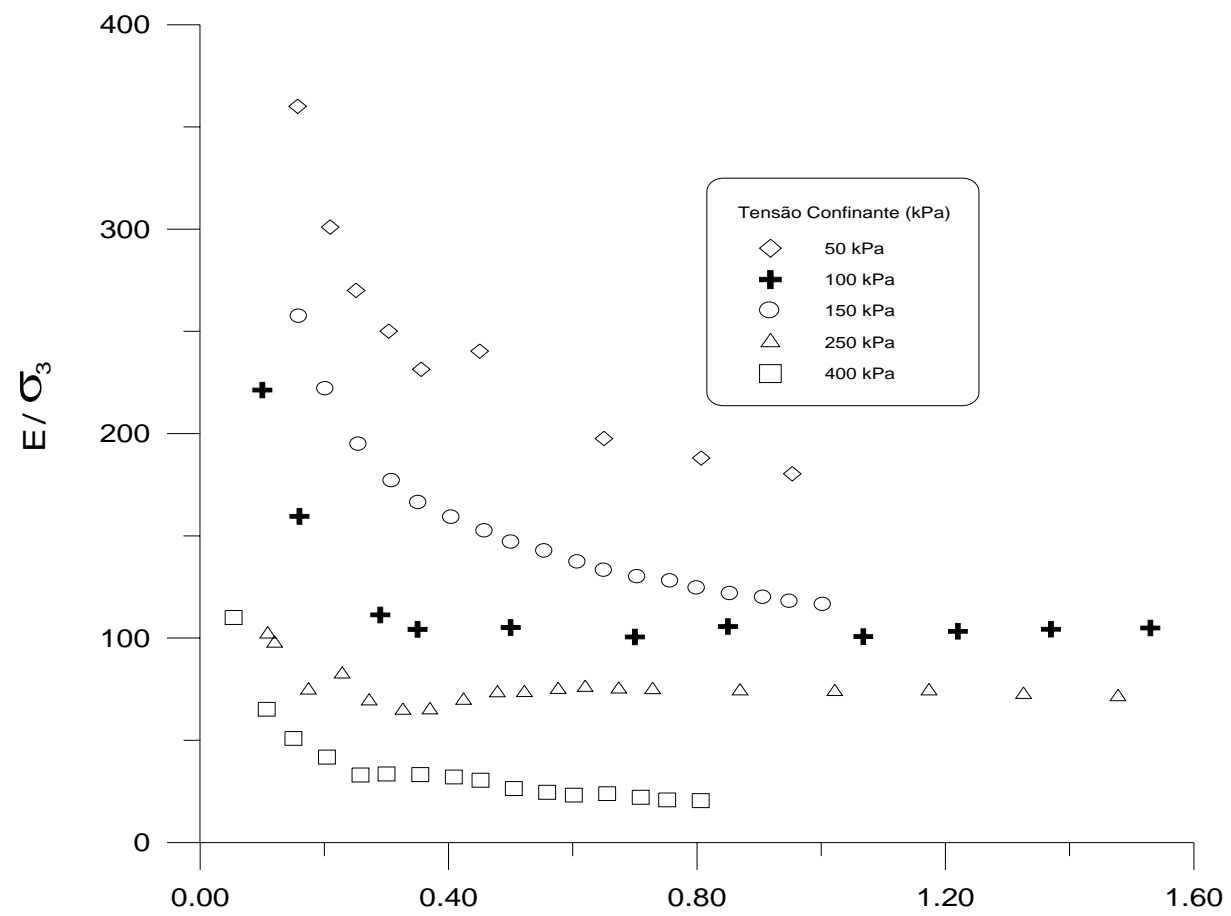

Figura 5.16 - Variação de $\mathrm{E} / \sigma_{3}$ com a deformação axial, para diferentes tensões confinantes (jovem direção perpendicular). 
Destas figuras percebe-se que o módulo de elasticidade decresce acentuadamente para baixos valores de deformação axial e tende a ficar constante para valores de deformação axial a partir de $1 \%$. Para as curvas E/ $\sigma_{3}$ (módulo de elasticidade dividido pela tensão confinante) versus a deformação axial, percebeu-se que elas não se juntaram, o que mostra que a tensão confinante, para este solo, exerce efeito no módulo de elasticidade ou seja o módulo de elasticidade depende da tensão confinante aplicada. Percebeu-se, também destas figuras, que as curvas referentes as tensões confinantes mais baixas, por exemplo $50 \mathrm{kPa}$, apresentaram valores maiores de $\mathrm{E} / \sigma_{3}$, enquanto que as curvas referentes as tensões confinantes mais altas, por exemplo $400 \mathrm{kPa}$, apresentaram valores menores de $\mathrm{E} / \sigma_{3}$; Isto pode ser explicado pelo fato de o solo com $50 \mathrm{kPa}$ de confinamento, menor que $265 \mathrm{kPa}$ (tensão de pré-adensamento do solo), estar pré-adensado e o solo com $400 \mathrm{kPa}$ estar normalmente adensado.

A Tabela 5.6 mostra o módulo de elasticidade (Mpa) para as três direções ensaiadas em diferentes valores de deformação axial e de tensão de confinamento, retirados das figuras $(5.11,5.13$ e 5.15), mostradas anteriormente.

Tabela 5.6 - Módulos de elasticidade para diferentes direções de carregamento e tensões confinantes, em diferentes níveis de deformação axial.

\begin{tabular}{|c|c|c|c|c|c|c|c|c|c|}
\hline \multirow{2}{*}{$\begin{array}{c}\varepsilon_{\text {axial }} \\
(\%)\end{array}$} & \multicolumn{3}{|c|}{$\begin{array}{c}\text { Direção Vertical } \\
\left(\sigma_{3}-\mathrm{kPa}\right)\end{array}$} & \multicolumn{3}{c|}{$\begin{array}{c}\text { Direção Paralela } \\
\left(\sigma_{3}-\mathrm{kPa}\right)\end{array}$} & \multicolumn{3}{c|}{$\begin{array}{c}\text { Direção Perpendicular } \\
\left(\sigma_{3}-\mathrm{kPa}\right)\end{array}$} \\
\cline { 2 - 10 } & 50 & 100 & 150 & 50 & 100 & 150 & 50 & 100 & 150 \\
\hline 0,2 & 10 & 24,5 & 19,5 & 14 & 18 & 36 & 15,8 & 14,5 & 33 \\
\hline 0,4 & 9 & 18,5 & 16,5 & 11 & 16 & 24 & 10,8 & 10 & 23,8 \\
\hline 0,6 & 8 & 16 & 15 & 10 & 15 & 20 & 10 & 10 & 21 \\
\hline 0,8 & 7 & 14 & 14 & 9,7 & 14 & 18 & 9,5 & 10 & 18,5 \\
\hline 1 & 7 & 13 & 13 & 9,7 & 13 & 16 & 9 & 10 & 17,5 \\
\hline
\end{tabular}

Desta tabela verifica-se que o solo quanto a deformabilidade apresenta uma leve anisotropia, podendo em alguns níveis de deformação e determinada tensão confinante ser considerado isotrópico. 


\subsubsection{Análise da resistência em condições não saturadas com imposição e controle de sucção.}

As Figuras 5.17 e 5.18 mostram, respectivamente, as envoltórias de resistências, no diagrama $\mathrm{t}$ versus $\mathrm{s}-\mathrm{u}_{\mathrm{a}}\left(\mathrm{t}=\left(\sigma_{1}-\sigma_{3}\right) / 2\right.$ e $\left.\mathrm{s}-\mathrm{u}_{\mathrm{a}}=\left(\sigma_{1}+\sigma_{3}\right) / 2\right)$, para os solos jovem e maduro.

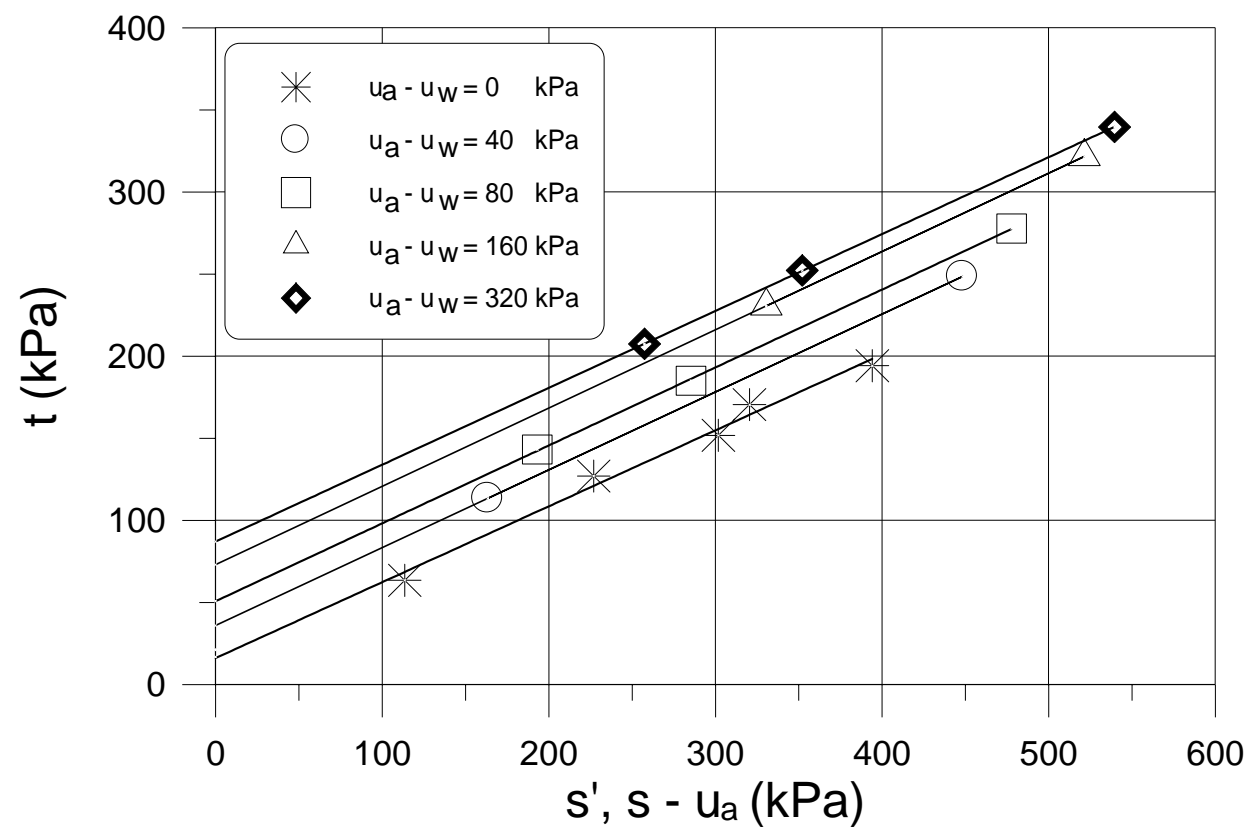

Figura 5.17 - Envoltórias de resistência obtidas para as sucções ensaiadas (solo jovem).

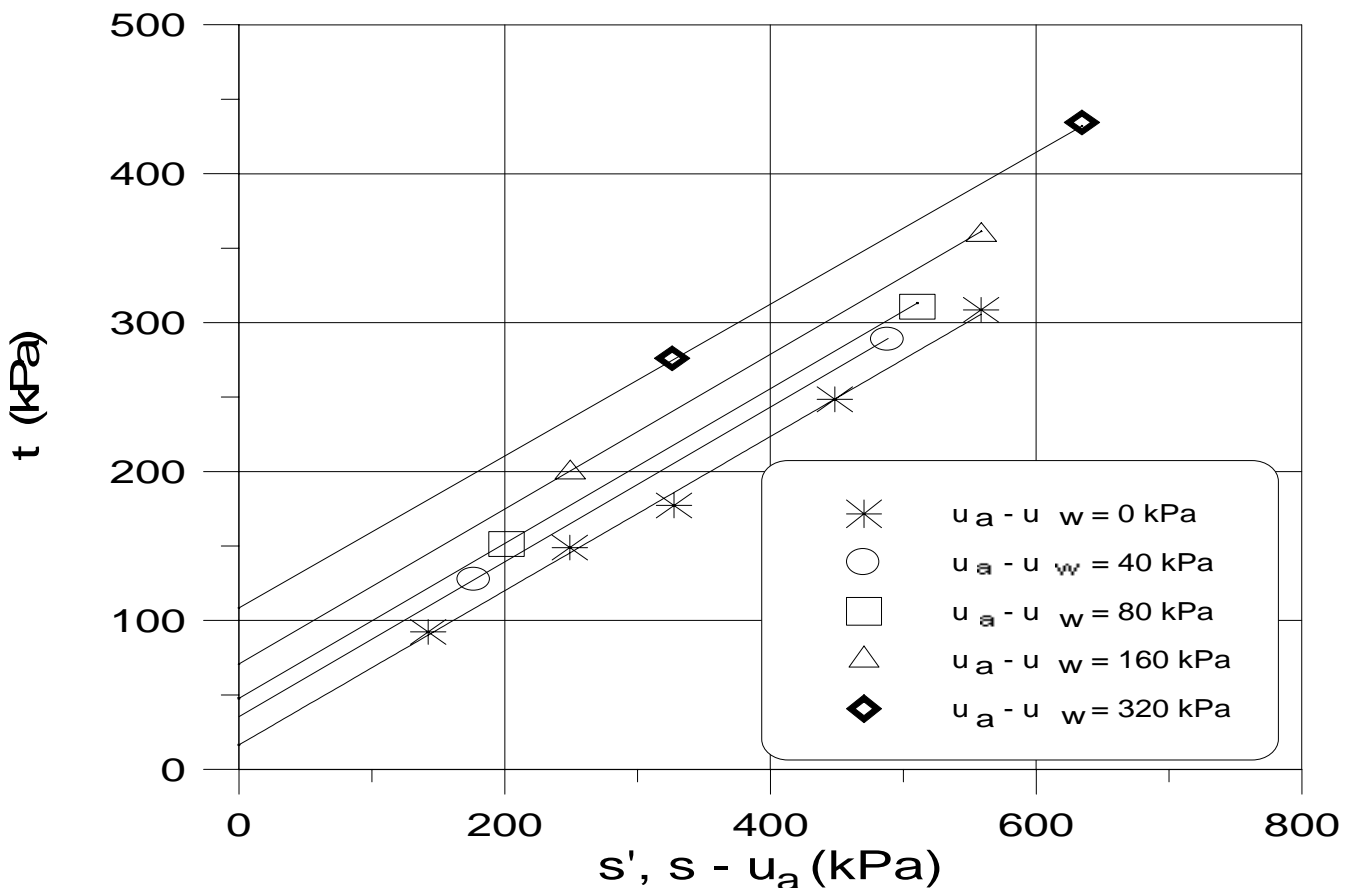

Figura 5.18 - Envoltórias de resistência obtidas para as sucções ensaiadas (solo maduro). 
A Tabela 5.7 apresenta os valores dos parâmetros de resistência, obtidos para os solos residuais, maduro e jovem nas sucções adotadas para a realização dos ensaios.

Tabela 5.7 - Valores de c e $\phi$ para as diferentes sucções adotadas nos ensaios.

\begin{tabular}{cccc}
\hline Solo residual & $\mathrm{u}_{\mathrm{a}}-\mathrm{u}_{\mathrm{w}}(\mathrm{kPa})$ & $\mathrm{c}(\mathrm{kPa})$ & $\phi$ (graus) \\
\hline \multirow{4}{*}{ maduro } & 0 & 19,2 & 31 \\
& 40 & 41,2 & 31 \\
& 80 & 55,4 & 31 \\
& 160 & 82,4 & 31 \\
jovem & 320 & 125,9 & 31 \\
& 0 & 17,4 & 28 \\
& 0 & 24 & 28 \\
& 40 & 40,8 & 28,3 \\
& 80 & 57,6 & 28,3 \\
& 160 & 83,1 & 28,4 \\
\hline
\end{tabular}

Percebe-se que o ângulo de atrito $(\phi)$ praticamente, não varia com a sucção para os dois solos. A variação da coesão em função da sucção é mostrada, nas Figuras 5.19 e 5.20, repectivamente, para o solo jovem e maduro, através do ajuste de uma função hiperbólica aos dados experimentais. A função hiperbólica foi ajustada aos pontos experimentais pela equação (5.1), utilizando-se o método dos mínimos quadrados, para obtenção dos parâmetros a e b.

$\mathrm{c}=\mathrm{c}^{\prime}+\left[\left(\mathrm{u}_{\mathrm{a}}-\mathrm{u}_{\mathrm{w}}\right) / \mathrm{a}+\mathrm{b} \cdot\left(\mathrm{u}_{\mathrm{a}}-\mathrm{u}_{\mathrm{w}}\right)\right]$

Nesta equação, c é a coesão do solo para um dado valor de sucção, c' é a coesão efetiva do solo, obtida para $\mathrm{u}_{\mathrm{a}}-\mathrm{u}_{\mathrm{w}}=0$, e a e b são parâmetros do solo.

A Tabela 5.8 apresenta os valores das constantes utilizadas no ajuste da equação 5.1 aos dados experimentais.

Tabela 5.8 - Valores adotados no ajuste da função hiperbólica aos dados experimentais

\begin{tabular}{ccccc}
\hline solo & c' & a & b & $r^{2}$ \\
\hline Jovem & 24 & 1,86 & 0,0072 & 0,94 \\
maduro & $19, .2$ & 1,80 & 0,0039 & 0,95 \\
\hline
\end{tabular}




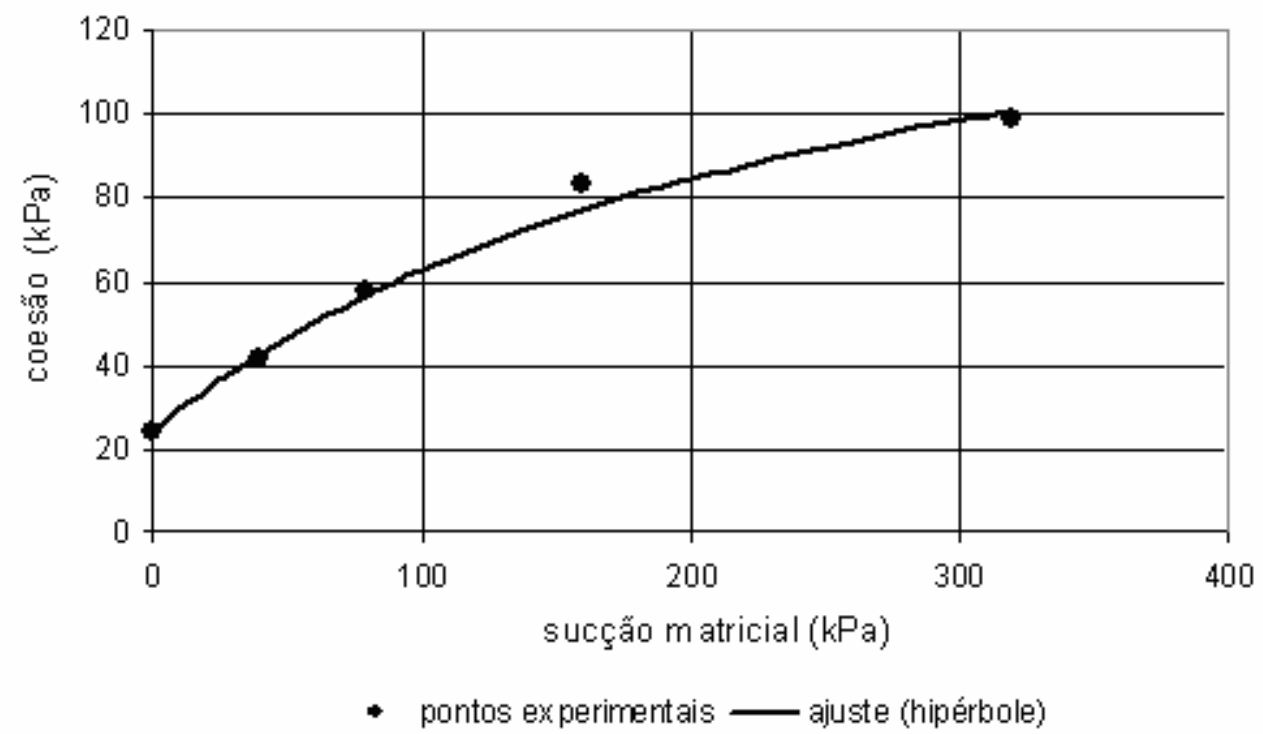

Figura 5.19 - Variação da coesão em função da sucção matricial (solo jovem)

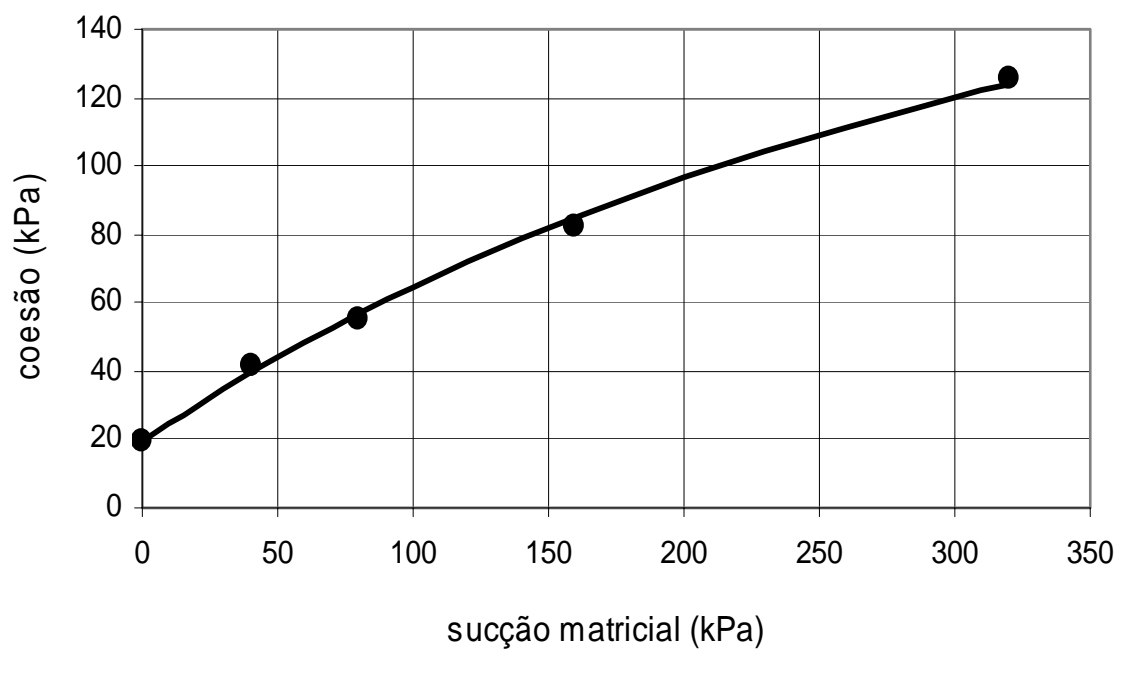

- pontos experimentais —ajuste (hipérbole)

Figura 5.20 - Variação da coesão em função da sucção matricial (solo maduro)

Estes resultados mostram, para os dois solos, que o intercepto de coesão relaciona-se com a sucção matricial segundo um modelo não linear (possivelmente hiperbólico), afastando a possibilidade de se admitir $\phi^{\mathrm{b}}$ constante. Estes resultados concordam com diversos autores: Escário \& Sáez (1987), Delage et al (1987), Fredlund et al (1987), Escário \& Jucá (1989), Röhm \& Vilar (1995).

Outro fato interessante e que atende às observaçõe de, Escário \& Sáez (1987) e Fredlund et al (1987) é que para os dois solos, observou-se um valor inicial para $\phi^{\mathrm{b}}$ 
(calculado através do ângulo de tangência na origem) igual a $\phi$ ' (ângulo de atrito interno efetivo do solo saturado).

Faz-se a seguir uma previsão dos resultados obtidos de acordo com a proposta de Vilar (2003), baseada no modelo hipebólico, que utiliza os parâmetros de resistência do solo saturado e o resultado de um único corpo de prova ensaiado numa determinada sucção, no caso o valor correspondente à máxima sucção (Figura 5.21).

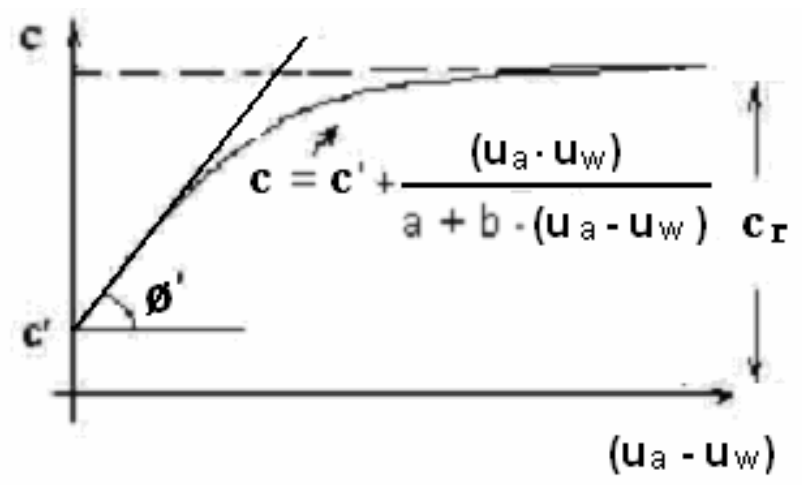

Figura 5.21 - Relação hiperbólica entre sucção $\left(\psi=\mathrm{u}_{\mathrm{a}}-\mathrm{u}_{\mathrm{w}}\right)$ e coesão, utilizada para obtenção dos parâmetros, a e b da previsão.

Admitindo-se que a relação entre a coesão e a sucção matricial $\left(\mathrm{u}_{\mathrm{a}}-\mathrm{u}_{\mathrm{w}}\right)$ seja hiperbólica, de acordo com a equação 5.1 e com a Figura 5.21, tem-se as seguintes hipóteses:

1) O limite da função (5.1) quando a sucção matricial tende ao infinito é igual a $c_{r}$ (definido na Figura 5.22). Com essa hipótese obtêm-se o parâmetro b;

$$
\lim c_{\left(u_{a}-u_{w} \rightarrow \infty\right)}=c_{r}=c^{\prime}+\frac{1}{b} \Rightarrow b=\frac{1}{c_{r}-c^{\prime}}
$$

2) A derivada da função (5.1) quando a sucção tende a zero é igual a tg $\phi$ ' (Figura 5.22). Com essa hipótese obtêm-se o parâmetro a.

$$
\frac{d c}{d \psi}\left(u_{a}-u_{w} \rightarrow 0\right)=\frac{a}{\left[a+b \cdot\left(u_{a}-u_{w}\right)\right]^{2}}=\frac{1}{a}=\operatorname{tg} \phi^{\prime} \Rightarrow a=\frac{1}{\operatorname{tg} \phi^{\prime}}
$$


Na prática a situação usual é ter-se um certo valor $\left(\mathrm{u}_{\mathrm{a}}-\mathrm{u}_{\mathrm{w}}\right)_{\mathrm{m}}$, onde $\left(\mathrm{u}_{\mathrm{a}}-\mathrm{u}_{\mathrm{w}}\right)_{\mathrm{m}}$ é igual a sucção máxima utilizada nos ensaios, da qual obtêm-se a coesão máxima $\left(\mathrm{c}_{\mathrm{m}}=\right.$ $c_{r}$ ). Com isto chega-se ao parâmetro b (equação 5.4) associado a uma determinada sucção de ensaio, no caso $\left(\mathrm{u}_{\mathrm{a}}-\mathrm{u}_{\mathrm{w}}\right)_{\mathrm{m}}$.

$$
c^{\prime}+\frac{\left(u_{a}-u_{w}\right)_{m}}{a+b \cdot\left(u_{a}-u_{w}\right)_{m}}=c_{m} \Rightarrow b=\frac{1}{c_{r}-c^{\prime}}-\frac{a}{\left(u_{a}-u_{w}\right)_{m}} \text { ou } b=\frac{1}{c_{r}-c^{\prime}}-\frac{1}{\operatorname{tg} \phi^{\prime} \cdot\left(u_{a}-u_{w}\right)_{m}}
$$

A Tabela 5.9 apresenta os valores das constantes utilizadas para a previsão da envoltória através da proposta descrita anteriormente.

Tbela 5.9 - Valores adotados na previsão da envoltória da sucção versus coesão.

\begin{tabular}{ccccccc}
\hline solo & $\mathrm{c}^{\prime}(\mathrm{kPa})$ & $\phi^{\prime}($ graus $)$ & $\left(\mathrm{u}_{\mathrm{a}}-\mathrm{u}_{\mathrm{w}}\right)_{\mathrm{m}}(\mathrm{kPa})$ & $\mathrm{c}_{\mathrm{m}}(\mathrm{kPa})$ & $\mathrm{a}$ (previsão) & $\mathrm{b}$ (previsão) \\
\hline jovem & 24 & 28 & 320 & 98,5 & 1,88 & 0,0075 \\
maduro & 19,2 & 31 & 320 & 125,9 & 1,66 & 0,0042 \\
\hline
\end{tabular}

As Figuras 5.22 e 5.23 mostram, respectivamente, para o solo residual jovem e residual maduro, a previsão da curva coesão versus sucção.

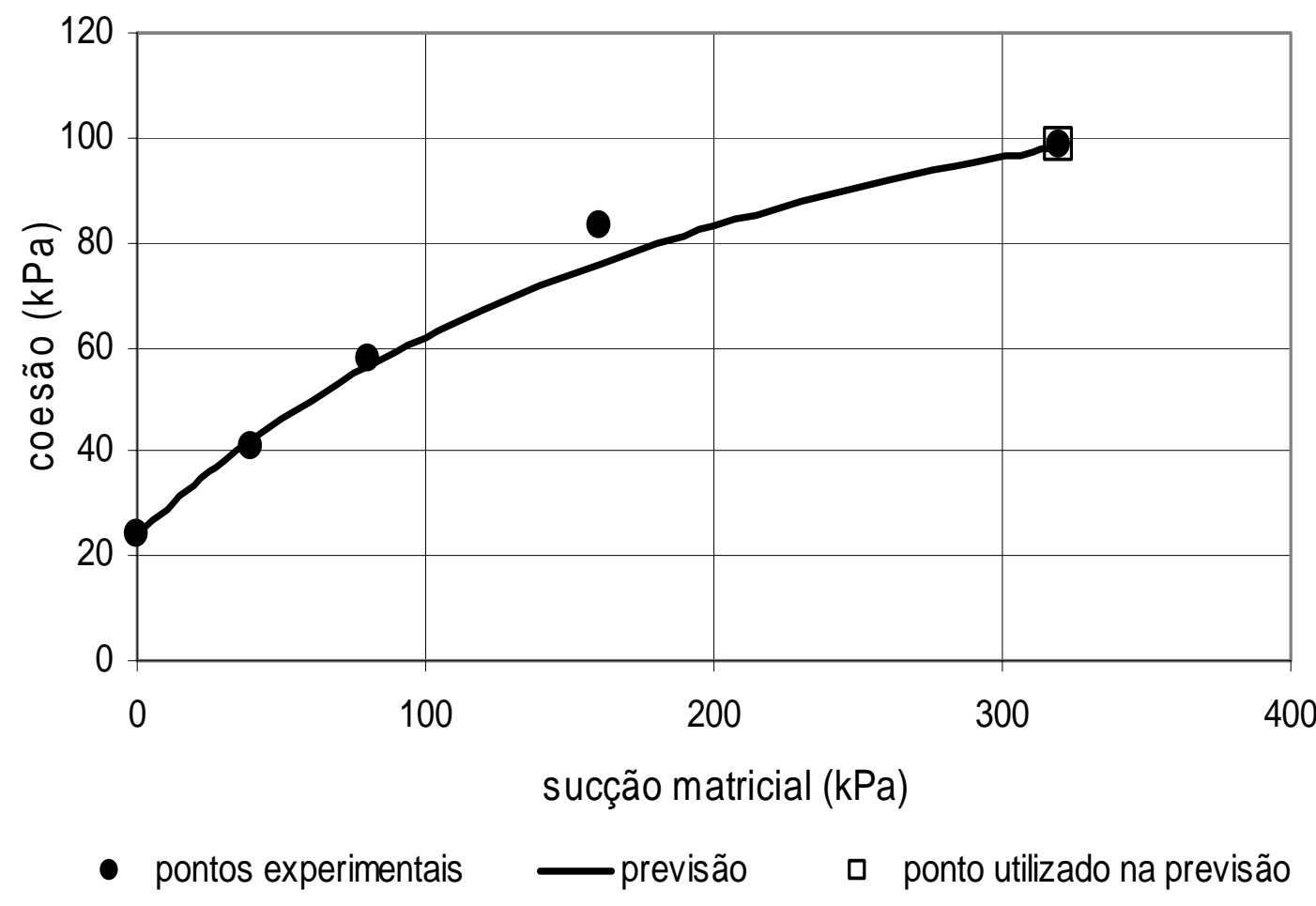

Figura 5.22 - Previsão da variação da coesão em função da sucção para o solo residual jovem. 


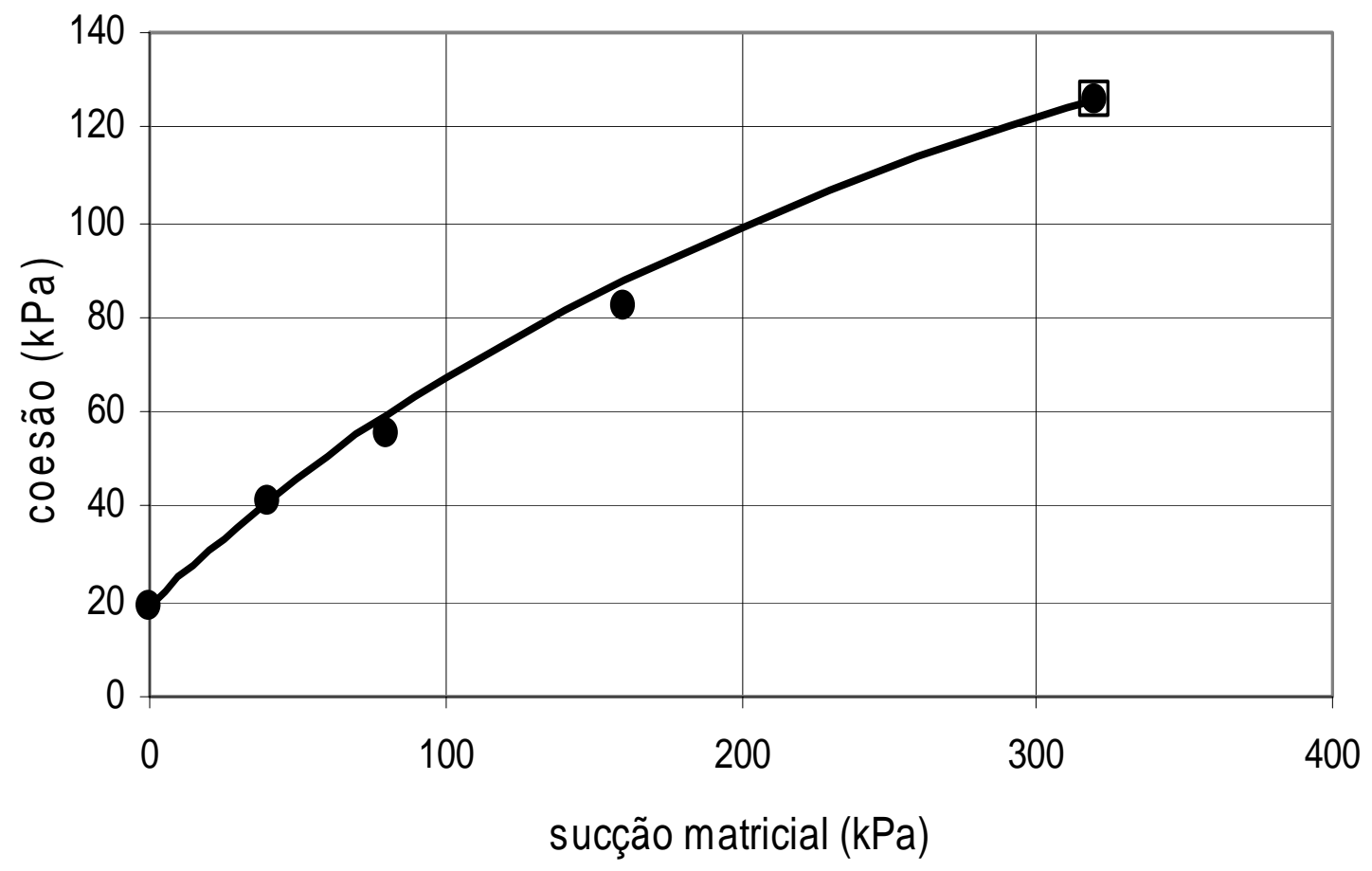

- pontos experimentais — previsão $\quad$ ponto utilizado na previsão

Figura 5.23 - Previsão da variação da coesão em função da sucção para o solo residual maduro.

Em primeiro lugar percebe-se que uma relação não linear (função hiperbólica) ajustou-se bem aos pontos experimentais representando bem a relação entre sucção e coesão, diferentemente da relação linear apresentada por Fredlund (1978). Percebe-se também que o ajuste (função hiperbólica) e a previsão para os dois solos, quando comparados com os pontos experimentais, foram bons e muito próximos, indicando assim que a previsão da envoltória, através do procedimento descrito anteriormente, é válido para os dois solos estudados.

Faz-se agora, uma previsão da envoltória apenas via um conjunto de ensaios saturados, onde c' e $\phi$ ' são obtidos, e um conjunto de ensaios com o corpo de prova seco ao ar até a constância de peso, onde $\left(\mathrm{u}_{\mathrm{a}}-\mathrm{u}_{\mathrm{w}}\right)_{\text {residual }}$ e $\mathrm{c}$ residual são obtidos. Este tipo de previsão é importante, pois evitaria o uso de elementos especiais como pedra porosa de alta entrada de pressão de ar e tornaria a obtenção desta envoltória bem mais simples e também mais rápida. A Tabela 5.10 apresenta os valores das constantes utilizadas para a previsão da envoltória não saturada. 
Tabela 5.10 - Valores de das constantes usadas na previsão da envoltória de resistência não saturada

\begin{tabular}{ccccccc}
\hline solo & $\mathrm{c}^{\prime}(\mathrm{kPa})$ & $\begin{array}{c}\phi^{\prime} \\
\text { (graus) }\end{array}$ & $\mathrm{c}(\mathrm{seco})(\mathrm{kPa})$ & $\begin{array}{c}\varnothing(\mathrm{seco}) \\
(\mathrm{kPa})\end{array}$ & $\mathrm{a}$ (previsão) & $\mathrm{b}$ (previsão) \\
\hline jovem & 24 & 28 & 111,5 & 29,42 & 1,88 & 0,01143 \\
\hline
\end{tabular}

A Figura 5.24 apresenta a previsão da envoltória não saturada utilizando apenas um conjunto de ensaios saturados e não saturados, secos ao ar . A sucção nos corpos de provas secos foi medida através do papel filtro, após a ruptura dos corpos de prova. $\mathrm{O}$ valor da sucção foi por volta de $19900 \mathrm{kPa}$.

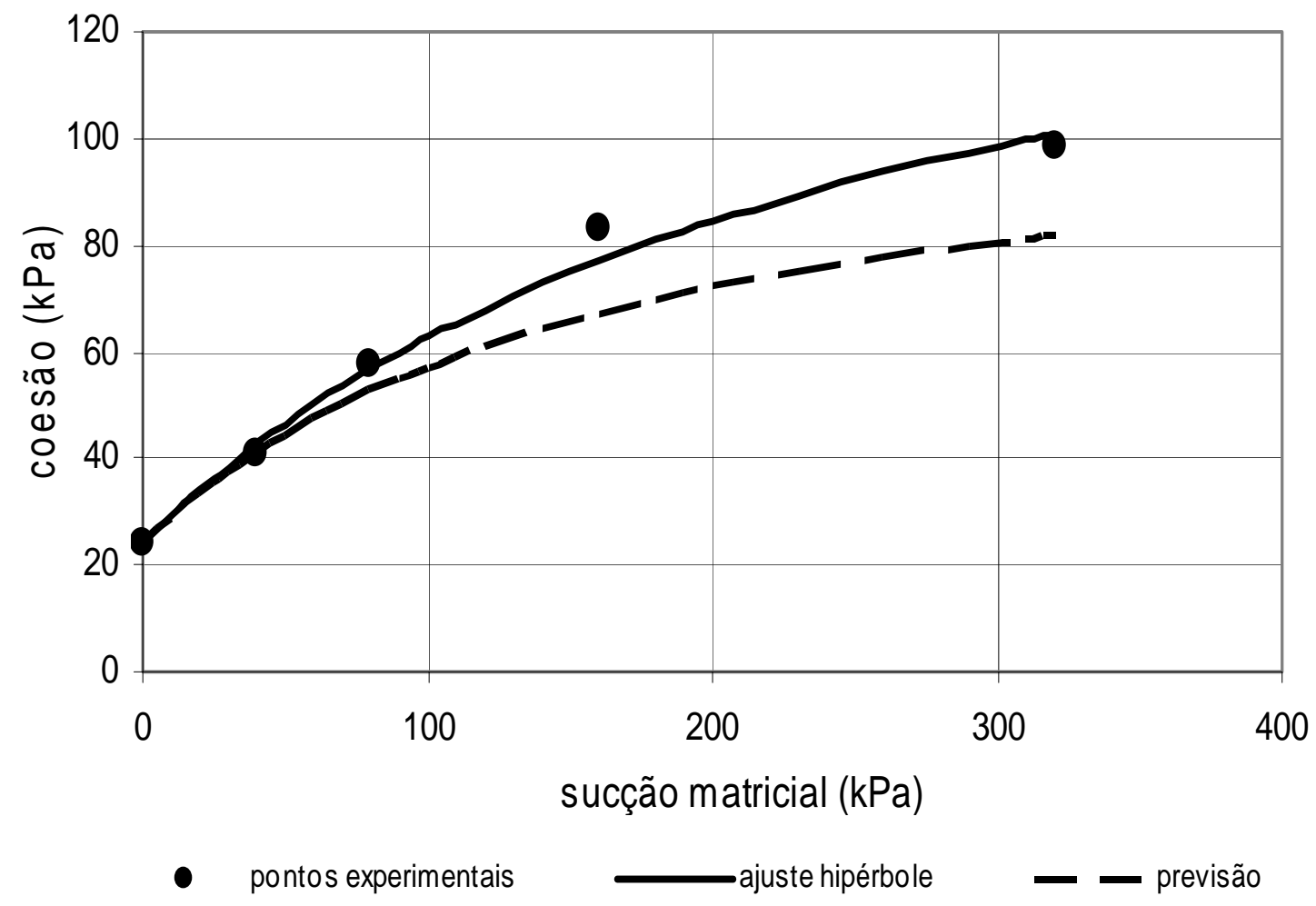

Figura 5.24 - Previsão da envoltória de resistência não saturada através de corpos de provas saturados e secos ao ar.

Percebe-se desta figura que a previsão foi um pouco conservadora. Esta previsão é importante pois pode ser usada, como um ponto de partida, em casos onde não se tem conhecimento da resistência não saturada, de maneira rápida, simples e segura. 


\subsubsection{Curva de plastificação}

Neste item mostra-se o critério adotado para a determinação da tensão de cedência ou de plastificação e fazem-se considerações acerca do ajuste de alguns modelos aos dados experimentais.

\subsubsection{Determinação do Ponto de Cedência (escoamento)}

Os pontos de escoamento nos ensaios de compressão isotrópica, de compressão triaxial convencional e em trajetórias de tensões diferentes da convencional foram determinados usando a aproximação de Graham et al. (1983). Segundo esta aproximação, o ponto de escoamento pode ser definido como uma mudança de inclinação na curva $\mathrm{Sw} x \mathrm{~W}$, onde $\mathrm{Sw}$ é o invariante de tensões definido pela equação 5.5 e W é o trabalho realizado sobre a amostra, calculado utilizando-se a equação 5.6, para um caso de carregamento axissimétrico. A curva de plastificação é obtida pela união dos pontos de escoamento obtidos para os ensaios triaxiais convencionais e não convencionais e também para os ensaios de compressão isotrópica.

$$
\begin{aligned}
& S w=\sqrt{p^{2}+q^{2}} \\
& W=\sum_{i=1}^{n}\left\{\left[\frac{\sigma_{1 i}+\sigma_{1(i+1)}}{2}\right]\left[\varepsilon_{1(i+1)-\varepsilon_{1 i}}\right]+2\left[\frac{\sigma_{3 i+\sigma_{3(i+1)}}}{2}\right]\left[\varepsilon_{3(i+1)}-\varepsilon_{3 i}\right]\right\}
\end{aligned}
$$

A definição dos pontos de plastificação (escoamento) do solo utilizando-se o critério proposto por Graham et al. (1983) e pelo método de pacheco Silva para determinação da tensão de pré-adensamento do solo apresentaram valores próximos um do outro. A Figura 5.25 apresenta a definição da tensão de pré-adensamento do solo para um ensaio de compressão hidrostática, segundo Pacheco Silva, enquanto a Figura 5.26 apresenta um exemplo da definição do ponto de escoamento do solo utilizando-se o procedimento proposto por Graham et al. (1983), para o mesmo ensaio. 


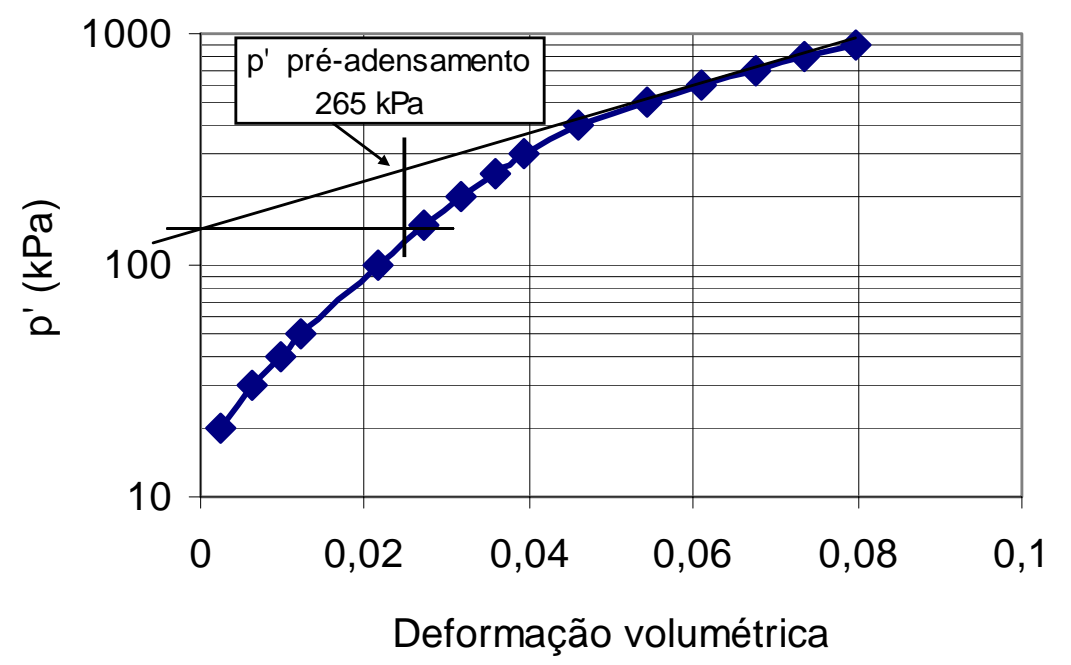

Figura 5.25 - Definição do ponto de escoamento do ensaio de compressão hidrostática, segundo Pacheco Silva.

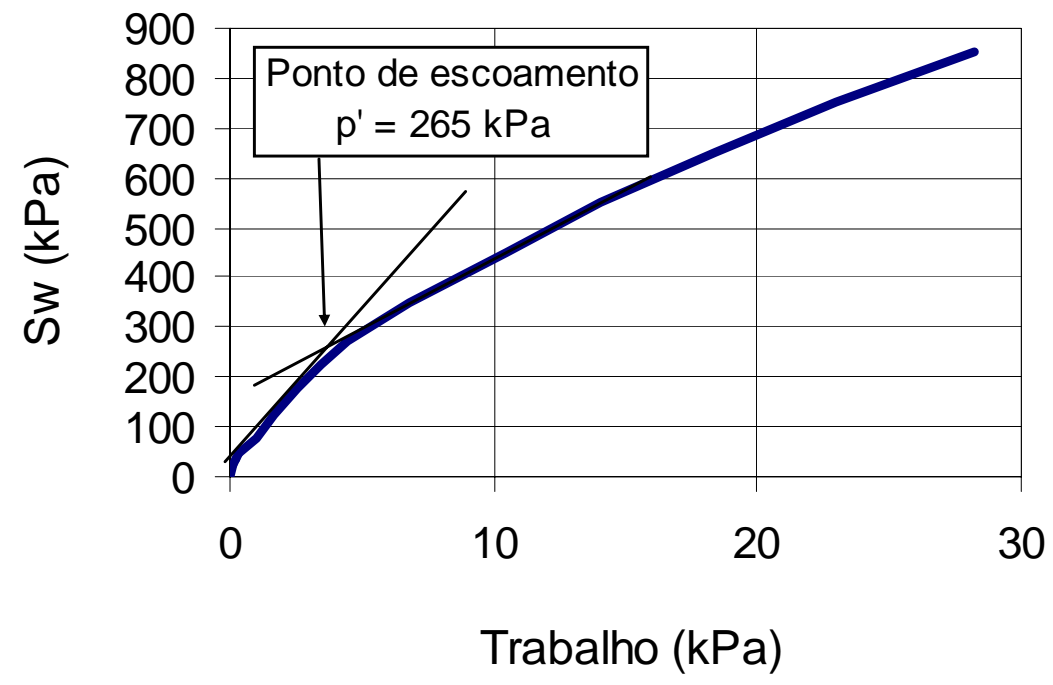

Figura 5.26 - Definição do ponto de escoamento do ensaio de compressão hidrostática, segundo o procedimento de Graham et al. (1983).

\subsubsection{Definição dos parâmetros elásticos}

Para cada ensaio, o módulo de elasticidade foi definido a partir da tensão desviadora e da deformação axial correspondente ao ponto de cedência (escoamento). $\mathrm{O}$ segundo parâmetro elástico, o coeficiente de Poisson foi assumido constante e igual a 0.15 para todos os ensaios. Estes parâmetros elásticos são necessários para calcular as deformações axiais e radiais elásticas e consequentemente as deformações axiais e radiais plásticas. 


\subsubsection{Parâmetro de encruamento}

Parâmetro através do qual obtêm-se as diversas curvas de plastificação do solo, ou seja, obtêm o encruamento do solo (evolução das curvas de plastificação desde o início da plastificação, parâmetro igual à zero, até a ruptura do solo). Um modo de avaliar possíveis mudanças na forma da curva de plastificação do solo com a evolução do encruamento é vincular a forma da curva de plastificação do solo à forma dos contornos de igual trabalho plástico. Este procedimento já foi adotado por Lade e Kim (1988). Estes autores admitem que as curvas de escoamento do solo correspondem às curvas de igual trabalho plástico. O trabalho plástico é definido pela equação 5.7 .

$W_{p}=\int \sigma_{1 \text { médio }} \cdot d \varepsilon_{1}^{p}+\int \sigma_{2 \text { médio }} \cdot d \varepsilon_{2}^{p}+\int \sigma_{3 \text { médio }} \cdot d \varepsilon_{3}^{p}$

Nesta expressão $\sigma_{1}$ é a tensão principal maior média atuante no intervalo considerado, $\sigma_{2}=\sigma_{3}$ são as tensões principais intermediária e menor que no caso de ensaio realizado na trajetória convencional é o próprio confinamento aplicado e no caso de trajetórias diferentes da convencional é a tensão média atuante no intervalo considerado.

$d \varepsilon_{1}^{p}, d \varepsilon_{2}^{p}=d \varepsilon_{3}^{p}$ são respectivamente os acréscimos de deformação axial plástica e deformação radial plástica.

Na Figura 5.27 tem-se uma curva $\sigma$ x $\varepsilon$ genérica. Para um dado valor de $\sigma_{1}-\sigma_{3}$ tem-se uma deformação total $\varepsilon_{1}^{t}$ composta da deformação elástica, $\varepsilon_{1}^{e}$ e da deformação plástica, $\varepsilon_{1}^{p}$, de acordo com a propriedade aditiva das deformações (equação 5.8):

$$
\varepsilon_{1}^{t}=\varepsilon_{1}^{e}+\varepsilon_{1}^{p}
$$

Conhecendo-se o módulo de elasticidade, pode-se calcular $\varepsilon_{1}^{e}$ pela equação 5.9 e a partir daí $\varepsilon_{1}^{p}$ pela equação 5.10 . 


$$
\begin{aligned}
& \varepsilon_{1}^{e}=\left(\sigma_{1}-\sigma_{3}\right) / E \\
& \varepsilon_{1}^{p}=\varepsilon_{1}^{t}-\varepsilon_{1}^{e}
\end{aligned}
$$

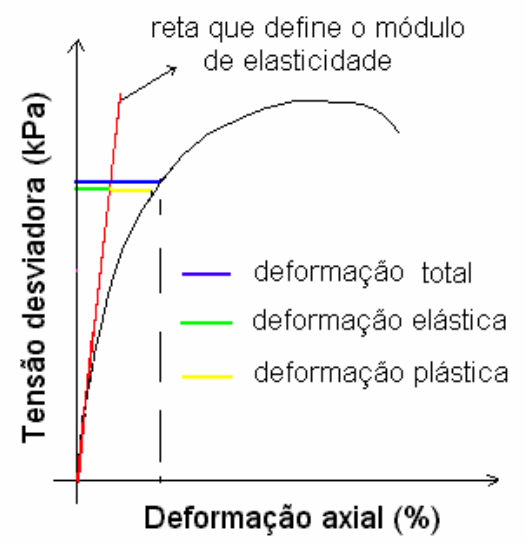

Figura 5.27 - Definição das deformações axiais, elásticas e plásticas, ao longo da curva tensãodeformação.

A definição da deformação radial elástica, $\varepsilon_{2}^{e}=\varepsilon_{3}^{e}$, é feita pela equação 5.11 que é baseada no conceito básico do coeficiente de Poisson.

$$
\varepsilon_{2}^{e}=\varepsilon_{3}^{e}=-\left(v \cdot \varepsilon_{1}^{e}\right)
$$

Para o cálculo da deformação radial plástica, $\varepsilon_{2}^{p}=\varepsilon_{3}^{p}$, é necessário o cálculo da deformação volumétrica plástica, $\varepsilon_{V}^{p}$, que é definida pela equação 5.12 , na qual a deformação volumétrica elástica, $\varepsilon_{V}^{e}$, é definida pela equação 5.13. Uma vez calculada $\varepsilon_{V}^{p}$, calcula-se $\varepsilon_{3}^{p}$ através da equação 5.14 .

$$
\begin{aligned}
& \varepsilon_{v}^{p}=\varepsilon_{v}^{t}-\varepsilon_{v}^{e} \\
& \varepsilon_{v}^{e}=\varepsilon_{1}^{e}+2 \cdot \varepsilon_{3}^{e}
\end{aligned}
$$


$\varepsilon_{3}^{p}=\varepsilon_{2}^{p}=\left(\varepsilon_{v}^{p}-\varepsilon_{1}^{p}\right) / 2$

A Figura 5.28, representa os dois tipos possíveis de deformação volumétrica plástica que foram encontradas nos ensaios realizados. Dependendo do confinamento, as deformações volumétricas plásticas foram de expansão ou de compressão.

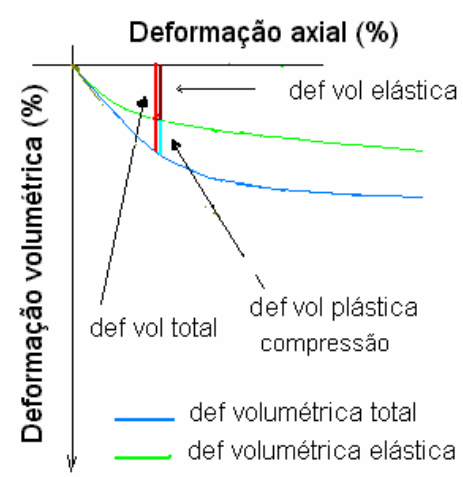

a

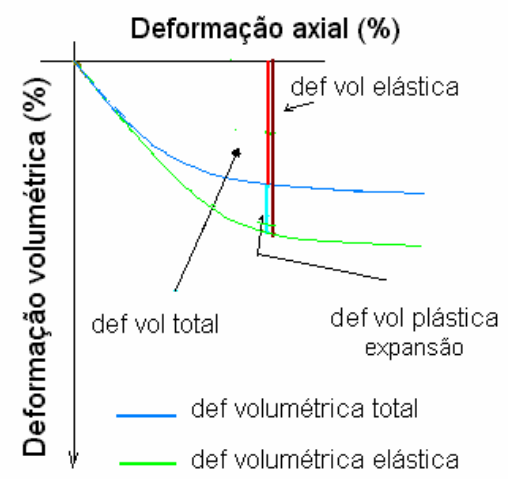

b

Figura 5.28 - Tipos possíveis de deformações volumétricas plásticas encontradas nos ensaios realizados: $\mathrm{a}$ - compressão, $\mathrm{b}$ - expansão.

Uma vez determinadas as diferentes deformações, procede-se ao cálculo do acréscimo de trabalho plástico, ao longo do ensaio, para cada intervalo de tensão considerado. Em primeiro lugar calculam-se os acréscimos de deformação axial plástica, $d \varepsilon_{1}^{p}$ (equação 5.15), e os acréscimos de deformação radial plástica, $d \varepsilon_{2}^{p}=d \varepsilon_{3}^{p}$. Pode - se então calcular os acréscimos de trabalho plástico, $d w_{p}$, através da equação 5.16, que é a equação 5.7 discretizada.

$$
\begin{aligned}
& d \varepsilon_{1(i)}=\varepsilon_{1(i)}^{p}-\varepsilon_{1(i-1)}^{p} \\
& \left.d W_{p(i)}=\left\{\left(d \varepsilon_{1(i)}^{p}-d \varepsilon_{1(i-1)}^{p}\right) \cdot\left(\left(\sigma_{1(i)}+\sigma_{1(i-1)}\right) / 2\right)\right]+\left[2 \cdot\left(d \varepsilon_{3(i)}^{p}-d \varepsilon_{3(i-1)}^{p}\right) \cdot\left(\left(\sigma_{3(i)}+\sigma_{3(i-1)}\right) / 2\right)\right]\right\}
\end{aligned}
$$


O trabalho plástico é determinado, pela equação 5.17, para cada par p, q ou q/2 ao longo do ensaio até a ruptura, onde p é obtido pela equação 5.18 e q é obtido pela equação 5.19 .

$$
\begin{aligned}
& W_{p(i)}=\sum_{i=1}^{i=n}\left(d W_{p(i)}\right) \\
& \mathrm{p}=\frac{\sigma 1+2 . \sigma 3}{3} \\
& q=\sigma 1-\sigma 3
\end{aligned}
$$

Finalmente curvas passando pelos pontos definidos por $\mathrm{p}, \mathrm{q}$ ou q/2 que tem o mesmo valor do parâmetro de encruamento (trabalho plástico) são plotadas.

\subsubsection{Solo Jovem (saturado)}

A Figura 5.29 apresenta o ajuste da equação 2.12 (Cam Clay modificado) aos dados experimentais calculados utilizando-se os resultados dos ensaios triaxiais convencionais, triaxiais não convencionais e compressão hidrostática realizados no solo residual saprolítico saturado. $\mathrm{O}$ coeficiente de determinação obtido foi de $\mathrm{r}^{2}=0.88$. Neste ajuste foi adotado um valor de $\mathrm{M}=1,20$ correspondente a um ângulo de atrito de $30^{\circ}$, calculado utilizando-se os resultados dos ensaios triaxiais convencionais saturados, para o solo saprolítico, forçando-se a obtenção de um intercepto de coesão nulo. O valor de $\mathrm{p}_{0}$ usado, foi obtido através do ensaio de compressão hidrostática e seu valor foi de $265 \mathrm{kPa}$. 


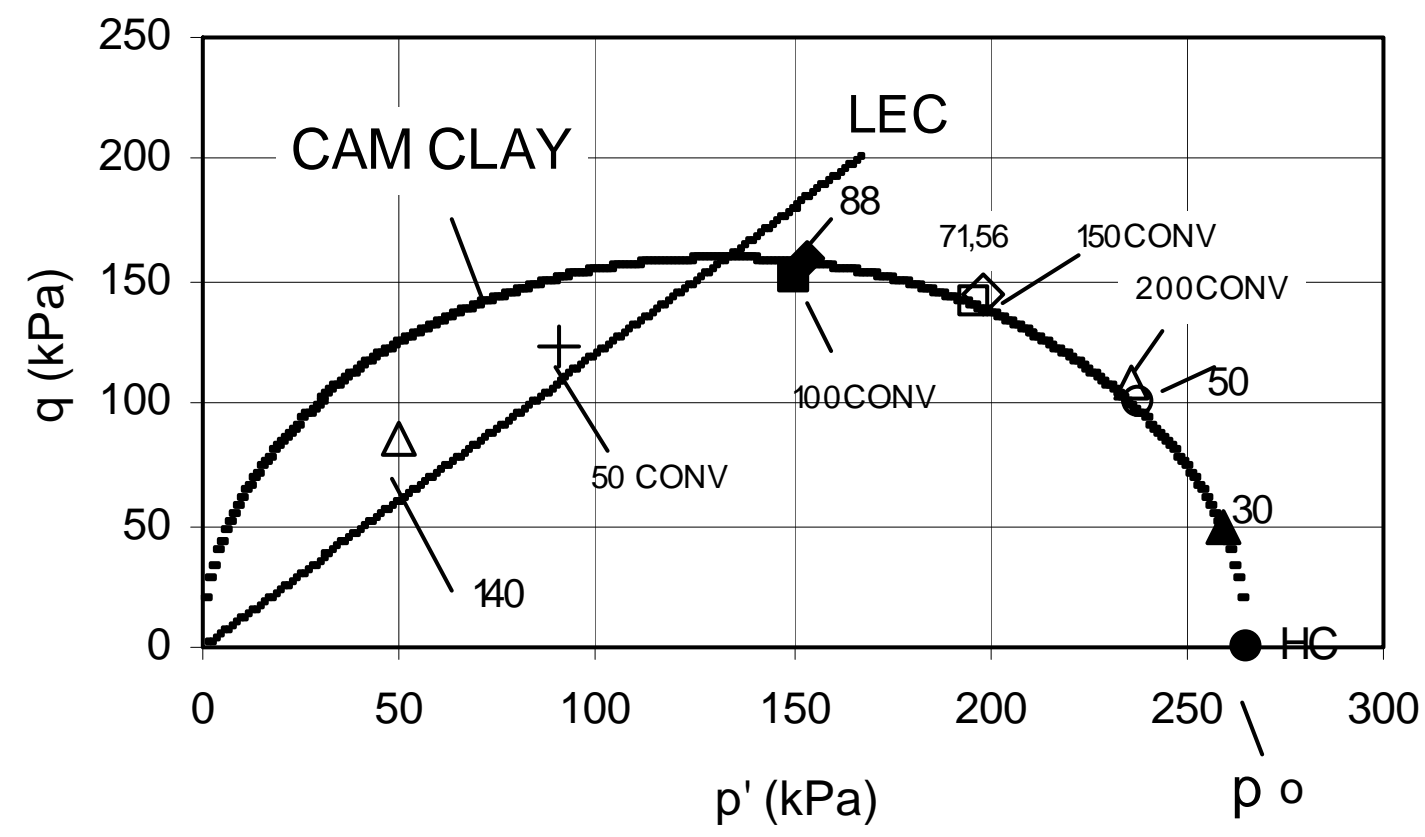

Figura 5.29 - Ajuste da equação 2.12 (Cam Clay modificado), aos dados experimentais.

Conforme apresentado na Figura 5.29, há um ajuste razoável da equação 2.12 aos dados experimentais. Nota-se ainda que a equação 2.12 se ajusta melhor aos dados experimentais situados à direita da projeção da linha de estados críticos, havendo uma super estimativa dos valores de plastificação do solo para o caso das amostras com alto valor de OCR na ruptura.

A Figura 5.30 apresenta o encruamento do solo residual jovem saturado ensaiado na direção vertical de acordo com o procedimento descrito anteriormente. 


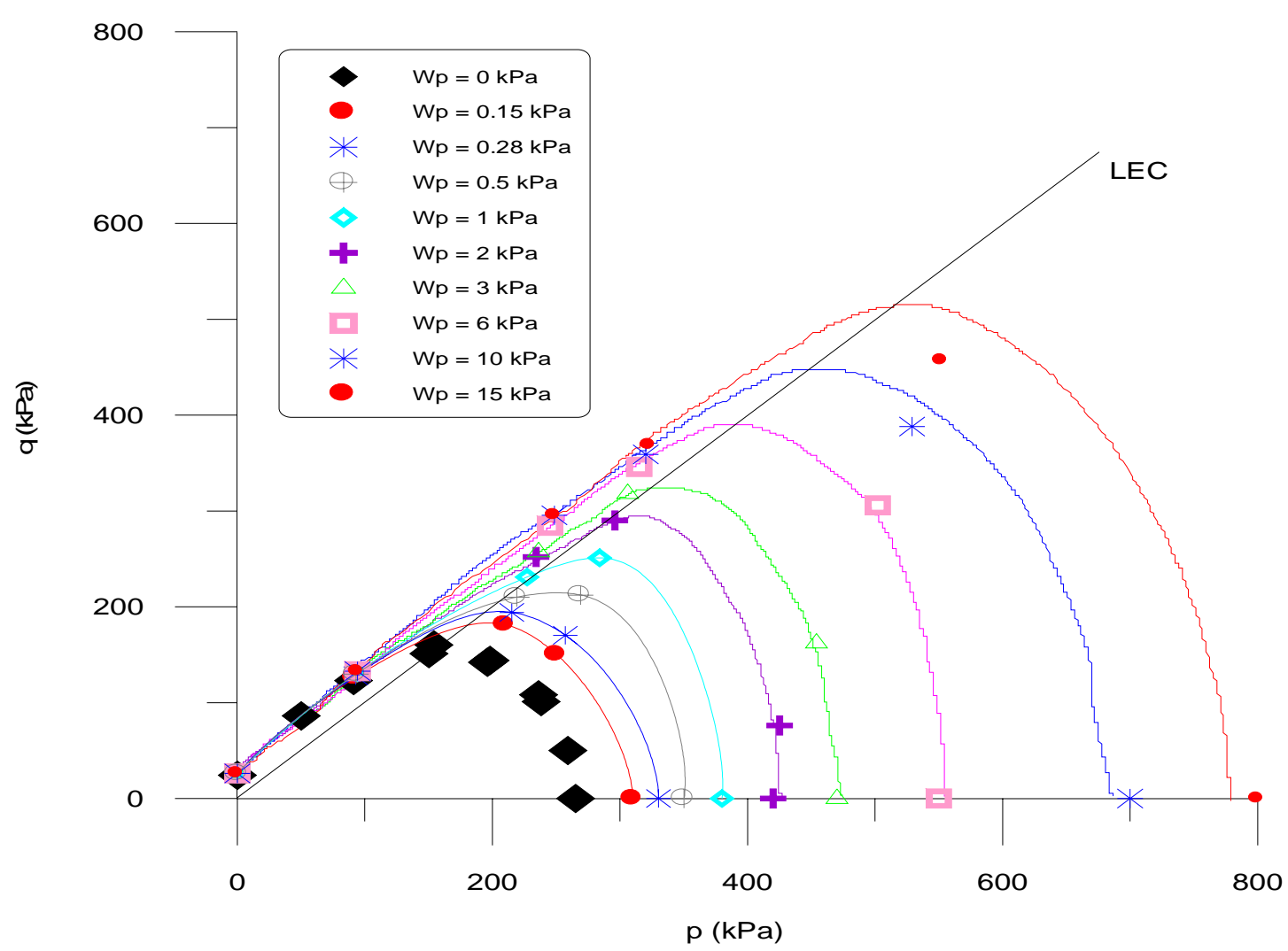

Figura 5.30 - Contornos de trabalho plástico obtidos em ensaios realizados em amostras saturadas.

\subsubsection{Solo não saturado com sucção controlada}

Nos ensaios com controle de sucção buscou-se determinar, no solo jovem, as curvas de escoamento para as sucções adotadas, através dos pontos de escoamento dos ensaios triaxiais e dos ensaios de compressão hidrostática, e compará-las com a equação do modelo de Alonso et al.(1990). Buscou-se também, obter as superfícies LC e Ps e prever a superfície Ps através da curva coesão versus sucção matricial obtida dos ensaios triaxiais.

Para uma análise das formas das superfícies de plastificação, em uma primeira instância, os valores de ps, representados na equação 2.14 , foram obtidos ajustando-se aos dados experimentais, pontos de escoamento dos ensaios triaxiais e $\mathrm{p}_{0}$ (obtido do ensaio de compressão hidrostática), esta equação pelo processo dos mínimos quadrados.

A Figura 5.31 ilustra a superfície de escoamento ajustada aos dados experimentais, conservando-se o valor de $\mathrm{M}=1,20$, para os ensaios realizados com valor de sucção constante e igual a $80 \mathrm{kPa}$. Nesta figura, também são apresentados o valor de po, obtido do ensaio de compressão hidrostática e usado no ajuste juntamente com os pontos de escoamento dos ensaios triaxiais, o valor de ps obtido através do ajuste e o 
valor do coeficiente de determinação correspondente. A Figura 5.32 mostra o espraiamento das curvas de escoamento com a sucção, para os ensaios realizados com valores de sucções constantes e iguais a $0,80,160,320 \mathrm{kPa}$

Os valores de ps obtidos, para as sucções ensaiadas, através do ajuste feito aos dados experimentais, utilizando a equação 2.14 conforme mostrado na figura 5.31, juntamente com os valores de po (obtidos dos ensaios de compressão hidrostática) estão apresentados na Tabela 5.11 .

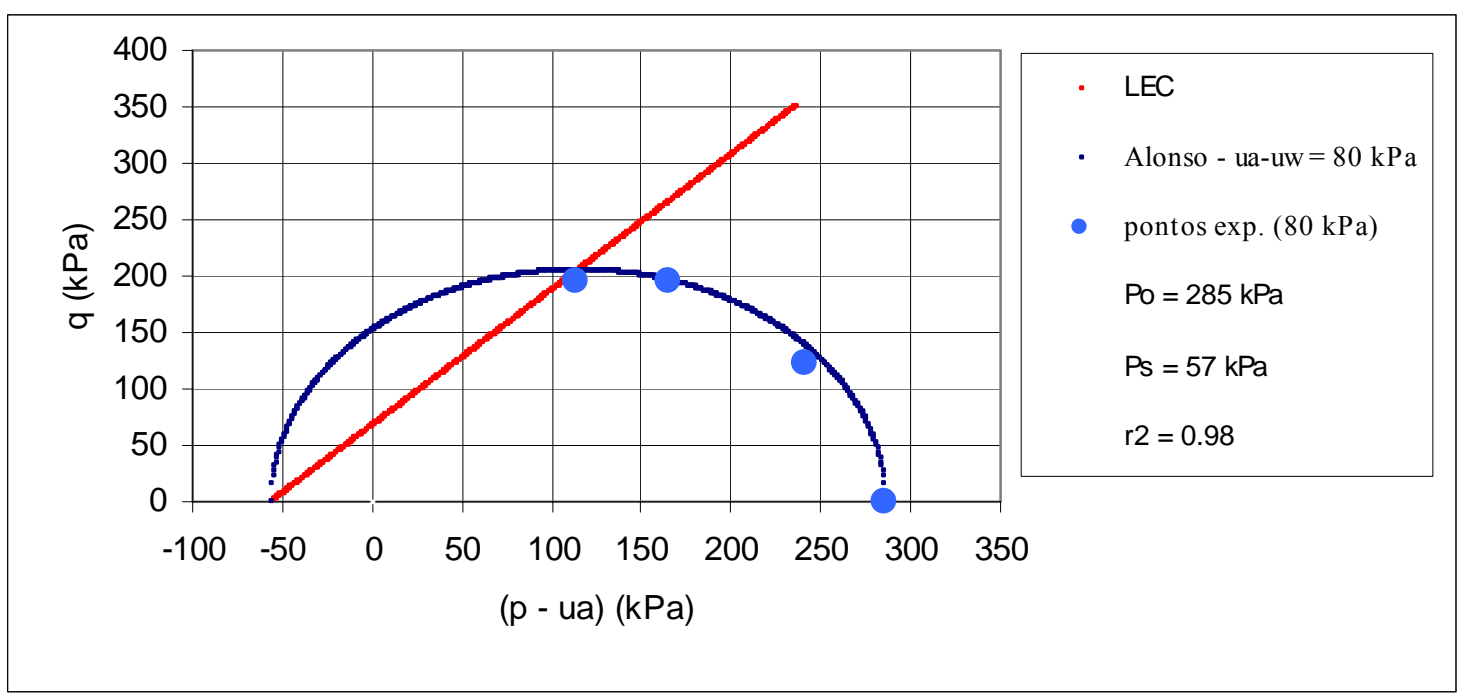

Figura 5.31 - Pontos de escoamento obtidos e ajustados pela equação 2.14, para os ensaios realizados com sucção igual a $80 \mathrm{kPa}$. 


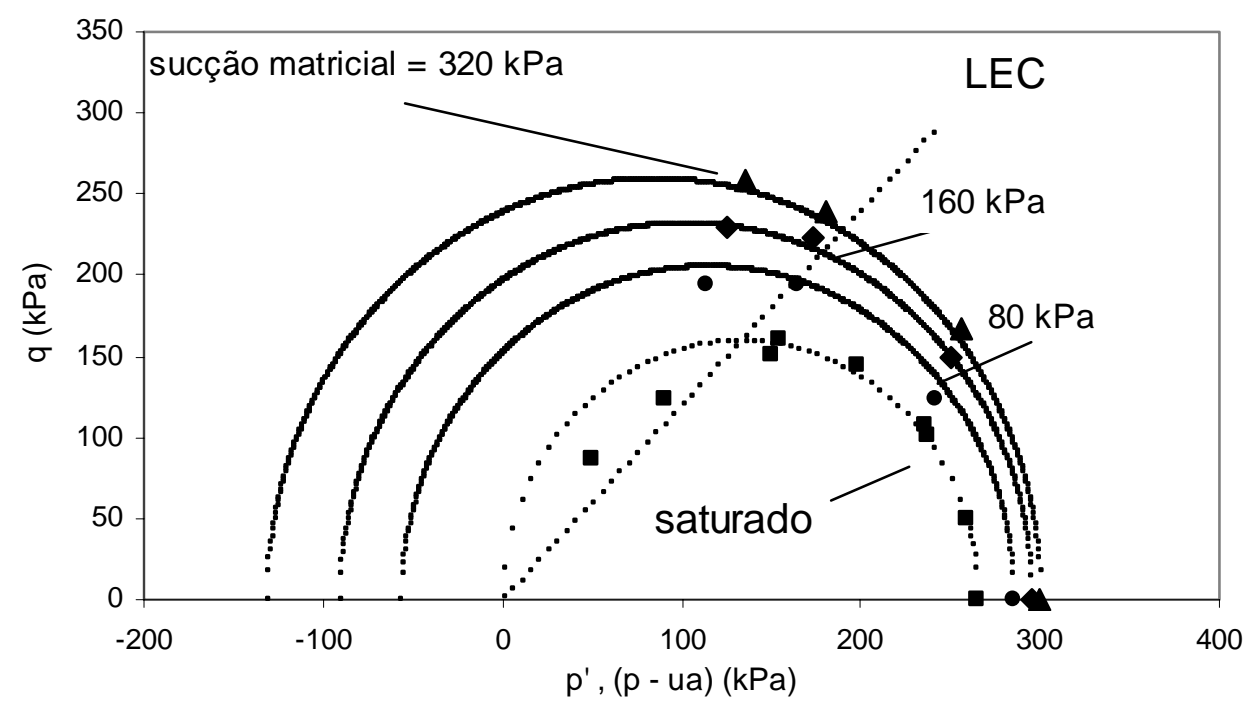

Figura 5.32 - Variação da curva de plastificação com a sucção.

Tabela 5.11 - Valores de $\mathrm{p}_{\mathrm{s}}$ e de $\mathrm{p}_{\mathrm{o}}$ obtidos, conforme Figuras 5.29, através do ajuste da equação 2.14 aos dados experimentais.

\begin{tabular}{|c|c|c|}
\hline Sucção $(\mathrm{kPa})$ & Ps $(\mathrm{kPa})$ & Po $(\mathrm{kPa})$ \\
\hline 0 & 0 & 265 \\
\hline 80 & 57 & 285 \\
\hline 160 & 91.4 & 295 \\
\hline 320 & 132 & 300 \\
\hline
\end{tabular}

O espraiamento da superfície Ps com a sucção poderia ser estimado através da curva coesão versus sucção matricial (hiperbólica) obtida dos ensaios triaxiais. No modelo de Alonso et al. (1990), Ps(s) é admitida como função linear da sucção. Deve-se salientar contudo, que isto implica adotar uma relação linear entre a coesão e a sucção matricial, o que, segundo os próprios autores, não é válido para muitos dos solos. A partir dos resultados obtidos de ensaios triaxiais realizados em amostras saturadas e com controle de sucção, obteve-se um bom ajuste aos dados experimentais relacionando-se a coesão do solo com a sucção matricial através de uma relação hiperbólica (equação 5.1), já apresentada anteriormente. Os parâmetros de ajuste encontrados para a equação 5.1, já mostrados anteriormente, foram: $\mathrm{c}^{\prime}=24, \mathrm{a}=1.86 \mathrm{e} \mathrm{b}=0.0072 \mathrm{kPa}^{-1}$, o que conduziu a obtenção de um $r^{2}=0.94$.

Para que a equação 5.1 seja transformada na função Ps(s), é necessário que se estabeleça uma relação entre os valores de c' obtidos em termos de $\tau$ e $\sigma$ e os valores de 
$\mathrm{c}^{*}$, obtidos em termos de q e p. Pode-se mostrar que uma envoltória de ruptura no espaço (q;p), para valores não nulos de coesão seria dada pela equação 5.20, apresentada adiante:

$$
q=c^{*}+M \cdot p
$$

Onde: $M=\frac{6 \cdot \operatorname{sen} \phi}{3-\operatorname{sen} \phi}$ e $\quad c^{*}=\frac{M . c}{\tan \phi}$

Para a definição da função Ps(s), deve-se levar em conta ainda o fato de que esta deve satisfazer a condição $\mathrm{ps}(\mathrm{o})=0$, já que o próprio modelo, através de sua superfície de escoamento, deve levar em conta a coesão obtida pelo solo devido ao seu préadensamento. Além do mais, nota-se que $\operatorname{Ps}(s)=c^{*}(s) / M$, o que faz com que a função Ps(s) seja dada pela equação 5.21:

$$
p_{s}(s)=\frac{u_{a}-u_{w}}{a+b . .\left(u_{a}-u_{w}\right)} \cot a n \phi
$$

A Tabela 5.12 apresenta os valores de ps obtidos pela equação 5.21, para as sucções ensaiadas. Nesta equação o valor de $\phi=30^{\circ}$, corresponde ao ângulo de atrito dos ensaios saturados ajustado pela origem.

Tabela 5.12 - Valores de ps previstos pela equação 5.21.

\begin{tabular}{|c|c|}
\hline Sucção $(\mathrm{kPa})$ & $\operatorname{Ps}(\mathrm{s})(\mathrm{kPa})$ \\
\hline 80 & 56.5 \\
\hline 160 & 91.4 \\
\hline 320 & 132 \\
\hline
\end{tabular}

A figura 5.33 mostra a superfície ps(s) prevista pela equação 5.21 e a obtida experimentalmente, juntamente com a superfície LC. 


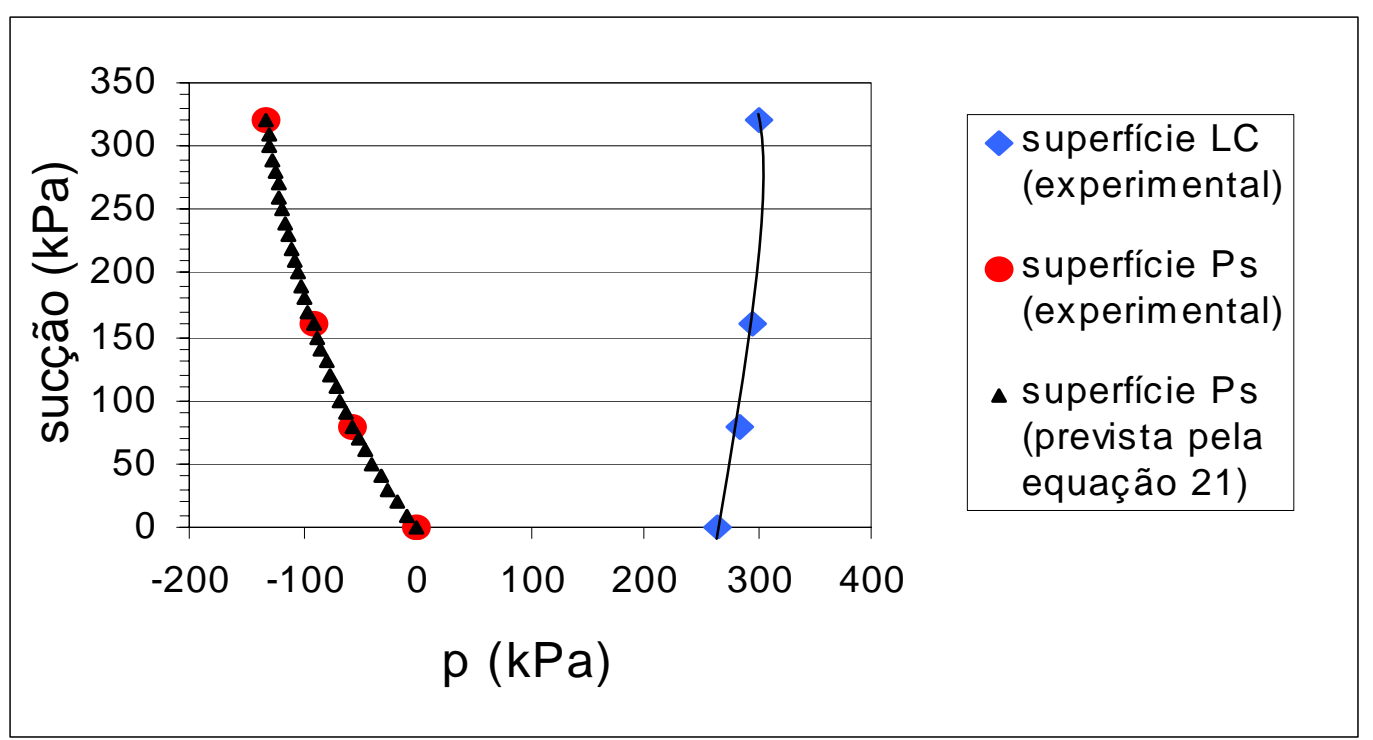

Figura 5.33 - Superfície Ps(s) prevista e experimental, juntamente com a superfície LC.

Percebe-se desta figura que as duas superfícies (ps) são praticamente idênticas, mostrando assim que as curvas de escoamento do material podem ser previstas através dos ensaios de compressão hidrostática, utilizando a tensão de pré-adensamento isotrópica (po), e dos ensaios de compressão triaxial, utilizando a curva coesão versus sucção matricial. A Figura 5.31 mostra ainda, que o efeito da sucção na tensão de préadensamento isotrópica é pequeno (curva LC) sugerindo assim que o solo não seja colapsível, enquanto que na resistência o efeito já é bem maior (curva Ps). 


\section{CONCLUSÕES}

Este trabalho investigou o comportamento mecânico de dois horizontes de um solo residual de gnaisse, típico da região de Viçosa-MG, um mais superficial, correspondente a um solo residual maduro, e outro, mais profundo correspondente a um solo residual jovem. A partir dos resultados experimentais apresentados e das análises realizadas pode-se chegar as seguintes conclusões:

1. As composições mineralógicas destes solos, permitem aferir que existi um relacionamento genético destes dois horizontes. As informações mineralógicas confirmam os resultados da classificação MCT que enquadra o solo maduro como Laterítico (LG' - laterítico argiloso), e o solo jovem como não laterítico (NS' - não laterítico siltoso).

2. A facilidade de trabalho com estes solos, no que diz respeito à saturação e ao equilíbrio de sucção é devida a predominância de macroporos.

3. A microestrutura do solo maduro é comandada pelos microagregados ovóides cimentados (presença de goethita e gibsita confirmada pela análise mineralógica) muito propícia a rearranjos microestruturais, e que se mostra heterogênea e anisotrópica como um todo. A microestrutura do solo jovem é comandada pelos pseudomorfos de biotita. Estes são altamente compressíveis, de uma maneira praticamente similar independente da direção de carregamento, devido ao alto grau de intemperismo, e estão dispersos no solo jovem de uma forma caótica sugerindo assim um material sem estruturação significante em nível da microestrutura. Esta microestrutura, baseada nas características dos pseudomorfos, parece ser muito mais homogênea e isotrópica quando comparada com a microestrutura do solo maduro (laterítico). 
4. Quanto ao estudo da anisotropia realizado pode-se concluir que:

- O solo jovem apresentou comportamento isotrópico quanto à resistência, independente do nível de deformação axial e praticamente isotrópico quanto à deformabilidade para os níveis de deformações axiais analizados;

- O solo maduro apresentou comportamento isotrópico quanto à resistência e comportamento anisotrópico quanto à deformabilidade;

5. Quanto aos ensaios não saturados com controle de sucção realizados, para os dois solos, verificou-se que:

- O ângulo de atrito interno praticamente não variou com a sucção matricial;

- A variação do intercepto de coesão em relação à sucção pode ser representada por uma função hiperbólica;

- O modelo hiperbólico mostra-se como um modelo promissor no que se refere à previsão da curva coesão aparente versus sucção matricial. A proposta de Vilar (2003), mostrou-se mais adequada ao adotar como sucção máxima, uma sucção próxima do ponto de inflexão da curva coesão versus sucção matricial (experimental) e mais conservadora quando se adota a sucção correspondente ao corpo de prova seco (sucção altíssima).

6. Quanto ao grau de intemperismo percebeu-se, no solo maduro que a presença de agentes cimentantes criados pelo processo de intemperismo, e também o tipo de microestrutura, onde se percebe uma tendência a rearranjos, lhe conferiu uma resistência similar ao do solo jovem, tanto em condições saturadas como em condições não saturadas.

7. Quanto à curva de plastificação verificou-se que:

- A curva de plastificação obtida para o solo jovem saturado, devida a sua história de carregamento em campo, possui forma tal que pode ser representada razoavelmente bem 
pela curva de plastificação adotada nos modelos derivados da mecânica dos solos dos estados críticos (Cam-Clay modificado). Conforme apresentado, estas curvas tendem a superestimar o valor da resistência ao cisalhamento de pico de amostras altamente préadensadas. A curva de plastificação apresentou um formato típico de material isotrópico: centrada e perpendicular ao eixo hidrostático.

- As formas dos contornos de igual trabalho plástico parecem ser um bom indicativo das demais curvas de plastificação do solo. A forma da curva de plastificação do solo saturado parece não se alterar de maneira significativa durante o encruamento do solo (endurecimento isotrópico).

- A curva de plastificação para o solo jovem não saturado, em uma determinada sucção, pode ser representada razoavelmente bem pela curva de plastficação adotada no modelo de Alonso et al (1990).

- A forma da curva de plastificação, para o solo jovem, parece não se alterar com o aumento da sucção matricial.

- O efeito da sucção na superfície LC é muito pequeno, sugerindo que os dois solos não sejam colapsíveis, enquanto na resistência já é considerável (superfície Ps).

- O espraiamento da superfície Ps do solo jovem pôde ser previsto pela curva coesão versus sucção matricial obtida dos ensaios triaxiais realizados com controle de sucção.

8. Quanto às recomendações para trabalhos futuros tem-se:

- Um estudo mais detalhado da microestrutura dos solos residuais, através, principalmente, da análise de uma determinada quantidade de amostras ao microscópio eletrônico de varredura e microscópio ótico aliadas a ensaios mecânicos em corpos de prova indeformados e compactados. Este tipo de estudo aplicado a solos residuais derivados de diferentes rochas matrizes com certeza ajudaria em se ter um entendimento geral do comportamento de solos residuais. 
- Quanto à anisotropia chegou-se à conclusão que para solos residuais jovens, com os bandamentos da rocha presentes, porém em avançado estágio de intemperismo o comportamento é praticamente isotrópico. Pode-se então explorar o comportamento de um solo jovem (mais perto da rocha) onde o grau de intemperismo seja pequeno, com pequena porcentagem de silte e areia.

- Quanto à previsão da envoltória de resistência não saturada, recomenda-se o emprego da proposta apresentada neste trabalho a diferentes tipos de solos, com intuito de se chegar a uma forma geral para a previsão da envoltória de resistência de solos não saturados.

- Quanto à parte pertinente a modelos pode-se realizar um estudo que se inicie a partir das curvas de plastificações, como as geradas neste trabalho, e explore a parte voltada à modelagem de solos, determinando assim o tipo de lei de fluxo, a superfície pontencial plástico se precisar, com objetivo de se elaborar um modelo para estes solos. 


\section{REFERÊNCIAS BIBLIOGRÁFICAS}

AAS, G. "A Study of the Effect of Vane Shape and Rate of Strain on the Measured Values of In Situ Shear Streght of Clays", Proc. $6^{\text {th }}$ Int. Conf,, International Conference on Soil Mechanics and Foundation Engineering (ICSMFE), Montreal, Canada, Vol.1, pp. 141-145, 1965.

ABRAMENTO, M. Resistência ao cisalhamento de solos não saturados: Considerações teóricas e estudo experimental. Dissertação de Mestrado. Escola Politécnica da USP, São Paulo - SP, 1988.

ABRAMENTO, M. and CARVALHO, C. S. Geotechnical parametres for study of natural solopes instabilization at "Serra do Mar", Brazil. In: International Conference on Soil Mechanics and Foudation Engineering, 12., Rio de Janeiro, 1989. Proceedings. Rotterdam, Balkema, Vol.2, pp. 1599 - 1602, 1989.

ALEIXO, M. S. "Comportamento Tensão - Deformação de Solos Residuais no Equipamento Triaxial Cúbico”. Dissertação de Mestrado, PUC-Rio, Rio de Janeiro, 1998.

ALONSO, E. E.; GENS, A. and HIGHT, D. W. Special problems soils. General Report. In: European Conference on Soil Mechanics and Foudation Engineering, Dublin, 1987.

ALONSO E. E.; GENS, A. and JOSA, A. A constitutyve model for partly satureted soils. Geotechnic 40 (3), 1990.

ARTHUR, J. R. F. and ASSADI, A. "Ruptured sand sheared in plain strain”, Int. Conf. Soil Mech. Found. Eng. 9, Tokyo, Japan. Proc. Tokyo, pp. 19 - 22, 1977.

ARTHUR, J. R. F.; BEKENSTEIN, S.; GERMAINE, J. T. and LADD, C. C. Stress path tests with controlled rotation of principal stress direction. S. l. : ASTM, pp. 516-540, 1981. (ASTM-Special Technical Publication, 740).

ARTHUR, J. R. F.; CHUA, K. S. and DUNSTAN, T. Induced anisotropy in a sand. Geotechnique, v. 27, n.1, pp.13-36, 1977.

ARTHUR, J. R. F.; CHUA, K. S. and DUNSTAN, T. Principal stress rotation : a missing parameter. Journal of the Geotech. Eng. Div., ASCE, v.106, n. GT4, pp. 419 $-433,1980$. 
ARTHUR, J. R. F. and MENZIES, B. K. Inherent anisotropy in sand. Géotechnique, v.22, n.1, pp. 115-128, 1972.

AZEVEDO, M. A. A. Contribuição ao estudo geotécnico de solos de Viçosa - MG. Viçosa: UFV, 1999. 174 p. Dissertação (Mestrado em Engenharia Civil) Universidade Federal de Viçosa, 1999.

BALMACEDA, A.; JOSA, A.; GENS, A. and ALONSO, E.E. An elastoplastic model for partially saturated soils exhibiting a maximum collapse. Proc. $3^{\text {rd }}$ Int. Conf. On Comp. Plasticity, 1, Barcelona, 1992.

BARATA, F. E. "Landslides in the Tropical Region of Rio de Janeiro", Proc. $7^{\text {th }}$ ICSMFE, Mexico City, Mexico, vol 2, pp. 507 - 516, 1969.

BARATA, F. E.“Elucubrações sobre aspectos geotécnicos interessantes, específicos e diferençáveis dos solos tropicais, em geral, particularmente os do Brasil. In: Simpósio Brasileiro de Solos Tropicais em Eng., COPPE-UFRJ, 1981.

BATISTA, E. I. ; LIMA, D. C. and BUENO, B. S. Análise de risco para encostas de Viçosa. In: Simpósio Pan-Americano de Escorregamentos de Terra e Conferência Brasileira sobre Estabilidade de Encostas. 2, 1997, Rio de Janeiro. Anais... Rio de Janeiro: PSL/COBRAE, pp. 783-788, 1997.

BAVER, L. D.; GARDNER, W. H. and GARDNER, W.R. Soil physics. 4.ed. London, Wiley and Sons, Inc. 1972.

BERRE, T. and BJERRUM, L. "Shear Strenght of Normally Consolidated Clays",Proc. $8^{\text {th }}$ Int. Conf., International Conference on Soil Mechanics and Foudation Engineering, (ICSMFE), Moscow, U.S.S.R., Vol.1, pp. 39-49, 1973.

BISHOP, A. W. The principle of effective stress. Tecknisk Ukeblad, v. 106, n.39, p. 895-863, 1959.

BISHOP, A.W.; ALPAN, G. E.; BLIGHT, G. E. and DONALD, B. I. Factors controlling the shear strenght of partly saturated cohesive soils. In: Research Conference on Shear Strenght of Cohesive Soils, Bouder, 1960. Proceedings. American Society of Civil Engineers, pp. 503 - 532, 1960.

BLIGHT, G. E. Origin and formation of residual soils. In: "Mechanics of Residual Soils" (A guide to the formation, classification and geotechnical properties of residual soils, with advice for geotechnical design), Balkema / Rotterdam/ Brookfield, pp. 1-15, 1997. 
BLOCH, P. Stress state variables for unsaturated soils. Discussion by Peter Bloch. Journal of the Geotechnical Engineering Division . Proceedings of the American Society of Civil Engineers, New York, 104 (GT2): 303 - 306, 1978.

BOCKING, k. A. and FREDLUND. D. G. Limitation of the axis translation technique. In : International Conference on Expansive Soils, 4., Denver, pp. 117 - 135, 1980.

BRENNER, R.P.; GARCIA, V.K. and BLIGHT, G.E. Shear strength behaviour and the meassurement of shear strength in residual soils. In: Mechanics of Residual Soils. A guide to the formation, classification and geotechnical properties of residual soils, with advice for geotechnical design), Balkema/ Rotterdam/ Brookfield, pp. 155 220, 1997.

BRESSANI, L.A. and VAUGHAN, P.R. Damage to Soil Structure During Triaxial Testing. Proc. $12^{\text {th }}$. Int. Conf. Soil Mech. and Foundn. Engng. , Rio de Janeiro, 1989.

CARDOSO, D. L. Contribuição à identificação e tratamento dos solos expansivos da Região de Viçosa-MG. Viçosa, MG: UFV, 1994. 194p. Dissertação (Mestrado em Geotecnia) - Universidade Federal de Viçosa, 1994.

CARVALHO FILHO, A. Caracterização Mineralógica, química e física de solos de duas unidades de paisagem do planalto de Viçosa - MG. Viçosa, MG: UFV, 1989. 114p. Dissertação (Mestrado em Solos e Nutrição de Plantas) - Universidade Federal de Viçosa, 1989.

CASAGRANDE, A. and CARRILLO, N. “ Discussion on Study of Failure Envelope Soils ”, Journal of the Soil Mechanics and Foudations Division”, ASCE, Vol. 89, No.SM4, 1944.

COLEMAN, J. D. CORRESPONDENCE: stress/strain relations for partly saturated soil. Géotechnique, London, 12 (4), pp. 348 - 350, 1962.

CONLON, R. J. Landslide on the Toulnustoric river, Quebec, Can. Geotech. Jnl. 3, pp. 113-144, 1966.

CORRÊA, G. F. Modelo de evolução e mineralogia da fração argila do planalto de Viçosa- MG. Viçosa, MG: UFV, 1984. 87p. Dissertação (Mestrado em Solos e Nutrição de Plantas) - Universidade Federal de Viçosa, 1984.

COSTA FILHO, L. M.; DOBEREINER, L.; CAMPOS, T. M. P. and VARGAS JR., E.A. "Engineering Properties and Design Assessment of Tropical Soils: Fabric and Engineering Properties “, XII ICMFE, Rio de Janeiro, 1989.

COSTA FILHO, L. M. and CAMPOS, T. M. P. “Anisotropy of a Gneissic Residual Soil”, In: IX Panamerican Conf. On Soil Mech. And Found. Eng., Vina del Mar, Chile, Anais Vol.1, pp. 51-61, 1991. 
COZZOLINO, V. M. N. and NOGAMI, J. S. Classificação geotécnica MCT para solos tropicais. Solos e Rochas, São Paulo, v. 16, Nº 2, pp. 77-91, 1993.

CRUZ, P.T. "Solos Residuais - Algumas Hipóteses de Formulações Teóricas de Comportamento”. Seminário em Geotecnia de Solos Topicais ABMS-DF/UnB, Brasília, pp. 79 - 111, 1987.

DARAMOLA, O. Effect of Consolidation Age on Stiffness of Sand. Geotechnique, 30 (2), pp. $213-216,1980$.

DE CAMPOS, T. M. P. Testes de laboratório e testes de carregamento de placa instrumentados em um solo residual de gnaisse. Tese de mestrado, PUC-RJ, GAVEA, RJ, Brasil, 1980.

DEERE, D. U. and PATTON, F. D. "Slope Stability in Residual Soils". State of de Art Report, IV COPAMSEF, Porto Rico, vol 1, pp. 87-120, 1971.

DELAGE, P.; SURAJ DE SILVA, G. P. R. and DE LAURE, E. Un noveal appareil triaxial pour les sols non saturés. In: European Conference on Soil Mechanics and Foudation Engineering, 9., Dublin, 1987. Proceedings. Rotterdam, A. A. Balkema, pp. $25-28,1987$.

DE MELLO, V.F.B. “Apreciações sobre a Engenharia de Solos Aplicável a Solos Residuais”. III Conferência Sul Asiática de Engenharia de Solos, Hong Kong, 1972.

DESAI, M.D. Geotechnical aspects of residual soils of India. In Brand, E.W. \& Phillipson, H.B. (eds), Sampling and Testing of Residual Soils. Hong Kong: Scorpion Press, 1985.

DRUCKER, D. C.; ASCE, M.; GIBSON, E. and HENKEL, D. Soil mechanics and work-hardening theories of plasticity. Transactions, ASCE, v.122, pp. 338-346, 1957.

EDIL, T.B. and MOTAN, S. E. Laboratory evaluation of soil suction components. Geotechnical Testing Journal, ASTM, Philadelphia, 7(4): 173 - 181, 1984.

ESCARIO, V. Formulaciones para la definicion de la resistência a esfuerzo cortante de los suelos parcilmente saturados. Ingenieria Civil Nº 68, CEDEX, 1988.

ESCARIO, V. and JUCÁ, J. F. T. Strength and deformation of partly saturated soils. In: International Conference on Soil Mechanics and Foudation Engineering, 12., Rio de Janeiro, 1989. Proceedings. Rotterdam, A. A. Balkema,Vol.1, pp. 43 - 46, 1989. 
ESCARIO, V. and SAEZ, J. Shear strength of partly saturated soils versus suction. In: International Conference on Expansive Soils, New Delhi, Vol. 2, pp. 141 - 143, 1987.

FREDLUND. D. G. Apropriate concepts and techninology for unsaturated soils. Can. Geot. Jnl. 16, pp. $121-139,1979$.

FREDLUND, D. G.; ANQING, X. and SHANGYAN, H. Predicting the permeability function for unsatureted soils using the soil-water characteristic curve. Canadian Geotechnical Journal, v. 31, p. 533-546, 1994.

FREDLUND, D. G. and MORGENSTERN, N. R. Stress state variables for unsaturated soils. Journal of the Geotechnical Engineering Division. Proceedings of the American Society of Civil Engineers, New York, 103 (GT5): 447 - 466, 1977.

FREDLUND, D. G.; MORGENSTERN, N. R. and WIDGER, R. A. Shear strength of unsaturated soils. Geotechnique, v.15, n. 3, p. 313-321, 1978.

FREDLUND, D. G.; RAHARDJO, H. and GAN, J. K. M. Non linearity of strenght envelope for unsaturated soils. In: International Conference on Expansive Soils, 6, New Delhi, Vol. 2, pp. 49 - 54, 1987.

GAN, J. K. and FREDLUND, D. G. Shear strength behavior of two saprolitic soils. Proc. of two saprolitic soils. Proc. of First Int. Conf. On Unsaturated Soils. Paris, 1995.

GAN, J. K.; FREDLUND, D. G. and RAHARDJO, H. Determaination of the shear strenght parameters of an unsatureted soil using the direct shear test. Canadian Geotechnical Journal 25, pp. 500 - 510, 1988.

GENS, A. Constitutive modelling: application to compacted soils. In: PROCEEDINGS OF THE INTERNATIONAL CONFERENCE ON UNSATURETED SOILS UNSAT’95, 1, 1995, Paris. Proceedings... Paris: L' école Nationale Des Ponts et Chaussées, Vol. 1, pp. 1179-1200, 1995.

GEOLOGICAL SOCIETY ENGINEERING GROUP WORKING PARTY REPORTS

- The Quartely Journal of Engineering Geology, Geological Society Engineering Group Working Party Report: Tropical Soils, vol. 23, N 1, 1990.

GRAHAM, J.; NOONAM, M. L. and LEW, K. V. Yield states and stress/strain behaviour of natural soft clays. Géotechinic, 33 (3), 1983.

GREEN, G. E. Strength and deformation of sand meassured in an independent stress control cell. In: ROSCOE MEMORIAL SYMPOSIUM, 1971, Cambrige. Proceedings... Cambrige: Cambrige University, pp. 285-323, 1971. 
GREEN, G. E. , READES, D.W. Boundary conditions, anisotropy and sample shape effects on the stress-strain behaviour of sand in triaxial compression and plane strain. Geotechnique, Vol. 25, N. 2, pp. $333-356,1975$.

GUIMARÃES, L. S. P. Caracterização química e geotécnica de um perfil de solo residual. Viçosa, MG: UFV, 1996. 96p. Dissertação (Mestrado em Geotecnia) Universidade Federal de Viçosa, 1996.

GULHATI, S. K. \& SATIJA, B. S. Shear strength of partially saturated soils. In: International Conference on Soil Mechanics and Foudation Engineering. 10., Stockholm, 1981, Proceedings, pp. 609 - 621, 1981.

HILLEL. D. Soil water - Physical principles and processes. New York, Academic Press, 1971.

HILF, J. W. An investigation of pore water pressure in compacted soils. Bureau of reclamation tech. mem, 1956.

HO, D. Y. F. and FREDLUND, D.G. A multistage triaxial test for unsaturated soils. Geotechnical Testing Journal, ASTM, Philadelphia, 5 (1/2): 18 - 25, March / June 1982.

IAEG. "Rock and Soil Description and Classification for Engineering Geological Mapping”. IAEG Comission on Engineering Geological Mapping Report, Bull. Int. Assoc. Engng. Geol. 24, pp. 235 - 274, 1981.

ISRM. "Basic Geotechnical Description for Rock masses". ISRM Comission on Classification of Rock and Rock Masses. Int. J. Rock Mech. Min. Sci. \& Geomech. Abstr. 18, pp. 85-110, 1981.

JOSA, A.; ALONSO, E. E.; LLORET, A. and GENS, A. Stress-strain behaviour of partially satureted soils. In: EUROPEAN CONFERENCE ON SOIL MECHANIC AND FOUDATION. ENGINEERING, 9, 1987, Dublin. Proceedings... Dunblin: Vol. 2, pp. 561-564, 1987.

KER, J. C, SCHAEFER, C.E.R. Roteiro de excursão do XXV Congresso Brasileiro de Ciência do Solo: Viçosa-Sete Lagoas. Viçosa: Departamento de Solos, Universidade Federal de Viçosa, 1995. 47p.

KIERSH, G.A. and TREASHER, R.C. "Investigations, Areal and Engineering Geology - Folsom Dam Project, Central California”. Econ. Geology, Vol. 50, Nº. 3, pp. 271 -310, 1955. 
KNILL, J. L. and JONES, K.S. "The Recording and Interpretation of Geological Conditions in the Foundation of the Roseires, Kariba and Latiyan Dams”. Geotechnique, Vol. 15, Nº 1, pp. 94-124, 1965.

LADE, P.V and KIM, M. K. Single hardening constitutive model for frictional materials. II. Yeld criterion and plastic work contours. Computers and Geotechnics 6, Elsevier Science Publishers Ltd., pp.13-29, 1988.

LEROUEIL, S. and VAUGHAN, P.R. "The General and Congruent Effects of Structure in Natural Soils and Weak Rocks”. Géotechinique, Vol. 40, Nº. 3, pp. 467-488, 1990.

LITTLE, A. L. “Laterites”. $3^{\text {rd }}$ Asian Regional Conference on Soil Mechanics and Foudation Enginneering, Haifa, Israel, vol. II, pp. 61 - 71, 1967.

LITTLE, A. L. “Discussion on Engineering Grade Zones”. Proc. Conference on In Situ Investigations in Soils and Rocks, Britsh Geotech. Soc., London, pp. 57-58, 1970.

LUÍS, P. D. G. Caracterização Geotécnica e Considerações sobre a Estabilidade de Taludes em Solos Residuais de Viçosa - MG. Viçosa, MG: UFV, 2000. 135p. Dissertação (Mestrado em Geotecnia) - Universidade Federal de Viçosa, 2000.

MACCARINI, M. "Ensaios Triaxiais e de Cisalhamento Direto no Solo Residual Gnáissico Jovem do Campo Experimental da PUC-Rio, Gávea”, Dissertação de Mestrado, PUC-Rio, Rio de Janeiro, 1980.

MACCARINI, M. Laboratory Studies of a Weakly Bonded Artificial Soil. Ph. D. Thesis, Imperial College of Science and Technology, London, 1987.

MACCARINI, M. "Estudo da Quebra de Cimentações de um Solo Artificial. Uma Tentativa de Modelo para Solos Residuais”, II Colóquio de Solos Tropicais e Subtropicais e suas Aplicações em Engenharia Civil, Porto Alegre, pp. 82-95, 1989.

MACCARINI, M.; TEIXEIRA, V.H. and TRICHES, G. Bonding Properties of a Residual Soil Derived from Diabase. XII ICSMFE, Rio de Janeiro, 1989.

MACHADO, S. L. "Aplicações de Conceitos de Elastoplasticidade a Solos Não Saturados”, Dissertação de Doutorado, USP, São Paulo, 1998.

MACIEL, I. C. Q. "Aspectos Microestruturais e Propriedades Geomecânicas de um Perfil de Solo Residual de Gnáisse Facoidal”, Dissertação de Mestrado, PUC-Rio, Rio de Janeiro, 1991. 
MARSHALL, T. J. and HOLMES, J. W. Soil Physics. Cambridge, Cambridge University Press, 1981.

MATYAS, E. L. and RADHAKRISHNA. Volume change characteristics of partially saturated soils. Géotechnique, London, 18 ( 4 ), pp. 432 - 448, 1968.

MITCHELL, J. K. Fundamentals of Soil Behavior. New York, John Wiley and Sons, 1976.

MITCHELL, J.K. and SOLYMAR, Z.V. Time Dependent Strenght Gain in Freshly Deposited or Densified Sand. JL. of Geotech. Eng., vol. 110, N. ${ }^{0}$ 11, 1984.

MIURA, K. Study on the deformation behaviour of anisotropic sand under principal stress axes rotation. Hokkaido: Hokkaido University, 223p, 1985. (Ph. D. Thesis)

MOREIRA, A.A.N. Relevo. In: Instituto Brasileiro de Geografia. Geografia do Brasil: grande região leste. Rio de Janeiro, pp. 7 - 54, 1965.

MORI, R.T.; LEME, C.R.M.; ABREU, F.L.R and PAN, Y.F. "Saprolitos de Basalto Um Estudo de seu Comportamento Geotécnico em Maciços Compactados”. VI COBRAMSEF, Rio de Janeiro, RJ, pp. 207-228, 1978.

MOYE, D. G. "Engineering Geology for the Snowy Mountains Scheme”. Journal of the Institution of Engineers Australia, 27, pp. 281-299, 1955.

MURPHY, C. P. Thin section preparation of soils and sediments. [S.I], AB Academic, 149p, 1986.

NAKASE, A. and KAMEI, T. Influence of strain rate on undrained shear characteristics of ko consolidated cohesive soils”, Soils and Foundations, Vol. 26, $\mathrm{N}^{\mathrm{o}}$.1, pp. 85-95, 1986.

NEGUSSEY, D. An experimental study of the small strain response of sand. Canada: University of British Columbia / Department of Civil Engineering, 1984. (Ph.D. Thesis)

NEWILL, D. A laboratory investigation of two red clays from Kenya. Geotechnique, 11, $302-318,1961$.

NOGAMI, J.S. “Os Solos Residuais do Estado de São Paulo - Sua Caracterização em Bases Geológicas para Fins Rodoviários”, Tese de Doutorado, EPUSP, São Paulo, 89 p, 1967. 
NOGAMI, J. S. and VILLIBOR, D. F. Uma nova classificação de solos para finalidades rodoviárias. In: Simpósio Brasileiro de Solos Tropicais em Engenharia, 1981, Rio de Janeiro. Anais... Rio de Janeiro: COPPE/UFRJ/CNPq/ABMS, pp. 30 - 41, 1981.

NOVAIS FERREIRA, H. "Characterization, Identification and Classification of Tropical Lateritic and Saprolitic Soils for Geotechnical Purposes”. 1 st Int. Conf. on Tropical Soils, Brasil, pp. 139 - 170, 1985.

NUNES, W. A. G. A.; SCHAEFER, C. E. R.; KER, J. C. e FERNANDES-FILHO, E. I. Caracterização micropedológica de alguns solos da Zona da Mata Mineira. Revista Brasileira de Ciência do Solo, 2000, 24: 103-116.

ODA, M. Initial fabrics and their relations to mechanical properties of granular material.

Soils and Foudations, Japanese Society of Soil Mechanics and Foudation Engineering, Vol. 12, Nº.1, pp. 17-36, 1972.

ODA, M. Anisotropic strenght of cohesionless sands. Journal of Geotechnical Engineering, ASCE, Vol. 107, GT9, pp.1219-1231, 1981.

ODA, M.; KOISHIKAWA. I.; HIGUCHI, T. “ Experimental study of anisotropic shear strenght of sand by plane strain test”, Soils and Foudations, Japanese Society of Soil Mechanics and Foudation Engineering, Vol. 18, Nº 1, pp. 25 - 38, 1978.

PASTORE, E. L. Maciços de solos saprolíticos como fundação de barragens de concreto gravidade. Tese de doutorado, EESC, São Carlos, 1992.

PINGS, W.B. "Bacterial Leaching”, Mineral Undustries Bulletin, Colorado School of Mines, Vol. 2, Nº. 3, pp.19, 1968.

PINTO, C. S. Curso Básico de Mecânica dos Solos (Segunda edição - com exercícios resolvidos, em 16 aulas). São Paulo: Oficina de Textos, 2002.

PINTO, C.S.; GOBARA, W.; PERES, J.E.E. \& NADER, J.J. "Propriedades dos Solos Residuais”. Solos do Interior de São Paulo, ABMS-NRSP, Depto. Geotecnia da EESC-USP, pp. 95-142, 1993.

PINTO, O. C. B. Formation of Kaolinite from a biotite-feldspar gneiss in four strongly weathered soil profiles from Minas Gerais, Brazil. West Lafayette, EUA: Purdue University (Dissertação de Mestrado), 133p, 1971

QUARESMA, H. D. Ensaios triaxiais cúbicos em areia saturada. Rio de Janeiro, RJ: PUC, 1997. 92p. Dissertação (Mestrado em Geotecnia) - Pontifícia Universidade Católica do Rio de Janeiro, 1997. 
RAMALHO, G. G. C. Mapeamento Geotécnico de Viçosa com uso de sistema de informações geográficas. Viçosa, UFV, 1994, 110p. Dissertação (Mestrado em Geotecnia) - Universidade Federal de Viçosa, 1994.

REIS, R. M. Desenvolvimento e Utilização de um Equipamento Triaxial Cúbico no Estudo da Anisotropia de um Solo Residual de Gnaisse da Região de Viçosa (Minas Gerais), Dissertação de Mestrado, UFV, 1998.

REIS, R.M. e AZEVEDO, R.F. Características de Deformabilidade e Resistência de um Solo Residual de Gnaisse da Região Metropolitana da Cidade de Viçosa, Anais do XI Congresso Brasileiro de Mecânica dos Solos e Engenharia Geotécnica, Brasília, Brasil, Vol. 1., pp.213-220, 1998.

REIS, R. M. and AZEVEDO, R. F. Anisotropy Study of Residual Soil Based on Cubical Triaxial Test Results. Pan American Conference, Foz do Iguaçu, Brasil, 1999.

REZENDE, S. B. Estudo de crono-topossequência em Viçosa-Minas Gerais. Viçosa, MG: UFV, 1971, 71p. Dissertação (Mestrado em Fitotecnia) - Universidade Federal de Viçosa, 1971.

RICHARDS, B. G.; EMERSOM, W. W. and PETER, P. Discution of "Evaluation of soil suction components ” by T. B. Edil and S. E. Motan. Geothecnical Testing Journal, ASTM, Philadelphia, 9 (1) : 41 - 45 , March, 1986.

RÖHM, S. A. Resistência ao Cisalhamento de um solo arenoso laterizado não saturado da região de São Carlos - S. P. Tese de Doutorado, EESC/USP, São carlos, 1992.

ROHM, S. A. e VILAR, O. M. A influência da estrutura de um solo arenoso laterizado não saturado na sua resistência ao cisalhamento. In: SIMPÓSIO SOBRE SOLOS NÃO SATURADOS, 2, Recife. Anais... Recife: UFPE, 1994. pp. 211-216, 1994.

ROHM, S. A. e VILAR, O. M. Shear strength of an unsaturated sandy soil. In: PROCEEDINGS OF THE INTERNATIONAL CONFERENCE ON UNSATURETED SOILS - UNSAT’95, 1, 1995, Paris. Proceedings... Paris: L' école Nationale Des Ponts et Chaussées, Vol. 1, pp. 189 - 193, 1995.

ROSCOE, K. H. and BURLAND, J. B. On the generalised stress/strain behaviour of "wet clay", in J. Heyman and F. A. Leckie (eds,) Engineering plasticity (Cambridge: Cambridge University Press), 1968. Apud WOOD, D. M. Soil behavior and critical state soil mechanics. Cambridge University Press, 1990.

ROSCOE, K. H.; SCHOFIELD, A. N. and THURAIRAJAH, A. Yielding of Clays in states wetter than critical. Géotechnique, 13 (3), 1963. 
ROSCOE, K. H.; SCHOFIELD, A. N. and WROTH, M. A. On the yielding of Soils. Géothechnique, 8 (1), 1958.

RUXTON, B. P. and BERRY, L. "Weathering of Granite and associated Erosional Features in Hong Kong”, Bull. Geol. Soc. Amer., Vol. 68, pp. 1263 - 1292, 1957.

SANDRONI, S. S. Stress Relief Effects in Gneissic Saprolitic Soils. 1st. Int. Conf. Geomechanics in Tropical Soils, vol. 3, Brasilia, 1985.

SANDRONI, S. S. e MACCARINI, M. Ensaios Triaxiais e de Cisalhamento Direto em uma Ocorrência de Solo Residual Gnaissico Jovem Rico em Fedspato. Simpósio Brasileiro de Solos Tropicais em Eng. Vol. 1, COPPE-UFRJ, 1981.

SANGREY, D. A. Naturally cemented sensitive soils. Geotechnique, Vol 22, N . 1, pp 139-152, 1972.

SARDINHA, A.E.; SCHWAB, P.R. and KOMESU, I. "Utilização de Saprolitos de Basalto em Aterros Compactados na Usina Hidrelétrica Salto Santiago - Eletrosul”. III CBGE, Itapema, SC, Vol. 1, pp. 93-120, 1981.

SAUNDERS, M.K. and FOOKES, P.G. "A review of the relationship of rock weathering and climate and its significance to foundation engineering”, Eng. Geol. 4, Amsterdam, Vol. 4, pp. 289-325, 1970.

SAYÃO, A.S. F.J. Behaviour of sand under general stress paths in the hollow cylinder torsional device. University of British Columbia, 1989. (Ph. D. Thesis).

SCHAEFER, C. E. R. The microstructure of Brazilian latosols as long-term biotic contructs. In: Congresso Latino-Americano de Ciência do Solo, 13, 1996, Piracicaba. Anais...Piracicaba: pp. 1- 20, 1996.

SCHAEFER, C. E. R. ; ALBUQUERQUE FILHO, M. R. and GALVÃO, J. C. C. Micropedological effects of compost and fertilizer incorporation in a clayey Ultisol, cultivated with maize, from Coimbra, MG. Congresso Latino Americano de Ciência do Solo, 13, 1966, Piracicaba. Anais...Piracicaba, 1996.

SCHOFIELD, A. N. and WROTH, C. P. Critical states soil mechanics .McGraw-hill, London, 1968. Apud KO, H. and STURE, S. State of the art: Data reduction and aplications for analytical modeling. ASTM STP 740, 1981.

SHANKARIAH, B. and RAMAMURTHY, T. Strenght and development behaviour of sand under general stress system. In: AUSTRALIA - NEW ZEALAND CONF. ON GEOMECHANICS, 3. Proceedings ... Vol.1, pp. 1 - 212, 1980. 
SOWERS, G. F. "Soil Problems in the Southern Piedmont Region”. ASCE, vol. 80, Separate 416, 18 p, 1953.

SOWERS, G. F. "Engineering Properties of Residual Soils derived from Igneous and Metamorphic Rocks". $2^{\text {nd }}$ Pan-American Conf. Soil Mech. Found. Eng., Brasil, Vol. 1, pp. $39-61,1963$.

SOWERS, G.F. Discussion, $3^{\text {rd }}$ Panamerican Congress on Soil Mechanics and Foudation Engineering, Caracas, Vol. III, pp. 135 - 143, 1967.

STANCATI, G. Estudo Experimental do Comportamento Tensão x Deformação de uma Argila Adensada Unidirecionalmente. Tese de Doutorado. São Carlos, Escola de Engenharia de São Carlos, Universidade de São Paulo, 244p, 1991.

SYMES, M.J. Rotation of principal stresses in sand. London : University of London/Dept. of Civil Engineering, 548p, 1983. (Ph.D. Thesis)

TATSUOKA, F.; SAKAMOTO, M. and KAWAMURA, T. Strength and deformation characteristics of sand in plane strain compression at extremely low pressures. Soils and Foudations, Japanese Society of Soil Mechanics and Foundation Engineering, Vol. 26, $\mathrm{N}^{\mathrm{o}}$. 1, pp. $65-84,1986$.

TAVENAS, F.; DES ROSIERS, J.P.; LEROUEIL, S.; LAROCHELLE, P. and ROY, M. "The use of strain energy as a yield and creep criterion for lightly overconsolidated clays”. Geotechinique 29 (3), pp. 285-303, 1979.

TEIXEIRA, R. S. Resistência ao cisalhamento de um solo arenoso compactado não saturado. Dissetação de mestrado. EESC/USP, São Carlos, 1996.

TEIXEIRA, R. S e VILAR, O. M. Resistência ao cisalhamento de um solo compactado não saturado. In: SIMPÓSIO BRASILEIRO DE SOLOS NÃO SATURADOS - ̃̃ SAT’ 97, 3, 1997, Rio de Janeiro. Anais... Rio de Janeiro: Freitas Bastos, Vol. 1, pp. 161-169, 1997.

TOWNSEND, D. L.; SANGREY, D. A. and WALKER, L. K. The britlle behaviour of naturally cemented soils. $7^{\text {th }}$ ICSMFE, Mexico City 2, pp. 411-417, 1969.

VARGAS, M. Engineering properties of residual soils from South Central region of Brazil. In: ICIACEG, 2, IAEG, Vol. IV, pp. 5.1 - 5.26, São Paulo, 1974.

VARGAS, M. Some engineering properties of residual clay soils occurring in southern Brazil. Proceedings of the 3rd International Conference Soil Mechanics and Foudation Engineering, Zurich. 1, pp. 67 - 71, 1953. 
VARGAS, M. "Residual Soil Sampling”. Proc. Specialty Session $\mathrm{N}^{0} 1$ on Soil Sampling, $7^{\text {th }}$ International Conference on Soil Mechanics an Foundation Engineering, Melbourne, Australia, pp. 50 - 53, 1969.

VARGAS, M. “Geotecnia dos Solos Residuais”, Revista Latino Americana de Geotecnia, Vol. 1, pp.20 - 41, 1971.

VARGAS, M. Structurally unstable soils in Southern Brazil. Proceedings of the $8^{\text {th }}$ International Conference on Soil Mechanics and Foudation Engineering, Moscow, 2, 239-246, 1973.

VARGAS, M. The concept of tropical soils. In: Intl. Conf. on Geomech. In Tropical Lateritc and Saprolitic Soils, 1, ISSMFE, Vol. 3, pp. 101-134, Brasília, 1985.

VARGAS, M.; SILVA, F.P. and TUBIO, M. "Residual Clay Dams in the State of São Paulo, Brazil”. $6^{\text {th }}$ International Conference on Soil Mechanics and Foudation Engineering, Montreal, Vol. II, pp. 578 - 582, 1965.

VAUGHAN, P.R. "Mechanical and hydraulic properties of tropical lateritic and saprolitc soils, particulary as related to their structure and mineral components. First International Conference in Tropical Lateritic and Saprolitic Soils, Brasilia, 1985.

VAUGHAN, P.R. Characterising the Mechanical Properties of in-situ Residual Soils. $2^{\text {nd }}$. International Conference on geomechanics in Tropical Soils, Singapore, pp. 20 $-37,1988$.

VAUGHAN, P. R. and KWAN, C.W. Weathering, Structure and in situ Stress in Residual Soils. Géotechinique 34, Nº 1, pp. 43-59, 1984.

VAUGHAN, P. R.; MACCARINI, M. and MOKHTAR, S.M. "Indexing the Engineering Properties of Residual Soil”, Quaterly Journal of Engineering Geology, London, Vol. 21, pp. 69-84, 1988.

VAZ, L. F. Estudo Geológico de barragens. In: SPGA, 1, São Paulo, 1969.

VAZ, L. F. Classificação Genética dos Solos e dos Horizontes de Alteração de Rocha em Regiões Tropicais. Solos e Rochas, São Paulo, 19 (2), pp. 117 - 136, 1996.

VILAR, O. M. Proposta sujerida pessoalmente, 2003.

VILAR, O.M; BORTOLUCI, A.A. and RODRIGUES, J.E. Geotechnical Characteristics of tropical cenozoic sediment from São Carlos region, Brasil. First International Conference in Tropical Lateritic na Saprolitic Soils, Brasil, Vol 2, pp. $461-470,1985$. 
WALLACE, K.B. Structural behaviour of residual soils of the continually wet Highlands of Papua New Guinea. Geotechnique, 23, No. 2, 203-218, 1973.

WEBB, P. A. and ORR, C. Analytical Methods in Fine Particle Technology, Micromeritics Instrument, Norcross, GA, USA, 1997.

WESLEY, L. D. Influence of Structure and Composition on Residuals Soils. Journal of Geotech. Eng., vol. 116, N. ${ }^{\circ}$ 4, pp. 589-603, 1990.

WOLLE, C. M. et al. Pecularities of "in situ”behavior of tropical soils: slope stability. Committee on tropical soils: slope stability. Committee on tropical soils. In: Intl. Conf. on Geomech. In Tropical Lateritic and Saprolitic Soils, 1, ISSMFE, Brasília, 1985.

WOLLE, C. M. and HACHICHI, W. Rain - induced landslides in southeastern Brazil. In: International Conference on Soil Mechanics and Foundation Engineering, 12., Rio de Janeiro, 1989. Proceedings. Rotterdam, A. A. Balkema, Vol. 3, pp. 16391642, 1989.

WOOD, D. M. Soil Behavior and Critical State Soil Mechanics - Cambridge University Press, 1992.

WOOD, D. M. The behaviour of partly saturated soils: a review . Cambridge University Engineering Departament Technical Report. CUED/D - Soils/TR69. 71p, 1979.

YAMADA, Y. and ISHIHARA, K. Anisotropic deformation characteristics of sand under three dimensional stress conditions. Soils and Foundations, Japanese Society of Soil Mechanics and Foundation Engineering, Vol. 19, N. 2, pp. 79-94, 1979.

YAMADA, Y. and ISHIHARA, K. Undrained deformation characteristics of loose sand under three dimensional stress conditions. Soil and Foundations, Japanese Society of Soil Mechanics and Foudation Engineering, Vol. 21, N. 1, pp. 97 - 107, 1981. 


\section{NORMAS TÉCNICAS}

MB-28 (NBR6508/ABNT-1984) - Grãos de solo que passam na peneira 4 Determinação da massa específica.

MB-30 (NBR6459/ABNT-1984) - Solo - Determinação do limite de liquidez.

MB-31 (NBR7180/ABNT-1984) - Solo - Determinação do limite de plasticidade.

MB-32 (NBR 7181/ABNT-1984) - Solo - Análise granulométrica. 
9 ANEXOS

DIMENSÕES E CARACTERÍSTICAS DOS CORPOS DE PROVA DOS DOIS HORIZONTES, JOVEM E MADURO, DO SOLO RESIDUAL DE GNAISSE UTILIZADO PARA A REALIZAÇÃO DOS ENSAIOS TRIAXIAIS 
ANEXO 1 - Dimensões, índices físicos e parâmetro B dos corpos de prova do solo residual jovem, submetidos aos ensaios de compressão triaxial convencionais drenados, saturados e em diferentes direções de carregamento.

\begin{tabular}{|c|c|c|c|c|c|c|c|c|c|c|c|c|c|}
\hline $\begin{array}{c}\text { direção de } \\
\text { carregamento }\end{array}$ & $\begin{array}{c}\sigma_{\mathrm{c}} \\
(\mathrm{kPa})\end{array}$ & $\begin{array}{c}\mathrm{H} \\
(\mathrm{cm})\end{array}$ & $\begin{array}{c}\mathrm{D} \\
(\mathrm{cm})\end{array}$ & $\begin{array}{c}\mathrm{V} \\
\left(\mathrm{cm}^{3}\right)\end{array}$ & $\begin{array}{c}\text { Peso } \\
(\mathrm{N})\end{array}$ & $\begin{array}{c}\mathrm{w} \\
(\%)\end{array}$ & $\begin{array}{c}\gamma \\
\left(\mathrm{KN} / \mathrm{m}^{3}\right)\end{array}$ & $\begin{array}{c}\gamma_{\mathrm{s}} \\
\left(\mathrm{KN} / \mathrm{m}^{3}\right)\end{array}$ & $\begin{array}{c}\gamma_{\mathrm{d}} \\
\left(\mathrm{KN} / \mathrm{m}^{3}\right)\end{array}$ & $\begin{array}{c}\mathrm{e}_{0} \\
(\%)\end{array}$ & $\begin{array}{c}\mathrm{Sr} \\
(\%)\end{array}$ & $\mathrm{B}$ \\
\hline vertical & 50 & 10,00 & 4,97 & 194,00 & 3,58 & 17,53 & 18,45 & 26,70 & 15,70 & 0,70 & 41 & 67 & 0,98 \\
\hline vertical & 100 & 9,88 & 4,93 & 188,60 & 3,43 & 17,67 & 18,19 & 26,70 & 15,46 & 0,73 & 42 & 65 & 0,98 \\
\hline vertical & 150 & 9,90 & 5,04 & 197,51 & 3,51 & 17,86 & 17,77 & 26,70 & 15,08 & 0,77 & 44 & 62 & 0,98 \\
\hline vertical & 200 & 9,95 & 4,93 & 189,94 & 3,45 & 18,67 & 18,16 & 26,70 & 15,31 & 0,74 & 43 & 67 & 0,98 \\
\hline vertical & 400 & 9,97 & 4,99 & 194,98 & 3,44 & 18,08 & 17,64 & 26,70 & 14,94 & 0,79 & 44 & 61 & 0,98 \\
\hline & & & & & & & & & & & & & \\
\hline ortogonal & 50 & 9,60 & 5,00 & 188,50 & 3,42 & 17,51 & 18,14 & 26,70 & 15,44 & 0,73 & 42 & 64 & 0,98 \\
\hline ortogonal & 100 & 9,93 & 4,92 & 188,79 & 3,46 & 17,41 & 18,33 & 26,70 & 15,61 & 0,71 & 42 & 65 & 0,98 \\
\hline ortogonal & 150 & 9,47 & 5,00 & 185,94 & 3,33 & 17,51 & 17,91 & 26,70 & 15,24 & 0,75 & 43 & 62 & 0,98 \\
\hline ortogonal & 250 & 9,33 & 5,00 & 183,19 & 3,28 & 17,67 & 17,90 & 26,70 & 15,22 & 0,75 & 43 & 63 & 0,98 \\
\hline ortogonal & 400 & 9,45 & 5,00 & 185,55 & 3,43 & 18,00 & 18,49 & 26,70 & 15,67 & 0,70 & 41 & 68 & 0,98 \\
\hline & & & & & & & & & & & & & \\
\hline paralela & 50 & 9,93 & 5,00 & 194,98 & 3,55 & 17,38 & 18,21 & 26,70 & 15,51 & 0,72 & 42 & 64 & 0,98 \\
\hline paralela & 100 & 9,72 & 4,97 & 188,57 & 3,36 & 17,72 & 17,82 & 26,70 & 15,14 & 0,76 & 43 & 62 & 0,98 \\
\hline paralela & 150 & 9,34 & 5,00 & 183,39 & 3,46 & 17,83 & 18,87 & 26,70 & 16,01 & 0,67 & 40 & 71 & 0,98 \\
\hline paralela & 250 & 9,68 & 4,90 & 182,54 & 3,34 & 17,92 & 18,30 & 26,70 & 15,52 & 0,72 & 42 & 66 & 0,98 \\
\hline paralela & 400 & 9,90 & 4,96 & 191,29 & 3,48 & 17,26 & 18,19 & 26,70 & 15,51 & 0,72 & 42 & 64 & 0,98 \\
\hline
\end{tabular}

ANEXO 2 - Dimensões, índices físicos e parâmetro B dos corpos de prova do solo residual maduro, submetidos aso ensaios de compressão triaxial convencionais drenados, saturados e em diferentes direções de carregamento.

\begin{tabular}{|c|c|c|c|c|c|c|c|c|c|c|c|c|c|}
\hline $\begin{array}{c}\text { direção de } \\
\text { carregamento }\end{array}$ & $\begin{array}{c}\sigma_{\mathrm{c}} \\
(\mathrm{kPa})\end{array}$ & $\begin{array}{c}\mathrm{H} \\
(\mathrm{cm})\end{array}$ & $\begin{array}{c}\mathrm{D} \\
(\mathrm{cm})\end{array}$ & $\begin{array}{c}\mathrm{V} \\
\left(\mathrm{cm}^{3}\right)\end{array}$ & $\begin{array}{c}\text { Peso } \\
(\mathrm{N})\end{array}$ & $\begin{array}{c}\mathrm{w} \\
(\%)\end{array}$ & $\begin{array}{c}\gamma \\
\left(\mathrm{KN} / \mathrm{m}^{3}\right)\end{array}$ & $\begin{array}{c}\gamma_{\mathrm{s}} \\
\left(\mathrm{KN} / \mathrm{m}^{3}\right)\end{array}$ & $\begin{array}{c}\gamma_{\mathrm{d}} \\
\left(\mathrm{KN} / \mathrm{m}^{3}\right)\end{array}$ & $\mathrm{e}_{0}$ & $\begin{array}{c}\mathrm{n} \\
(\%)\end{array}$ & $\begin{array}{c}\mathrm{Sr} \\
(\%)\end{array}$ & $\mathrm{B}$ \\
\hline vertical & 50 & 9,97 & 4,94 & 191,09 & 3,17 & 26,09 & 16,59 & 27,20 & 13,16 & 1,07 & 52 & 66 & 0,98 \\
\hline vertical & 100 & 9,73 & 4,94 & 186,49 & 3,21 & 27,30 & 17,21 & 27,20 & 13,52 & 1,01 & 50 & 73 & 0,98 \\
\hline vertical & 150 & 9,63 & 4,98 & 187,57 & 3,09 & 26,56 & 16,47 & 27,20 & 13,02 & 1,09 & 52 & 66 & 0,98 \\
\hline vertical & 200 & 9,25 & 4,82 & 168,78 & 2,82 & 26,52 & 16,71 & 27,20 & 13,21 & 1,06 & 51 & 68 & 0,98 \\
\hline vertical & 250 & 9,96 & 4,96 & 192,45 & 3,37 & 26,77 & 17,51 & 27,20 & 13,81 & 0,97 & 49 & 75 & 0,98 \\
\hline & & & & & & & & & & & & & \\
\hline horizontal & 100 & 9,94 & 4,93 & 189,74 & 3,20 & 28,63 & 16,88 & 27,20 & 13,12 & 1,07 & 52 & 73 & 0,98 \\
\hline horizontal & 200 & 9,67 & 4,94 & 185,34 & 3,07 & 28,59 & 16,58 & 27,20 & 12,89 & 1,11 & 53 & 70 & 0,98 \\
\hline horizontal & 250 & 9,95 & 4,93 & 189,94 & 3,11 & 28,20 & 16,36 & 27,20 & 12,76 & 1,13 & 53 & 68 & 0,98 \\
\hline & & & & & & & & & & & & & \\
\hline $45^{\circ}$ & 50 & 9,91 & 4,94 & 189,94 & 3,21 & 28,70 & 16,90 & 27,20 & 13,13 & 1,07 & 52 & 73 & 0,98 \\
\hline $45^{\circ}$ & 150 & 9,88 & 4,90 & 186,31 & 3,08 & 28,65 & 16,53 & 27,20 & 12,85 & 1,12 & 53 & 70 & 0,98 \\
\hline $45^{\circ}$ & 200 & 9,93 & 4,95 & 191,10 & 3,37 & 26,77 & 17,64 & 27,20 & 13,91 & 0,96 & 49 & 76 & 0,98 \\
\hline
\end{tabular}


ANEXO 3 - Dimensões, índices físicos e parâmetro B dos corpos de prova do solo residual jovem e maduro, submetidos aso ensaios triaxiais de compressão hidrostática, saturados e em diferentes direções de carregamento.

\begin{tabular}{|c|c|c|c|c|c|c|c|c|c|c|c|c|c|}
\hline solo & $\begin{array}{c}\text { direção de } \\
\text { carregamento }\end{array}$ & $\begin{array}{c}\mathrm{H} \\
(\mathrm{cm})\end{array}$ & $\begin{array}{c}\mathrm{D} \\
(\mathrm{cm})\end{array}$ & $\begin{array}{c}\mathrm{V} \\
\left(\mathrm{cm}^{3}\right)\end{array}$ & $\begin{array}{c}\text { Peso } \\
(\mathrm{N})\end{array}$ & $\begin{array}{c}\mathrm{w} \\
(\%)\end{array}$ & $\begin{array}{c}\gamma \\
\left(\mathrm{KN} / \mathrm{m}^{3}\right)\end{array}$ & $\begin{array}{c}\gamma_{\mathrm{s}} \\
\left(\mathrm{KN} / \mathrm{m}^{3}\right)\end{array}$ & $\begin{array}{c}\gamma_{\mathrm{d}} \\
\left(\mathrm{KN} / \mathrm{m}^{3}\right)\end{array}$ & $\mathrm{e}_{0}$ & $\begin{array}{c}\mathrm{n} \\
(\%)\end{array}$ & $\begin{array}{c}\mathrm{Sr} \\
(\%)\end{array}$ & $\mathrm{B}$ \\
\hline jovem & vertical & 9,96 & 5,00 & 195,56 & 3,62 & 19,27 & 18,51 & 26,70 & 15,52 & 0,72 & 42 & 71 & 0,98 \\
\hline jovem & ortogonal & 9,93 & 4,95 & 191,10 & 3,46 & 17,53 & 18,11 & 26,70 & 15,41 & 0,73 & 42 & 64 & 0,98 \\
\hline jovem & paralela & 9,89 & 4,94 & 189,56 & 3,31 & 16,45 & 17,46 & 26,70 & 15,00 & 0,78 & 44 & 56 & 0,98 \\
\hline maduro & vertical & 9,90 & 4,94 & 189,75 & 3,21 & 28,00 & 16,92 & 27,20 & 13,22 & 1,06 & 51 & 72 & 0,98 \\
\hline maduro & horizontal & 9,89 & 4,93 & 188,79 & 3,16 & 27,63 & 16,75 & 27,20 & 13,12 & 1,07 & 52 & 70 & 0,98 \\
\hline
\end{tabular}

ANEXO 4 - Dimensões, índices físicos e parâmetro B dos corpos de prova do solo residual jovem, submetidos aos ensaios de tensão controlada em trajetórias diferentes da convencional, saturados e na direção vertical.

\begin{tabular}{|c|c|c|c|c|c|c|c|c|c|c|c|c|c|}
\hline $\begin{array}{c}\text { Trajetória } \\
(\mathrm{p}, \mathrm{q})\end{array}$ & $\begin{array}{c}\sigma_{\mathrm{c}} \\
(\mathrm{kPa})\end{array}$ & $\begin{array}{c}\mathrm{H} \\
(\mathrm{cm})\end{array}$ & $\begin{array}{c}\mathrm{D} \\
(\mathrm{cm})\end{array}$ & $\begin{array}{c}\mathrm{V} \\
\left(\mathrm{cm}^{3}\right)\end{array}$ & $\begin{array}{c}\text { Peso } \\
(\mathrm{N})\end{array}$ & $\begin{array}{c}\mathrm{w} \\
(\%)\end{array}$ & $\begin{array}{c}\gamma \\
\left(\mathrm{KN} / \mathrm{m}^{3}\right)\end{array}$ & $\begin{array}{c}\gamma_{\mathrm{s}} \\
\left(\mathrm{KN} / \mathrm{m}^{3}\right)\end{array}$ & $\begin{array}{c}\gamma_{\mathrm{d}} \\
\left(\mathrm{KN} / \mathrm{m}^{3}\right)\end{array}$ & $\mathrm{e}_{0}$ & $\begin{array}{c}\mathrm{n} \\
(\%)\end{array}$ & $\begin{array}{c}\mathrm{Sr} \\
(\%)\end{array}$ & $\mathrm{B}$ \\
\hline $30^{\circ}$ & 150 & 10 & 5 & 196,35 & 3,44 & 16,02 & 17,52 & 26,70 & 15,10 & 0,77 & 43 & 56 & 0,98 \\
\hline $50^{\circ}$ & 150 & 9,83 & 5 & 193,01 & 3,43 & 14,91 & 17,75 & 26,70 & 15,44 & 0,73 & 42 & 55 & 0,98 \\
\hline $71,6^{\circ}$ & 150 & 10 & 5 & 196,35 & 3,37 & 11,75 & 17,17 & 26,70 & 15,36 & 0,74 & 42 & 43 & 0,98 \\
\hline $88^{\circ}$ & 150 & 10 & 5 & 196,35 & 3,45 & 13,21 & 17,58 & 26,70 & 15,52 & 0,72 & 42 & 49 & 0,98 \\
\hline $140^{\circ}$ & 150 & 10 & 5 & 196,35 & 3,51 & 13,63 & 17,88 & 26,70 & 15,74 & 0,70 & 41 & 52 & 0,98 \\
\hline
\end{tabular}

ANEXO 5 - Dimensões e índices físicos dos corpos de prova do solo residual jovem, submetidos aos ensaios de compressão triaxial com sucção controlada.

\begin{tabular}{|c|c|c|c|c|c|c|c|c|c|c|c|c|c|}
\hline $\begin{array}{r}u_{a}-u_{w} \\
(\mathrm{kPa})\end{array}$ & $\begin{array}{r}\sigma_{c}-u_{a} \\
(\mathrm{kPa})\end{array}$ & condição & $\begin{array}{c}\mathrm{H} \\
(\mathrm{cm})\end{array}$ & $\begin{array}{c}D \\
(\mathrm{~cm})\end{array}$ & $\begin{array}{c}\mathrm{V} \\
\left(\mathrm{cm}^{3}\right)\end{array}$ & $\begin{array}{c}\text { Peso } \\
(\mathrm{N})\end{array}$ & $\begin{array}{l}\text { w } \\
(\%)\end{array}$ & $\begin{array}{c}\gamma \\
\left(\mathrm{KN} / \mathrm{m}^{3}\right)\end{array}$ & $\begin{array}{c}\gamma_{\mathrm{s}} \\
\left(\mathrm{KN} / \mathrm{m}^{3}\right)\end{array}$ & $\begin{array}{c}\gamma_{\mathrm{d}} \\
\left(\mathrm{KN} / \mathrm{m}^{3}\right)\end{array}$ & $e_{0}$ & $\begin{array}{c}\mathrm{n} \\
(\%)\end{array}$ & $\begin{array}{c}\mathrm{Sr} \\
(\%)\end{array}$ \\
\hline 40 & 50 & 1 & 10,00 & 5,00 & 196,35 & 3,68 & 19,87 & 18,74 & 26,70 & 15,63 & 0,71 & 41 & 75 \\
\hline 40 & 50 & 2 & 10,00 & 5,00 & 196,35 & 3,77 & 22,67 & 19,17 & 26,70 & 15,63 & 0,71 & 41 & 85 \\
\hline 40 & 200 & 1 & 10,00 & 4,97 & 194,00 & 3,44 & 13,67 & 17,71 & 26,70 & 15,58 & 0,71 & 42 & 51 \\
\hline 40 & 200 & 2 & 10,00 & 4,97 & 194,00 & 3,70 & 22,40 & 19,07 & 26,70 & 15,58 & 0,71 & 42 & 84 \\
\hline 80 & 50 & 1 & 9,97 & 4,87 & 185,71 & 3,45 & 19,72 & 18,59 & 26,70 & 15,53 & 0,72 & 42 & 73 \\
\hline 80 & 50 & 2 & 9,97 & 4,87 & 185,71 & 3,46 & 19,96 & 18,63 & 26,70 & 15,53 & 0,72 & 42 & 74 \\
\hline 80 & 100 & 1 & 9,88 & 4,98 & 192,44 & 3,52 & 19,11 & 18,29 & 26,70 & 15,36 & 0,74 & 42 & 69 \\
\hline 80 & 100 & 2 & 9,88 & 4,98 & 192,44 & 3,54 & 19,92 & 18,42 & 26,70 & 15,36 & 0,74 & 42 & 72 \\
\hline 80 & 200 & 1 & 10,00 & 4,96 & 193,22 & 3,59 & 20,55 & 18,58 & 26,70 & 15,41 & 0,73 & 42 & 75 \\
\hline 80 & 200 & 2 & 10,00 & 4,96 & 193,22 & 3,58 & 20,05 & 18,50 & 26,70 & 15,41 & 0,73 & 42 & 73 \\
\hline 160 & 50 & 1 & 9,70 & 4,98 & 188,94 & 3,36 & 15,07 & 17,76 & 26,70 & 15,43 & 0,73 & 42 & 55 \\
\hline 160 & 50 & 2 & 9,70 & 4,98 & 188,94 & 3,40 & 16,61 & 18,00 & 26,70 & 15,43 & 0,73 & 42 & 61 \\
\hline 160 & 100 & 1 & 9,80 & 5,00 & 192,42 & 3,42 & 16,75 & 17,77 & 26,70 & 15,22 & 0,75 & 43 & 59 \\
\hline 160 & 100 & 2 & 9,80 & 5,00 & 192,42 & 3,43 & 17,13 & 17,83 & 26,70 & 15,22 & 0,75 & 43 & 61 \\
\hline 160 & 200 & 1 & 10,00 & 5,00 & 196,35 & 3,45 & 17,00 & 17,57 & 26,70 & 15,02 & 0,78 & 44 & 58 \\
\hline 160 & 200 & 2 & 10,00 & 5,00 & 196,35 & 3,46 & 17,00 & 17,62 & 26,70 & 15,06 & 0,77 & 44 & 59 \\
\hline 320 & 50 & 1 & 9,92 & 4,93 & 189,36 & 3,51 & 19,28 & 18,54 & 26,70 & 15,54 & 0,72 & 42 & 72 \\
\hline 320 & 50 & 2 & 9,92 & 4,93 & 189,36 & 3,34 & 13,47 & 17,64 & 26,70 & 15,54 & 0,72 & 42 & 50 \\
\hline 320 & 100 & 1 & 9,98 & 5,00 & 195,96 & 3,66 & 19,51 & 18,66 & 26,70 & 15,62 & 0,71 & 42 & 73 \\
\hline 320 & 100 & 2 & 9,98 & 5,00 & 195,96 & 3,46 & 13,17 & 17,67 & 26,70 & 15,62 & 0,71 & 42 & 50 \\
\hline 320 & 200 & 1 & 9,92 & 4,98 & 193,22 & 3,40 & 14,15 & 17,61 & 26,70 & 15,42 & 0,73 & 42 & 52 \\
\hline 320 & 200 & 2 & 9,92 & 4,98 & 193,22 & 3,37 & 12,94 & 17,42 & 26,70 & 15,42 & 0,73 & 42 & 47 \\
\hline
\end{tabular}

Obs: Condição 1 - após moldagem dos corpos de prova; Condição 2 - após imposição da sucção matricial nas câmaras da Figura 3.12. 
ANEXO 6 - Dimensões e índices físicos dos corpos de prova do solo residual maduro, submetidos aos ensaios de compressão triaxial com sucção controlada.

\begin{tabular}{|c|c|c|c|c|c|c|c|c|c|c|c|c|c|}
\hline $\begin{array}{c}\mathrm{u}_{\mathrm{a}}-\mathrm{u}_{\mathrm{w}} \\
(\mathrm{kPa})\end{array}$ & $\begin{array}{c}\sigma_{\mathrm{c}}-\mathrm{u}_{\mathrm{a}} \\
(\mathrm{kPa})\end{array}$ & condição & $\begin{array}{c}\mathrm{H} \\
(\mathrm{cm})\end{array}$ & $\begin{array}{c}\mathrm{D} \\
(\mathrm{cm})\end{array}$ & $\begin{array}{c}\mathrm{V} \\
\left(\mathrm{cm}^{3}\right)\end{array}$ & $\begin{array}{c}\text { Peso } \\
(\mathrm{N})\end{array}$ & $\begin{array}{c}\mathrm{w} \\
(\%)\end{array}$ & $\begin{array}{c}\gamma \\
\left(\mathrm{KN} / \mathrm{m}^{3}\right)\end{array}$ & $\begin{array}{c}\gamma_{\mathrm{s}} \\
\left(\mathrm{KN} / \mathrm{m}^{3}\right)\end{array}$ & $\begin{array}{c}\gamma_{\mathrm{d}} \\
\left(\mathrm{KN} / \mathrm{m}^{3}\right)\end{array}$ & $\mathrm{e}_{0}$ & $\begin{array}{c}\mathrm{n} \\
(\%)\end{array}$ & $\begin{array}{c}\mathrm{Sr} \\
(\%)\end{array}$ \\
\hline 40 & 50 & 1 & 9,95 & 4,95 & 191,48 & 3,26 & 30,36 & 17,03 & 27,20 & 13,06 & 1,08 & 52 & 76 \\
\hline 40 & 50 & 2 & 9,95 & 4,95 & 191,48 & 3,35 & 33,96 & 17,50 & 27,20 & 13,06 & 1,08 & 52 & 85 \\
\hline 40 & 200 & 1 & 9,94 & 5,00 & 195,17 & 3,40 & 34,00 & 17,42 & 27,20 & 13,00 & 1,09 & 52 & 85 \\
\hline 40 & 200 & 2 & 9,94 & 5,00 & 195,17 & 3,40 & 34,00 & 17,42 & 27,20 & 13,00 & 1,09 & 52 & 85 \\
\hline 80 & 50 & 1 & 10,00 & 5,00 & 196,35 & 3,42 & 34,70 & 17,42 & 27,20 & 12,93 & 1,10 & 52 & 86 \\
\hline 80 & 50 & 2 & 10,00 & 5,00 & 196,35 & 3,39 & 33,52 & 17,27 & 27,20 & 12,93 & 1,10 & 52 & 83 \\
\hline 80 & 200 & 1 & 9,90 & 4,90 & 186,69 & 3,25 & 34,61 & 17,41 & 27,20 & 12,93 & 1,10 & 52 & 85 \\
\hline 80 & 200 & 2 & 9,90 & 4,90 & 186,69 & 3,22 & 33,37 & 17,25 & 27,20 & 12,93 & 1,10 & 52 & 82 \\
\hline 160 & 50 & 1 & 10,00 & 4,99 & 195,56 & 3,40 & 33,00 & 17,39 & 27,20 & 13,07 & 1,08 & 52 & 83 \\
\hline 160 & 50 & 2 & 10,00 & 4,99 & 195,56 & 3,38 & 32,22 & 17,28 & 27,20 & 13,07 & 1,08 & 52 & 81 \\
\hline 160 & 200 & 1 & 10,00 & 4,97 & 194,00 & 3,32 & 30,48 & 17,11 & 27,20 & 13,12 & 1,07 & 52 & 77 \\
\hline 160 & 200 & 2 & 10,00 & 4,97 & 194,00 & 3,35 & 31,66 & 17,27 & 27,20 & 13,12 & 1,07 & 52 & 80 \\
\hline 320 & 50 & 1 & 9,95 & 5,00 & 195,37 & 3,33 & 30,08 & 17,04 & 27,20 & 13,10 & 1,08 & 52 & 76 \\
\hline 320 & 50 & 2 & 9,95 & 5,00 & 195,37 & 3,33 & 30,08 & 17,04 & 27,20 & 13,10 & 1,08 & 52 & 76 \\
\hline 320 & 200 & 1 & 9,95 & 5,00 & 195,37 & 3,33 & 30,87 & 17,04 & 27,20 & 13,02 & 1,09 & 52 & 77 \\
\hline 320 & 200 & 2 & 9,95 & 5,00 & 195,37 & 3,31 & 30,08 & 16,94 & 27,20 & 13,02 & 1,09 & 52 & 75 \\
\hline
\end{tabular}

Obs: Condição 1 - após moldagem dos corpos de prova; Condição 2 - após imposição da sucção matricial nas câmaras da Figura 3.12.

ANEXO 7 - Dimensões e índices físicos dos corpos de prova do solo residual jovem e maduro, submetidos aos ensaios de compressão hidrostática com sucção controlada.

\begin{tabular}{|c|c|c|c|c|c|c|c|c|c|c|c|c|c|}
\hline Solo & $\mathrm{U}_{\mathrm{a}}-\mathrm{u}_{\mathrm{w}}$ & condição & $\mathrm{H}$ & $\mathrm{D}$ & $\mathrm{V}$ & $\mathrm{Pes}$ & $\mathrm{w}$ & $\gamma$ & $\gamma_{\mathrm{s}}$ & $\gamma_{\mathrm{d}}$ & $\mathrm{e}_{0}$ & $\mathrm{n}$ & $\mathrm{Sr}$ \\
\hline & $(\mathrm{KPa})$ & & $(\mathrm{cm})$ & $(\mathrm{cm})$ & $\left(\mathrm{cm}^{3}\right)$ & $(\mathrm{N})$ & $(\%)$ & $\left(\mathrm{KN} / \mathrm{m}^{3}\right)$ & $\left(\mathrm{KN} / \mathrm{m}^{3}\right)$ & $\left(\mathrm{KN} / \mathrm{m}^{3}\right)$ & & $(\%)$ & $(\%)$ \\
\hline jovem & 80 & 1 & 9,8 & 5 & 192,42 & 3,52 & 19,11 & 18,29 & 26,70 & 15,36 & 0,74 & 42 & 69 \\
\hline jovem & 80 & 2 & 9,8 & 5 & 192,42 & 3,54 & 19,92 & 18,42 & 26,70 & 15,36 & 0,74 & 42 & 72 \\
\hline jovem & 160 & 1 & 9,8 & 5 & 192,42 & 3,42 & 16,75 & 17,77 & 26,70 & 15,22 & 0,75 & 43 & 59 \\
\hline jovem & 160 & 2 & 9,8 & 5 & 192,42 & 3,43 & 17,13 & 17,83 & 26,70 & 15,22 & 0,75 & 43 & 61 \\
\hline jovem & 320 & 1 & 9,95 & 5 & 195,37 & 3,66 & 19,51 & 18,72 & 26,70 & 15,66 & 0,70 & 41 & 74 \\
\hline jovem & 320 & 2 & 9,95 & 5 & 195,37 & 3,46 & 13,17 & 17,73 & 26,70 & 15,66 & 0,70 & 41 & 50 \\
\hline maduro & 80 & 1 & 10 & 5 & 196,35 & 3,44 & 34,00 & 17,52 & 27,20 & 13,07 & 1,08 & 52 & 86 \\
\hline maduro & 80 & 2 & 10 & 5 & 196,35 & 3,40 & 32,44 & 17,32 & 27,20 & 13,07 & 1,08 & 52 & 82 \\
\hline maduro & 160 & 1 & 10 & 5 & 194,78 & 3,32 & 30,48 & 17,04 & 27,20 & 13,06 & 1,08 & 52 & 77 \\
\hline maduro & 160 & 2 & 10 & 5 & 196,35 & 3,35 & 31,66 & 17,06 & 27,20 & 12,96 & 1,10 & 52 & 78 \\
\hline maduro & 320 & 1 & 10 & 5 & 196,35 & 3,33 & 30,87 & 16,96 & 27,20 & 12,96 & 1,10 & 52 & 76 \\
\hline maduro & 320 & 2 & 10 & 5 & 196,35 & 3,31 & 30,08 & 16,86 & 27,20 & 12,96 & 1,10 & 52 & 74 \\
\hline
\end{tabular}

Obs: Condição 1 - após moldagem dos corpos de prova; Condição 2 - após imposição da sucção matricial nas câmaras da Figura 3.12. 
ANEXO 8 - Dimensões e índices físicos dos corpos de prova do solo residual jovem, submetidos aos ensaios de compressão triaxial convencionais, secos ao ar e posteriormente cisalhados sem o controle da sucção.

\begin{tabular}{|c|c|c|c|c|c|c|c|c|c|c|c|c|}
\hline $\begin{array}{c}\sigma_{\mathrm{c}} \\
(\mathrm{kPa})\end{array}$ & condição & $\begin{array}{c}\mathrm{H} \\
(\mathrm{cm})\end{array}$ & $\begin{array}{c}\mathrm{D} \\
(\mathrm{cm})\end{array}$ & $\begin{array}{c}\mathrm{V} \\
\left(\mathrm{cm}^{3}\right)\end{array}$ & $\begin{array}{c}\text { Peso } \\
(\mathrm{N})\end{array}$ & $\begin{array}{c}\mathrm{W} \\
(\%)\end{array}$ & $\begin{array}{c}\gamma \\
\left(\mathrm{KN} / \mathrm{m}^{3}\right)\end{array}$ & $\begin{array}{c}\gamma_{\mathrm{s}} \\
\left(\mathrm{KN} / \mathrm{m}^{3}\right)\end{array}$ & $\begin{array}{c}\gamma_{\mathrm{d}} \\
\left(\mathrm{KN} / \mathrm{m}^{3}\right)\end{array}$ & $\begin{array}{c}\mathrm{e}_{0} \\
(\%)\end{array}$ & $\begin{array}{c}\mathrm{Sr} \\
(\%)\end{array}$ \\
\hline 50 & 1 & 9,97 & 5,00 & 195,76 & 3,68 & 19,87 & 18,79 & 26,70 & 15,68 & 0,70 & 41 & 75 \\
\hline 50 & 2 & 9,97 & 5,00 & 195,76 & 3,14 & 2,31 & 16,04 & 26,70 & 15,68 & 0,70 & 41 & 9 \\
\hline 100 & 1 & 10,00 & 5,00 & 196,35 & 3,44 & 13,67 & 17,49 & 26,70 & 15,39 & 0,73 & 42 & 50 \\
\hline 100 & 2 & 10,00 & 5,00 & 196,35 & 3,09 & 2,25 & 15,74 & 26,70 & 15,39 & 0,73 & 42 & 8 \\
\hline 200 & 1 & 9,97 & 4,87 & 185,71 & 3,45 & 19,72 & 18,59 & 26,70 & 15,53 & 0,72 & 42 & 73 \\
\hline 200 & 2 & 9,97 & 4,87 & 185,71 & 2,95 & 2,28 & 15,88 & 26,70 & 15,53 & 0,72 & 42 & 8 \\
\hline
\end{tabular}

Obs: Condição 1 - após moldagem dos corpos de prova; Condição 2 - após de secos ao ar. 